\title{
EXPERT MEETING
}

\section{OCCUPATION \\ AND OTHER FORMS \\ OF ADMINISTRATION \\ OF FOREIGN TERRITORY}




\section{EXPERT MEETING}

\section{OCCUPATION \\ AND OTHER FORMS

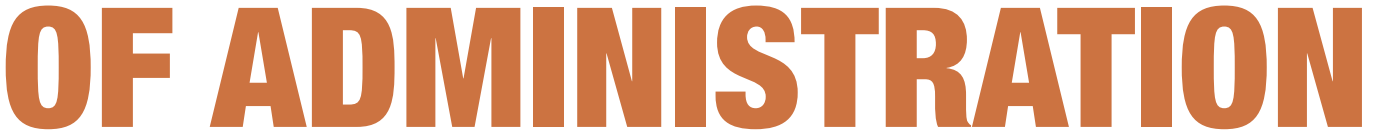 \\ OF FOREIGN TERRITORY}

Report prepared and edited by Tristan Ferraro Legal adviser, ICRC 


\section{CONTENTS}

\begin{tabular}{lr}
\hline FOREWORD & 4 \\
\hline ACKNOWLEDGEMENTS & 6 \\
\hline INTRODUCTION & 7 \\
\hline SUMIMARY & 10 \\
\hline FIRST MEETING OF EXPERTS: THE BEGINNING AND END OF OCCUPATION & 16 \\
PART ONE: THE BEGINNING OF OCCUPATION & 17 \\
A. THE PRESENCE OF FOREIGN FORCES: A NECESSITY FOR THE ESTABLISHMENT AND & 17 \\
MAINTENANCE OF OCCUPATION? & 19 \\
B. THE EXERCISE OF AUTHORITY BY FOREIGN FORCES & 20 \\
C. THE NON-CONSENSUAL NATURE OF BELLIGERENT OCCUPATION & 23 \\
D. THE CONCEPT OF INDIRECT EFFECTIVE CONTROL & 24 \\
E. DURATION AND GEOGRAPHICAL SCOPE OF OCCUPATION & 24 \\
F. THE LEGAL FRAMEWORK APPLICABLE TO THE INVASION PHASE &
\end{tabular}

PART TWO: THE END OF OCCUPATION 26

A. EVALUATING THE END OF OCCUPATION: A THORNY TASK

B. THE CRITERIA FOR DETERMINING THE END OF OCCUPATION

C. THE FUNCTIONAL APPLICATION OF OCCUPATION LAW AND THE NOTION OF

PART THREE: MULTINATIONAL OCCUPATION

A. THE APPLICABILITY OF OCCUPATION LAW TO UN OPERATIONS

B. OCCUPATION CONDUCTED BY A COALITION OF STATES

APPENDIX 1: BACKGROUND DOCUMENT BY PROF. MICHAEL BOTHE 36

APPENDIX 2: BACKGROUND DOCUMENT BY PROF. ADAM ROBERTS 41

APPENDIX 3: AGENDA AND GUIDING QUESTIONS AIMED AT FRAMING THE DISCUSSIONS 50

APPENDIX 4: LIST OF PARTICIPANTS

\begin{tabular}{ll}
\hline SECOND MEETING OF EXPERTS: DELIMITING THE RIGHTS AND DUTIES & \\
OF AN OCCUPYING POWER AND THE RELEVANCE OF OCCUPATION LAW & \\
FOR UN ADMINISTRATION OF TERRITORY & 54 \\
PART ONE: DELIMITING THE RIGHTS AND DUTIES OF AN OCCUPYING POWER & 56 \\
A. ARTICLE 43 OF THE HAGUE REGULATIONS OF 1907 AND ARTICLE 64 OF THE FOURTH & \\
GENEVA CONVENTION AS KEY PROVISIONS FOR ASSESSING THE SCOPE OF AN OCCUPYING & \\
POWER'S RIGHTS AND DUTIES & 56 \\
B. THE ROLE OF HUMAN RIGHTS LAW IN OCCUPIED TERRITORY & 61 \\
C. TRANSFORMATIVE OCCUPATION & 67 \\
D. PROLONGED OCCUPATION & 72
\end{tabular} 
PART TWO: THE RELEVANCE OF OCCUPATION LAW FOR UN ADMINISTRATION OF TERRITORY

A. THE DE JURE APPLICABILITY OF OCCUPATION LAW TO UN ADMINISTRATION

B. THE RELATIONSHIP BETWEEN OCCUPATION LAW AND THE SECURITY COUNCIL RESOLUTION ESTABLISHING THE INTERNATIONAL ADMINISTRATION

C. THE DE FACTO APPLICATION OF OCCUPATION LAW TO UN ADMINISTRATION

APPENDIX 1: BACKGROUND DOCUMENT BY DR SYLVAIN VITÉ

PART ONE: DELIMITING THE LEGAL FRAMEWORK APPLICABLE TO THE USE OF

FORCE IN OCCUPIED TERRITORY

A. DEFINING THE LEGAL REGIMES APPLICABLE

B. THEORIES AND CONDITIONS FOR DETERMINING THE LEGAL MODEL APPLICABLE

C. THE ROLE OF HUMAN RIGHTS LAW IN REGULATING THE USE OF FORCE IN OCCUPIED TERRITORY 116

D. THE ROLE OF OCCUPATION LAW IN REGULATING LAW ENFORCEMENT ACTIVITIES

PART TWO: THE APPLICATION OF THE 'CONDUCT-OF-HOSTILITIES' MODEL IN OCCUPIED TERRITORY

A. WHEN DOES THE 'CONDUCT-OF-HOSTILITIES' MODEL COME INTO PLAY?

B. THE LEGAL CLASSIFICATION OF HOSTILITIES ON OCCUPIED TERRITORY

C. DETERMINING THE LEGAL FRAMEWORK GOVERNING THE USE OF FORCE IN “GREY AREAS" 


\section{FOREWORD}

Occupation has been a recurring condition in the history of armed conflict. Belligerents have often resorted to the effective control of a foreign territory (or parts thereof) in order to subjugate their adversaries and achieve their objectives. Long-standing legal efforts to regulate these situations have produced the rules that now govern belligerent occupation and form an important area of international humanitarian law (IHL). In fact, belligerent occupation is regarded as a species of international armed conflict and treated as such by the relevant instruments of IHL, particularly the Hague Regulations of 1907 and the Geneva Conventions of 1949.

Occupation was initially perceived as being a matter of inter-State relationships. Based on the premise that occupation was a temporary situation neither causing nor implying any devolution of sovereignty, occupation law, as reflected in the Hague Regulations of 1907, was geared mainly towards preserving the interests of the occupied State and its institutions. It also presumed a state of peaceful coexistence between the occupant and the local population and insisted on the former involving itself as little as possible in managing the lives of those temporarily under its rule. Occupation law - in its early stages - was not aimed primarily at ensuring comprehensive protection for the individuals living under occupation; it concentrated on maintaining the sovereign rights of the ousted government until the conditions for its return were agreed upon by the belligerents.

Obviously, the nineteenth-century realities on which occupation law was based no longer exist. To an increasing degree, contemporary occupation is characterized by tensions between the occupying power and the local population (or at least some sections of the population), and by shifts in the role played by the occupying power in administering the occupied territory - which often means full-fledged exercise of foreign authority. As a result of these developments, people living under occupation have, increasingly, suffered the adverse consequences of occupation, which can be aggravated by the persistence of the situation.

The experiences of World War II prompted a number of important attempts, immediately after the end of the war, to improve the law by focusing attention on the welfare of those living under occupation. The need to enhance protection for these people became one of the main objectives of the Geneva Conventions of 1949, particularly the Fourth Geneva Convention "relative to the Protection of Civilian Persons in Time of War," which filled in the gaps in the law at the time. The Fourth Geneva Convention of 1949 and Protocol I of 8 June 1977 additional to the four Geneva Conventions provided for substantial development of the legal protection afforded by IHL to those living under occupation, notably by ensuring that their basic needs were met. IHL was adjusted with a view to incorporating the new realities of occupation, which required, more than in the past, attending to the preservation of the interests of the people under occupation.

This significant step in the evolution of the law - the advent of the Geneva Conventions of 1949 - notwithstanding, occupation law continues to face difficult challenges, as recent occupations have shown. In fact, occupying States have repeatedly contested the applicability of occupation law to situations of effective foreign control over territory, which clearly shows their reluctance to be labelled as occupying powers and/or to see their actions constrained by this body of law. This trend of denying the applicability of occupation law can be explained partly by the fact that the concept of occupation has a pejorative connotation and has often been characterized, usually by its critics, as "unlawful" and contrary to the overall objective of international peace and security set by the United Nations Charter. References to "unlawful occupation" can be misguiding, as they confuse the issue of the lawfulness of the resort to the use of force with that of the rules of conduct to be applied once armed force has been used, and therefore also obscure the fundamental distinction between jus ad bellum and jus in bello. Regarded from a purely IHL perspective, occupation law applies equally to all occupations, whether or not they are the result of force used lawfully within the jus ad bellum.

As the US military tribunal stated in the celebrated Hostages trial, "international law makes no distinction between a lawful and an unlawful occupant in dealing with the respective duties of occupant and population in occupied territory (...) Whether the invasion was lawful or criminal is not an important factor in the consideration of this subject." US Military Tribunals at Nuremberg, USA v. Wilhem List et al., Trials of War Criminals before the Nuremberg Military Tribunals Under Control Council Law No. 10, Vol. 11 (1950), p. 1247. 
Recent occupations have demonstrated that even when States consent to be bound by occupation law in the course of their military operations abroad, they sometimes take a self-serving approach to its application. Some States have even taken the view that occupation law cannot cope with the political, humanitarian and legal challenges created by contemporary occupation; they argue that these situations are very different from classical occupation and should be governed by rules that are more specific than those contained in occupation law at present.

The emergence of such views, particularly in the wake of the 2003 occupation of Iraq, has placed occupation law under considerable strain. Contemporary occupations have also raised a number of important legal questions directly of consequence for those living under or administering the occupation. These include questions related to the following issues: the beginning and end of occupation, the administration of occupied territories by coalitions, the occupying power's rights and duties, the use of force in occupied territory and the potential application of occupation law to the United Nations' administration of foreign territory. All these require more attention from the legal community.

On the basis of the issues listed above, as well as others that have recently posed a challenge to occupation law, ${ }^{2}$ the International Committee of the Red Cross (ICRC) concluded that it was necessary to analyse whether and how far the rules of occupation law might have to be reinforced, clarified or developed. For this reason, in 2007, it initiated a project on occupation law aimed at examining questions arising in connection with recent situations of occupation and other forms of administration of foreign territory. The project, which included consultations with key stakeholders and three meetings of experts, was intended as a follow-up to discussions held at a meeting of experts in 2003 on the applicability of IHL and occupation law to multinational peace operations.

This report, a major outcome of the ICRC project on occupation and other forms of administration of foreign territory, aims only to document the debates that took place during the three meetings of experts. It should also shed some light on the adequacy of occupation law in its present state. The conclusion that emerges from the ICRC project is that occupation law, because of its inherent flexibility, is sufficiently equipped to provide practical answers to most of the humanitarian challenges arising from contemporary occupations. Accordingly, it is the ICRC's view that occupation law does not require any further development at present; it requires only some clarification, by way of interpretations made in the spirit of the law that ensure that the needs of the occupied population are met and the security interests of the occupying power preserved at the same time.

The ICRC hopes that this report, which addresses only some selected, albeit fundamental, issues in relation to occupation and which does not represent the ICRC's legal positions on these issues, will contribute meaningfully to the task of clarifying some of the most significant issues and provisions of occupation law.

\section{Dr Knut Dörmann}

\section{Head of the Legal Division, ICRC}

Some of these issues were mentioned in the ICRC report submitted to the 28th and 30th International Conferences of the Red Cross and Red Crescent; the report was titled International Humanitarian Law and the Challenges of Contemporary Armed Conflicts. 


\section{ACKNOWLEDGEMENTS}

The present report is an official publication of the International Committee of the Red Cross (ICRC). It is the outcome of a project conducted by the ICRC from 2007 to 2011.

The conceptualization, drafting and publication of the report would not have been possible without the commitment and contributions of many individuals. Our personal gratitude goes, first of all, to the experts in their personal capacity, without whose commitment, expertise and clarification this expert process could not have been brought to a successful conclusion.

We would also like to express our thankfulness to Dr Tristan Ferraro, Legal Adviser in the ICRC's Legal Division, who was in charge of the project on occupation and other forms of administration of foreign territory and who prepared and edited this report.

Finally, we would like to sincerely thank all our colleagues at the ICRC who contributed to the text of the report through their comments, provided valuable support in the organization and follow-up of the expert meetings or helped with the publication of the report.

\section{Dr Knut Dörmann}

Head of the Legal Division, ICRC 
Recent years have seen a significant number of extraterritorial military interventions. In addition to the persistence of traditional forms of occupation, ${ }^{1}$ some of these interventions have given rise to new forms of foreign military presence on the territory of a State, sometimes consensual but very often imposed. These new forms of military presence have - to a certain extent - revived occupation law. Further, they have raised various legal questions, ${ }^{2}$ particularly in these four areas: determining the beginning and end of occupation; delimiting the rights and duties incumbent upon an occupying power; identifying precisely the legal framework governing the use of force in occupied territory; and assessing the relevance of the concept of occupation for the United Nations' administration of territory.

Determining the beginning and end of occupation: despite the fact that occupation law is a recognized branch of international humanitarian law (IHL), past practice demonstrates that most occupants have devised claims for the inapplicability of occupation law while maintaining effective control over a foreign territory or part thereof. This is evidence of States' reluctance to be perceived as occupying powers.

IHL instruments do not provide clear standards for determining when an occupation starts and when it ends. The definition of occupation is vague under IHL; in addition, other factors, such as the continuation of hostilities and the continued exercise of some degree of authority by local authorities, can also conspire to complicate the legal classification of a situation of occupation. This demonstrates the need for more precise guidance regarding when and how the law of occupation applies.

Delimiting the rights and duties incumbent upon an occupying power: it has become clear over the years that States often interpret occupation law's prescriptions in a self-serving way and with a view to reducing constraints on their discretionary powers. This trend might be suggestive of a pervasive scepticism about the relevance of occupation law to contemporary occupations.

In fact, occupation law has been challenged repeatedly on the basis that it is ill-suited for contemporary situations. Some States have attempted to justify their reluctance to accept the application of this body of law on the grounds that the situations in which they find themselves or in which they might find themselves differ considerably from the traditional concept of belligerent occupation. Therefore, they argue, current occupation law is not sufficiently equipped to cope with the particularities of the various kinds of occupation that now exist.

Recent occupations have prompted a great deal of commentary on occupation law's alleged failure to authorize the introduction of wholesale changes in the legal, political, institutional and economic structure of the territory under the effective control of a foreign power. It has been claimed that occupation law places an undue emphasis on preserving the continuity of the socio-political situation of the occupied territory. It has also been claimed that in fact, the transformation of an oppressive governmental system or the rebuilding of a society in complete collapse by means of occupation could be in the interests of the international community; and further, that such undertakings might even be necessary for the maintenance or restoration of international peace and security.

Occupation may be defined as the effective control of a foreign territory by hostile armed forces. This definition derives from Article 42 of the Hague Regulations of 1907, which states that "Territory is considered occupied when it is actually placed under the authority of the hostile army. The occupation extends only to the territory where such authority has been established and can be exercised." Thus, occupation is a factual situation, one regulated by IHL. Occupation law applies in all cases of total or partial occupation of foreign territory, whether or not the occupation meets with armed resistance. As a general rule, it provides the legal framework for the temporary exercise of authority by the occupant, striking a balance between the occupier's security needs and the interests of the ousted authority as well as those of the local population. Under occupation law, the sovereign title relating to the occupied territory does not pass to the occupant, who has, therefore, to preserve as far as possible the status quo ante. In other words, the occupying power must respect, as far as possible, the existing laws and institutions of the occupied territory. It is however authorized to make changes where necessary to ensure its own security and to uphold its duties under occupation law, particularly the obligation to restore and maintain public order and safety and the obligation to ensure orderly government in the areas concerned.

2 In its reports on "IHL and the challenges of contemporary armed conflicts" submitted on the occasion of the 28th and 30th International Conference of the Red Cross and Red Crescent, the International Committee of the Red Cross identified occupation as one of the subject matters raising challenges in the field of IHL, and the source, potentially, of a great deal of reflection and debate. See 28th International Conference of the Red Cross and Red Crescent, "IHL and the Challenges of Contemporary Armed Conflicts," September 2003, Doc. 03/IC/09, Pt. II, pp. 14-15; 30th International Conference of the Red Cross and Red Crescent, "IHL and the Challenges of Contemporary Armed Conflicts," October 2007, Doc. 30/IC/07/8.4, Pt VII, pp. 29-30. 
Thus, the far-reaching political and institutional changes undertaken in recent occupations have entailed an element of tension between occupation law's requirement to respect the laws and institutions in place and the perceived need to fundamentally alter the institutional, social or economic fabric of the occupied territory. To defuse this tension, it has been suggested that IHL should permit certain transformative processes and recognize the occupant's role in this respect. This raises the question of the restraints imposed by IHL on the occupant with regard to its rights and duties. Occupation law does not give carte blanche to the occupying power. However, contemporary interpretations of its rights and duties under this body of law are granting the occupying power a growing degree of latitude in the administration of the occupied territory. Therefore, limits to the manoeuvrability conferred on the occupying power need to be identified more clearly, particularly in cases of prolonged occupation.

Human rights law may also play an important role in delimiting the occupying power's rights and duties. Indeed, this body of law is widely recognized as applicable in situations of occupation, at least as regards certain types of activity. Consequently, human rights law may impose formal obligations relevant to the occupant; it is also widely regarded as a potential basis for altering existing local laws. Recently, the International Court of Justice (ICJ) affirmed the importance and relevance of human rights law in times of occupation and the occupant's legal obligation to take it into account while taking action and while developing policies in the occupied territory. ${ }^{3}$ Therefore, it is of the utmost importance to identify how, and to what extent, human rights law applies in occupied territory. From this perspective, the exploration of the legal interplay between human rights law and occupation law becomes essential, particularly in relation to matters where IHL is silent, vague or unclear.

The legal framework governing the use of force in occupied territory: another issue raised by recent instances of occupation relates to the identification of the legal framework governing the use of force by the occupying power. Occupation is often characterized by the continuation or resumption of hostilities between the occupying forces on the one hand and the armed forces of the occupied territory and/ or other organized armed groups more or less affiliated to the ousted government on the other. Force might also be used by the occupying power within the framework of its obligation to restore and maintain public order in the occupied territory. The simultaneous existence of these situations might result in confusion as to which legal model is applicable to the use of force in occupied territory. It is therefore necessary to clarify how the rules governing law enforcement and those regulating the conduct of hostilities interact in the context of an occupation.

The relevance of occupation law for UN administration of territory: in addition to the various challenges posed by contemporary occupations, a number of questions arise in relation to the applicability of occupation law to operations under the command and control of the United Nations (UN). The UN has sometimes, in the course of its operations, found itself having to assume certain governmental functions temporarily in lieu of the territorial sovereign. It is critical to determine whether occupation law is capable of being applicable to such operations, the precise conditions that must be fulfilled for its applicability, and, in case occupation law is deemed applicable, whether occupation by international organizations is subject to the same legal constraints imposed on individual States exercising effective control over foreign territory.

In fact, operations carried out under the auspices of the UN, such as those in Kosovo and East Timor, share many similarities with traditional military occupation. Consequently, where UN operations imply the international administration of a territory - particularly when the international authorities are vested with extensive executive and legislative powers - the rules governing occupation appear increasingly relevant. In this situation, IHL might provide practical solutions to many of the problems that arise and might direct the policies undertaken by the international administration. In any case, the applicability of IHL to internationally administered territories has to be delineated more precisely in the light of the specific nature and objectives of these operations.

Given the concerns mentioned above, the International Committee of the Red Cross (ICRC) concluded that the legal issues raised by contemporary forms of occupation had to be dealt with more thoroughly. Basing itself on what it had learnt during its operations, the ICRC decided that the four subjects mentioned above required further legal analysis.

(ICJ), Advisory Opinion on the Legal Consequences of the Construction of a Wall in the Occupied Palestinian Territory, 9 July $2004, \$ \$ 102$ et seq. ICJ, Armed Activities on the Territory of the Congo (Democratic Republic of the Congo v. Uganda), decision of 19 December 2005, § 178. 
These subjects have been at the core of the exploratory process - on occupation and other forms of administration of foreign territory - undertaken by the ICRC in 2008. Within this framework, three meetings of experts - involving representatives of States and international organizations, as well as participants from academic circles and NGOs - were organized in 2008 and 2009, with a view to addressing in more detail the legal issues raised by the subjects listed above. All the experts participated in their personal capacity; ${ }^{4}$ the meetings were held under the Chatham House Rule.

This report is not exhaustive; its aim is to furnish a faithful narrative of the main points discussed and positions expressed during these three meetings of experts on occupation and other forms of administration of foreign territory. It must be noted that the report does not reflect the ICRC's views on the subjects addressed at the meetings. ${ }^{5}$ It provides glimpses of the current state of debate on these subject matters. In this respect, the ICRC hopes that the report will contribute significantly to the clarification of some of the most important provisions of occupation law.

This document is divided in two parts. The first part summarizes the main results of the discussions among experts. The second part consists of a more detailed report by the ICRC of the proceedings of the three meetings. It also includes the agenda of each meeting, the list of the participants, and some experts' written contributions. 


\section{FIRST MEETING OF EXPERTS: THE BEGINNING AND END OF OCCUPATION}

\section{The beginning of occupation}

The experts discussed the cumulative constitutive elements of the notion of effective control over a foreign territory, which underpins the definition of occupation set out in Article 42 of the Hague Regulations of 1907.

The presence of foreign forces: this criterion was considered to be the only way to establish and exert firm control over a foreign territory. It was identified as a prerequisite for the establishment of an occupation, notably because it makes the link between the notion of effective control and the ability to fulfil the obligations incumbent upon the occupying power. It was also agreed that occupation could not be established or maintained solely through the exercise of power from beyond the boundaries of the occupied territory; a certain number of foreign "boots on the ground" were required.

The exercise of authority over the occupied territory: the experts agreed that, once enemy foreign forces were present, it was their ability to exert authority in the foreign territory that mattered, not the actual and concrete exercise of such authority. Using a test based on the ability to exert authority would prevent any attempt by the occupant to evade its duties under occupation law by deliberately not exercising authority or by installing a puppet government. It was also agreed that occupation law did not require authority to be exercised exclusively by the occupying power. It allows for authority to be shared by the occupant and the occupied government, provided the former continues to bear ultimate and overall responsibility for the occupied territory.

The non-consensual nature of belligerent occupation: absence of consent from the State whose territory is subject to the foreign forces' presence was identified as a precondition for the existence of a state of belligerent occupation. For occupation law to be inapplicable, this consent should be genuine, valid and explicit. The experts felt that because occupation law does not provide for any criteria for evaluating it, consent should be interpreted in the light of current public international law. Eventually, the existence of a presumption of absence of consent when foreign forces intervened in a failed State was approved.

With regard to the invasion phase, the experts almost without exception expressed their support for Pictet's theory as reflected in the ICRC's Commentary on the Fourth Geneva Convention (Article 6), according to which certain provisions of occupation law would be applicable during the invasion phase as a matter of law or policy. In relation to the practical application of Pictet's theory, it was stressed that only some provisions of occupation law would be applicable to the invasion phase. Discussions on the search for alternative protective frameworks led to the emergence of a consensus that Part III, Section I of the Fourth Geneva Convention - titled "Provisions common to the territories of the parties to the conflict and to occupied territories" - would apply as a matter of law to invasion, providing the civilian population in this area a certain minimum amount of protection.

The concept of indirect effective control: the theory of indirect effective control holds that a State may be considered an occupying power for the purposes of IHL when it enforces overall control over de facto local authorities or other organized groups that have effective control over a territory or part thereof. In the course of the discussions, this theory was met with approval.

It was also agreed that occupation could be limited geographically to very small places. However, the discussions on the time span necessary for acknowledging the establishment of effective control over a territory or part thereof revealed some divergence of opinion. 


\section{The end of occupation}

Determining precisely when an occupation had ended was deemed to be a very difficult task. However, it was emphasized that the legal criteria for establishing the end of an occupation should mirror those used for determining when it had begun. Therefore, the continued physical presence of foreign forces, their ability to exercise authority over the territory concerned in lieu of the territorial sovereign and the continued absence of the territorial sovereign's consent to the foreign forces' presence should, cumulatively, be studied when assessing the termination of occupation. Should any of these conditions cease to exist, the occupation ought to be regarded as having terminated. The discussions about the criteria for determining, for the purposes of IHL, the existence of a state of occupation took place with the idea of classical occupation in mind. During the debates, the possibility that the sui generis character of some situations may alter the criteria previously identified at the meeting was not discarded by some experts, particularly in terms of means to exercise effective control.

The presence of foreign forces: classical occupation presupposes the presence of a certain number of foreign troops in the occupied territory. It was felt that effective control could not usually be exercised without the continued physical presence of the foreign forces. Therefore, the absence of any hostile armed forces on the territory in question was thought to be a prerequisite for establishing that an occupation had ended.

The role of consent: it was agreed that genuine consent to the foreign presence could be given during the occupation and could mark its termination. In this respect, Article 47 of the Fourth Geneva Convention could not be interpreted as prohibiting the local government to give - over time - its consent to the foreign presence, thereby precluding the applicability of occupation law. The importance of assessing the end of occupation in the light of the actual situation was also emphasized. Where the actual situation remained unchanged - for example, if foreign forces continued to exert effective control over the foreign territory - the consent given by the local government would be meaningless and, ultimately, the occupation would endure.

The exercise of authority: the view according to which only a full transfer of powers and competences to the local authorities would end an occupation was found to have no basis in IHL. It was submitted that foreign troops could retain some competences over the foreign territory without necessarily being regarded as continuing the occupation. The discussions highlighted the need to identify a more precise legal framework for governing situations where foreign forces still exert some level of authority but not enough to qualify as effective control under IHL. With regard to the legal basis for residual responsibilities incumbent upon the former occupying power, opinion was split in two: one group of experts argued that remnants of authority would be governed by occupation law despite the absence of effective control for the purposes of IHL; the other group held that the residual responsibilities of the former occupant should be governed by other bodies of law such as human rights law.

\section{Multinational occupation}

It was agreed that occupation law could be applicable de jure to multinational operations, including those under UN command and control, provided the conditions for its applicability were met. It was argued that the criteria for assessing a state of occupation involving UN forces ought not to differ from those for more classical forms of occupation. The functional approach was deemed appropriate for identifying which countries participating in a coalition would be considered occupying powers for the purposes of IHL. Thus, the nature of a State's involvement in a multilateral occupation was regarded as a key factor in determining whether it was an occupying power. 


\section{SECOND MEETING OF EXPERTS: DELIMITING THE RIGHTS AND DUTIES OF AN OCCUPYING POWER AND THE RELEVANCE OF OCCUPATION LAW FOR UNITED NATIONS ADMINISTRATION OF TERRITORY}

\section{Delimiting the rights and duties of an occupying power}

The obligation to restore and ensure - as far as possible - public order and safety while respecting, unless absolutely prevented, the laws in force in the country: ${ }^{2}$ the participants emphasized the need to interpret this obligation broadly in order to allow the occupant to fulfil its duties under occupation law. A broad interpretation would be of particular assistance to the occupant in administering the occupied territory for the benefit of the local population while ensuring the security of its own armed forces. The experts took the view that this obligation did not grant the occupant the authority to enter into treaties on behalf of the occupied territory. They also pointed out that nothing under IHL would prevent the occupant from concluding treaties in its own name for the purposes of fulfilling its duties under occupation law.

The role of human rights law in occupied territory: the applicability of human rights law to situations amounting to occupation was accepted almost unanimously. The experts also felt that it would be useful to have a framework for interpretation in order to address the simultaneous application of human rights law and IHL. In this regard, it was affirmed that IHL was the lex specialis in situations of occupation. ${ }^{3}$ However, a majority of the experts argued that this did not definitively preclude the application of human rights law. They explained that it meant only that human rights law could not be applied in an unqualified manner; it should be applied in a manner that respects the balance set by the lex specialis between humanitarian considerations and military necessities. Conversely, it was also contended that IHL was not automatically the lex specialis in situations of occupation because the issue of its interrelationship with human rights law could not be settled by a general analysis of the two legal regimes. Instead, some experts suggested, the lex specialis ought to be determined by using a rule-by-rule or case-by-case approach.

Applying the International Covenant on Economic, Social and Cultural Rights (ICESCR) in occupied territory: Most of the experts shared the ICJ's view that foreign forces are bound by the ICESCR in exercising the powers available to them as an occupying power and that they should not impede implementation of the ICESCR's provisions in those fields where power has been transferred to the local authorities. The nature of the obligations enshrined in the ICESCR, as well as the flexibility given by the instrument for their implementation, was regarded by some experts as facilitating application of the ICESCR during occupation. It was argued nonetheless that the concept of progressive realization contained in the ICESCR, ${ }^{4}$ which epitomizes the flexibility of the instrument, should not be interpreted as an excuse for not implementing the core of each right. Citing the examples of the right to food and the right to health, some experts argued that the occupant's obligations were not limited to the minimum defined by IHL, but also encompassed the complementary contribution made by human rights law.

Transformative occupation: the concept of transformative occupation was defined as an operation, the main objective of which was to overhaul the institutional and political structure of the occupied territory, often to make it accord with the occupying power's own preferences. It was agreed that such occupation had no basis under current IHL, in particular because the transitory character of the rights and duties incumbent upon the foreign administrator precludes making definitive large-scale changes in the institutional structure of the occupied territory. However, a distinction was made between full-fledged transformative projects entailing disruptions of sovereignty and smoother changes aimed at getting the basic infrastructure of the occupied society to work in accordance with the relevant norms of occupation

2 Article 43 of the Hague Regulations of 1907. This provision, combined with Article 64 of the Fourth Geneva Convention, sets out the core duties incumbent upon the occupying power under IHL.

3 Lex specialis was defined as a principle according to which, in choosing between two rules, the one that was more specific and pertinent should be given precedence, since a special rule would usually give a clearer answer to the question at hand than a general one.

4 This concept of progressive realization is drawn from Article 2 of the ICESCR. In this provision, the ICESCR recognizes the differences in States' ability to fulfil the rights outlined in the covenant. The concept of "progressive realization" constitutes a recognition of the fact that it will generally not be possible to fully realize all economic, social and cultural rights in a short period of time. However, progressive realization should not be misinterpreted as depriving economic, social and cultural rights of all meaningful content. The purpose, rather, is to give governments flexibility in recognition of the differences in their economic state and their capabilities. It is not an escape clause. It includes the idea of continuous improvement and the obligation of the government to ensure that no regressive measures are taken. 
law. Compliance with the obligation to restore and maintain public order and civil life in occupied territory might call for some transformations and oblige the occupant to engage in important reforms. Five reasons that might justify transformation during occupation were put forward: respect for human rights law; consent of the local population; the particular characteristics of prolonged occupation; the case of occupied failed States; and decisions taken by the UN Security Council. ${ }^{5}$

Prolonged occupation: it was recognized that nothing under IHL would prevent occupying powers from embarking on long-term occupation. Occupation law would continue to provide the legal framework applicable in such cases. It was pointed out that prolonged occupation could affect the implementation of occupation law and special measures usually unnecessary during short-term occupation might be called for. Decisions related to the social, economic and, sometimes, political realms might need to be taken in order to maintain as normal a life as possible in the occupied territory. It was also agreed that the welfare of the local population should be established as the main principle guiding the measures and policies undertaken by the occupying power in the administration of the occupied territory. Decisions made by the occupying power should always respect the principles contained in the Hague Regulations and the Fourth Geneva Convention, which are flexible enough to accommodate most of the needs that arise during prolonged occupation. The need to set limits on the measures an occupying power may adopt to ensure the well-being of the local population was emphasized. To that end, it was suggested that the participation of the local population in decision-making could serve as a litmus test. External mechanisms of control could also be set up.

\section{The relevance of occupation law for UN administration of territory}

The de jure applicability of occupation law to UN administration: despite the potential dissonance between occupation law and the transformative purpose of the UN administration of territory, this corpus juris was identified as applicable de jure to UN administrations provided the criteria implied in Article 42 of the Hague Regulations were met.

The criterion of consent was regarded as a major hurdle for the de jure applicability of occupation law to UN administration of territory, since the UN, which generally seeks the consent of the host State, would not appear to be the "hostile" entity required by Article 42 of the Hague Regulations. The case of the UN administration of Kosovo illustrated how difficult making a concrete and objective evaluation of the consent criterion could be. The discussion about determining the criterion of consent revealed differences of opinion on the methods and means of interpreting the notion of consent, as well as on identifying the entity whose consent was required.

The relationship between occupation law and the Security Council resolution establishing the international administration: it was suggested that the Security Council would be entitled to determine whether a particular instance of consent to UN presence was valid, thus excluding the application of occupation law. However, this suggestion did not go uncontested: some participants rejected the idea that the Security Council could unilaterally exclude the application of occupation law merely by reclassifying a belligerent occupation as an international administration not subject to IHL, regardless of the prevailing facts. The possibility that the Security Council was permitted to act in this way was thought to contradict the core idea that the applicability of IHL depended on the prevailing facts, not on the legal classification of the situation in question.

The necessity of supplementing a Security Council resolution with rules taken from various relevant legal instruments was also emphasized. In this regard, a "default rule theory" was identified. This holds that since a UN mandate would never be sufficiently detailed to permit the precise identification of the rules applicable to the UN administration, it would be necessary to determine the default legal regime to be added to the Security Council's mandate. The default regime in turn would be determined by the legal criteria for determining whether a situation amounts to occupation, particularly by the criterion of absence of consent. When the UN administration is deployed with the consent of the host State, the default regime would be human rights law. Should the UN administration be deployed without the consent of the sovereign, occupation law would serve as the default regime supplementing the Security Council resolution setting out the UN mandate.

5 A majority of experts asserted that a Security Council resolution could, under certain circumstances, shape the provisions of occupation law that might be applicable. 
The de facto application of occupation law to UN administration: the possibility of applying occupation law by analogy - irrespective of whether it applied de jure - was also discussed. It was agreed that occupation law could offer practical guidance to the UN on matters such as the maintenance of public order and safety and the management of private and public property. Those who opposed this view said that human rights law provided a more appropriate legal framework, one that was more protective, and ought therefore to be the body of law that governed UN administration.

\section{THIRD MEETING OF EXPERTS: THE USE OF FORCE IN OCCUPIED TERRITORY}

\section{Delimiting the legal framework applicable to the use of force in occupied territory}

Defining the legal regimes applicable: three different legal regimes relevant for regulating the use of force in occupied territory were identified. The experts felt that IHL, in particular the rules governing occupation and those regulating the conduct of hostilities, would form a first set of legal provisions. Attention was also drawn to the importance of human rights law in relation to the use of force by the occupying power. However, there was some divergence of views regarding the extraterritorial reach of this body of law. Third, the relevance of the occupying power's domestic law was emphasized insofar as it played an important role in determining the occupying forces' armed response to a threat.

Theories and conditions for determining the legal model applicable: given the differences between the law enforcement and 'conduct-of-hostilities' models, it was deemed important to find ways of determining precisely when and how each of these would apply in occupied territory. The experts agreed that an approach that allowed for parallel application of both would be best.

The experts discussed criteria that would both justify the application of either model and the transition between them. Two trends emerged. The first one relates to a so-called "situation-based" or "sliding scale" approach. Under this approach, the choice and application of the model would be based on the actual situation prevailing at the time the occupying power decides to resort to force. This approach allows for a smooth transition between the two models based on the level of threat faced by the occupying power. The following considerations would be instrumental in determining when to shift from the law enforcement model to the 'conduct-of-hostilities' one in a specific situation: the nature of the threat faced by the occupying power and the differences in the level of control exerted by it, as well as the nature and duration of the occupation.

The second trend reflected the view that the transition between the law enforcement and conduct-ofhostilities models was not as straightforward as suggested by the "sliding scale" approach. In fact, a specific trigger was required to effect the shift from the law enforcement to the 'conduct-of-hostilities' model. Fulfilment of the criteria used to determine the existence of a non-international armed conflict was suggested as this trigger, which, under certain circumstances, would warrant application of the 'conduct-of-hostilities' model. Thus, the organization of the parties involved and the intensity of the armed confrontation would need to be examined: they would determine which model would apply when force was resorted to in occupied territory.

Finally, it was stressed that where the two models are applied simultaneously, law enforcement should be the default model. Therefore, except when the occupying power faces a threat that clearly originates in the armed forces of the occupied territory and/or affiliated armed groups, application of law enforcement rules and standards should be presumed.

The role of human rights law in regulating the use of force in occupied territory: a minority of participants emphasized human rights law's ability to regulate the use of force in all circumstances, including occupation. They said that the flexibility of the provisions of human rights law pertaining to the use of force would permit their application in almost all situations faced by the occupying power, ranging from the enforcement of the law against criminal acts such as robbery or drug trafficking to open hostilities pitting the occupying forces against insurgent armed groups. This position was contested on the basis that each body of law - IHL and human rights law - is designed for fundamentally different sets of circumstances. IHL aims to regulate the use of force in armed conflict while human rights law is intended primarily for peacetime. 
The role of occupation law in regulating law enforcement activities: some experts declared that it was necessary to dispel the misconception that occupation law per se could not provide a valuable legal framework for regulating the use of force in law enforcement operations. In fact, they said, the law enforcement model applied in occupied territory, as a matter not of human rights law but of occupation law as stipulated in key provisions of the Hague Regulations and the Fourth Geneva Convention. It was suggested that the combination of Article 43 of the Hague Regulations and Articles 27 and 64 of the Fourth Geneva Convention would constitute a workable legal framework for regulating the use of force in occupied territory. The interpretation and application of law enforcement standards in occupied territory was then discussed. In this regard, it was argued that law enforcement standards should be applied more liberally when occupying forces resorted to force during police operations. This position was challenged on the basis that any use of force by the occupying power in situations other than the conduct of hostilities remained subject to the law enforcement standards of precaution, proportionality and necessity similar to those deriving from human rights law.

\section{The application of the 'conduct-of-hostilities' model in occupied territory}

When does the 'conduct-of-hostilities' model come into play? It was claimed that occupation, per se, would not justify the use of this model without a clear manifestation of organized armed violence. A distinction was drawn between armed violence linked to the original international armed conflict and that emanating from armed groups not affiliated to the occupied State.

It was made clear that the occupying power would be entitled to use the 'conduct-of-hostilities' model when military force was used against the armed forces of the occupied State, affiliated militias or other resistance movements fulfilling the criteria of Article 4(A)(2) of the Third Geneva Convention, particularly if active hostilities persisted or had resumed within the framework of the original international armed conflict. However, it was pointed out that hostilities and other acts of violence directed towards the occupying power would usually emanate from organized armed groups not formally "belonging to" the occupied State within the meaning of IHL. The experts felt that IHL's response, when such armed groups not belonging to the occupied State carried out hostile activities in occupied territory, was not clear and necessitated clarification regarding when IHL rules on the conduct of hostilities would begin to apply. The threshold for determining the existence of a non-international armed conflict within the meaning of Article 3 common to the four Geneva Conventions was considered a workable test for determining when the 'conduct-of-hostilities' model would apply - to instances of force being used by the occupying power against organized armed groups not formally belonging to the occupied State.

The legal classification of hostilities on occupied territory: a distinction was made between armed confrontations pertaining to the original international armed conflict from which the occupation derived and those related to a "new" non-international armed conflict emerging alongside the occupation. It was agreed that, for the purposes of IHL, a non-international armed conflict could occur in conjunction with an occupation.

Finally, an attempt was made to determine the legal framework governing the use of force in operations that were both a police operation against individuals violating the laws in force in occupied territory (including measures promulgated by the occupying power) and a military operation against legitimate military targets under IHL. The participants were clearly divided on this question. Some claimed that the presumption of the law enforcement model's application would prevail; others were clearly inclined to promote the application of the 'conduct-of-hostilities' model as a matter of law. In the end, the majority of experts favoured the prevalence of the 'conduct-of-hostilities' model in such circumstances. 


\section{FIRST MEETING OF EXPERTS: THE BEGINNING AND END OF OCCUPATION 26-27 MAY 2008, GENEVA}

The applicability of occupation law has been compromised in a number of situations by the unwillingness of States to be perceived as occupying powers. In fact, past practice demonstrates - to a certain extent - the general reluctance of States to consider occupation law to be applicable, even when the criteria for its applicability seem, at first glance, to have been met. There are various explanations for this, notably: the pejorative connotation of the concept of occupation and the fact that acknowledgement of a state of occupation will necessarily trigger the application of the obligations set by occupation law restricting powers that an occupier will often regard as being discretionary.

Extraterritorial military operations raise a broad range of legal questions. However, the ICRC and other humanitarian organizations, as well as military actors, face the same crucial question at the outset: How should the situation on the ground be classified? In this respect, establishing clearly when a state of occupation begins and ends appears to be of the utmost importance in determining the nature and the extent of the belligerents' obligations and rights as well as the status and the fate of individuals under their control.

The concept of occupation has long been neglected in legal literature, but recent situations of occupation and the salient case of Iraq have renewed interest in occupation law. However, attention has been focused more on substantive rules of occupation than on issues raised by the establishment and termination of occupation. There has been relatively little interest in the standards used to determine the existence of a state of occupation. This is quite surprising since the question of whether an occupation has been established is central and must be dealt with before any substantive question of occupation law can be addressed.

IHL instruments do not provide a clear standard for determining whether a state of occupation exists. In fact, the criteria for occupation are described in very general terms; and ICRC experience shows that it is quite difficult to identify with precision the beginning and the end of an occupation. Definition is made more complicated by the differing characteristics of recent foreign military presence as well as by the means used by States in order to implement effective control of territories not their own. Adam Roberts put it rather well some time ago: "The core meaning of the term [occupation] is obvious enough, but as usually happens with abstract concepts, its frontiers are less clear."'

It is not always easy to determine when effective control over a foreign territory has been established, in particular when invasion has become occupation. The definition contained in Article 42 of the 1907 Hague Regulations is somewhat vague; and the situation may be further complicated by various factors, such as: the continuation of hostilities; the continued exercise of a degree of authority by the local government; geographical considerations or the invader's refusal to assume the obligations stemming from its effective control. Therefore, it is necessary to formulate more precisely the conditions whose fulfilment will define a state of occupation.

Another important issue concerns the law applicable during the invasion phase. The ICRC has always adopted a broad interpretation favouring the application of the Fourth Geneva Convention of 1949, with a view to maximizing legal protection for civilians. In this connection, the ICRC believes that efforts should be made to clarify the exact nature of the protection afforded by the law to civilians who are in the power of a belligerent, but are neither on a territory occupied by that belligerent nor on that belligerent's territory. The ICRC has identified this area of the law as raising important humanitarian concerns and deserving clarification. 
The end of occupation is also very difficult to determine. Progressive phasing out, partial withdrawal, retention of a certain amount of authority over areas previously subject to effective control and maintenance of military presence on the basis of consent that is perhaps not validly given: all these factors have complicated the task of legal classification and raised numerous questions about the termination of occupation.

Recent military operations have made it unambiguously clear that there is a need to define more precisely the legal criteria for identifying a state of occupation when multinational forces, sometimes operating under a Security Council mandate, are involved. Are the criteria for defining the beginning and end of occupation the same in this case? In a coalition, who are the occupying powers? For the purposes of IHL, are all the troops contributing countries considered occupants? Given the growing involvement of international organizations and coalitions of States in extraterritorial operations, these questions assume importance and deserve further legal clarification.

\section{Main points addressed during the meeting of experts}

\section{PART ONE: THE BEGINNING OF OCCUPATION}

In the introductory presentation, one expert set out the elements comprising effective control, which is at the heart of the concept of occupation. ${ }^{2}$ He stressed the importance, for the purposes of occupation law, of the cumulative criteria of military presence, potential exercise of authority and absence of the local authorities' consent. The discussions following the presentation focused on each of these elements. The notion of indirect effective control, and the temporal and geographical scope of occupation, were subjects of further debate. Finally, a working session was devoted to the legal framework applicable to the invasion phase preceding the establishment of occupation.

\section{A. THE PRESENCE OF FOREIGN FORCES: A NECESSITY FOR THE ESTABLISHMENT AND MAINTENANCE OF OCCUPATION?}

Military presence as an element of the 'effective control'3 test provoked constructive discussions among the experts. A majority of participants concluded very quickly that the presence of foreign armed forces in a disputed area was a prerequisite for the establishment of an occupation. However, one expert took a more nuanced approach, arguing that if military presence was a condition sine qua non for the establishment of an occupation, it would not necessarily be one for maintaining an occupation. The expert stressed that effective control, once it was established, could - to some degree - be exerted remotely. This view was challenged on the basis that the maintenance of an occupation would still necessitate a military presence on the ground, as an expression of continued effective control over the territory in question. Therefore, according to most of the experts, occupation could not be established or maintained solely through power exercised from beyond the boundaries of the occupied territory; it required a certain number of foreign boots on the ground, as it were.

The necessity of having troops on the ground was driven home by the clear rejection of the view that occupation could be enforced solely by either naval or air power. In addition, another point was stressed: control of air space did not by itself meet the requirement of 'effective control' for the purposes of IHL. Therefore, only effective control on land would characterize military occupation within the meaning of IHL. It was then specified that the prerequisite of having foreign troops on the ground did not mean that effective control required their presence on each square metre of the occupied territory. Referring to US Field Manual 27-10 (1956), one expert stressed that the size of the foreign forces could not be pre-determined and would vary according to the circumstances, in particular the topographical features of the territory, the density of the population or the degree of resistance encountered on the ground. Thus, in certain circumstances, an occupying power could exercise effective control by positioning its troops in strategic places of the occupied territory, enabling it to dispatch them fairly quickly to make its authority felt in the area concerned.

\footnotetext{
See Appendix 1 to the report.
}

3 The notion of "effective control" is not found in treaty law; it reflects an idea developed in the legal discourse pertaining to occupation to describe the circumstances and conditions under which one could determine the existence of a state of occupation under IHL. As such, effective control is reached when the three criteria derived from Article 42 of the Hague Regulations of 1907 - and discussed infra in the report - are fulfilled. 
Some experts also established a direct link between effective control and the presence of foreign forces on a contested area by underlining the relatedness of Article 42 of the Hague Regulations, which defines the concept of occupation, and Article 43 of the same instrument, which lays out the main obligations incumbent upon the occupying power (i.e. to restore and ensure public order and safety). These experts asserted that foreign forces present in a specific area could be regarded as occupying forces only if they were able to meet the obligations set forth under Article 43 of the Hague Regulations. It was also stressed that the link between effective control and the presence of foreign forces on contested territory stemmed from Article 41 of the Oxford Manual of 1880. Further, these experts noted that the concept of effective control would be meaningless if the occupying power was not in a position to fulfil its responsibilities under occupation law. This would eventually run counter to the principle of effectivity upon which the law of occupation was premised.

Another participant, while expressing support for the connection established between Articles 42 and 43 of the Hague Regulations, specified that the fulfilment of the duties incumbent upon the occupying power could only be incremental, as one could not expect an occupier to meet all its obligations as soon as it gained effective control over a territory. Making it necessary - for the purposes of IHL - for foreign troops to respect all their duties under occupation law as the starting point of occupation would therefore be unrealistic and would eventually expand the gap already existing between the invasion phase and the establishment of occupation, leading ultimately to a protection gap. The expert stressed that occupation required only a progressive realization of the occupier's duties and could exist even if an occupying power was not in position to meet all its obligations under occupation law. He concluded by declaring that this theory was supported by the fact that many of the provisions of occupation law were obligations of means, not of results.

Nevertheless, one participant disagreed with the connection made between the two Articles (42 and 43) of the Hague Regulations for the purposes of determining the existence of an occupation. He cast particular doubt on the fact that the applicability of Article 42 would depend on the enforcement of the duties set forth in Article 43, arguing instead that only the contrary was correct (that Article 42 conditioned the applicability of Article 43). According to this expert, mixing those two central provisions could result in requiring the foreign forces to concretely and effectively exert authority over the foreign territory ${ }^{4}$ and would therefore endanger the applicability of occupation law. This expert asserted that, in fact, a foreign force could still exert effective control even if it refused to fulfil its responsibilities under occupation law or if it let the local government administer the occupied territory. Unilateral refusal to meet the obligations arising from occupation law, whatever form that took, should therefore have no bearing on the classification of a situation as an occupation.

Another expert was reluctant to accept military presence as a condition sine qua non, regarding it as one element - among others - to factor into the classification exercise. For this expert, the key element of the 'effective control' test was interdiction/prevention of independent governmental authority. He asserted that occupation law obligations would take effect as soon as the foreign forces had deliberately eliminated the ability of the local authorities to carry out independently the functions of government. This view was vigorously contested by several experts who stated that the negative perspective of the test (prevention of the exercise of governmental functions) was per se not sufficient to establish an occupation. During that period, they said, occupation law would not be applicable since the interdiction of governmental functions, without replacement by the foreign forces' authority, would only lead to a vacuum of power and would not constitute occupation for the purposes of IHL. In fact, IHL would require another element, constituting the positive aspect of the 'effective control' test, i.e. the ability of the foreign forces to exert authority in lieu of the legitimate government. In this connection, some form of military presence would also be required in order to exert effective control over an area.

The experts also stressed that effective control could not be defined in reference to the general capabilities of the foreign forces as compared to those of their opponent. Rather, the test would refer to the effects of the foreign forces' presence on the exercise of authority in the contested area, in particular their specific ability to exert authority over the territory concerned in lieu of the legitimate government. In other words, most of the experts agreed that the test for an occupation should not be which of the belligerents had the military capability to impose their will, but rather which of them 
had the military capability by virtue of their presence in a given area to impose their authority and prevent their opponent from doing so, and eventually to be in effective control of that area.

In conclusion, almost all the experts agreed that military presence was a prerequisite for identifying the beginning of an occupation. Nonetheless, some of them also stressed that it could lose its relevance and apply in a nuanced manner for the end-of-occupation test. In this regard, some participants seemed to suggest that military presence would not be a condition sine qua non for determining the end of occupation.

\section{B. THE EXERCISE OF AUTHORITY BY FOREIGN FORCES}

Because of its importance in the occupation test, the notion of exercise of authority was discussed in depth by the participants. They identified three main issues of concern: the nature of the authority, the necessity - or otherwise - of substantiating such authority and the legal significance of the sharing of authority between the occupying power and local government.

A consensus developed quickly among the experts about the nature of the authority to be exercised by the occupying power. The experts agreed that "authority" should refer to the notion of governmental functions since occupation had to do with political direction of the territory concerned and could not be enforced by anything short of governmental control.

The discussions then turned to the ICJ's decision of December 2006 in the case of Democratic Republic of Congo (DRC) v. Uganda: the ICJ stated that occupation required the exercise of actual authority by the foreign forces (emphasis added). ${ }^{5}$ In others words, the ICJ decided that foreign troops should substantiate their authority in order to qualify as an occupying power. The experts unanimously expressed their disagreement with the test proposed by the ICJ, stating that such an interpretation would be too narrow and would not reflect lex lata. For the experts, the ICJ's judgment, by emphasizing actual over potential control, represented a significant change of course with regard to the interpretation and application of the test laid down in Article 42 of the Hague Regulations. The experts asserted that while the ICJ's focus on actual exercise of authority could introduce more certainty as to whether an area was occupied or not, it would also facilitate the creation of more legal black holes that would remain beyond the scope of responsibility of any authority, resulting ultimately in a protection gap for the individuals trapped in such areas.

Therefore, most of the experts supported a test based on the ability of enemy foreign forces to exert authority over a specific area. As illustration, one expert referred to the situation of Denmark during World War II when German armed forces, despite their military supremacy, had chosen not to exert authority and had let the Danish Government do so instead. Were the test proposed by the ICJ to be applied to this situation, Germany could not be said to have occupied Denmark. The experts also emphasized that the necessity to opt for a test based on the ability to exert authority was further supported by policy considerations. Indeed, the interpretation of Article 42 of the Hague Regulations disconnecting the existence of occupation from the actual and concrete exercise of governmental authority by the military power vis-à-vis the local population would eventually dissuade the occupying power from evading its obligation to govern the occupied territory. ${ }^{6}$ In addition, a test based on the ability to exert authority would prevent any attempt by the occupying power to evade its duties under occupation law through the installation of a government by proxy, which would exert governmental functions on its behalf.

Nonetheless, one expert expressed reluctance to rely on a test based on the ability to exert authority on the grounds that it would create uncertainty and could appear very abstract. He emphasized the necessity of having factual evidence that the occupying power was exerting some authority over the

5 ICJ, Armed Activities on the Territory of the Congo (Democratic Republic of the Congo v. Uganda), decision of 19 December 2005, $\$ 173$.

6 It was argued that requiring the foreign forces to concretely exercise authority (for instance, by establishing a provisional civil administration) would open the door to bad-faith interpretation of this criterion. Indeed, it would be enough for the occupier to refuse to assume its duties under the law in order to be seen as not actually exerting authority over the territory it had just invaded. Ultimately, such an approach could encourage the foreign forces to refrain from maintaining law and order or meeting the basic needs of the local population in order to not be seen as the occupying power. This would leave the local population without any protection since its own government would be incapable of governing the area and the foreign troops unwilling to do so. 
area in question. This was challenged by another expert, who asserted that the proposed test would need, not factual evidence for the exercise of authority (as one could imagine an occupying power giving free hand to the local government to administer the territory), but evidence that the opposite was not the case (i.e. successful challenges to the ultimate and overall authority of the foreign forces over the territory).

Eventually, the experts discussed the consequences of the sharing of authority in occupied territory. In this regard, one expert stated that occupation necessitated having exclusive and unique authority over the occupied territory. This was inferred, in particular, from Article 41 of the Oxford Manual of 1880 .

Other experts asserted that the rationale underlying the concept of occupation was partly this: the allocation of responsibilities between governments, which helped to fill the vacuum of authority that developed when a legitimate government had been displaced by force. In this regard, it was deemed important to identify who was the ultimate and overall bearer of responsibility in occupied territory. Once this had been determined, occupation law would allow for a vertical, but not a horizontal, sharing of authority. This vertical authority was implied, notably, by some provisions of the Fourth Geneva Convention of 1949 - in particular, Articles $6 \$ 3,47,50$ or 56 - requiring cooperation between the occupying power and national and local authorities. These experts argued that, fundamentally and most importantly, this power sharing should not affect the ultimate authority of the occupier over the occupied territory and should not impinge upon its security and military operations in the areas concerned. This vertical sharing of authority should derive from the occupying power's genuine will and not from its inability to displace the legitimate government and/or its surrogates. The continued operation of the legitimate government should be dependent on the occupier's willingness to let the former function and exert responsibilities. A distinction was also made between a situation in which military intervention had not settled the struggle to exert authority and one in which two sets of authorities were cooperating despite the military ascendancy of one over the other. In this regard, only the latter would reflect a relationship based on subordination and would therefore characterize a state of occupation. This view was supported by a majority of the experts.

\section{THE NON-CONSENSUAL NATURE OF BELLIGERENT OCCUPATION}

Given the classic distinction established by doctrine between belligerent and pacific occupation, the experts discussed at length the necessity - or otherwise - of ascertaining whether the presence of foreign forces was non-consensual in order to trigger the application of occupation law. Therefore, the debates focused on the issue of consent as a central element in the applicability of occupation law.

In this connection, one of the experts explained that his position on this issue had evolved over time. Having initially regarded the absence of consent as a prerequisite for the existence of occupation, he now considered it only one more element to factor into the 'occupation test.' He said that the applicability of occupation law should not ultimately depend only on the existence or absence of local authorities' consent to the foreign forces' presence. He also held that one had to distinguish between two functions of the notion of consent: consent for the mere presence of foreign forces and consent as a basis for the non-applicability of the occupation law regime. Under this theory, these functions should be kept separated so that consenting to the foreign troops' presence would not necessarily set aside the applicability of occupation law since this body of law could still serve a useful purpose in a situation of consensual foreign presence.

Another expert who supported this view stressed that the consent of local authorities should not change the entire context in which foreign troops operate and therefore the entire legal regime applicable. In such situations, the expert favoured the application of occupation law by analogy rather than de jure. In fact, this expert said, occupation law would be the only body of law capable of dealing with the triangle of interests (local government, local population and foreign forces) or conflict of interests resulting from the foreign forces' presence. Moreover, another expert added, the

It was explained that the vertical sharing of authority reflected the hierarchical relationship between the occupying power and the local authorities, the former maintaining a form of control over the latter through a top-down approach in the allocation of responsibilities. In contrast, the horizontal sharing of authority would imply a sort of competition between the foreign troops and the local authorities, which would ultimately raise questions about the ability of the former to impose its will on the latter, and consequently, for the purposes of IHL, about the existence of effective control. 
purposes for which consent was given by the host State could make occupation law pertinent and lead to its application by analogy. This would be the case particularly when consent was given with a view to delegating to the foreign forces the administration of a territory or part thereof.

These views were challenged by a majority of the experts who held that absence of consent was a central element and a precondition for establishing occupation. According to these experts, consent given by the host State would always result in the inapplicability of occupation law. One participant doubted whether a single example could be found of a situation being described as belligerent occupation - and consequently occupation law applied - after the host State's consent had been secured. However, most of the experts agreed that consent could play a subtler role in establishing the end of occupation.

The experts then discussed the characteristics of the notion of consent for the purposes of occupation law. In this connection, a majority of the experts were of the opinion that such consent should be genuine, valid and explicit for occupation law to be inapplicable.

The extreme difficulty of evaluating whether these various elements had been met was recognized. Some of the experts referred in particular to the concept of "engineered consent," defined as a process by which States intervening in a foreign territory would ensure, by any means or legal constructions available to them, that the presence of their armed forces would appear to have the consent of the host State. The examples of Panama and Czechoslovakia were mentioned in this connection. The experts specified that the notion of "engineered consent" was a means for these States to avoid being classified as occupying powers and tainted by the pejorative connotation of the term. Therefore, the concept of "engineered consent" made the task of assessing the authenticity, as well as the validity, of the consent a very thorny one. Nonetheless, most of the experts were of the view that the inherent complexity of interpreting the notion of consent would not detract from its overall importance in determining the applicability of occupation law. Most of these experts felt that the absence of consent should still be considered a precondition for occupation.

There was some divergence of opinion on interpreting the notion of coerced consent. In this connection, one expert referred to the extraterritorial military intervention in Haiti in 1994 and the Indonesian invasion of East Timor in 1975 as examples of coerced consent. Another participant challenged this, stating that those cases represented only a form of pressure that would not amount to coercion.

Taking the opportunity to comment on this very point, a large majority of the experts stressed that IHL and occupation law in particular did not constitute a self-contained regime and did not provide any criteria for evaluating consent. The experts said that the issue of consent should be interpreted in the light of current public international law, in particular by reference to the law of treaties, discarding a specific interpretation of the notion of consent for the purposes of occupation law. In this regard, it was noted that Article 52 of the Vienna Convention on the Law of Treaties states that a treaty was void only when a State had been coerced by the threat or use of force in violation of the principles of international law embodied in the UN Charter. Consequently, not every pressure or every threat or use of force would induce coerced consent. In others words, the threat or use of force in accordance with the UN Charter, resulting in a State consenting to the presence of foreign forces, could not lead to the application of occupation law.

Another expert, while supporting the interpretation of the notion of consent in the light of the law of treaties, asked what should happen when an agreement signed by foreign forces and a host State was in violation of the host State's domestic law. Should the Vienna Convention be used as the source of reference for addressing the question of consent, Article 46 of the Convention could be deemed applicable and could enable the occupied State to invalidate - under certain circumstances - any agreement signed in violation of its domestic law. In this connection, the expert expressed some doubts about the agreement negotiated between the United States and Iraq, since the procedures used were allegedly in violation of Iraqi constitutional law. The same expert also asserted that even when coerced consent is validated a posteriori by the Security Council, questions will remain concerning the applicability of occupation law. The expert referred to the examples mentioned above as "grey areas" that represented a form of unresolved consent. Some of the experts suggested that the applicability of occupation law should be presumed in such instances, that it should function as a default regime.The discussions then turned to the question of the validity of the consent. There were some differences of opinion: 
certain experts held that it was necessary that the consent to the foreign forces' presence be given by authorities legally entitled to do so under domestic law. According to this position, only the de jure government would be able to give its consent to the intervention of foreign troops.

One expert challenged this view, arguing that the consent should be given not by the de jure government, but by the de facto government effectively exercising authority over the territory concerned before the arrival of foreign military forces. This expert explained that a situation could be classified for the purposes of IHL only on the basis of the facts on the ground; and that this ultimately entailed determining who had de facto effective authority in order to identify which authority would be entitled to legitimize the foreign military presence.

Another expert asked what would happen when consent was given by a powerless de jure government and what legal framework of reference might apply in such a situation. Should the logic of the international political system prevail, consent given by an ineffective de jure government should be sufficient grounds for not classifying the situation as an occupation. Other experts argued that the principle of effectiveness underlying IHL and the related requirement to stick to the facts on the ground would necessitate applying occupation law when consent emanated from a powerless de jure government.

Another expert espoused a nuanced version of the latter view, arguing that it would be relevant only in situations where the de jure government had ceased to exist; the expert mentioned the situation prevailing in Afghanistan in 2001 as a case in point.

It was then affirmed that consent should always be explicit, to avoid the ambiguities attached to assessing consent given implicitly. The discussions that followed highlighted the necessity of distinguishing between absence of opposition to the foreign troops' presence and formal consent, the former not necessarily implying the latter and therefore not providing sufficient grounds for setting aside the application of occupation law. In the same vein, some experts mentioned that it was normal practice for States deploying troops abroad to sign an agreement with the host State, which would determine the legal framework applicable, rather than permit occupation law to be come applicable automatically. However, it was emphasized that the absence of a Status of Forces Agreement did not necessarily mean that the foreign forces' presence was not consensual or that occupation law should apply by default. It is entirely possible that the local government consented to the foreign troops' presence even when no such agreement had been signed. In this connection, the experts highlighted the necessity of considering situations on a case-by-case basis.

The difficulty of evaluating consent was also emphasized since consent was always the result of a political process that involved a balance of power. In this connection, all depended on the relative power of the States involved in the agreement. Consequently, an agreement made when the difference in power is great may not be genuine, but that does not mean that occupation law would necessarily apply. The experts underlined that it was very difficult to determine consent since, ultimately, its identification was mainly a political rather than a legal process.

Other experts underscored the importance of the Security Council's role as well as that of the international community in evaluating the genuineness and validity of consent. However, one expert expressed the necessity of nuancing the role of regional organizations in this regard, since they would always favour consent given by a de jure government over that provided by de facto authorities, these regional organizations generally being reluctant to accept the displacement of legitimate authorities by opposition groups.

The debates then focused on the issue of coerced consent being given legitimacy a posteriori by a Security Council resolution. The case of Kosovo served as a background for the discussions. One expert argued that the consent of the Republic of Yugoslavia in 1999 had been extorted and that the subsequent agreement authorizing the presence of foreign forces in Kosovo was null and void, therefore leading to the application of occupation law.

However, most of the experts were of the opinion that it would be very difficult to classify a situation as an occupation once consent - even if initially extorted by coercion - had been validated by the Security Council. Another expert argued that, irrespective of the notion of consent, only the mandate of the Security Council should matter for the purposes of defining the applicable law. Should 
the mandate of the Security Council require the deployment of foreign forces in a territory, in particular UN forces, the question of consent would become irrelevant since the Security Council resolution would be the only legal framework of reference.

Some experts challenged the latter view on the basis that it made no distinction between the functions mandated by the Security Council and the legal framework regulating those functions. It was also emphasized that, in general, Security Council resolutions did not provide any clear-cut indication of the applicable legal regime. In addition, another expert asserted that if a Security Council resolution did not expressly reject application of occupation law, this body of law might be relevant and applicable, should the conditions for its applicability be met.

One expert was emphatic that the Security Council could override IHL by virtue of Articles 25 and 103 of the UN Charter, but could not change definitions and concepts and declare that there was no occupation if the situation on the ground proved otherwise. However, another expert challenged this, stating that under public international law, the Security Council could do whatever it wanted, even twist the facts if it needed to.

The working session concluded with an exchange of views on the issue of consent in a situation that involved the deployment of foreign forces in a 'failed State.' One expert argued that lack of consent should be inferred from the absence of effective governmental authorities. He argued that occupation law would be the legal framework of reference for foreign forces, should the other, previously identified criteria be met. A consensus then developed among the experts that when foreign forces intervened in a 'failed State,' consent must be presumed to be absent; the experts also called for this view to be advocated.

\section{THE CONCEPT OF INDIRECT EFFECTIVE CONTROL}

While discussing the characteristics of the notion of effective control, one expert brought up the possibility of enforcing "indirect effective control" or "long-arm occupation." This means that a State would be an occupying power for the purposes of IHL when it enforced overall control over de facto local authorities or other organized groups that have effective control over a territory or part thereof. The situation in Nagorno-Karabakh was mentioned as an example of "long-arm occupation." The experts noted that if this definition were to be applied, the result would accord with the position stated by the UN General Assembly in various resolutions about Nagorno-Karabakh: it was considered to be territory occupied by Armenia.

However, one expert expressed some concern about the concept of indirect effective control, fearing that it would overstrech IHL. He said that some element of foreign origin - an invasion by foreign forces, for instance - was necessary in order to classify a situation as an occupation and to trigger the applicability of occupation law. This expert rejected the possibility of occupation occurring indirectly, especially through the local population or other local elements.

This view was then contested by some experts, who expressed support for the theory of indirect control. They argued, notably, that occupation could be exerted through local armed groups enlisted by a foreign army, who would be acting as de facto agents of another State and would therefore be fulfilling the requirement of foreign involvement. This position has been endorsed by the International Criminal Tribunal for the former Yugoslavia in its jurisprudence ${ }^{8}$ and is implied by the ICJ in the case of Democratic Republic of the Congo v. Uganda. ${ }^{9}$

The expert who had challenged the relevance of indirect effective control then retreated from his original position, explaining that his reluctance to accept the concept was based on his scepticism about the notion of overall control rather than about occupation achieved through de facto local agents. The experts eventually agreed that occupation could take the form of overall control exerted by a foreign State over local authorities who had effective control of a territory.

8 ICTY, Prosecutor v. D. Tadic, Trial Chamber, judgment 7 May 1997, case IT-94-1-T, $\$ 584$; ICTY, Prosecutor v. Blaskic, Trial Chamber, judgment 3 March 2000, case IT-95-14-T, \$149-150; ICTY, Prosecutor v. I. Rajic, 13.09.1996, Review of the Indictment Pursuant to Rule 61 of the Rules of Procedure and Evidence, $₫ 40 \mathrm{ff}$.

9 ICJ, Armed Activities on the Territory of the Congo (Democratic Republic of the Congo v. Uganda), decision of 19 December 2005 $\S 177$. 


\section{E. DURATION AND GEOGRAPHICAL SCOPE OF OCCUPATION}

The experts unanimously agreed that occupation could be limited to very small places (villages or small islands were mentioned in this respect) because Article 42 of the Hague Regulations does not limit the geographical scope of occupation. However, one expert said that in certain circumstances - particularly, situations of partial occupation - delimiting the exact "boundaries" of the occupied territory might prove to be extremely complicated; the difficulties encountered by the ICJ in setting the territorial limits of the Ugandan occupation of the Democratic Republic of the Congo was emblematic in this respect.

However, the subject of duration created important differences of opinion among the experts. One expert held that occupation implied some degree of stability in the area subject to the foreign forces' intervention. Therefore, a certain period of time (two weeks were mentioned) would be necessary to evaluate whether a territory had been taken over firmly by foreign forces and was under occupation. These two weeks would be the least amount of time for the occupying power to demonstrate effective control over the territory concerned and assume its responsibilities under IHL. The expert concluded by saying that it would be very difficult to distinguish in less than two weeks, occupation from mere raids or the passage of 'flying columns.'

Noting that it would be almost impossible to fix precisely when invasion becomes occupation, some experts said that occupation law did not set specific time limits for occupation and was, in fact, mute on the subject of minimum duration. They said that occupation could be very short, a few hours or a couple of days. In this connection, the jurisprudence of the Eritrea-Ethiopia Claims Commission, which fixed the minimum period for occupation (a few days), was mentioned. ${ }^{10}$ One expert accepted the concept of episodic occupation and said, in justification of it, that IHL did not require the occupying power to be able to meet all the responsibilities assigned to it by occupation law in order to establish an occupation. Occupation law should be implemented gradually over time. In this respect, one could imagine a very short occupation in which the occupying power would have only limited responsibilities, those that it would be able to meet. This expert held that this view was fortified by the fact that most of the positive obligations incumbent upon an occupying power were obligations of means, not of results.

\section{F. THE LEGAL FRAMEWORK APPLICABLE TO THE INVASION PHASE}

The difficulty of drawing a precise distinction between extended incursions and the establishment of occupation led the experts to discuss the legal framework applicable to the invasion phase. Emphasis was placed on the necessity and/or the usefulness of applying some provisions of occupation law to the invasion phase even when, legally speaking, the foreign forces did not have effective control of the area in question. Some experts underlined the importance of providing legal protection for the civilian population in areas where the territorial State was no longer capable of enforcing its authority because of the military operations carried out by the foreign forces, but where the latter had not yet achieved effective control.

A lengthy of discussion of the so-called "Pictet theory" followed. This theory holds that the word "occupation," as used in the Fourth Geneva Convention, would have a broader meaning there than in Article 42 of the Hague Regulations. As far as individuals are concerned, the applicability of the Fourth Geneva Convention would not depend on the existence of a state of occupation within the meaning of the Hague Regulations, the latter being based on a territorial approach to occupation; it would begin as soon as the foreign forces came into contact with the civilian population of the territory being invaded. Therefore, relations between the advancing foreign troops and the civilian population would be governed by the Fourth Geneva Convention, including the protective provisions set out in its Part III, Section III on occupied territories. ${ }^{11}$

Although some experts underlined the difficulty of identifying with exactness the "Pictet theory"'s legal basis, the vast majority of participants showed some empathy for the application of the Fourth

10 Eritrea Ethiopia Claims Commission, Partial Award, Western Front, Aerial Bombardments, and Related Claims, Eritrea Claims, 1, 3, 5, 9-13, 14, 21, 25,26, \$26-27.

11 Commentary, Convention (IV) relative to the Protection of Civilian Persons in Time of War, ICRC, Geneva, 1958 , p. 60. 
Geneva Convention across the board and favoured its application in situations of invasion as a matter of law or policy.

Indeed, those in favour of it argued that such a broad interpretation of the concept of occupation, one that would include the invasion phase, was necessary in order to avoid protection gaps, ${ }^{12}$ and was the only legal construction that would ensure that the basic needs of the civilian population were met. Choosing another interpretation would have absurd results: individuals meeting the definition of 'protected person' within the meaning of Article 4 of the Fourth Geneva Convention would not benefit from substantial provisions of this instrument. In this regard, it was asserted that the "Pictet theory" would be the only one meeting the requirements of a teleological interpretation of the Fourth Geneva Convention. In this regard, too, a majority of the experts held that the obligations contained in Part III, Section III of the Fourth Geneva Convention (titled "Occupied territories") would apply, to a certain extent, to the invasion phase. In other words, the applicability of the Fourth Geneva Convention during the invasion phase would be based on effective control over persons rather than on effective control over foreign territory (or parts of it).

Should the majority opinion favouring the application of the "Pictet theory" prevail, its scope would have to be defined: Would occupation law apply fully to the invasion phase or would it do so only partially? Interestingly, no expert suggested that occupation law would be fully applicable during the invasion phase. There was no consensus among the experts on a detailed list of rules to be respected by the advancing forces. However, they tried to identify sets of paired rights and obligations that would have to be respected during an invasion: individual-related rights vs governance-related norms as well as positive vs negative obligations. According to these proposals, negative obligations and individual-related rights would apply immediately during the invasion phase while positive obligations and governance-related norms would take effect gradually. ${ }^{13}$ The fulfilment of positive and governance-related duties would be based on the level of control exerted, the constraints prevailing in a situation of invasion, and the resources at the foreign forces' disposal.

However, two experts openly challenged the legal basis of the "Pictet theory." They exploited the structure of the Fourth Geneva Convention to restrict the application of occupation law to situations in which foreign forces exerted effective control over a given territory. They said that the fact that an entire section of that instrument was devoted specifically to "occupied territory" would point towards rejection of the application of occupation law during the invasion phase. ${ }^{14}$ They said also that the "Pictet theory" would conflate identification of protected persons with determination of occupation as well, because it did not recognize that the Fourth Geneva Convention contained provisions that were specific to occupied territories and enforceable only in situations of effective control. These experts also stressed the fact that occupation law was a situation-based body of law and that the "Pictet theory" would deny the territorial dimension of the concept of occupation. Some experts disputed the relevance of the "Pictet theory" on the basis that it could lead to a selective approach to the applicability of occupation norms during invasion, which could ultimately prove detrimental to the understanding and integrity of IHL.

Those who opposed the "Pictet theory" said that it could also be challenged on the basis that it ignored the prevailing facts on the ground, particularly the fact that there was very often a break between the invasion phase and the realization of effective control. It would therefore be wrong to state that there was no intervening period between these two phases of the military operation

2 This would be the case especially if one takes the position that there is always an interval between the invasion phase and the stabilization of occupation. Unless the concept of occupation is broadly interpreted, individuals stuck in territories invaded but not yet occupied would benefit only from the limited protections set out in Parts I and II of the Fourth Geneva Convention.

13 It should be noted that an expert who favoured the immediate application of individual-related rights provided by the Fourth Geneva Convention nonetheless questioned whether Article 49 of that instrument would fall into this category.

14 These experts also asserted that the lack of connection between the application of occupation norms and the notion of effective control established by those supporting the "Pictet theory" would eventually put the lex specialis character of occupation law at risk. By detaching occupation law from its factual foundations, the "Pictet theory" made it impossible for the some of the fundamental provisions of this body of law to be implemented. Indeed, the experts deemed that most provisions of occupation law required the existence of effective control in order to be fully respected. By dissociating the applicability of the law of occupation from the concept of effective control, the "Pictet theory" enabled the creation of a situation in which foreign troops would not be able to meet their legal obligations under occupation law. This would ultimately contribute to the erosion of occupation law's relevance, as that body of law would no longer be capable of producing legal effects or of responding adequately to the social needs arising from a given situation. 
conducted by the invading troops, as the commentaries to the Fourth Geneva Convention do. ${ }^{15}$ The "Pictet theory" would detach the legal analysis under IHL from its factual foundation and ultimately stretch occupation law to the point where the principle of effectivity underpinning it would be nullified.

Another expert, who also challenged the applicability of occupation law to the invasion phase, declared that the "Pictet theory" had never found support in practice. As illustration, he cited the most recent edition (2004) of the United Kingdom's Manual of the Law of Armed Conflict, from which every mention of the "Pictet theory" had been expressly removed. ${ }^{16}$

However, some of the experts rejected the idea that the "Pictet theory" had never had any legal strength or reach. They pointed out that in fact the International Criminal Tribunal for the former Yugoslavia ${ }^{17}$ had expressly endorsed the "Pictet theory" in the Naletilic case, demonstrating the emergence of an opinio juris in this regard.

It was eventually mentioned that the lack of an alternative legal regime for protecting the civilian population during the invasion phase was not sufficient reason for inferring that occupation law would apply by default. Such an argument was described as being far-fetched. Indeed, some experts suggested that alternative regimes, in particular human rights law, should be considered for the purpose of protecting civilians in contact with the invading troops.

During the discussions about searching for alternative solutions, a consensus emerged among the experts about the applicability of Part III, Section I of the Fourth Geneva Convention, titled "Provisions common to the territories of the parties to the conflict and to occupied territories," which would provide a minimum framework of protection for civilians trapped in the invaded areas. According to some experts, the use of the plural form in the title of that section ${ }^{18}$ would imply for the foreign forces an obligation to respect the obligations set out in Articles 27 to 34 of the Fourth Geneva Convention, not only in their own territory but also while they were invading enemy territory. One expert also declared that Part III, Section I would be complemented by the applicability of Article 75 of Protocol I of 8 June 1977 additional to the Geneva Conventions, reflecting customary international law: this combination would afford a web of legal protection in situations of invasion and enable the basic needs of the civilian population remaining in those areas to be met. Finally, one participant said that the same result (meeting the civilian population's basic needs) would be achieved through the application of fundamental IHL principles as well, by virtue of the Martens Clause.

\section{PART TWO: THE END OF OCCUPATION}

The second day of the meeting was devoted to issues related to the end of occupation and effective control enforced by multinational forces.

One expert made an introductory presentation in which he laid the groundwork for further discussion by drawing attention to the key issues. He highlighted the specific difficulties associated with determining the end of occupation; wondered whether the criteria for doing so were identical to those for determining the beginning of occupation; looked for rules governing situations in which elements of foreign administration still endured despite the phasing out of foreign forces; and, finally, considered the applicability of occupation law to multinational operations.

The presentation was followed by in-depth and fruitful discussions on the end of occupation as well as on the conditions for applying occupation law to multinational operations.

15 Commentary, Convention (IV) relative to the Protection of Civilian Persons in Time of War, ICRC, Geneva, 1958, Commentary to Article 6, pp. 59-61.

16 UK Ministry of Defence, The Manual of the Law of Armed Conflict, 2004.

17 ICTY Prosecutor v. M. Naletilic \& V. Martinovic, Judgment, Case IT-98-34-T, Trial Chamber, 31 March 2003, \$218.

18 "Territories of the parties to the conflict" and not "territory of a party to the conflict," as referred to in Part III, Section II of the Fourth Geneva Convention. 


\section{A. EVALUATING THE END OF OCCUPATION: A THORNY TASK}

A consensus quickly developed about the difficulty of determining precisely when an occupation has ended. The participants pinpointed the near impossibility of identifying a precise date for the end of an occupation since it - the end of occupation - can be a slow process of change, usually characterized by the gradual phasing out of foreign forces from the occupied territory. The variety of forms that the end of occupation could take ${ }^{19}$ also further complicated its assessment as well as the identification of the legal framework applicable in such circumstances.

The experts stressed that this difficulty in making assessments could be explained in part by occupying States resorting to bogus endings of occupation: they try to circumvent the facts on the ground by devising shaky legal constructions for asserting that the occupation had ended, despite their continuing presence in the areas concerned. In this regard, one expert proposed a distinction between a factual and a "notional" end of occupation, the latter corresponding to a formal recognition - notably through a statement made by the foreign troops' government or through a Security Council resolution - even when the situation had not radically changed (e.g. the foreign forces continued to exert effective control over the territory). This expert cited Security Council Resolution 1546 on Iraq as an example of such a "notional" end of occupation. Another participant proposed a distinction between a de facto and a de jure end of occupation, the latter being based on a binding decision, in particular by the Security Council. A majority of experts took the view that it was difficult to oppose a Security Council resolution stating that a particular occupation had ended by virtue of the cumulative application of Articles 25 and 103 of the UN Charter, even if that resolution did not reflect the reality on the ground.

Nonetheless, some experts challenged this position. They declared that even though a Security Council resolution could change, within the limits posited by public international law, the content of the legal framework applicable to a specific situation, it could not alter definitions and concepts on which a whole body of law - and the related protections - was based. They also asserted that the Security Council could not twist the reality by stating that an occupation had ended when the facts on the ground said otherwise, insofar as IHL applicability was always based on the factual situation prevailing at the time of the legal classification. Another expert supported this view, adding that insofar as occupation law consisted incontrovertibly of jus cogens norms, ${ }^{20}$ the rule defining the concept of occupation ${ }^{21}$ and resulting in the application of those peremptory norms should also be vested with the same legal status. Consequently, a Security Council resolution has to respect the integrity of Article 42 of the Hague Regulations - interpreted as a jus cogens norm per se - and cannot declare an occupation to have ended if the conditions set out in that norm have not yet been met.

These discussions highlighted the need for procedures by which the end of an occupation could be assessed with more objectivity. To that end, some experts emphasized the role that the Security Council, certain regional organizations and the ICJ could play in this regard. However, one expert said that too much emphasis should not be placed on the positions adopted by international organizations since they could be biased. Citing the recent occupation of Iraq by coalition forces, he pointed out that occupants might in some instances be able to substantially influence the positions taken by some of these organizations since they - the occupying powers - were also State members thereof and involved in the decision-making process of these organizations.

In that context, the importance of declarations made by former occupying States was underscored. While recognizing that such statements might be indicative of a factual situation, the majority of the participants regarded them as not being constitutive. According to a few experts, the fact that Israel styled itself as no longer being the occupying power in the Gaza Strip should not result in the inapplicability of occupation law in that territory since the situation on the ground proved that the area was still under effective Israeli control..$^{22}$ Taking into account the reluctance of States to admit

19 Such as progressive phasing out, partial withdrawal, retention of a certain amount of authority over areas previously subject to effective control and maintenance of military presence on the basis of consent that is perhaps not valid.

20 Two experts nevertheless held that occupation did not include jus cogens norms.

21 The expert was referring to Article 42 of the Hague Regulations of 1907.

22 This characterization of the situation in the Gaza Strip was not supported by other experts. Furthermore, it should be borne in mind that the purpose of the discussions was not to consider the legal status of the Gaza Strip for the purposes of IHL. Nor was it the case for any other situation. 
that they occupy or continue to occupy a foreign territory, the experts thought that such declarations could represent only a rebuttable presumption that occupation law would not apply any more and should, in any case, be substantiated by drastic changes in the prevailing situation.

Finally, a majority of the experts declared that the difficulties associated with assessing an occupation were largely due to the pejorative connotation of 'occupation.' Some participants felt that there was a need to replace the term with one that was less "offensive," with a view to making IHL rules more acceptable for States concerned about the political consequences of being perceived to be occupying a foreign territory. In this regard, the necessity of dissociating the label from the related legal framework was underlined. In fact, some of the States who seemed to be most apprehensive about being associated with the concept of occupation per se expressed much less concern about the substantial provisions of occupation law. In this respect, it appeared to some experts (though not all) of the utmost importance to change the existing terminology in order to make sure that the protection afforded by occupation law would not be affected by the pejorative connotation of occupation. Concepts such as effective control or extraterritorial administrative responsibilities were proposed as potential alternatives.

\section{B. THE CRITERIA FOR DETERMINING THE END OF OCCUPATION}

After a preliminary exchange of views on the difficulty of identifying the end of occupation, the experts went on to discuss the criteria to be used to this effect.

A large majority of the experts expressed the view that the criteria for establishing the end of an occupation should mirror the ones used to determine its beginning. In other words, the criteria should be the same as those for the beginning of occupation but in the reverse order. Therefore, the physical presence of foreign forces, their ability to exert their authority over the territory concerned and the continuing absence of the territorial authorities' consent to the foreign forces' presence would be the preconditions that would have to be cumulatively fulfilled in order to conclude that the occupation had not ended. Should one of those criteria be unmet, it would result in the termination of the state of occupation. The concept of 'classic' occupation was the basis of the discussions on the criteria for determining the existence of a state of occupation, in particular its termination, for the purposes of IHL. ${ }^{23}$

The position taken by the experts was quite surprising: during the discussions about the beginning of occupation some experts had held that the criteria for assessing the beginning and end of occupation could differ to a certain extent, in particular the criterion relating to foreign military presence. The discussions revealed that one important explanation for this reversal of opinion lay in the mistake often made of confusing the various ways by which an occupation could be terminated with the legal criteria used to classify the situation. The experts particularly stressed the point that because the facts related to the end of occupation may vary from case to case, it does not mean that the legal criteria for assessing those facts would also vary accordingly. Some experts then asserted that the criteria for determining the end of an occupation should reflect the rationale of the occupation concept, which is the ability of foreign forces to replace the local governmental authority by invading its territory and establishing a presence there without securing consent for it. In this regard, these experts were also of the opinion that foreign military presence, the ability to exert authority over the territory in question and absence of consent were the only criteria that reflected the rationale stemming from Article 42 of the Hague Regulations, which remains the central IHL provision related to the concept of occupation.

Consequently, some of the experts emphasized the point that an occupation could not be said to exist when the foreign forces had withdrawn completely from the territory concerned. According to them, one could not then support the continued application of occupation law and claim that the foreign forces still bore responsibilities under this body of law, because those troops would not be in a position to fulfil the related obligations. This would totally contradict the principle of effectiveness that pervades IHL, occupation law in particular. The absence of foreign troops should not serve only as an indicator for assessing the end of occupation but should be maintained as a 
prerequisite for determining the end of occupation as well. ${ }^{24} \mathrm{~A}$ participant pointed out that one should not build arguments for artificially maintaining the framework of occupation law, especially when this might require the foreign forces to re-invade an area they had left. In other words, it was underscored that occupation law could never oblige foreign forces to re-occupy territory from which they had completely withdrawn. ${ }^{25}$ One expert added that once foreign troops had left a territory they had been occupying, the occupation law framework vanished and new legal bases should be elaborated for the residual responsibilities that could still be borne by the former occupant. ${ }^{26}$

As to the role of consent in assessing the end of occupation, one expert expressed the view that a local government under the authority of an occupying power could not by definition give free and genuine consent. He said that the possibility of free consent can exist only when both parties are independent. In this regard, he claimed that an agreement concluded during an occupation for the purposes of obtaining consent to the foreign forces' presence - leading ultimately to the end of the occupation - would in any case reflect the subordination of the local government's will to that of the occupying power and implied biased, if not coerced consent. The expert also held that Article 47 of the Fourth Geneva Convention would "freeze" the situation and entailed the presumption of continued application of occupation law until the occupying power had transferred its provisional authority to the local government. ${ }^{27}$ For this expert, the end of occupation would get under way only with the complete withdrawal of the foreign forces, accompanied by full empowerment of the local government.

This position was challenged on the basis that genuine consent could be given during an occupation and could result in its termination. Some experts emphasized that a local government with a good deal of authority and credibility, and accepted as being a representative body, could perfectly easily emerge during an occupation. Consequently, the theory postulating that no consent could be expressed during occupation was dismissed: this theory would ultimately result in absurd situations, e.g. the existence of a never-ending occupation. Citing the case of Iraq, an expert pointed out that even fakes and fictions could acquire momentum and become reality. With the passing of time, it would become more and more difficult to hold the view that the Iraqi government was a counterfeit with no authority at all. This position was not disputed by the participants.

Attention was drawn, from another perspective, to the difficulty of assessing the role of consent in determining the end of an occupation. Some experts contended that for this purpose, consent could not be evaluated in the same way as for the beginning of occupation. Article 47 of the Fourth Geneva Convention was cited in this regard: it expressly excluded the consent of the authorities of the occupied territory as a basis for depriving protected persons of their rights under occupation law. Attention was also drawn to the difficulty of distinguishing consent within the framework of Article 47 of the Fourth Geneva Convention from the notion of consent for the purposes of determining the end of occupation; this was owing to the fact that consent of both kinds could have similar consequences.

Nonetheless, the use of Article 47 of the Fourth Geneva Convention for determining the end of occupation was challenged. It was argued that this provision had nothing to do with the end of

24 However, one expert was persistent that military presence was only an indicator. He explained that modern occupations showed that effective control could be enforced from outside, and concluded by declaring that the applicability of occupation law could not rely only on the necessity of having foreign boots on the ground. For this expert, the key element in determining whether or not an occupation had been terminated remained the foreign forces' ability to interdict the independent exercise of local governmental authority. He said that in such instances, the foreign forces' scope of obligations under occupation law would be determined by applying Article $6 \$ 3$ of the Fourth Geneva Convention.

25 The expert cited the situation in the Gaza Strip as an example. He said that continuing to refer to it as the occupying power in the Gaza Strip would compel Israel, in order to fulfil its duties under the law of occupation, to re-assume a military presence in the area. According to the expert, an artificial legal construction that would lead to maintaining a state of occupation where effective control had been concretely relinquished could only weaken the case for occupation law. In fact, the so-called occupying power would be put in the position of not being able to fulfil its duties under occupation law unless it re-deployed its troops and re-established its military authority over the foreign territory. Ultimately, such a scenario might have adverse consequences for civilians in the territory in question, since it would require the undertaking of a significant military operation that might be potentially damaging to them.

26 On the concept of residual responsibilities, see infra.

27 Article 47 of the Fourth Geneva Convention states that "Protected persons who are in occupied territory shall not be deprived, in any case or in any manner whatsoever, of the benefits of the present Convention by any change introduced, as the result of the occupation of a territory, into the institutions or government of the said territory, nor by any agreement concluded between the authorities of the occupied territories and the Occupying Power, nor by any annexation by the latter of the whole or part of the occupied territory." 
occupation and dealt with a completely different matter: denial of the rights of protected persons during occupation. In this regard, the importance of distinguishing between consent given in the framework of Article 47 of the Fourth Geneva Convention and consent expressing the acceptance of foreign forces on one's territory was underlined. It was also affirmed that the end of occupation could never result in the restriction of protected persons' rights, but would in fact lead to an enhancement of those rights since such consent would restore the local population to a situation in which the latter was answerable only to its own government.

This position was contested by some experts, who maintained that it would still be very difficult to distinguish between the two forms of consent, since an agreement aimed at ending the occupation would necessarily result in the denial of all the rights of the local population under occupation law, which would cease to be applicable. Consequently, consent under Article 47 of the Fourth Geneva Convention and consent for the purposes of ending occupation would lead to the very same situation: the inapplicability of occupation law and, by implication, the suspension of the protections granted by IHL to the population of the occupied area.

The participants granted this point, but emphasized that it was the situation on the ground that would always be the decisive factor: if that does not change, and foreign forces continue to exert effective control over the area concerned, the agreement - irrespective of its legal basis - would be meaningless and ultimately, the occupation would continue.

One expert concluded by declaring that assessing the end of occupation would always be difficult because it would always have to deal with a variety of complex issues. Ultimately, one can say that occupation has ended only when the prevailing facts reflect transfer of governmental authority in one form or another. Otherwise, there would be a strong presumption that consent had been engineered and was therefore null and void for the purposes of determining the end of occupation.

At this stage, a majority of the experts were inclined to admit that the criteria for determining the beginning and the end of occupation were the same. However, one expert rejected the emerging consensus: he disputed the view that Article 42 of the Hague Regulations was the only provision relevant for assessing the end of occupation. In fact, he said, the advent of the Fourth Geneva Convention, and its Article $6 \$ 3$ in particular, ${ }^{28}$ sanctioned a new definition for the end of occupation, one that changed the central criterion for evaluating the end of an occupation, from effective control to the exercise of governmental powers or "functions of government." To this end, this expert said, two different tests could be proposed for the applicability of the Hague Regulations and the Fourth Geneva Convention, the latter being based not on territoriality, but on the relationships between the occupying power and the occupied population. He argued that Section III of the Fourth Geneva Convention, on occupied territories, could be applicable even if the criteria inferred from Article 42 of the Hague Regulations were not met. The expert therefore proposed a test according to which a state of occupation would endure as long as the foreign forces were engaged in acts that had a compelling effect on the local government and the civilian population of the area concerned. Therefore, occupation law would continue to regulate the actions of the foreign forces not only when they were still exercising governmental functions in the area concerned, but also when they prevented the local government from carrying out tasks and responsibilities related to the administration of the territory.

However, this argument was contested. One expert asserted that a test based solely on the functions of government exerted by the foreign forces should be rejected insofar as it was premised on a misinterpretation of Article $6 \$ 3$ of the Fourth Geneva Convention. In fact, Article 42 of the Hague Regulations and Article $6 \$ 3$ of the Fourth Geneva Convention were two distinct provisions pertaining to different specific materia. In any case, Article $6 \$ 3$ of the Fourth Geneva Convention was not intended to provide a criterion for assessing the beginning and end of occupation, but only to regulate the end or the extent of the Convention's applicability on the basis that occupation would still continue. In this respect, it was asserted that one should not substitute a test based solely on the exercise of governmental functions for the test derived from Article 42 of the Hague Regulations,

Article $6 \$ 3$ of the Fourth Geneva Convention states: "In the case of occupied territory, the application of the present Convention shall cease one year after the general close of military operations; however, the Occupying Power shall be bound, for the duration of the occupation, to the extent that such Power exercises the functions of government in such territory, by the provisions of the following Articles of the present Convention: 1 to 12, 27, 29 to 34, 47, 49, 51, 52, 53, 59, 61 to 77, 143 ." 
which remained the only relevant one as the 2005 decision of the ICJ on the case of the Democratic Republic of the Congo v. Uganda demonstrated.

Addressing the issue of exercise of authority in the end-of-occupation assessment, one expert highlighted the importance of making certain that some forms of transfer of authority from the former occupant to the local government were effectively materialized. The local government should be exercising authority that had previously been exerted by the occupant: only then can one draw the inference that a process of ending the occupation was in motion. The expert went a step further, stating that the end of occupation should be recognized only after the governmental responsibilities previously exerted by foreign forces had been fully handed over to the local authorities. Any transfer of competences short of this would continue the state of occupation and the application of occupation law for the responsibilities retained by the foreign forces. This position was rejected by one participant, who specified that empowerment of the local government was not a precondition for ending an occupation, since IHL was silent on the issue. In this regard, one can easily imagine a situation in which foreign troops completely withdraw from the territory they had occupied and leave behind a vacuum of authority. In such a case, there would be no legal basis under IHL for continuing to apply occupation law and to assign the related obligations to the former occupying power. The expert then asserted that the criterion related to the exercise of authority in the end-of-occupation test - besides the lack of foreign military presence on the ground - should not be empowerment of the local government; it should be solely the relinquishing of competences formerly exerted over the concerned territory.

Some experts challenged these positions, saying that full transfer of authority or relinquishing of competences would raise the bar too high for determining the end of the applicability of occupation law. According to them, the situation was fraught with potentially far greater complexities: for instance, when foreign troops withdraw but still retain some authority, when foreign forces' authority is seriously affected by armed resistance and when the situation on the ground leads to competition in exercising authority - between the occupant and local government. These experts doubted that, in such cases, occupation law would still be applicable and that the situation would still be considered an occupation for the purposes of IHL. They also indicated that a new legal basis - including IHL without occupation law - was required for dealing with such ambiguous situations.

Given the various forms that the end of occupation can take - particularly when the progressive phasing out of foreign forces is accompanied by the retention of competences - and the absence of consensus on the criteria for ascertaining the end of occupation, some experts expressed a need for flexibility in applying occupation law. In this regard, the experts brought up two linked issues: the "functional" application of occupation law and the existence of residual responsibilities after foreign forces have withdrawn.

\section{THE FUNCTIONAL APPLICATION OF OCCUPATION LAW AND THE NOTION OF RESIDUAL RESPONSIBILITIES}

One expert described the functional approach - also referred to as the "variable-geometry theory" - as permitting the continued application of occupation law in certain territories as long as the foreign forces still retained competences vis-à-vis the local population and government, within the territorial and functional limits of these competences. In other words, the applicability of occupation law would be limited to the functions still exercised by the foreign forces and would not apply to those handed over to the local government. The expert asserted that the legal basis for this "variable-geometry theory" could be found in Article $6 \$ 3$ of the Fourth Geneva Convention, which implied, one year after the general close of military operations, a division of responsibilities between the occupying power and the local government. Some experts were then tempted to apply the theory to the end-of-occupation process. This would enable the continued application of occupation law - and consequently the state of occupation - as long as the foreign forces retained some authority or competences over a specific area.

A few experts challenged this position, noting that the "variable-geometry theory" had been developed upon the premise that effective control would still be enforced and consequently assumed that the criteria set out in Article 42 of the Hague Regulations would still be met. These experts then 
asserted that one should not confuse a theory aimed at delimiting the scope of the occupying power's obligations within an already well-established occupation with the functional approach used as a test to determine the legal framework applicable to a situation in which foreign forces still exerted some form of authority over a territory they had previously occupied. According to some participants, the latter test would not find any legal basis under IHL, but the "variable-geometry theory" would derive expressly from Article $6 \$ 3$ of the Fourth Geneva Convention.

Other experts expressed some concerns vis-à-vis the functional approach/"variable-geometry theory." In fact, they interpreted occupation law as a package deal and, consequently, rejected the idea that the occupying forces could "pick and choose" from the applicable provisions of IHL. These experts saw potential for abuse in the application of occupation law based on the functional approach as well as risks for the protection given by this body of law, which was premised on a fragile balance between military exigencies and the interests of the local population. These experts favoured a binary approach to the application of occupation law: either the foreign forces exercise effective control and respect all the related responsibilities or they are not occupying forces and therefore not bound by occupation law.

One expert, nonetheless, tried to reconcile the two approaches. While stating that the functional approach/"variable-geometry theory" would be applicable only in a situation of well-established occupation, he stressed the point that the occupying forces would in any case be bearing the overall or ultimate responsibility for the occupied territory as required by occupation law. This would mean that the occupying power would continue to be responsible for the competences it had previously transferred to the local government when the latter was unable to implement them. This interpretation would ultimately be in line with occupation law, which allows room for a vertical sharing of authority in the occupied territory; it would also respect one of the rationale underlying the corpus juris, i.e. the division of responsibilities between governments, with a view to preventing a vacuum of authority.

These discussions highlighted the necessity of identifying with more precision the legal framework of reference applicable when foreign forces were exercising competences while withdrawing from the status of occupant for the purposes of IHL. As the prevailing facts might show, the foreign forces' show of authority does not necessarily end with their withdrawal from a territory previously occupied and the local population might still need legal protection. Although a consensus emerged as to the existence of residual responsibilities incumbent upon a former occupying power, the discussions revealed a fault line among the experts on the legal basis of such responsibilities.

Indeed, some participants argued that the remaining aspects of occupation (i.e. the competences retained by the former occupying power) would continue to be governed by occupation law even if effective control had been concretely relinquished. One expert drew a parallel between the legal framework applicable to the invasion phase and the one pertinent to the occupation's phasing out. The local population needed legal protection in both situations and occupation law remained the most suitable body of law for the purpose. Consequently, one could easily find the legal basis for dealing with the issue of residual responsibilities under occupation law in the so-called "Pictet theory" for the invasion phase. In this approach, the continued application of certain parts of occupation law would not be based on the territorial dimension of the concept of occupation, but on the nature of the responsibilities retained, in order to identify the relevant occupation law obligations irrespective of the effective control enforced by the foreign forces. In other words, it was argued that, in such cases, occupation law would still be applicable within the functional limits of the control or competences retained by the withdrawing armed forces. It was also considered that that flexibility, the need for which had been expressed in connection with assessing the beginning of occupation, would also be very relevant for assessing the end of occupation and would justify the continued application of some provisions of occupation law as long as the foreign forces continued to exercise responsibilities over the area in question.

Two experts nonetheless contested the view that occupation law could provide an adequate legal basis for those residual responsibilities. They drew attention to the fact that occupation law norms were calibrated to take effect only when a certain amount of control had been established over a given foreign territory; this point would be reached only when the criteria identified in the previous working sessions had been met. Therefore, these experts argued, it would not be wise to detach 
the application of occupation law from the concept of effective control for the purposes of IHL. The residual responsibilities exercised by the former occupying power should be governed by other bodies of law, such as human rights law or even residual IHL, since occupation law would no longer be applicable. In this regard, one expert warned against the danger of cramming everything into occupation law and underlined the necessity of not stretching this corpus juris beyond its breaking point, as that would ultimately challenge the principle of effectivity on which occupation law was premised. This would particularly be the case if one were to attempt to impose obligations under occupation law on foreign forces that were not in a position to respect them, insofar as this body of law's positive obligations, to be implemented effectively, usually required the presence of 'boots on the ground.'

\section{PART THREE: MULTINATIONAL OCCUPATION}

\section{A. THE APPLICABILITY OF OCCUPATION LAW TO UN OPERATIONS}

The experts got the discussions under way by addressing the applicability of occupation law to operations under UN command and control. Some of the experts drew attention to the existence of a long-standing position whose relevance they then challenged: according to this position, the UN could never be an occupying power. Although they acknowledged the political sensitivity of the issue, most of the participants agreed that in certain circumstances, occupation law could perfectly well be applicable to operations under UN command and control. Nevertheless, the experts were almost unanimously of the view that political considerations should not affect the determination of the applicable legal framework, even in situations involving multinational forces.

Some experts also pointed out that certain UN missions entailed the exercise of functions and powers over a territory that could be compared to those assigned to an occupant under occupation law: they cited the UN's operations in Cyprus, Cambodia, Eastern Slavonia, East Timor, Kosovo and the Congo (in the 1960s). The majority of experts stressed the relevance of occupation law in such situations, insofar as it would be the only body of law addressing the tension between the suspended sovereignty and the new administering authority. The experts added that occupation law would also be very useful since it was the only corpus juris detailing the rights and duties to be respected by a foreign provisional authority in a given territory. The experts again stressed the relevance of occupation law in such cases, irrespective of whether it applied de facto or de jure. In this connection, one expert declared that occupation law could not apply de jure when the UN mandate for administering a territory derived from a Security Council resolution. For this expert, the rights and obligations binding upon a UN mission would be determined primarily by the Security Council mandate. In such circumstances, the expert recognized only the de facto applicability of occupation law based on its usefulness, notably in connection with such matters as requisition, administration of public properties and handling of private properties. Kosovo was mentioned as an example of the de facto application of occupation law by the UN administration.

The experts then tackled the criteria for determining whether occupation law would be applicable to UN operations. One expert stated that, even if the UN exerted effective control over a territory, only the Security Council resolution and the related mandate assigned to the UN could establish the status of the UN forces and consequently the applicable legal framework. This position was supported by another participant, who pointed out that UN administration of foreign territory had nothing to do with belligerent occupation and the related IHL framework since it would be governed only by a special regime set up in an ad hoc manner by the Security Council.

Most of the experts disputed these views. In fact, they said, in accordance with the strict separation between jus ad bellum and jus in bello, IHL applicability, including occupation law applicability, could be based only on the prevailing facts and should not rely exclusively on a Security Council resolution and mandate even if the latter could to a certain extent influence the former. These experts asserted that the applicability of occupation law to the UN - including UN administration of foreign territory - should be evaluated only on the basis of the "classic" criteria for determining a state of occupation, which had been identified during the previous working sessions. They were of the opinion that in this regard, effective control was the key concept. Therefore, the presence of UN forces, their ability to exercise authority over the territory in question and the absence of 
consent from the local government were the preconditions to be fulfilled in order to classify the UN operation as an occupation for the purposes of IHL. Attention was also drawn to the fact that a Security Council mandate and belligerent occupation were not mutually exclusive, as demonstrated by Resolution 1483 on Iraq.

However, these experts also held that even if the Security Council could not unilaterally set aside reality and deny that effective control was being exerted when the prevailing facts said otherwise, it could - by application of Article 103 of the UN Charter - discard the application of provisions of occupation law that would not be relevant for implementing the UN mandate, to the extent they did not qualify as jus cogens norms. The experts asserted in this regard that the Security Council resolution should be explicit in excluding some of the norms of occupation law. In other words, when the Security Council gives a mandate, with a view to controlling and administering a territory without the consent of the local government, the situation that results would amount to an occupation and create a presumption of the applicability of occupation law, except when the Security Council expressly decides in the relevant resolution, in accordance with Article 103 of the UN Charter, that some specific provisions of this body of law would not apply.

In conclusion, one expert proposed that the applicability of occupation law to UN operations be based on two alternative grounds: fulfilment of the legal criteria identified in the previous working session and a functional approach, which would entail the de facto application of occupation law when UN forces perform tasks similar to those normally assigned to an occupying power under IHL. No one objected to this proposal.

\section{B. OCCUPATION CONDUCTED BY A COALITION OF STATES}

In light of the recent occupation of Iraq by a coalition of States, the experts addressed a question with important practical consequences: in a situation of multinational occupation, who qualifies as an occupying power? Owing to time constraints, the discussion was not as detailed as the complexity of the subject merited. Even so, the experts were able to make some useful recommendations during the working session.

One expert put forward what he referred to as a functional approach to determining which member States involved in a multinational operation exerting effective control over a territory could be defined as occupying powers for the purposes of IHL. According to this approach, among a coalition of States, the occupying powers would be those whose national contingents had been assigned responsibility for or who exerted effective control over parts of the territory concerned. Within this territory, those troops should be performing functions for which respect for occupation law could be relevant. In other words, it is the actions performed by the foreign forces and the functions they had been assigned that turned the States to which they belonged into occupying powers.

While recognizing the relevance of such a position, another expert put forward a different approach, based on the law of State responsibility. The expert asserted that in this regard, the International Law Commission's Draft Articles on the Responsibility of States for Internationally Wrongful Acts could be a useful tool for distinguishing between members of a coalition who were involved in an occupation and those who were not. According to this position, if the actions of a member State's armed forces could be attributed exclusively to the organization running the coalition per se or to other States participating in the coalition, the State in question should not be classified as an occupying power because it had relinquished effective or overall control over the troops that it had put at the coalition's disposal.

This was contested by an expert who argued that the principles used for applying secondary rules of international law were not necessarily the same as the criteria that set in motion the application of primary rules of international law (such as IHL). The expert dismissed the approach that used the principles of the law of State responsibility to determine whether a State was an occupying power for the purposes of IHL. This expert asserted that only two options should be investigated to identify the occupying powers among a coalition enforcing effective control over a territory. The first consisted of applying, to each Member State separately, the legal criteria for occupation identified during the previous working sessions. Each member of the coalition would need to have troops deployed on the ground without the local government's consent and would have to be able to exert authority 
over the parts of the occupied territory to which it had been assigned in order to be defined as an occupying power. The second option was to use a functional approach based on the tasks performed within the coalition. Those member States performing tasks that would typically be carried out by an occupying power within the framework of IHL should be labelled as such and be bound by the rules contained in the relevant instruments of occupation law. The second option seemed to find support among most of the experts.

Another participant, while supporting, in theory, the functional approach proposed above, nonetheless highlighted the practical difficulty of differentiating the legal status under IHL of the various partners within a coalition running a country, given that there was a sliding scale of activities ranging from humanitarian assistance to exercising administrative authority on behalf of the occupying powers. He drew attention to the practical problems that could arise from the curious status of participating in an occupation without being an occupying power. According to this expert, carrying out tasks at the behest of the "recognized" occupying powers would tend to confer the status of 'occupying power' on those doing so, particularly when such tasks are essential to the running of the occupation and to the performance of the related administrative tasks.

It was also pointed out that any task performed by a coalition member, even if not a core one in terms of occupier's duties under IHL, would contribute to the running of the occupation, since it would - if nothing else - free the "uncontested" occupying powers from doing secondary tasks and allow them to focus on the main ones, such as enforcing law and order. Consequently, the actions of "cooperating" member States would appear to be in support of the occupying power and would make the task of determining coalition members' legal status particularly difficult, at least from the enemy's perspective. It was also asserted by some experts that changes over time in the occupying power's rights and duties vis-à-vis the occupied territory and the now recognized role of full-fledged administrator, stemming from the prevailing interpretation of Article 43 of the Hague Regulations and Article 64 of the Fourth Geneva Convention, had made it virtually impossible to observe the distinction mentioned above, between primary and secondary tasks, since all those tasks would fall under the occupant's realm under lex lata. In this regard, it would be very difficult to make legal distinctions between coalition members based on their status under IHL. Thus, a presumption - albeit rebuttable - of occupier's status for those States participating in a coalition enforcing effective control over a foreign territory was put forward.

In conclusion, many experts underscored the complexity of the issues addressed and stated that determining an occupying power's status in a multinational occupation was an issue that deserved more clarification and elaboration. 


\title{
"EFFECTIVE CONTROL": A SITUATION \\ TRIGGERING THE APPLICATION OF THE LAW \\ OF BELLIGERENT OCCUPATION
}

\author{
BACKGROUND DOCUMENT BY PROF. MICHAEL BOTHE
}

\section{THE BACKGROUND: THE CONCEPT OF BELLIGERENT OCCUPATION}

Belligerent occupation is as necessary an ingredient of armed conflict as is fighting. Therefore, the balance of interest between an occupying power and a partly or wholly occupied State is a traditional issue of the law of armed conflict as it has developed since the legal civilization of war in the 18th century. It is in this context that the law of belligerent occupation has developed as a specific area within the law of armed conflict. It was codified in the Hague Regulations of 1899/1907. These provisions constitute customary law. The Fourth Geneva Convention of 1949 developed this regime considerably. Additional Protocol I of 1977 only added a few details.

There have always been forms of military presence where it was at least doubtful whether they constituted a situation where the law of belligerent occupation applied. Only one particular question, namely the establishment of a military occupation without resistance being met, was clarified by the Geneva Conventions. Thus, the question of a definition of belligerent occupation arose.

That question of definition logically precedes the question of the beginning and end of occupation. One cannot determine when a situation of occupation begins or ends without being clear about what it is.

The occupation that the authors of the Hague Regulations had in mind develops where there is an armed conflict: the forces of one party advance and drive the forces of the other party out of parts of their own territory. In this situation, there are specific interests at stake:

The occupying power has gained an advantage that it wants to retain. Therefore, realistically, the law allows measures to be taken for that purpose by the occupying power. But the law of occupation does not grant a legal "right" to adopt such measures; the power of the occupant is a de facto power limited by law. The power exercised by the occupant is its own original power limited by international law; it is not a power delegated or derived from the State whose territory is occupied.

On the other hand, as occupation occurs during an armed conflict, a belligerent's gain may not be final. It is in the interest of the party the territory of which is occupied that no measures are taken by an occupant that make its gain final or irreversible. There are a number of rules that are inspired by the principle that the situation of occupation is provisional and temporary (prohibition of population transfers, prohibition against requiring allegiance to the occupant, limitation on the use of the resources of the occupied territory).

Third, there are the interests of the population of the occupied territory. It must, first, be protected against traditional abuses of invaders (physical maltreatment, enslavement, excessive contributions). But there is more: as the occupying power has displaced, at least to a certain extent, the pre-existing governmental apparatus, it, so to say, inherits the responsibilities of the displaced government to see to the welfare of the population, at least to the extent possible under the circumstances. In the interest of the population, any vacuum between the disappearance of the former State administration and the taking over by the occupant must be avoided, to the extent possible. 
It is on the basis of these characteristics of the situation of occupation that one must approach the question of a definition and, as a consequence, that of the beginning and end of occupation.

\section{BASIC ELEMENTS OF A DEFINITION}

Belligerent occupation is a situation where typically the tension of interests just described exists.

This tension or conflict of interests does not arise where a State admits a foreign military presence and, by an agreement, delegates certain powers to it. The agreement must of course be valid, i.e. not brought about by coercion. But even the existence of a valid agreement does not automatically exclude a situation of occupation. There may still be situations where the same conflict of interests exists. This conflict of interest does not exist where the situation is final, for instance due to an unconditional surrender.

The conflict of interests does exist where the territorial State is no longer in a position to fulfil its responsibilities vis-à-vis the population, but the foreign State is in a position to do so. It is in this context that the issue of effective control arises.

\section{THE THRESHOLD QUESTION: "EFFECTIVE CONTROL"}

The term "effective control" ${ }^{2}$ is a notion developed in the current legal discourse concerning occupation to describe one important element of determining the beginning of occupation. It is not used in a treaty.

The only treaty definition is that of Articles 42 and 43 of the Hague Regulations. The Fourth Geneva Convention does not contain a definition of its own. It must be assumed that it refers to the Hague Regulations that constitute customary law. The latter use the term "authority":

"Article 42.

Territory is considered occupied when it is actually placed under the authority of the hostile army.

The occupation applies only to the territory where such authority is established, and in a position to assert itself.

Article 43.

The authority of the legitimate power having actually passed into the hands of the occupant, the latter shall ..."

This is the official translation by the U.S. Department of State of the French text, which is the only authentic one. In order to ascertain what "actually" actually means, it is useful to have a look at the original text: ${ }^{3}$

Article 42.

Un territoire est considéré comme occupé lorsqu'il se trouve placé de fait sous l'autorité de l'armée ennemie.

(...)

Article 43.

L’autorité de pouvoir légal ayant passé de fait entre les mains de l’occupant ... 
The French text more clearly conveys the idea, already explained, that the power of the occupant is a de facto capability, not a legal authority. It is facts that matter. This idea is well rendered by the term "effective control."

Article 43 of the Hague Regulations only alludes to the fact (without making it explicit) that this definition is composed of two elements, namely the de facto disappearance of the old power and the de facto establishment of the new one. This had been expressed clearly in the Oxford Manual adopted by the Institut de droit international in 1880 :

"Art. 41. Territory is regarded as occupied when, as the consequence of invasion by hostile forces, the State to which it belongs has ceased, in fact, to exercise its ordinary authority therein, and the invading State is alone in a position to maintain order there. The limits within which this state of affairs exists determine the extent and duration of the occupation."

The same concept is expressed in the new UK Manual of the Law of Armed Conflict, according to which two conditions must be satisfied: ${ }^{4}$

"[F]irst, that the former government has been rendered incapable of publicly exercising its authority in that area; and secondly, that the occupying power is in a position to substitute its own authority for that of the former government."

It is submitted that both conditions constitute customary law as it is their combination that indeed corresponds to the tension of interests that characterizes a situation of occupation. This is so particularly in the light of the interests of the population: one government responsible for its welfare is no longer in a position to fulfil that responsibility; another one that can do so has to step in.

Both conditions require some comment.

The typical situation that is the point of departure for the Hague Regulations and the Oxford Manual is the invasion. The situation envisaged is that the armed forces of the invaded State had to withdraw, and that therefore the government of that State no longer has any grip on the local authority of the area that has been invaded. It is the absence of governmental authority that fulfils the condition, not the absence of any public authority. The local police forces in charge of maintaining order may still be there, albeit not necessarily. But even if they are still functioning, the authority of the government can no longer be exercised - which is the essential point. Any claim of long distance impact, for instance the claim of legislative powers by a government in exile, does not change the fact that the old government is de facto unable to exercise its authority over the area.

For similar reasons, a situation of occupation may also occur where the Security Council authorizes the foreign military presence. The authorization is a question of the ius ad bellum; it has nothing to do with the question whether a pre-existing authority disappeared or not.

Displacing the existing government by an invasion is not the only possible scenario. In the case of a failed State, the governmental authority may have disappeared well before a foreign presence began.

A situation of occupation may also arise where foreign forces are present in a territory with the consent of the government and this consent is withdrawn. Again, this is, first of all, a question of the ius ad bellum. The most likely scenario in this situation is that the existing government continues to exercise its functions. Only if this is not the case can a situation of occupation develop. In the case of $D R C$ v. Uganda, the ICJ critically reviewed the question whether the Ugandan troops had effectively displaced the Congolese authorities and found that this had happened only in a particular area. ${ }^{5}$

The second condition does not present any problem where the foreign State indeed effectively exercises all the powers that an occupant is allowed or supposed to exercise. If it does not, this may be because it cannot do so or because it does not want to do so. The impossibility of exercising those powers may be objective, i.e. a security situation where the would-be occupant is objectively

Section 11.3

$\$ \$ 172$ et seq. of the Judgment of 19 December 2005. 
prevented from exercising those powers, or subjective, i.e. if the occupant lacks the resources to do so.

The objective impossibility is a clear case of the ultra posse nemo obligatur rule. The same conclusion can be derived from the text of Article 42 of the Hague Regulations: in this case, the authority of the would-be occupant cannot "establish itself." There is no occupation with the ensuing obligations of the occupant. Lack of resources, however, is a difficult question under the law of armed conflict. It also arises as to the adequate treatment of persons who are in the hands of the enemy. May a party to a conflict lawfully deny food to prisoners because it is not able to procure the necessary provisions? It should be quite clear that a party facing such a situation must at least make a reasonable effort to procure the necessary food. If it fails to do so, it is acting unlawfully.

These considerations also determine the situation where a State is just unwilling to effectively establish its authority over an area of foreign country. In this respect, it is useful to recall the text of Article 43 of the Hague Regulations:

"The authority of the legitimate power having actually passed into the hands of the occupant, the latter shall take all the measures in his power to restore, and ensure, as far as possible, public order and safety, while respecting, unless absolutely prevented, the laws in force in the country."

This responsibility of the occupant to re-establish order and safety is the first point in the enumeration of duties of an occupant contained in the Hague Regulations. It is one of the basic elements in the balancing of interests that characterizes the law of occupation. This basic goal of the law of occupation cannot be frustrated by an occupant simply refusing to establish the control it is in a position to establish. In other words: the expression "having actually passed into the hands of the occupant" means a situation where the foreign power can, and therefore must, exercise the power to maintain order in the country. This idea is well rendered by the formulation of the Oxford Manual and the new UK Manual, which do not use the words "exercises effective control" or similar ones, but the expression "is in a position."

This interpretation of what constitutes the beginning of an occupation does not exclude the possibility of a vacuum between the disappearance of the old "legitimate" power and the establishment of the new de facto power. It tries, however, to reduce that vacuum. It is obvious that while and where fighting is going on, the invading power has no responsibility for maintaining order in the area. But once the invader has established its presence and the armed forces of the country have withdrawn or disappeared, the invader obtains this responsibility and must act accordingly.

That threshold question also has a territorial aspect: a situation of occupation exists only in those areas where the new de facto authority is indeed established, a question critically examined by the ICJ in the case of DRC $v$. Uganda. ${ }^{6}$ A certain minimum territorial scope of occupation is necessary in order to speak of an effective occupation. However, it is difficult to determine what that is.

\section{THE SECOND THRESHOLD QUESTION: EFFECTIVE CONTROL AND THE ESTABLISHMENT OF JURISDICTION IN THE SENSE OF HUMAN RIGHTS LAW}

What does the foregoing analysis of situations of foreign military presence mean for the parallel application of international humanitarian law and the law of human rights? The European Court of Human Rights in the Loizidou case and the ICJ in the Advisory Opinion concerning the Construction of a Wall in the Occupied Palestinian Territory have clarified beyond any reasonable doubt that this parallel application is possible. It is the law where both legal regimes apply according to the provisions that determine their respective scope of application. That question has just been analysed as to a particular sub-area of the law of armed conflict, namely the law of occupation. It

$6 \quad$ Loc. cit., note 33. 
has now to be asked: What is the meaning of the corresponding rules of the law of human rights? The key notion that triggers the applicability of human rights obligations is the exercise of "jurisdiction." A State has to respect the human rights of those persons who are subject to its jurisdiction. The ordinary meaning of the term should be clear: fighting is not an exercise of jurisdiction (which does not exclude the possibility of fighting taking place in an area where jurisdiction exists for other reasons, the typical situation in non-international armed conflict). This has been made clear by the European Court of Human Rights in the Banković case. There is, however, a threshold when fighting has ceased and control is actually established. This is the moment in time when "jurisdiction" in the sense of the law of human rights begins. The most telling case in this respect is the Issa case of the European Court of Human Rights concerning military operations by Turkey in northern Iraq. In essence, the Court asks whether, when the alleged violations occurred, a situation of fighting was over and actual control established by Turkey. The Court held that the latter could not be proved and that therefore no violation of the European Convention by Turkey could be established.

It has to be asked whether the considerations developed for the step from fighting to de facto authority, which characterizes an occupation, apply in a similar way to the establishment of jurisdiction in the sense of human right law. It is submitted that it does, even a fortiori. It is inherent in the object and purpose of international human rights norms, which is to promote the realization of human rights for everybody, that a State must take steps for this promotion once it is in a position to do so. Unwillingness to exercise jurisdiction cannot be a means to evade this responsibility. 


\section{THE TERMINATION OF MILITARY OCCUPATIONS}

\section{BACKGROUND DOCUMENT BY PROF. ADAM ROBERTS}

The question of when an occupation ends matters. It is not a theoretical exercise, but affects such key issues as (1) the nature and extent of legal obligations on armed forces and governments involved in a conflict; and (2) how the legitimacy or otherwise authority of the government of the territory concerned is viewed both by inhabitants and by others.

Most legal writings indicate that a military occupation of territory ends when the foreign troops leave. As one classic work on international law put it, "Occupation comes to an end when an occupant withdraws from a territory, or is driven out of it."' In many cases, such a statement expresses a simple truth, and thus poses no problems of interpretation.

However, the practice of States indicates that withdrawal of occupying forces from the territory is not the sole criterion for the ending of an occupation. The resumption, or emergence, of fighting within the occupied territory has sometimes been considered to lead to an end (whether temporary or permanent, general or local) of the status of occupation. Furthermore, a formal announced ending of an occupation can take many different forms. For example, in some cases the occupying power has not necessarily withdrawn all its forces at the end of all occupations, but has instead significantly changed their practical functions and legal status; and/or a political act of self-determination within the occupied territory has been considered the crucial determinant of whether an occupation can be said to have ended.

The question of whether an occupation has ended is often politically contentious, and the subject of sharply different views. For example, disputes over the status of Iraq since June 2004 and Gaza since September 2005 illustrate some of the difficulties. Even if, as in Gaza, the occupying forces have withdrawn, the former occupant, for example on account of geographical closeness and involvement in the economy of the territory, may have a continuing role that some see as potentially analogous to occupation. This and other instances raise the question of whether there can be a satisfactory way of determining whether occupation has ended, and whether the application of humanitarian rules has to depend on such determination.

This paper proceeds by looking first at treaty provisions regarding the end of occupations; secondly by laying out three basic types of ending; thirdly by looking at issues raised in two contemporary cases, Iraq and Gaza; and finally by a brief discussion of the implications of this analysis.

\section{TREATIES}

\section{THE 1899 AND 1907 HAGUE REGULATIONS}

Treaties in the field of the laws of war (i.e. international humanitarian law) do not address the ending of occupation directly, but they do imply a clear view of the matter by the way in which they frame the concept of occupation. The 1907 Hague Regulations, like those of 1899, appear to be based on an assumption that a military occupation occurs in the context of a war, and consists of direct control of one hostile State's territory by a rival hostile State's armed forces. Some of this is evident from the very title of the part of the Regulations that deals with the question of occupation: "Military Authority Over the Territory of the Hostile State." The first article in this part of the Regulations - Article 42 - establishes an apparently simple factual basis for determining what an occupation is:

"Territory is considered occupied when it is actually placed under the authority of the hostile army.

\footnotetext{
L. Oppenheim, International. Law: A Treatise, Vol. 2, Disputes, War and Neutrality, 7th edn., ed. Lauterpacht, Longmans
} Green, London, 1952, 436. 
The occupation extends only to the territory where such authority has been established and can be exercised."

The implicit assumption here, that an occupant exercises authority directly, through its armed forces, rather than indirectly, through local agents, is also evident in Article 43, which begins: 'The authority of the legitimate power having in fact passed into the hands of the occupant ...' Direct control by the occupant also seems to be taken for granted in Articles 48, 49, 51-3 and 55. An open and identifiable command structure is thus a central feature of the Hague definition of military occupation.

\section{THE 1949 GENEVA CONVENTIONS}

After the Second World War, the need was felt for a more adequate definition of the cases to which the laws of war, including the law on occupations, applied. As far as occupations were concerned, there had been many, especially in the period 1938-45, that differed in important respects from the implicit definitions of the Hague Regulations. Czechoslovakia and Denmark were leading examples. These occupations did not begin with war between the parties as envisaged at The Hague. Czechoslovakia had been invaded and occupied without military resistance and before the outbreak of the war, not as a consequence of war; and Denmark, which was invaded and occupied during the war, only put up minimum military resistance to the invasion. The forms of administration also differed from what was envisaged at The Hague. In both countries there were periods when the Germans exercised control partly through indigenous governments. Moreover, in Czechoslovakia there were additional complications, not least its purported abolition as a State in March 1939. A clarification was needed that the laws of war applied to these and other types of occupation.

The main result was the adoption of Article 2 common to the four 1949 Geneva Conventions (common Article 2). This states, in full:

"In addition to the provisions which shall be implemented in peacetime, the present Convention shall apply to all cases of declared war or of any other armed conflict which may arise between two or more of the High Contracting Parties, even if the state of war is not recognized by one of them.

The Convention shall also apply to all cases of partial or total occupation of the territory of a High Contracting Party, even if the said occupation meets with no armed resistance.

Although one of the Powers in conflict may not be a party to the present Convention, the Powers who are parties thereto shall remain bound by it in their mutual relations. They shall furthermore be bound by the Convention in relation to the said Power, if the latter accepts and applies the provisions thereof."

In the Fourth Geneva Convention of 1949 (the Civilians Convention), many other provisions besides common Article 2 indicate that occupation is conceived of more broadly than in the Hague Regulations. The most notable such provisions are in Article 6, which refers to occupations that continue "one year after the general close of military operations." Article 6 did allow for the cessation of certain rules after that point, but the occupant (if still exercising governmental functions) would have remained bound by many conservationist rules. This "one year after" rule is widely seen as of little or no relevance to actual occupations, and, as noted below, it has been effectively rescinded by a provision of Additional Protocol I of 1977, as between States party to the latter.

In addition, Article 47 of the Fourth Geneva Convention of 1949 is relevant to the question of how an occupation ends. It takes account inter alia of two possibilities, the first being an occupation in which the authorities of the occupied territory remain in post, and the second being an attempted annexation by the occupant of the whole or part of the occupied territory. The article specifies that in neither case can such changes deprive protected persons of the benefits of the Convention. 


\section{PROTOCOL I OF 8 JUNE 1977 ADDITIONAL TO THE FOUR GENEVA CONVENTIONS (ADDITIONAL PROTOCOL I)}

Since 1949, the various new international conventions with a specific bearing on occupations have all echoed the terms of common Article $2 .{ }^{4}$ The most significant post-1949 development, so far as the scope of application of the law on occupations is concerned, is in Additional Protocol I, paragraphs 3 and 4 :

"This Protocol, which supplements the Geneva Conventions of 12 August 1949 for the protection of war victims, shall apply in the situations referred to in Article 2 common to those Conventions.

The situations referred to in the preceding paragraph include armed conflicts in which peoples are fighting against colonial domination and alien occupation and against racist régimes in the exercise of their right of self-determination, as enshrined in the Charter of the United Nations and the Declaration on Principles of International Law concerning Friendly Relations and Co-operation among States in accordance with the Charter of the United Nations."

The aim of paragraph 4 as quoted above seems to be to try to establish that certain armed conflicts that might be viewed by some as essentially internal in character, are really international, and hence fully subject to the better-developed legal regime governing international armed conflicts. As far as its specific reference to occupation is concerned, the paragraph does not concern itself directly with the definition or scope of 'alien occupation'; and it adds little to the scope of application as spelt out in the 1949 Geneva Conventions themselves. All it really does is to close a tiny technical loophole in common Article 2, by making a little clearer what was already widely accepted - namely, that the law on occupations is applicable even in situations (like the West Bank and Gaza) where the occupied territory was not universally viewed as having been part of "the territory of a High Contracting Party." As Bothe, Partsch and Solf say, it appears that the term 'alien occupation' is "meant to cover cases in which a High Contracting Party occupies territories of a State which is not a HCP, or territories with a controversial international status, and to establish that the population of such territory is fighting against the occupant in the exercise of their right of self-determination."

Article 3 of Additional Protocol I, addressing the "Beginning and end of application," makes it clear that the law can apply for a longer period in relation to occupations than in the case of armed conflict. As 3(b) states:

"The application of the Conventions and of this Protocol shall cease, in the territory of Parties to the conflict, on the general close of military operations and, in the case of occupied territories, on the termination of the occupation, except, in either circumstance, for those persons whose final release, repatriation or re-establishment takes place thereafter ...”

\section{PRACTICE: THREE BASIC TYPES OF ENDING FOR OCCUPATIONS}

There have always been difficulties in determining the actual end of occupations. For example, there have been disagreements about what level of resistance activity or overt fighting within an occupied territory leads to a situation being classified as one of armed conflict rather than occupation - at least in the particular area where fighting is taking place. As regards the formal ending of the occupation of an entire occupied territory, there can be three basic types of ending: military withdrawal, end of occupation with continued presence of foreign forces, and acts of self-determination that effectively end the condition of occupation.

1954 Hague Cultural Property Convention, Arts 5 and 18; Additional Protocol I, Art. 1; 1981 Convention on Certain Conventional Weapons, Art. I.

5 M. Bothe, K.J. Partsch and W. Solf, New Rules for Victims of Armed Conflicts: Commentary on the Two 1977 Protocols Additional to the Geneva Conventions of 1949, Nijhoff, The Hague, 1982, 51-2, support the view that this might mean in practice "the peoples of southern Africa and Palestine." 


\section{A. MILITARY WITHDRAWAL}

One post-war example of an occupation that did end with a complete withdrawal of all the occupying forces (in this case by agreement) is Austria. The occupation by the USSR, USA, UK and France, which lasted for more than ten years, was wound up in accord with the Austrian State Treaty, signed by these four countries on 15 May 1955. Later the same day, the Austrian foreign ministry published the text of a resolution on Austria's permanent neutrality to be placed before the national legislature. The last Allied troops left Austria on 24 October 1955, and on 25 October, Austria became a completely free and sovereign country. ${ }^{6}$ This date of the formal ending of the occupation is not necessarily the same as the date of the re-emergence of the Austrian State. Clute has persuasively argued that 28 June 1946 - the date of a new agreement concluded by the four occupying powers - can be interpreted as the real date of "the re-emergence of the Austrian State and a government capable of acting on its behalf." The 1955 Austrian State Treaty "merely confirmed the existence of an independent Austrian State and contributed to its stability by creating the conditions for a termination of the occupation, but did not create or re-establish the Austrian State."”

Another example of an occupation ending with a negotiated withdrawal by the occupying forces was the Israeli occupation of Sinai, which had begun in 1967, and which was concluded with a phased evacuation between 1979 and 1982 in accord with the terms of the Egypt-Israel Peace Treaty signed in Washington in March 1979.

\section{B. CONTINUED PRESENCE OF FOREIGN FORCES}

However, there are instances where an occupation is declared or widely presumed to have ended, but the occupant's forces remain in the country. This can happen, for example, if a treaty ending an occupation is accompanied by another one permitting the presence of foreign forces. Alternatively, it may happen in a less formal way.

In Japan on 28 April 1952, a Peace Treaty ending the US military occupation of the country took effect, and simultaneously a Security Treaty came into force, providing for a continued US military presence. ${ }^{8}$

Likewise, in West Germany on 5 May 1955, a number of agreements took effect simultaneously, including one that ended the last vestiges of the three-power occupation, one that provided for the continued presence of the same three countries' forces in West Germany, and others that provided for the entry of West Germany into the North Atlantic Treaty Organization and the Western European Union. ${ }^{9}$

As for East Germany, a Soviet Government statement of 25 March 1954 ended the Soviet "supervision of the activities of the German Democratic Republic," and also specified that the Soviet Union would retain in East Germany its functions connected with guaranteeing security - which of course meant that Soviet troops remained..$^{10}$ This formal ending of occupation, with external troops remaining in place, was not universally accepted. West German official publications continued for many years thereafter to refer to East Germany as the "Soviet Occupation Zone."

The complexity of the ending of occupations, illustrating the many gradations that can be involved, is illustrated by the case of Germany, and more particularly by the city of Berlin. For decades, Berlin remained in the time-warp of the four-power occupation, although the

Keesing's Contemporary Archives, 14193-8 and 14561.

R.E. Clute, The International Legal Status of Austria 1938-1955, Nijhoff, The Hague, 1962, 345 and 132.

For texts of these two treaties, both of which had been signed on 8 September 1951, see United Nations Treaty Series, Vol. 136, pp. 46 and 216 .

9 For details of the agreements on West Germany, see B. Ruhm von Oppen, Documents on Germany under Occupation 19451954, Oxford University Press, Oxford, 1955, 600-48. Most of the occupants' powers of intervention in West German domestic affairs had already been abolished in the Convention on Relations Between the Three Western Powers and the Federal Republic, signed on 26 May 1952. Text ibid. 616-17.

10 Ibid. 597-8. In 1955, several further steps were taken, including the opening of diplomatic relations between the USSR and the GDR on 20 September. 
powers of the Allies were minimal and residual. ${ }^{11}$ The occupation of Berlin, and the division of Germany, were finally brought to a formal conclusion through the September 1990 Treaty signed by East Germany, West Germany, and the four occupying powers: but the four-power forces were permitted to remain in Berlin until the end of $1994 .^{12}$ At midnight on 2-3 October 1990, East Germany ceased to exist, becoming part of the Federal Republic of Germany. ${ }^{13}$

In the cases of both Japan and Germany, a key reason for foreign forces remaining in the country after the formal ending of occupation was the need for defence against an external threat. In Japan and West Germany, the continued presence of external forces does not appear to have undermined or threatened the resumption of sovereignty by these States or their independent decision-making capacity.

\section{ACTS OF SELF-DETERMINATION}

An essential feature of the ending of an occupation is often, though not always, an act of self-determination involving the inhabitants of the occupied territory. This act of selfdetermination may well require, as prerequisite or consequence, the withdrawal of foreign forces. In the period since the late 1960s, the international community has favoured self-determination in respect of at least five occupations - those of Namibia, the West Bank and Gaza, Cambodia, East Timor and Western Sahara. ${ }^{14}$ In all five cases the withdrawal of foreign forces has been seen as one key aspect of the ending of occupation. External armed forces remain in place only in those cases in which the occupation has not (or at least not completely) ended - i.e. the West Bank and Western Sahara.

Important as acts of self-determination are, they cannot be the sole decisive criterion for determining when an occupation ends. The case for self-determination has not been pressed where an occupied territory is widely accepted as being part of an existing State, from which it has been forcefully separated and to which it may be expected eventually to revert. A case in point is northern Cyprus: any act of self-determination there might well be seen as a threat to the sovereignty and territorial integrity of Cyprus, and as a victory for the Turkish invasion and occupation. There the key test of the ending of occupation is more likely to be an agreement on constitutional arrangements for the whole of Cyprus, and the withdrawal of Turkish armed forces and personnel from the North.

Berlin was the subject of the four-power agreement of 3 September 1971, but this mentions neither the word 'occupation' nor the word 'Berlin.' For one earlier assessment of the legal status of Berlin, see the chapter by J.W. Bishop in Roland J. Stanger (ed.), West Berlin: The Legal Context, Ohio State University Press, Columbus, Ohio, 1966. A later and more comprehensive survey is I.D. Hendry and M.C. Wood, The Legal Status of Berlin, Grotius Publications, Cambridge, 1987.

12 Treaty on the Final Settlement with Respect to Germany, signed in Moscow on 12 September 1990. International Legal Materials, Vol. 29, 1186. Art. 4 specifies that the withdrawal of Soviet forces from "the territory of the present German Democratic Republic and of Berlin (...) will be completed by the end of 1994 ...” Art. 5 provides that, for the duration of the presence of these Soviet forces, French, UK and US forces "will, upon German request, remain stationed in Berlin by agreement to this effect ..." Art. 7 says that France, USSR, UK and USA "hereby terminate their rights and responsibilities relating to Berlin and to Germany as a whole."

13 Keesing's Record of World Events, 37761. A four-power declaration signed on 1 October 1990 in New York by France, UK, USA and USSR conferred full sovereignty on the new unified Germany pending formal ratification of the 12 September treaty by the legislatures of the parties.

14 UN General Assembly resolutions can be taken as one (albeit imperfect) measure of international opinion on the question of self-determination for occupied territories. On the five cases cited, see, e.g. GA Res. 2403 (XXIII) of 16 December 1968, and 43/26 of 17 November 1988 (both on Namibia); GA Res. 2672C (XXV) of 8 December 1970 (the first of many calling for selfdetermination for the Israeli-occupied Palestinian territories); GA Res. 36/5 of 21 October 1981, and 43/19 of 3 November 1988 (both on Cambodia); GA Res. 36/50 of 24 November 1981 (on East Timor); GA Res. 38/40 of 7 December 1983, and 43/33 of 22 November 1988 (both on Western Sahara) 


\section{TWO CONTEMPORARY CASES: OCCUPATION AFTER THE END OF OCCUPATION?}

Can an occupation continue even after its end has been formally proclaimed? Since the key test of the ending of an occupation is essentially factual, clearly mere proclamations are less important than the presence and actions of the foreign military forces and of the former occupying power. Two contemporary cases illustrate the salience of the question of whether occupation can have, as it were, an after-life: Iraq and Gaza.

\section{IRAQ}

The ending of the occupation in Iraq in June 2004 is a very different case from the ending of occupations in Japan and Germany in 1952-55, for three principal reasons. First, Iraq does not inherit a long tradition of sovereign and independent statehood; second, it suffers from deep internal divisions, principally those between Shiites, Sunni and Kurds; and third, it is in the midst of an extensive and unusually brutal insurgency. In short, it is as much for internal as for external reasons that foreign forces are likely to remain in the country even after the formal ending of occupation. Thus the question of how completely the occupation has ended is bound to be more contentious in Iraq than it has been in certain other cases in which troops have remained after the formal end of occupation. The international negotiations preceding the declaration of the ending of the occupation of Iraq reveal a degree of recognition that, at the very least, problems and responsibilities akin to those of an occupying power were likely to continue.

The process by which the Iraq occupation had formally ended on 28 June 2004 illustrates a problem of transformative occupations. ${ }^{15}$ While all such occupations aim at establishing a political order based on the principle of self-government, it is genuinely difficult to determine at what point one can say that the transformation has been achieved, and the government of the occupied territory is in a position to exercise the powers of sovereignty. This question is much easier to answer when a more conventional occupation ends in a more traditional way, either as a result of re-conquest of the territory by its original ruler, or as part of the terms of a peace agreement. Where what is involved is a gradual transfer of powers to the indigenous authorities as their capacity to govern is built up, there is bound to be an arbitrary element in fixing on a single date as the symbolic ending of the occupation. In this case there was political controversy as well, since critics viewed the formal ending as concealing continued US dominance of a puppet government.

At the UN, the ending of the occupation, within a framework laid down by the US government, was provided for in Security Council Resolution 1546 of 8 June 2004. This began:

"Welcoming the beginning of a new phase in Iraq's transition to a democratically elected government, and looking forward to the end of the occupation and the assumption of full responsibility and authority by a fully sovereign and independent Interim Government of Iraq by 30 June $2004 \ldots{ }^{\prime \prime 16}$

The resolution reaffirmed "the right of the Iraqi people freely to determine their own political future and control their own natural resources." It laid down a detailed road map for Iraq's future political development, including the holding, before 31 January 2005 at latest, of democratic elections to the Transitional National Assembly. (These were in fact held on 30 January 2005.) The resolution welcomed the fact that Iraqi security forces were "responsible to appropriate Iraqi ministers," and that there was to be a "full partnership between Iraqi security forces and the multinational force." It contained extensive provisions on the roles of the multinational force and of the Iraqi government, both of which were envisaged as taking a wide range of security measures. It referred three times to the promotion of human rights in Iraq as a key goal.

15 For a fuller exposition, completed at the time of the transfer of authority in June 2004, see Adam Roberts, "The End of Occupation: Iraq 2004," International and Comparative Law Quarterly, London, Vol. 54, No. 1 (January 2005), pp. 27-48.

16 SC Res. 1546 of 8 June 2004 passed unanimously. This was a substantially revised version of earlier drafts, the first of which had been presented at the UN on 24 May 2004. See also the detailed listing of the broad range of tasks of the multinational force (including even internment), and the assurance about continued fulfilment of obligations under the law of armed conflict, contained in the letter of 5 June 2004 from the US Secretary of State to the President of the Security Council. This is annexed to the resolution. 
The new situation after 28 June 2004 was not just an occupation by another name. There were real differences, including the fact that the Interim Government had an explicitly recognized right to demand the withdrawal of the U.S.-led forces in Iraq. As the Security Council put it in the same resolution:

"The mandate for the multinational force shall be reviewed at the request of the Government of Iraq or twelve months from the date of this resolution (...) and [the Council] declares that it will terminate this mandate earlier if requested by the Government of Iraq."

Yet the prospect that there would be continuing significant similarities with an occupation found reflection in certain provisions of the resolution about the application of international rules. A preambular clause, inserted fairly late in the long negotiations over the text, recognized the continued application of international humanitarian law:

"Noting the commitment of all forces promoting the maintenance of security and stability in Iraq to act in accordance with international law, including obligations under international humanitarian law, and to cooperate with relevant international organizations ...”18

The inclusion of this clause can be interpreted as one way of conceding that, even if the occupation was theoretically over, the likelihood remained that uses of force, perhaps even exercises of administrative authority, that closely resembled a situation of occupation would occur. This scenario, of course, has been played out repeatedly in the two years since the occupation notionally ended. Indeed, many continued to use the term 'occupation' in respect of Iraq and will no doubt do so as long as coalition forces are present and exercise significant influence in the management of the country.

In addition, the first operative paragraph of Resolution 1546 confirmed the incomplete nature of the transfer of sovereignty for which the resolution provided. It stated that the Security Council:

"1. Endorses the formation of a sovereign Interim Government of Iraq, as presented on 1 June 2004, which will assume full responsibility and authority by 30 June 2004 for governing Iraq while refraining from taking any actions affecting Iraq's destiny beyond the limited interim period until an elected Transitional Government of Iraq assumes office as envisaged in paragraph four below ..."

This important limitation on "taking any actions affecting Iraq's destiny beyond the limited interim period" reportedly resulted from pressure by various Iraqi groups, fearful that the position of Kurds, Shiites or others might be undermined irrevocably by actions taken by the 'sovereign' Interim Government. This constraint placed the Interim Government, paradoxically, in a position analogous to that of an occupying power. The Coalition Provisional Authority interpreted the provision as limiting the Interim Government's power to conclude treaties. The constraint bears obvious similarities to the obligations on occupying powers to refrain from making fundamental changes in the legal system of the occupied territory, and to behave generally in a trustee-like manner. The fact that the term 'caretaker government' was often used with reference to the Interim Government confirmed this interpretation. Thus, ironically, a transformative occupation challenging the very foundations of the law of the Hague Regulations and the Fourth Geneva Convention had the effect of leading to a reassertion of the conservative principles that underlie occupation law - even at the moment when the occupation was deemed to be at an end.

\section{GAZA}

In September 2005 Israel withdrew from the Gaza Strip the armed forces that had been stationed there since 1967, and also the Israeli settlements that had been established in the territory. Subsequently there were numerous armed incidents both within Gaza, and between Gaza and Israel.

7 SC Res. 1546 of 8 June 2004, operative paragraphs 9 and 12. See also the text of letters (both dated 5 June 2004) from the Prime Minister of the Interim Government of Iraq and the US Secretary of State to the President of the Security Council. These letters are annexed to the resolution.

18 There had been no equivalent clause in the draft of SC Res. 1546 presented at the UN by the US and UK on 24 May 2004. The revised draft presented on 1 June had included the clause in a shorter version than the final one. Only the final text, which was first circulated on 7 June, contained the phrase "including obligations under international humanitarian law." 
In response, Israel took a number of measures relating to Gaza, including placing limitations on fuel and electricity supplies, and on freedom of movement of individuals.

Some non-governmental bodies, including in Israel, argued that Israel continued to have general responsibilities under the law of armed conflict, and specific responsibilities under occupation law, that could not simply be shed by Israel's act of withdrawal in 2005. This matter was raised in several cases considered by the Israeli Supreme Court in 2007-08. For example, in Jaber al-Basyuni Ahmad et al. v. The Prime Minister and the Minister of Defence, the petitioners urged that certain Israeli actions in relation to Gaza breached both general rules and obligations arising from occupation law. Their petition of October 2007 called for the application to the residents of Gaza of laws of occupation, human rights law, and Israeli constitutional law. ${ }^{19}$ The petitioners sought an injunction to stop Israeli restrictions on the supply of electricity and fuel to Gaza, and Israeli sanctions against the civilian population.

In the course of its verdict in January 2008, refusing to agree to the petition, the Supreme Court stated its view of the legal situation thus:

"The State argued before us that it is acting in accordance with the principles of international law and is fulfilling its humanitarian obligation under the laws of armed conflict. According to the State's representative, these obligations are limited and are derived from the state of armed conflict that exists between the State of Israel and the Hamas organization which controls the Gaza Strip, and from the need to prevent harm to the civilian population that finds itself living in a combat zone. In this regard, we note that since September 2005 Israel no longer has effective control over what takes place within the territory of the Gaza Strip. The military government that previously existed in that territory was abolished by decision of the government, and Israeli soldiers are not present in that area on an ongoing basis and do not direct what goes on there. Under these circumstances, the State of Israel bears no general obligation to concern itself with the welfare of the residents of the Strip or to maintain public order within the Gaza Strip, according to the international law of occupation. Israel also has no effective ability, in its current status, to instil order and manage civilian life in Gaza. Under the current circumstances, the primary obligations borne by the State of Israel with regards [sic] to the residents of the Gaza Strip are derived from the state of armed conflict that prevails between it and the Hamas organization which controls the Gaza Strip; its obligations also stem from the degree of control that the State of Israel has over the border crossings between it and the Gaza Strip; and also from the situation that was created between the State of Israel and the Gaza Strip territory due to years of Israeli military control in the area, as a result of which the Gaza Strip is at this time almost totally dependent on Israel for its supply of electricity."20

Whatever one's view of the main substantive part of the Supreme Court's verdict in this case, the specific proposition that the rules relating to occupation continued in the situation after September 2005 (which was only one plank of the petitioners' case) would appear difficult to sustain granted the traditional rules about occupation with their strong emphasis on the factual basis of a continuing presence on the ground.

19 Petition of 28 October 2007 submitted by Jaber al-Basyuni Ahmad and eleven other petitioners (most of which were Israeli and Palestinian NGOs) to the Supreme Court of Israel, Case No. HCJ 9132/07, paragraph 63 (referring also to another case in which similar issues had been raised). The petitioners sought an injunction to stop Israeli restrictions on the supply of electricity and fuel to Gaza, and Israeli sanctions against the civilian population. Text available at the website of one of the petitioning organizations, www.gisha.org, under "Court Documents."

20 High Court of Justice, Verdict in the case of Jaber al-Basyuni Ahmad et al. v. The Prime Minister and the Minister of Defence, Case No. HCJ 9132/07, Session of 27 January 2008, paragraph 12. Unofficial translation supplied by Gisha available at $w w w$. gisha.org. 


\section{CONCLUSION}

The preceding analysis suggests that the question of how an occupation ends is more complex in practice than it is in treaty provision and legal theory. It also raises two general questions about the ending of occupations:

1. Does international society have institutions able to determine objectively whether an occupation has terminated? A wide variety of decision-making bodies and courts has been involved in taking decisions about the status of occupied territory, including the UN Security Council, the UN General Assembly, the International Court of Justice, the European Court of Human Rights, and also national courts. It seems improbable that any single decisionmaking body will come to be viewed as having pre-eminence over all the others in this matter.

2. Can the application of the rules relating to military occupation be separated from the politically contentious question of the designation of territory as occupied? Some treaty provisions and practice point in this direction, as do the terms of Security Council Resolution 1546 of 8 June 2004 on Iraq. This is a question that needs further exploration. In war, there is some evidence of a tendency to view rules devised for international armed conflicts as having application in conflicts that may be partly or wholly non-international in character. Similarly, the obligations in occupation law may sometimes be best seen as applying in a very wide variety of situations in which foreign armed forces exercise control over foreign societies - whether the situation is described as occupation, liberation, protectorate, international administrative assistance, or anything else. 


\title{
AGENDA AND GUIDING QUESTIONS AIMED AT FRAMING THE DISCUSSIONS
}

\section{DAY ONE}

\author{
THE BEGINNING OF OCCUPATION AND THE MEANING \\ OF EFFECTIVE CONTROL FOR THE PURPOSES OF IHL
}

Working session 1: What are the criteria determining a state of occupation?

What is the exact meaning of effective control for the purposes of IHL? What are the components of the concept of effective control?

Is the test proposed by Article 42 of the 1907 Hague Regulations still valid/sufficient?

Working session 2: The constitutive elements of effective control (1st part)

\section{MILITARY PRESENCE}

Is military presence on the ground a prerequisite for the purpose of the 'effective control' test? Can military presence outside the boundaries of the territory concerned, over its airspace or in its territorial waters or a combination thereof, be considered effective control?

Is it possible for effective control to exist without military presence on the ground? What would be the consequences thereof on the nature and extent of the States' obligations and rights under IHL and occupation law in particular? What other elements might be required to establish effective control in the absence of military presence?

\section{THE EXERCISE OF AUTHORITY}

How should the notion of authority found in Article 42 of the 1907 Hague Regulations be defined? What would be the characteristics of this authority?

Is the test for application of occupation law whether the occupying power has the ability to exert authority or whether it does so in practice, or a combination of both?

Does the authority established by the occupant over the occupied territory need to be absolute or can it be relative? How should the first condition of the test proposed in Section 11.3 of the UK Manual of the Law of Armed Conflict ${ }^{1}$ be interpreted?

Working session 3: The constitutive elements of effective control (2nd part)

\section{TEMPORAL AND TERRITORIAL SCOPE}

Is duration an element to be taken into account in establishing effective control? Is there a minimum duration required for the foreign forces to be considered the occupying power? Does duration affect the occupying power's obligations? 
What is the territorial scope of the notion of effective control? How does the degree of authority exerted affect this territorial scope?

\section{CONSENT}

Article 42 of the 1907 Hague Regulations refers to the notion of a "hostile army." Therefore, the notion of consent is central to the concept of occupation. How would you define the notion of consent for the purposes of effective control? Which authority could legitimately consent to the foreign forces' presence? In the absence of local authority, would effective control exerted by foreign armed forces in itself amount to occupation?

\section{INDIRECT EFFECTIVE CONTROL}

Could a party to a conflict be considered the occupying power if it exercises indirect effective control over a territory (i.e. overall control over an authority, which exercises effective control over the territory)?

\section{Working session 4: From invasion to occupation}

What are the IHL obligations binding upon an invading army? Effective control being a question of degree, when would it be precisely established as the result of the invasion phase?

Is the threshold of applicability different under the 1907 Hague Regulations and the Fourth Geneva Convention? How do you interpret Pictet's position? He adopts - for the purposes of the Fourth Geneva Convention - a broader definition of the term 'occupation,' so that the kinds of protection set out in Part III, Section III of the Convention could be afforded to individuals during the invasion phase.

Is there an alternative to Pictet's position? If so, what would be the legal basis of the protection accorded to individuals during the invasion phase? What protection does IHL offer to individuals in armed conflict when they are neither aliens on the territory of a party to the conflict nor in occupied territory? Must the law be developed to deal with such situations?

\section{DAY TWO}

\section{THE END OF OCCUPATION}

\section{Working session 5}

\section{THE CRITERIA FOR DETERMINING THE END OF OCCUPATION}

Are the criteria for the beginning and the end of occupation identical or can there be additional factors affecting the determination of the end of occupation? What do IHL, the jurisprudence and States' practice say about how occupation ends or should end?

Can an occupation (and all the related legal responsibilities) end at a single moment? When does effective control cease to exist, in particular in the case of progressive phasing out of the occupying power?

\section{SHARING OF AUTHORITY IN OCCUPIED TERRITORY AND THE END OF OCCUPATION}

How does the sharing of competences between the occupying power and the legitimate local authority affect the state of occupation? When would the sharing of competences trigger the end of occupation? Should the nature of the competences retained influence the legal classification of the situation?

Does Article 47 of the Fourth Geneva Convention affect the legal classification in cases of shared authority based on an agreement? When and according to which criteria would such an agreement fall within the ambit of Article 47? Could an agreement based on Article 47 lead to the end of occupation and relieve the occupant from its obligations under occupation law? 
When should the devolution of governmental functions to the legitimate local authority be considered sufficiently effective to end the application of occupation law?

\section{RELATIONSHIP BETWEEN THE WITHDRAWING OCCUPYING POWER AND THE LEGITIMATE LOCAL AUTHORITY}

Does occupation necessarily cease with the withdrawal of the foreign troops? Would your position be the same in the case of partial withdrawal from the concerned territory? What would be the legal situation if the foreign forces, despite their complete withdrawal, were to retain competences over the area without the legitimate local authority's consent?

Is a former occupying power under a legal obligation to hand over all the competences it exerted over the occupied territory in order to end the occupation? Should the end of occupation correspond with the restoration of the local authority's full power?

Does the withdrawing occupying power have any obligation to facilitate the exercise of its functions by the legitimate local authority?

Is the occupying power under an obligation to restore the situation in the territory to that prevailing at the time of the start of occupation?

Under what conditions may the local government end the occupation? Would these conditions differ if the local government had been put in place by the occupying power?

How does occupation end in the absence of any local authority?

Multilateral occupation: A case apart? When does it start? When does it end?

\section{Working session 6}

Should the same criteria apply in case of multilateral military intervention? Does the UN mandate conferred upon the multilateral forces influence the legal criteria determining a state of occupation? If so, to what extent and on what legal basis?

What effect can a resolution of the Security Council have on the classification of a territory as occupied? How should the Security Council assess the local authority's consent to/acceptance of the foreign military presence on its territory?

Who are the occupying powers in case of a multilateral intervention? Can foreign forces participating in a multilateral occupation not be regarded as a "hostile army" for the purposes of occupation law?

If not, what criteria would be used to distinguish occupying forces from other contributing States? Does mere participation/cooperation in the occupation suffice to make contributing States occupying powers? What degree of participation and which activities would lead to these States being regarded, in legal terms, as occupying powers? 


\section{APPENDIX 4}

\section{LIST OF PARTICIPANTS}

1. Prof. M. Bothe, Johann Wolfgang Goethe-Universität, Frankfurt

2. Prof. E. David, Université libre de Bruxelles

3. Prof. G. Fox, Wayne State University School of Law

4. Lt-Gen. (retd) S. Nambiar, Indian Armed Forces, United Service Institution of India

5. Prof. A. Roberts, University of Oxford

6. Prof. M. Sassoli, University of Geneva

7. Dr C. Shamas, Senior Partner, The Mattin Group, Jerusalem/Ramallah

8. Prof. Y. Shany, Hebrew University of Jerusalem

9. Dr D. Shraga, Principal Legal Officer, Office of Legal Affairs, United Nations

10. Col (retd) M.E.F. Supervielle, Judge Advocate General's Corps, US Army

11. Dr M. Zwanenburg, Senior Legal Adviser, Ministry of Defence, Netherlands

12. Prof. Y. Sandoz, Geneva Academy of IHL and Human Rights, Member of the ICRC

13. Dr P. Spoerri, Director for International Law and Cooperation within the Movement, ICRC

14. Mr. L. Colassis, Deputy Head of the Legal Division, ICRC

15. Dr S. Vité, Legal Adviser, ICRC

16. Dr T. Ferraro, Legal Adviser, ICRC 


\section{SECOND MEETING OF EXPERTS: DELIMITING THE RIGHTS AND DUTIES OF AN OCCUPYING POWER AND THE RELEVANCE OF OCCUPATION LAW FOR UN ADMINISTRATION OF TERRITORY 15-16 DECEMBER 2008, GENEVA}

It is widely recognized that Article 43 of the Hague Regulations and Article 64 of the Fourth Geneva Convention constitute the most essential rules defining and delimiting an occupying power's authority in occupied territory. These provisions address the obligation of an occupier to restore and ensure public order and safety in occupied territory and the extent to which the occupier may change local laws and initiate new legislation.

Despite the fact that these provisions were drafted some decades ago and have been subject to various analyses and court decisions, their precise meaning remains unclear. Various conflicting interpretations have arisen, hindering the quest for a coherent approach to occupation law. Citing these central provisions, occupying powers have often justified a very large scope of authority over occupied territories. In other cases, foreign administrators have invoked the obligation to respect local laws in order to minimize their authority and evade their responsibilities under occupation law. This situation is unsatisfactory and work has to be done in this regard to avoid discrepancies in the interpretation and implementation of the law in contemporary contexts of occupation.

Human rights law has also progressively gained importance in situations of occupation and has often been mentioned as a relevant - albeit not exclusive - legal framework. This body of law may impose obligations on parties to an armed conflict or be used as a source of reference for assessing the actions of both external powers and local actors. Arguably, it might also serve as a basis for changing existing local laws or even be used to justify transformative objectives. Addressing the issue of the applicability of human rights law in occupied territories is therefore of the utmost importance at present.

Even if the extraterritorial application of human rights law has been generally accepted (despite some controversy), questions remain over the extent to which an occupying power must implement human rights law during occupation. In addition, the legal interplay between this body of law and occupation law needs to be carefully examined. This is particularly important for subjects on which IHL is silent or vague, such as the right to education and the right to form trade unions. The ICJ has already provided some guidance on the issue $;^{2}$ nevertheless, the exact nature of the relationship between occupation law and human rights law deserves more elaboration.

Another issue is that of "transformative occupation." It has been widely suggested, in the light of the basic principles regulating occupation, that the occupying power would not be entitled to bring about changes in the occupied territory or undertake reforms that could not be reversed by the legitimate government once the occupation had ended. Similarly, the transitory character of the rights and duties of the occupying power seems to preclude definitive and large-scale changes to the social, economic or institutional structures of the occupied territory. 
However, there is often a discrepancy between the requirements of the law and the reality of occupation. For example, while preserving the status quo ante was at the core of the legal debates surrounding the occupation of Iraq (2003-2004), this key principle of occupation law appears to be clearly at variance with the ultimate goal of some multilateral operations to overturn a government and alter the institutional basis of its power. To defuse the tension between the occupation law requirement to respect the laws and institutions in place and the perceived necessity, in some instances, of altering the characteristics of the occupied territory in some cases, it has been contended that IHL, and occupation law in particular, should permit such transformative processes. Thus, it might be argued that remodeling the core institutional structures of certain States - be they weak, in collapse or posing a threat to peace and international security - is a legitimate task ascribed to the occupying power. Nevertheless, the question arises whether "transformative occupation" has any basis in law.

Prolonged occupation also raises an entire set of legal questions. Even though IHL contemplates the possibility that an occupation may be protracted, neither the Hague Regulations nor the Fourth Geneva Convention has placed limits on the duration of effective control over a foreign territory. It seems therefore that, under IHL, the occupying power may exercise its authority over an occupied territory for as long as it deems necessary to secure its military interests and impose its terms of peace upon the enemy. However, prolonged occupations place IHL under considerable strain insofar as they call into question some of the underlying principles of occupation law, in particular the provisional character of the occupation and the necessity of preserving the status quo ante. Since neither the Hague Regulations nor the Fourth Geneva Convention specifies any lawful deviation from existing law in such circumstances, many have argued that prolonged occupation necessitates specific regulations for guiding responses to the practical problems arising from long-term occupation.

In addition to questions concerning occupations by States, a number of legal issues, of potential consequence for occupation law, have been raised by the recent international military operations in Kosovo and East Timor. Given the similarities between occupation and the international administration of foreign territory, the relevance and adequacy of occupation law for the latter situation has come to the fore of the legal agenda.

This subject has assumed great importance not only as scholarly issue but also as an operational one. In fact, the UN has taken on new roles in the administration of foreign territory despite the absence of specific international legal norms for dealing with such situations. Though there are comparatively few operations of this kind at present, the possibility that there may be more in the future should not be discounted, making it essential to define the norms that should apply thereto.

The basic question of the de jure applicability of occupation law to UN administrations is probably the first one that should be dealt with. Given our understanding of when an occupation begins and ends, some argue that a UN operation could never amount to an occupation for the purposes of IHL. Others, however, have claimed that, considering the evolving nature of international operations, the possibility of applying, de jure, occupation law to international administration should not be automatically excluded.

Should occupation law be held to apply de jure to UN administrations, the question that will have to be resolved is the relationship between this body of law and the Security Council resolution defining the mandate of the international administration. A range of opinions is available on this question. On the one hand, it has been argued that Security Council resolution would simply displace all of occupation law and become a special legal regime unto itself. On the other hand, there is a view that the Security Council can supersede occupation law only to a certain extent and that even then this must be stated very explicitly in the resolution. The merits of these competing arguments will have to be evaluated to determine more precisely the influence of occupation law on UN administration.

Given the difficulties posed by their de jure applicability to UN or other territorial administrations, the question arises whether these specific norms of occupation law could be applied de facto. In fact, both the UN and some national contingents involved in international territorial administration have already looked to occupation law either for rules to apply de facto, or for inspiration for policy-making. 


\section{PART ONE: DELIMITING THE RIGHTS AND DUTIES OF AN OCCUPYING POWER}

\section{A. ARTICLE 43 OF THE HAGUE REGULATIONS OF 1907 AND ARTICLE 64 OF THE FOURTH GENEVA CONVENTION AS KEY PROVISIONS FOR ASSESSING THE SCOPE OF AN OCCUPYING POWER'S RIGHTS AND DUTIES}

In an introductory presentation, ${ }^{3}$ one expert analysed the contemporary meaning of Article 43 of the Hague Regulations (abbreviated as THR for the rest of this section) and Article 64 of the Fourth Geneva Convention (abbreviated as GCIV for the rest of this section), ${ }^{4}$ which are the key provisions delimiting the rights and duties of an occupying power. The presentation provoked lively discussions on the content of those provisions, the interrelationship between them, and the limits set by occupation law on an occupant's powers, particularly its ability to enter into treaty relationships.

\section{The content and scope of Article 43 of THR and Article 64 of GCIV}

A consensus developed very quickly among the experts that Article 43 of THR combined with Article 64 of GCIV gave the occupying power a very broad grant of authority over occupied territory. Moreover, although in the past it was understood that occupying powers were permitted to interfere very little, if at all, in the life of the occupied territory, current IHL obligations and recent practice suggest that occupants have adopted a much more interventionist approach and are involved in almost all aspects of life in the occupied territory. Most of the experts agreed that Article 43 of THR should be interpreted broadly to allow the occupying power to fulfil its duties under occupation law, in particular the administration of the occupied territory for the benefit of the local population, while ensuring the security of its own armed forces.

The discussions then dealt with the core of those two central provisions. Some experts asserted that while Article 43 of THR seemed to contain two interrelated parts (the obligation to restore and maintain public order and security, and the duty to respect the laws in force in occupied territory), the travaux préparatoires of this instrument and subsequent State practice indicate that in fact, Article 43 consists of two separate obligations that broadly define the occupant's scope of authority under IHL. The experts argued that the first part, the positive obligation to restore and maintain public order and safety, was essentially aimed at averting the breakdown of civil life in occupied territory and entailed - as a minimum - an obligation to take necessary measures to stop or prevent such a collapse. The second part of Article 43 of THR constituted a general rule about the legislative powers of the occupant.

However, in the course of the debates, some of the experts argued that those two obligations were not in fact so sealed off from each other. In their view, the first part of Article 43 of THR helped identify the subjects on which the occupying power could legislate under the provision's second part.

Some experts then went on to interpret the clause "restore and ensure public order and safety" contained in the first part of Article 43 of THR. They declared that the English version differed substantially from the authoritative French text, which referred to the restoration and

\footnotetext{
This presentation was largely inspired by the speaker's writings. See, notably, M. Sassolì, "Legislation and maintenance of public order and civil life by occupying powers," European Journal of International Law, Vol. 16, No. 4, 2005, pp. 661-694.

4 Article 43 of THR provides the following: "The authority of the legitimate power having in fact passed into the hands of the occupant, the latter shall take all the measures in his power to restore, and ensure, as far as possible, public order and safety, while respecting, unless absolutely prevented, the laws in force in the country." Article 64 of GCIV states: "The penal laws of the occupied territory shall remain in force, with the exception that they may be repealed or suspended by the Occupying Power in cases where they constitute a threat to its security or an obstacle to the application of the present Convention. Subject to the latter consideration and to the necessity for ensuring the effective administration of justice, the tribunals of the occupied territory shall continue to function in respect of all offences covered by the said laws. The Occupying Power may, however, subject the population of the occupied territory to provisions which are essential to enable the Occupying Power to fulfil its obligations under the present Convention, to maintain the orderly government of the territory, and to ensure the security of the Occupying Power, of the members and property of the occupying forces or administration, and likewise of the establishments and lines of communication used by them."
} 
maintenance of "l'ordre et la vie publics." The experts argued that Article 43 of THR, as reflected in the French text, imposed on the occupying power an obligation "to restore public order and civil life" (emphasis added), ${ }^{5}$ whose meaning was much broader than the term "public safety" used in the English version.

One participant declared that while "public order" meant security or general safety, the meaning of "civil life" had been described in the International Declaration concerning the Laws and Customs of War (Brussels, 27 August 1874) as including the social functions and ordinary transactions that constitute daily life in the occupied territory. This expert argued that not only was this broad interpretation of the concept of "civil life" still relevant, but in fact it was the only interpretation that corresponded to the evolution of the occupying power's role over time. Consequently, the role of an occupying power could no longer be regarded as that of a disinterested invader but rather as that of a full-fledged administrator. Another expert even contended that the ever-increasing role of the occupying power in occupied territory had been expressly recognized by Article 64 of GCIV, which replaced the negative test proposed in Article 43 of THR ${ }^{6}$ with positive authorization, whereby the occupant could subject the population of the occupied territory to provisions that are essential to enable it to exert its functions under occupation law.

Following the discussions on the notion of civil life, the experts set out to clarify the term "unless absolutely prevented," from the second part of Article 43 of THR, which is generally interpreted as delimiting the scope of the occupant's legislative powers. Some experts asserted that the term referred to the exception of necessity. They argued that the clause should not be restricted to military necessity, but should be interpreted as referring to "necessity" broadly defined, which would justify broadening the basis for changing local laws. The experts argued also that the concept of necessity consisted of three strands - mili-

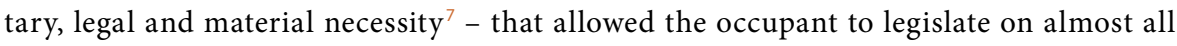
aspects of life in the occupied territory.

One participant held that a construction that confined the term "unless absolutely prevented" to the military interest of the occupying power would appear to be far too narrow, if not actually incorrect, since a contemporary interpretation of the term in question would permit the foreign forces to change the existing laws in the occupied territory when necessary for the welfare of the local population. Finally, according to one participant, although the occupant had an obligation to maintain the laws in force in the occupied territory, Article 43 of THR allowed it to modify, suspend or repeal them when the necessity arose.

Despite these clarifications, a few participants asserted that the term "unless absolutely prevented" should not be interpreted as granting the occupying power a blank cheque for legislation. Therefore, the notion of necessity for the purposes of Article 43 of THR required further elaboration. To that end, it was argued that Article 64 of GCIV helped in delineating more precisely the meaning and the scope of the term "unless absolutely prevented." The experts held that Article $64 \$ 2$ of GCIV should be viewed as an amplification of Article 43 of THR insofar as it provided for a more accurate meaning of the concept of necessity stemming from the term "unless absolutely prevented." Therefore, following Article $64 \$ 2$ of GCIV, the concept of necessity for the purposes of Article 43 of THR would encompass the duty of the occupant to fulfil its obligations under GCIV, ${ }^{8}$ maintain orderly government in occupied territory, and preserve its ability to ensure its own security. In these three areas, the occupying power could change the pre-existing legal system in occupied territory and issue its own legislation. In others words, Article $64 \S 2$ of GCIV posited some clear limits to the general rule on the occupant's legislative powers set out in Article 43 of THR.

The experts unanimously agreed that the obligation contained in Article 43 of THR was one of means and not of results.

Article 43 of THR states the following: "The authority of the legitimate power having in fact passed into the hands of the occupant, the latter shall take all the measures in his power to restore, and ensure, as far as possible, public order and safety, while respecting, unless absolutely prevented, the laws in force in the country" (emphasis added).

7 For an elaboration of these concepts, see infra the discussions dealing with Article $64 \$ 2$.

8 One expert argued that the reference to the fulfilment of the occupant's obligations under GCIV should be interpreted more broadly, so that it included not only all the IHL obligations, but also the occupant's obligations under public international law in general. 
The fact that Article 64 of GCIV expressed in a more detailed form the terms of Article 43 of THR showed how important the relationship between those two provisions was for delimiting the occupier's rights and duties. One expert brought up the possibility of cross-interpretation, arguing that the two provisions were so intermeshed that it would be a mistake to separate them. However, another participant proposed focusing solely on Article 64 of GCIV insofar as it was the most contemporary expression of lex lata in relation to the scope of the occupant's main powers under IHL. This proposal was turned down by a majority of the experts, who declared that one could not fully understand the scope of Article 43 of THR without Article 64 of GCIV and vice versa. In fact, while Article 64 of GCIV was a useful tool for interpreting Article 43 of THR, the latter was also important for clarifying the meaning of the former. In this regard, one expert referred to the notion of "penal laws" included in Article $64 \$ 1$ of GCIV and, more generally, to the meaning of the term "legislation" under those interrelated provisions. ${ }^{9}$ The expert emphasized that the ability of the occupying power to suspend or repeal local legislation should not be limited to "penal laws" as indicated plainly by Article $64 \$ 1$. Instead, this ability had to be extended to laws in general - decrees, ordinances, and court precedents, as well as administrative regulations and executive orders - because Article 43 of THR referred to "the laws in force in the country" and not only to "penal laws." Thus, Article 43 of THR shed some light on the meaning of Article 64 of GCIV and reinforced the need to interpret the occupant's rights and duties in the light of both provisions.

In this connection, a majority of experts drew attention to the broader complementarity between THR and GCIV. ${ }^{10}$ One expert pointed out that this complementarity was explicitly recognized in Article 154 of GCIV, which states: "In the relations between the Powers who are bound by the Hague Conventions respecting the Laws and Customs of War on Land, whether that of 29 July 1899, or that of 18 October 1907, and who are parties to the present Convention, this last Convention shall be supplementary to Sections II and III of the Regulations annexed to the above-mentioned Conventions of The Hague." According to the experts, that provision was evidence of the interrelation between THR and GCIV and implied that one could not understand the occupying power's scope of authority without considering the two instruments together.

Having clarified some elements of Article 43 of THR and Article 64 of the GCIV, the experts then tried to define more precisely the scope of the occupant's legislative powers. They almost unanimously agreed about the ability of the occupying power to legislate to fulfil its obligations under GCIV or to enhance civil life in occupied territory. ${ }^{11}$ Their opinions were more divided on the subject of whether occupation law authorized the foreign administration to legislate with a view to implementing human rights law in the area under its effective control.

In this regard, one expert pointed out that a proposal aimed at giving the occupying power the right to repeal local legislation contrary to international human rights law had been rejected during the negotiations that led up to GCIV. The expert also pointed out that the rejection of this, Mexican, proposal may be attributed mainly to the embryonic character of human rights law at the time of the negotiations. Considering the development and importance of human rights law today, and the recognition of its applicability in situations of occupation, ${ }^{12}$ one could now convincingly argue that the occupying power would be "abso-

9 In addressing the issue of the interaction between Article 43 of THR and Article 64 of GCIV, some experts dwelt on the structure of the latter. In particular, they pointed out that the text of Article $64 \$ 2$ seemed to authorize the introduction of new legislation for the purpose of maintaining orderly government in occupied territory, while Article $64 \$ 1$ did not permit the repeal or suspension of existing penal laws. In this regard, one expert argued that the two $₫$ of the provision should allow for the same exception. Therefore, the occupant should be able to suspend or repeal existing laws in occupied territory on the basis of the "maintenance of orderly government" exception set out in Article 64\$2. In addition, it was argued that the principle of lex posterior derogate legi anteriori would permit the repeal of local laws that would prevent the occupant from discharging its obligation to maintain orderly government in occupied territory.

10 For instance, THR lays down provisions regulating taxation in occupied territory, the management of public property and the requisitioning of private property, whereas GCIV does not.

11 The capacity of the occupant to legislate, with a view to enhancing civil life in occupied territory, was discussed in depth in the working session devoted to prolonged occupation.

12 See, for instance, ICJ jurisprudence, notably the advisory opinion of 9 July 2003 on the Legal Consequences of the Construction of a Wall in the Occupied Palestinian Territory and the ICJ decision of 19 December 2005 on Armed Activities on the Territory of the Congo (Democratic Republic of Congo v. Uganda). 
lutely prevented" from respecting local legislation contrary to this body of law. Furthermore, some experts contended that the implementation of human rights law in occupied territory was not only legitimate but also very relevant where occupation law was silent, for instance, on questions such as freedom of opinion and freedom of the press, or vague, such as on the right to education or the right to health.

During the discussions, the experts almost unanimously agreed that human rights law laid down obligations that occupying powers were bound to respect vis-à-vis the local population. ${ }^{13}$ One participant stated that human rights obligations to which States had committed themselves contained three components: the obligation to respect, to protect and to fulfil. The obligation to respect meant that occupying powers had to refrain from interfering with or curtailing the enjoyment of human rights unless authorized by occupation law. The obligation to protect required the occupying powers to defend individuals and groups against human rights violations. The obligation to fulfil required occupying powers to take positive measures to facilitate the enjoyment of basic human rights. Although the participants agreed that the obligations to respect and protect would not raise major difficulties, some of them suggested that the obligation to fulfil could create problems in situations of occupation, since it would require granting the occupying power considerable licence for its implementation. Further discussions suggested that the obligation to fulfil, as derived from human rights law, could enable the occupying power to go beyond what it was permitted to do under occupation law. Some participants made it clear that, should such leeway exist under occupation law, the resulting changes should be absolutely necessary under the occupying power's human rights obligations and should stay as close as possible to local standards as well as to local cultural, legal, institutional and economic traditions.

\section{The ability of the occupying power to enter into treaty relationships}

One expert launched the discussion by quoting a document issued by the Swiss Federal Department of Foreign Affairs:

"L’Accord entre la Suisse et l'Irak sur la garantie des risques à l'exportation a été approuvé par le Conseil fédéral. Dans ce contexte, la question se pose de savoir si l'Autorité provisoire de la coalition est bien compétente pour conclure, au nom de l'Irak, des accords internationaux.

En droit international, le principe est qu'un État occupant dispose du pouvoir légal dans le pays qu'il occupe (article 43 de la Convention de La Haye de 1907). Cela signifie en particulier que la puissance occupante peut promulguer des lois ou conclure des accords internationaux au nom de l'État occupé"14 (emphasis added).

The position expressed in that document triggered numerous reactions among the experts, a majority of whom cast doubt on the occupying power's right under occupation law to conclude treaties on behalf of the occupied territory.

First, a majority of the experts were of the opinion that occupation law did not bestow upon the occupying power the authority to enter into treaty relationships on behalf of the occupied territory. In this regard, one expert referred to the Wimbledon case in which the Permanent Court of International Justice had stated that the conclusion of treaties was precisely one of the attributes of sovereignty. ${ }^{15}$ Since the occupying power had no sovereign title over the occupied territory, the logical inference to be drawn from this piece of jurisprudence would be that the occupant could not enter into treaty relationships on behalf of the ousted government. One expert added that whereas sovereign States could conclude treaties

13 However, one expert expressed serious doubts about the applicability of certain of the occupant's human rights law obligations in occupied territory, in particular under the International Covenant on Civil and Political Rights, based on that instrument's lack of extraterritorial reach.

14 Lucius Caflish, 'La pratique Suisse en matière de droit international public 2003. Note de la DDIP du 15 décembre 2003 Document inédit. 'Compétence de l'État occupant de conclure des accords internationaux pour le compte de l'État occupé" (2004) 5 Revue Suisse de droit international et de droit européen 661, at 663-664.

15 Case of the S. S. Wimbledon, 1923, PCIJ, Series A, No.1. 
the occupying power would need a norme habilitatrice (enabling rule) to do so on behalf of the occupied State. According to this expert, occupation law did not provide for such an enabling rule. Therefore, the occupying power could not invoke this body of law as a legal basis for the conclusion of treaties with third parties on behalf of the occupied territory.

Second, it was noted that treaties concluded by the occupying power could not be unilaterally changed by the occupied State in the future and could have legal consequences long after the foreign forces' complete withdrawal. This would appear to sharply contradict the provisional character of occupation and the fact that measures taken by the occupying power had to be commensurate with the duration of the occupation. Arguably, this problem could be solved with a clause limiting the validity of the treaty to the duration of the occupation. However, one expert pointed out that it would be a radical departure from conventional practice under the law of treaties to impose temporal restrictions on the validity of an international agreement.

Another expert drew attention to the fact that the temporary character of occupation was a practical obstacle to the occupant's ability to conclude treaties; he said that, apart from the Swiss example cited above, no State practice in support of an occupant's treaty-making power could be found. In this regard, he was also emphatically of the opinion that the international agreements signed by the UN mission in Kosovo, referred to in the course of the debates, could not be taken as references and could not be said to represent an emerging practice in relation to an occupying power's ability to enter into treaty relationships. In fact, such UN practice should be regarded as exceptional insofar as the UN administration of Kosovo could not be viewed as an occupation within the meaning of IHL, and since such agreements were valid only for the duration of the UN administration.

Third, some experts pointed out that, under occupation law, foreign forces could occupy a territory completely or partially. ${ }^{16}$ In a partial occupation, the occupied State would continue to carry out governmental functions over the unoccupied parts of its territory and - as occupation will not do away with its status as a subject of international law - would remain entitled to enter into international agreements despite the presence of foreign forces on its territory. In this regard, it was underscored that should occupation law authorize the occupying power to enter into treaty relationships, it could lead to an absurd situation in which two authorities would be able to conclude treaties for the same State, resulting in an unacceptable amount of legal insecurity.

Fourth, if an occupying power were able to conclude treaties on behalf of the occupied territory, it would raise an important question: Who would be entitled to sign such agreements? Would it be the foreign administration per se, the military commander of the occupying forces or the occupying power's government? Further, would it be necessary for the legislative body of the occupying power to endorse an international agreement whose effects were designed to apply solely in the occupied territory? One expert pointed out that these essential procedural issues did not find any answer within IHL instruments and doubted that any guidance regarding the conclusion of treaties by the occupant on behalf of the occupied territory could be found either in other pertinent bodies of law ${ }^{17}$ or in State practice. However, this expert said, should the conclusion of international agreements appear necessary for the administration of the occupied territory, the military commander of the occupying forces or the administration set up for implementing IHL obligations would, by default, be the organs logically entitled to sign such agreements.

Although most of the experts contested the occupying power's right to enter into treaty relationships on behalf of the ousted government, some participants maintained that nothing under occupation law would prevent the occupant from concluding treaties in its own name for the purposes of fulfilling its duties under IHL, in particular if the administration of the occupied territory so required. One expert even expressed the need for a certain flexibility

6 In addition, it was emphasized that occupation was always a very fluid situation subject to various changes, including changes in the geographical boundaries of the occupation, which would make it difficult to delimit the territorial effects of treaties signed by the occupying power on behalf of a territory under partial occupation.

17 Including the occupying power's domestic law. 
concerning the means available to the occupying power for discharging its obligations under occupation law and underlined that that necessity could warrant the occupying power's conclusion of treaties. In this respect, the expert stated that the issue was not whether the conclusion of treaties by an occupying power would be possible, but rather the purposes for which the occupying power would be entitled to enter into treaty relationships within the framework of the occupied territory's administration.

Similarly, another expert held that it would not be realistic to think that the occupied territory could be administered in a vacuum and without any international connections. In fact, now, effective administration of occupied territory would probably necessitate the conclusion of treaties with third parties, in particular in situations of prolonged occupation. This expert argued that IHL did not restrict the occupying power's choice of legal means in realizing its duties under occupation law. In this regard, the obligation to restore and maintain public order and civil life, set out in Article 43 of THR, could potentially entail the necessity of signing international agreements with third parties. The expert also asserted that occupation law was more interested in the fulfilment of the occupying power's obligation than in the means used to that end. Consequently, the expert suggested, there should be no a priori rule against the occupying power negotiating or renegotiating agreements with third parties, when it does so to discharge its obligations under occupation law.

\section{B. THE ROLE OF HUMAN RIGHTS LAW IN OCCUPIED TERRITORY}

\section{The applicability of human rights law in occupied territory}

Even though the issue had already been addressed at great length in legal doctrine, many of the experts were of the view that the question of the applicability of human rights law in occupied territory still had importance, given certain States' stance on the matter, and because it remained a prerequisite for further discussions on the core human rights obligations incumbent upon the occupying power.

Almost without exception, the experts asserted that the applicability of human rights law to situations covered by IHL, in particular military occupation, should be widely recognized. They said that this position had been confirmed by a considerable amount of international practice and jurisprudence, particularly that of the ICJ in its 2004 advisory opinion on the Wall in the Occupied Palestinian Territory and in its 2005 decision in the case of Democratic Republic of the Congo v. Uganda. ${ }^{18}$

One expert argued that the applicability of human rights law in a territory subject to effective foreign control could be inferred from Article 4 of the International Covenant on Civil and Political Rights (abbreviated as ICCPR for the rest of this section), which allowed for derogation in times of public emergency. Since occupation is a form of international armed conflict and armed conflict has to be included within the meaning of "public emergency" for the purposes of this Article, it was logical to conclude that the ICCPR was also meant to apply in situations of occupation. However, the participants acknowledged, the extraterritorial application of human rights law was still a source of controversy for a few scholars and for certain States, as the Israeli position concerning the applicability of human rights law in occupied Palestinian territory illustrated.

Nevertheless, one participant challenged the applicability of human rights law in occupied territory, in particular the applicability of the ICCPR. This expert argued that the ICCPR's plain language confined its application to the territory of the States Party and did not foresee any extraterritorial reach. The expert added that this language had been introduced into the treaty expressly, because some States considered it very difficult - if not impracticable - to apply the full breadth of the ICCPR in occupied territory. The expert said that he was not ignoring the views that had been expressed by so many experts about the extraterritorial 
application of human rights law; however, he did want to draw attention to the fact that - at least for some States - the matter remained unsettled.

Another expert advocated taking the middle ground. He did not support the view that human rights law was wholly inapplicable in extraterritorial military operations, but thought that its applicability would always depend upon the scope of application of the human rights law instrument from which the rights in question were drawn. Consequently, the applicability of human rights to situations of occupation should be subjected to a ruleby-rule analysis.

Following this suggestion, the experts addressed the legal standards in force in order to determine the extraterritorial application of human rights law. It was noted that there was no uniformity in this respect. Rather, instruments of human rights law had different scopes of application relying on various legal tests, which the experts tried to list.

One participant commenced by identifying three different standards: (1) effective control; (2) State agent authority; and (3) voluntary acceptance of the extraterritorial application of human rights law.

Another expert suggested four other legal bases for applying human rights law in occupied territory. First, the treaties to which the occupying power was a party, such as the International Covenant on Economic, Social and Cultural Rights (abbreviated as ICESCR for the rest of this section) and the ICCPR, might apply extraterritorially. Second, an instrument of human rights law could be applicable by virtue of its having been ratified and implemented domestically by the ousted government. Third, the applicability of human rights law in occupied territory could be inferred from an evolutive interpretation of Article 43 of the Hague Regulations and Article $64 \$ 2$ of the Fourth Geneva Convention, as specified by the ICJ in its decision in the case of Democratic Republic of the Congo v. Uganda. Fourth, and most importantly, human rights would apply because they were deemed part of customary international law.

The experts did not dispute the first three of these four legal bases, but the reference to the customary nature of human rights norms to justify their extraterritorial reach created some controversy. Many participants challenged the view that the customary nature of a human right would necessarily entail its extraterritorial applicability. These experts maintained that a customary norm retained its scope of application and therefore its geographical reach. Affirming that a norm was of a customary nature did not create an obligation for the State party to the relevant instrument to apply it beyond its conventional scope of application. Otherwise, one participant said, every State would be responsible for ensuring that human rights law was respected beyond its borders.

Two participants then proposed a three-stage test to determine whether human rights law would apply in occupied territory. First, the specific human right or obligation at stake had to be determined. Second, the instrument containing such a right or obligation had to be identified. Third, one had to ask whether the instrument in question created an obligation for an occupying State to apply it in foreign territory subject to its effective control. For these participants, only the fulfilment of this three-pronged test would enable the identification of the human rights framework that would apply in a particular situation of occupation.

Although they recognized the pertinence and validity of all the approaches that had been proposed, some experts insisted on the importance of the international consensus that was developing around two standards for determining the extraterritorial applicability of human rights law: the 'effective control' test and the 'State agent authority' test. According to these experts, these two standards had been established over time by international and regional jurisprudence and had been overwhelmingly endorsed by legal doctrine.

The discussions then turned to the manner in which human rights law would apply in occupied territory. A majority of the experts recognized that situations of armed conflict and occupation would not usually allow for the full application of human rights law; they put 
forward a few proposals aimed at circumscribing the material scope of application of human rights law in occupied territory.

The discussions on this issue resulted in the emergence of a three-faceted test. According to this test, one would have to distinguish between positive and negative human rights obligations, ${ }^{19}$ short-term and long-term occupation, ${ }^{20}$ and civil and political rights versus economic, social and cultural rights. ${ }^{21}$

\section{The relationship between IHL and human rights law}

Most of the experts agreed that a framework of interpretation was required to determine how human rights law and IHL could apply together. The discussions that followed on this subject were dominated by references to terms such as lex specialis and complementarity.

The experts defined lex specialis as a principle according to which, in choosing between two rules, the one that was more specific and most pertinent should be given precedence, since a special rule would usually give a clearer answer to the question at hand than a general one.

Traditionally, the principle of lex specialis has been regarded as a tool to resolve conflicts between norms. However, some experts suggested, the purpose and scope of the principle had been broadened so that it could be used to clarify the interplay between human rights law and IHL, even in the absence of conflicts between norms. In this way, these experts argued, the lex specialis principle could be invoked as the more specific norm supplementing the more general one without contradiction: lex specialis and lex generalis simply added to each other.

Consequently, these experts suggested, the lex specialis principle could be interpreted in two ways. First, it could be used as a device to interpret human rights law in the light of IHL. Second, the conflict-solving dimension of the principle could be used to promote the primacy of IHL over human rights law and the idea that in situations of armed conflict (including occupation), IHL should be applicable to the exclusion of human rights law.

In this regard, one expert asserted that, as a whole, IHL was the lex specialis in situations of occupation. It was emphasized that occupation law was the body of law specifically dealing with occupation and, therefore, had taken the specific characteristics of this situation for all its norms. Human rights law - because it had to apply to so many different situations - was formulated in much looser terms and could not be viewed as the lex specialis for situations of occupation.

Another participant proposed a slightly subtler approach. He said that the principle of lex specialis was not exclusionary, but rather a "right of way principle," in which IHL generally had the more dominant position. Wherever there was a specific rule of IHL, it would govern the matter. Where IHL was vague, human rights law could be used as an important tool for interpreting the pertinent IHL provisions. In the event that there was no specific rule of IHL on a particular subject, human rights law would apply, but would be construed in the light of IHL. ${ }^{22}$

In this regard, one expert asserted that the lex specialis argument did not mean that IHL definitively precluded human rights law. One logical consequence of the establishment of IHL as the specific body of law in situations of armed conflict and occupation was that

9 One expert identified a clear trend towards finding negative human rights obligations applicable everywhere, irrespective of the degree of control, while positive obligations were highly dependent on the degree of control. In particular, it was explained that most of the findings of extraterritorial application of the ICCPR were made in the context of negative obligations as the work of the Human Rights Committee showed.

20 Some experts held that the relevance and importance of human rights law largely depended on the duration of the occupation. They said that in short-time occupation, the core of human rights obligations corresponded to the obligations set out under IHL, thus significantly limiting the benefits conferred by human rights law. However, it was asserted that during longer periods of occupation, human rights law became increasingly important and provided for more detailed answers than IHL norms.

21 The latter distinction was justified by the difference between the ICCPR and ICESCR's scope of application, by the possibility granted by the ICCPR, unlike the ICESCR, of derogating from certain of its provisions, and by the nature of the rights involved (immediate effect of ICCPR norms vs progressive realization of ICESCR provisions).

22 Another participant raised this question: Did IHL's silence on a particular subject invite the application of human rights law or could such silence be regarded as meaningful? 
human rights law could not be applied in an unqualified manner in such circumstances. Rather, human rights law would need to adjust to the specific situation of occupation. Consequently, human rights law should be applied alongside IHL in international armed conflict, including occupation, but in a manner respecting the balance set by the lex specialis between humanitarian considerations and military necessities. The expert warned against concluding too hastily that human rights laws stepped in automatically and unrestrictedly whenever IHL was vague on a certain subject.

However, other participants challenged the position that IHL was, by nature, the lex specialis in situations of occupation. They asserted that the interrelationship issue could not be settled by a general analysis of the two legal regimes. Instead, only a rule-by-rule approach would enable one to determine which norm was the lex specialis in relation to the other. Neither of the two bodies of law in question would be by definition more specific. Determining which of two competing sets of rules was more specific should not be done in the abstract; the decision would depend on the precise circumstances in which these rules applied. It was stressed that, in the context of occupation, competition between IHL and human rights laws would arise particularly with regard to administrative detention and judicial guarantees, and when the occupation endured.

A narrow majority of the experts supported examining the interaction between IHL and human rights law based on complementarity and cross-interpretation. They argued that international instruments had to be interpreted in relation to one another, because public international law was, after all, a coherent system. An interpretation of this kind worked in both directions. Not only could human rights law be interpreted in the light of IHL, as the ICJ's jurisprudence demonstrated, but IHL could also be interpreted in the light of human rights law.

It was contended that one advantage of having recourse to human rights law when interpreting IHL was that human rights law had been interpreted in numerous decisions and opinions, both by domestic courts and international bodies, and therefore constituted a consolidated and reliable corpus juris. It was also contended that such a position also emphasized the fact that IHL and human rights law formed part of a coherent system of international law that should, as much as possible, be interpreted so as to preserve consistency between the norms. In this regard, it was advocated that the principle of lex specialis derogat legi generali be turned into lex specialis compleat legi generali. One expert declared that the principle of lex specialis derogate legi generali would not disappear entirely, but would intervene only when a clear conflict between norms of IHL and human rights law materialized.

\section{The application of economic, social and cultural rights during occupation}

After discussing the points raised by the introductory presentation, the panel dwelt on the application of the International Covenant on Economic, Social and Cultural Rights (abbreviated as ICESCR for the rest of this section) during occupation.

One expert challenged the idea that the ICESCR was meant to apply in situations of occupation; however, most of the participants took the view that this instrument could be relevant during an occupation.

Some of the participants asserted that the nature of the obligations enshrined in the ICESCR, as well as the flexibility that the instrument allowed for their implementation, tended to facilitate application of the ICESCR during occupation. It was emphasized by these experts that the ICESCR recognized that its rules were to be applied over time and that their application could go through different stages by virtue of their very nature. This flexibility was deemed particularly important during a period of occupation since it would permit the implementation of the ICESCR to be adjusted to the realities of the situation. For instance, some experts said, a considerable part of the infrastructure might be destroyed by military operations during an invasion, and afterwards the occupied territory might still be subject to considerable instability: this would significantly limit the ability of the occupying power to meet all of its legal obligations. The experts argued that after the situation in the occupied territory had stabilized and the occupying power had 
the opportunity to strengthen its control over the territory, the normative content of the occupying power's obligations would expand. These experts drew attention to the fact that the ICESCR's flexibility permitted these changes in the prevailing situation to be taken into account, which made it an extremely useful instrument for the occupying power.

However, a number of experts stressed that the leeway given to the occupying power by the ICESCR was not unlimited. The progressive realization of economic, social and cultural rights did not mean that the occupying power had a right to wait for the most favourable circumstances before meeting its obligations under the instrument. Such an interpretation would deprive the instrument of its normative content, as the occupying State would be free to decide the extent of its obligations vis-à-vis the occupied population. As one expert emphasized, the position of the United Nations Committee on Economic, Social and Cultural Rights showed that States implementing the ICESCR should adhere to a basic normative threshold, regardless of the circumstances, including those prevailing in occupied territory. ${ }^{23}$

In this regard, some experts affirmed that, despite its intrinsic flexibility, the ICESCR would oblige the occupying power to immediately implement certain core rights. They pointed out that the instrument distinguished between two normative levels: (a) provisions establishing obligations of immediate effect, and (b) provisions establishing obligations to be realized progressively. Consequently, an occupying power bound by the ICESCR would not be able to refer to its programmatic nature in order to delay its application as a whole in the occupied territory. Thus, some participants said, during occupation, these rules formed a normative circle that the occupying authorities had to take into account as soon as they gained effective control over the territory.

According to a number of experts, some of those obligations of immediate effect were referred to explicitly in the ICESCR, ${ }^{24}$ while others had to be inferred. ${ }^{25}$ Further, in Article $2 \$ 1,{ }^{26}$ the ICESCR obliged the occupying power to adopt specific measures to promote its full application, whatever the nature of the obligations concerned. Passivity in this regard would be contrary to the occupying power's commitments as a party to the ICESCR.

Some experts argued that although in some cases the realization of economic, social and cultural rights could take place over time, the occupying power had to take steps immediately to achieve these objectives. During periods of occupation, the authorities in place should therefore not refer to the temporary nature of their presence on foreign territory in order to evade these obligations. One expert drew attention to the case of Iraq: there, the Coalition Provisional Authority justified redrafting the labour code of the country on the grounds that, as a State party to International Labour Organization Conventions 138 and 182, Iraq was obliged to "take affirmative steps towards eliminating child labour."

Some experts also pointed out that, despite their inherent flexibility, each of the economic, social and cultural rights had an irreducible normative content that had to be respected in all circumstances, regardless of the country's economic condition, its political situation or its institutional structure. They held that an occupying power would have a core obligation to ensure the realization of at least the minimum essential levels of each of the rights, even in the earliest stage of the occupation. They thus set a limit to the flexibility allowed by Article $2 \$ 1$ of the ICESCR.

The experts then analysed, in the light of the interaction between IHL and human rights law, how the basic principles of occupation law would affect the implementation of the ICESCR in occupied territory.

23 UN Committee on Economic, Social and Cultural Rights, General Comment No. 3: The Nature of States Parties' Obligations (Art. 2, para. 1 of the Covenant), 14 December 1990, paras 9, 10. See also The Maastricht Guidelines on Violations of Economic, Social and Cultural Rights, UN Doc. E/C.12/2000/13, 2 October 2000, No. 8.

24 For instance, the right to receive fair wages and equal remuneration for work of equal value without distinction of any kind.

25 For instance, the right to humanitarian assistance deriving from the right to food.

26 Article $2 \$ 1$ of the ICESCR states: "Each State Party to the present Covenant undertakes to take steps, individually and through international assistance and co-operation, especially economic and technical, to the maximum of its available resources, with a view to achieving progressively the full realization of the rights recognized in the present Covenant by all appropriate means, including particularly the adoption of legislative measures." 
Taking into account the lex specialis principle, one expert argued that the occupying power could only implement economic, social and cultural rights within the limits set by occupation law itself. According to this expert, the application of the ICESCR implied a long-term perspective and the existence of a sovereign power to effect far-reaching social change. The realization of the right to work, for instance, would oblige the occupying power to devise development strategies that would bind the occupied territory's economy for a long time. Occupation law, by contrast, offered resistance to changes of that kind because it was inherently conservative. Its aim, as set out in Article 43 of the Hague Regulations, was to maintain the institutional and legal structures pending a decision on the future status of the territory concerned. Thus, it set a limit to the realization of economic, social and cultural rights. Consequently, some experts argued, occupation law considerably restrained the implementation of the ICESCR; however, they also suggested that the duration of the occupation could play an important role in loosening those restraints. ${ }^{27}$

Other experts suggested that the objectives of occupation law and those of the ICESCR were not so different. They declared that the realization of economic, social and cultural rights did not necessarily imply reforms that would be so radical as to be at odds with the basic premises of occupation law. They said also that the normative balance between occupation law and economic, social and cultural rights could be found only by analysing specific rules of the ICESCR on a case-by-case basis.

The experts then discussed the implementation in occupied territory of two specific rights: the right to food and the right to health. Some of them noted that, from the perspective of human rights law, the right to an adequate standard of living implied that each person must have access to the conditions necessary for his or her individual livelihood. According to the terms of the ICESCR, this essential minimum standard included, in particular, adequate food, clothing and housing, as well as the continuous improvement of living conditions. The ICESCR also recognized "the right of everyone to the enjoyment of the highest attainable standard of physical and mental health." Defining the core of each of those rights, applicable under all circumstances, would therefore, according to these experts, clarify the rules applicable during occupation.

Some of the experts agreed that the right to adequate food under the ICESCR included as an essential element the fundamental right of everyone to be free from hunger. That rule constituted the core of the right to food, which could be violated if, for example, the occupation forces destroyed the civilian population's food stocks or damaged the means of production (for example, by placing mines in agricultural areas, displacing farming or fishing communities, paralyzing the transport network or blocking access to certain basic services). This right would also be violated if the occupying power failed to adopt measures necessary to prevent third parties from carrying out similar practices.

According to this view, the right to food would also require the occupant to adopt certain positive measures to facilitate its realization. The occupying power would therefore be required to set up an effective relief distribution system and take account of the needs of the most vulnerable persons, particularly children, the elderly and the disabled.

With regard to the right to health, some of the experts pointed out that its minimum normative content consisted of elements of health care and preventive measures. It implied, in particular, obligations to guarantee the following: access without discrimination to medicines, medical equipment and medical services; an adequate supply of safe drinking water; and the possibility of obtaining essential medicines as defined by the World Health Organization. Some experts stressed that non-compliance with these obligations could not be justified under any circumstances whatsoever. Consequently, these experts deemed these obligations to be non-derogable.

The same experts also underscored that economic, social and cultural rights complemented occupation law even more efficiently when the occupation was prolonged. They said that 
occupation law remained too general for defining a long-term normative framework. Human rights law, the ICESCR in particular, seemed to be more helpful when the occupation had stabilized and when it tended to persist. Assuming that certain immediate measures would be adopted to cover the essential content of the right to food, for instance, some participants added that the ICESCR also called for a long-term approach for gradually achieving its full realization. Thus, they maintained, once the period of emergency was over, it would no longer be enough for the occupying power to just distribute food to the civilian population. The system of human rights provided for civilians to have access to resources and means that would enable them to ensure their own livelihood. To that end, the foreign administration was required to establish measures with regard to all aspects of the food system, including the production, processing, distribution, marketing and consumption of safe food, as well as parallel measures in the areas of health, education, employment and social security. This obligation meant, in particular, that the administration would be obliged to ensure sustainable management of the natural resources used to produce food.

With regard to the right to health, some experts argued that human rights law would require the authorities to look to the future if the occupation persisted. For example, these authorities would have to devise a public health strategy and plan of action in order to meet their obligation under the ICESCR.

Consequently, in connection with the right to health and the right to food, some experts agued that economic, social and cultural rights made explicit reference to matters that were merely touched on by occupation law. This was evidence of the necessary complementarity between human rights law and IHL, which would ultimately result in enhancing protection for the occupied population. These examples showed that the occupant's obligations were not limited to the minimum defined by IHL, but were broader and had to be viewed from a perspective that encompassed the complementary contribution made by human rights law..$^{28}$

\section{TRANSFORMATIVE OCCUPATION}

\section{Definition and lawfulness of the concept}

This working session began by defining precisely the concept of transformative occupation. The participants, almost without exception, emphasized the importance of the purposive component of the concept and described transformative occupation as an operation whose main objective was to overhaul the institutional and political structures of the occupied territory, often to make them accord with the occupying power's own preferences.

The experts then expressed the need to take a very cautious approach to this concept, which was deemed to be highly controversial and contrary to the basic premises of occupation law. The experts unanimously agreed that transformative occupation as defined above had no legal basis and no justification under current IHL. In particular, as the occupying power had not acquired any sovereign rights over the occupied territory, it would not be entitled to bring about changes in the occupied territory or to undertake reforms that could not be reversed by the legitimate government once the occupation was over. The experts also stressed the point that the transitory character of the rights and duties incumbent upon the foreign administrator precluded it from effecting definitive and large-scale changes in the institutional structure of the occupied territory.

One expert added that the idea behind occupation law was to prevent the occupant from modelling the governmental structure of the occupied territory according to its own needs or perceptions, disregarding the intrinsic characteristics of the occupied society. The experts

28 However, this view was disputed by two experts who stressed that the right to food and the right to health were not good examples, since occupation law contained specific norms pertaining to these very subjects, the interpretation and implementation of which would largely suffice to meet the needs of the occupied population. Another expert agreed that in the case of the rights to health and food, IHL provided enough protection; however, he also stressed that there were other human rights, such as the right to work, the right to form trades unions, and the right to life, which were not protected to the same degree by IHL. 
stressed that regardless of the legitimacy or legality of the operations that led to the occupation, the occupying power could not be considered a neutral entity acting only in the interests of the occupied territory and therefore should not be permitted to engage in institutional reforms.

The experts also called attention to the importance of the conservationist principle at the heart of occupation law, the integrity of which should be respected and promoted. They declared that this principle reflected the dictates of prudence and the basic legal premises on which the international community was built, according to which fundamental decisions about a territory's institutional structure should be made by the legitimate sovereign institutions and not by outsiders such as occupying powers.

Despite the unanimity of the experts about the unlawfulness of transformative occupation for the purposes of IHL, many of them emphasized the need to differentiate between fullfledged transformative projects entailing disruptions of sovereignty and smoother changes aimed at getting the basic infrastructure of the occupied society to work in accordance with the relevant norms of occupation law. They asserted that the unlawfulness under IHL of the concept of transformative occupation should not be interpreted as a general prohibition against effecting changes in occupied territory.

In this regard, many of the experts argued that respect for the conservationist principle did not mean that the situation in occupied territory should be completely frozen for the duration of the occupation. Compliance with the obligation to restore and maintain public order and civil life in occupied territory could, in fact, require certain transformations or changes and oblige the occupant to engage in important reforms. The circumstances that might warrant such changes would include the following: when the local laws in force were contrary to IHL provisions or when they prevented the occupying power from fulfilling its duties under occupation law.

These discussions led the experts to dwell on the circumstances under which certain transformations - even important ones - could be carried out in the course of an occupation.

\section{The conditions under which certain transformations are permissible}

The experts analysed five reasons often put forward to justify transformations during occupation: respect for human rights law; the consent of the local population; the characteristics of prolonged occupation; the case of occupied failed States; and decisions taken by the Security Council.

\section{a. Human rights law}

The experts considered whether human rights law would permit, or even require, specific transformations in occupied territory. Some participants suggested that the recognized applicability of human rights law in situations of occupation, combined with an evolutive interpretation of Article 64 of the Fourth Geneva Convention, could justify making substantial changes in the occupied territory. These experts reminded others that Article 43 of the Hague Regulations and Article 64 of the Fourth Geneva Convention require the suspension or abrogation of oppressive local laws if they hindered the occupying power from discharging its duties under the Fourth Geneva Convention (and by extension of this principle, require the occupying power to implement any other obligations derived from international law, in particular human rights law). To illustrate this point, one expert referred to the existence of local laws sanctioning discrimination against women. Abrogation of these laws would be required in application of Article 64 of the Fourth Geneva Convention, but this would also entail major changes in the occupied society that cannot be interpreted as an aspect of transformative policies pre-planned by the occupying power.

Some experts opposed this broad approach, stating that such latitude for transformation under the guise of human rights law would be too great to be in line with the basic premises of occupation law. They stressed that the difficulty of 
setting limits to the transformations required by human rights law could make the conservationist principle almost nugatory. Since human rights law was essentially an agenda for social reform, the contradictions between the conservationist principle and the implementation of this body of law in occupied territory could become quite problematic. These experts also drew attention to the fact that the application of human rights norms in some societies could be deeply intrusive and/or culturally inappropriate. They concluded that the claims of human rights law should also have their limits in situations of occupation.

Eventually, a majority of the experts agreed that some changes could be effected in the occupied territory to meet human rights standards, provided they did not lead to transformative occupation as previously defined in the course of the debates. While an occupying power could be given a certain amount of flexibility to implement human rights law in occupied territory, that should not be interpreted as giving it a blank cheque to change legislation and institutions in the name of human rights to make them accord with its own legal and institutional ideas.

The experts concluded the discussion on this subject by generally agreeing that there were effectively two factors limiting the carrying out of transformations in occupied territories on the basis of human rights: (1) the conservationist principle should be given precedence; and (2) that human rights law should not be invoked in order to justify transformative occupation. With regard to the first, the experts said that careful thinking would be necessary to determine how the conservationist principle and the implementation of human rights law could coexist in situations of occupation, particularly during a state of prolonged occupation. As for the second, many of the experts concurred that there were various kinds of transformation, some of which may be consistent with the conservationist principle and others not. One expert illustrated this point by pointing out that promoting economic development (which would be permitted, even required under occupation law) was not the same as introducing a completely different style of economy (which would clearly be part of a transformative agenda and would therefore be prohibited under current IHL).

\section{b. The consent of the local population}

The experts then considered whether the local population's consent to specific policies devised by the occupying power could be sufficient to justify transformative occupations, even if there was no legal basis for such transformations under IHL. Some experts said that ascertaining the wishes of the local population on certain important reforms would legitimize transformative objectives pursued by an occupying power. One expert even put forward the idea that the occupying power had a de lege feranda duty to canvass the local population's views on decisions and policies that might lead to important changes in the occupied territory. This expert also argued that this expression of local sentiments would be, in a way, a realization of the principle of self-determination (within its internal meaning) whose importance increased the longer the occupation endured.

However, many participants disputed this. They particularly emphasized the distinction to be made between the legitimacy and the legality of transformative decisions that were consistent with the sentiments of the local population. Without denying that the occupying power could engage, as a matter of policy, in consultations with the local population, the experts, almost without exception, were of the view that such a process could not in any case make transformative policies lawful under IHL.

\section{c. Prolonged occupation}

A few experts then identified prolonged occupation as a situation allowing more transformations than short-term occupation. Some participants said that the longer an occupation lasted, the more policies and decisions aimed at 
effecting changes would be required, in order to meet the changing needs of the occupied territory. ${ }^{29}$

While they grasped the logic of this, many experts disputed the view that prolonged occupation could be sufficient grounds for effecting wholesale changes in the occupied territory. In particular, they pointed out the absence of any legal basis for such a position. The experts also emphasized once again the need to distinguish transformations authorized under IHL, in order to implement the overall obligation to maintain as normal a life as possible in occupied territory, from a transformative agenda aimed at remodelling the institutional and political landscape of the occupied territory. A broad consensus emerged among the experts that prolonged occupation could not be used as a legal basis for justifying transformations that would go beyond what was normally permitted under occupation law. Therefore, the experts agreed, an occupying power could not invoke the duration of its effective control over the occupied territory as justification for its failure to comply with the conservationist principle.

\section{d. Failed States}

The experts then discussed whether the occupation of a failed State altered the relevance and application of the conservationist principle. In the first place, it was noted that "failed State" was not a legal concept entailing new legal obligations under international law and IHL in particular. Therefore, most of the experts did not see any justification for departing from the principles and norms of occupation law in such circumstances. IHL was thus deemed as relevant for the occupation of a failed State as it was for more classical forms of occupation.

However, a majority of the experts also maintained that if a State deprived of basic administrative structures was under occupation, the occupying power would have a strong argument for introducing important changes, with a view to restoring local institutions. In fact, the experts explained, some provisions of the Fourth Geneva Convention implied the need for effective implementation of some form of cooperation between the ousted government and the occupying power. ${ }^{30}$ In a failed State, an occupying power would find some arguments under IHL for engaging in the restoration of local governmental institutions. In a failed State, where such cooperation was impossible, policies aimed at reintroducing governmental structures should be deemed lawful because they fell under the occupying power's overall obligation to maintain as normal a life as possible in occupied territory.

The debates then focused on limiting the changes that could be undertaken in an occupied failed State. The experts tried to define a "red line" beyond which decisions about the revival of local institutions would become unlawful for the purposes of IHL. Most of the participants took the view that this "red line" was the complete restructuring of the occupied territory's executive, legislative, judicial and administrative institutions as opposed to their restoration. While the latter would be legally permissible, since it would be in fulfilment of the obligation to restore and ensure public order and civil life in occupied territory, the former would still be at odds with the conservationist principle. Accordingly, even in failed States, the occupying power was not entitled under IHL to change the institutional structures of the occupied territory. For example, it was not permitted to turn a monarchy into a republic or a federal State into a unitary State.

One expert disputed this, arguing that, in certain specific circumstances, the occupying power could engage in the restructuring of the local institutions rather than be obliged to restore the former institutions. The expert illustrated

It should be noted that one expert stated that prolonged occupation was, by its nature, transformative occupation. For a more detailed discussion of prolonged occupation, see infra part D.

30 Articles $6 \$ 3,47,50$, and 56 of the Fourth Geneva Convention were mentioned in this respect; all of them presuppose some form of cooperation between the local authorities and the occupying power to implement the obligations therein. 
his point by saying that the occupant should not re-introduce an absolute monarchy in the occupied territory since human rights law would support the establishment of a participatory form of government where a totalitarian government had previously existed.

This was vigorously contested by some experts who insisted on the illegality under occupation law of such radical changes. One expert finally said that if a transformation of political institutions was, exceptionally, to take place, it should at least be regulated by jus ad bellum or jus post-bellum, and the legal basis for it should not be sought in jus in bello.

\section{e. Security Council resolutions}

A very strong consensus among the experts quickly emerged regarding the capacity of the occupying power to carry out transformative policies in occupied territory on the basis of Security Council resolutions. In the experts' view, insofar as occupation law did not authorize the occupying power to engage in institutional reforms in occupied territory, Security Council resolutions - by virtue of the combined application of Articles 25 and 103 of the UN Charter - would be the only legal basis for pursuing transformative objectives.

The experts then discussed whether the Security Council resolution allowing for transformative undertakings should be explicit or implicit.

These discussions divided those arguing that the resolution should be explicit from those favouring more flexibility in the interpretation of Security Council resolutions addressing the occupying power's policies in occupied territory. While agreeing that the Security Council would not be likely to entirely discard the application of occupation law, as Resolution 1483 on Iraq showed, ${ }^{31}$ the experts were not able to reach a consensus on whether derogation from the conservationist principle should be explicit. One expert asserted that this, even if it was of consequence for the applicability of IHL, was more an issue of public international law than of IHL purely.

The experts then discussed the limits of the authorization provided by Security Councils to transform occupied territory.

One expert asserted that, under lex lata, the Security Council had no legal constraints and could sanction any actions in occupied territory that it wished to, including those aimed at overhauling local institutions.

This liberal position was contested by some participants who pointed out that the limits to the Security Council's power were to be found in the UN Charter and in jus cogens norms. However, other experts countered that it would be difficult to identify jus cogens norms within the provisions of occupation law that related to the administration of occupied territory.

For another expert, humanitarian norms found in IHL, especially those enumerated in Article $6 \$ 3$ of the Fourth Geneva Convention, were of a jus cogens nature and thus would not be derogable. ${ }^{32}$ Drawing a distinction between such nonderogable 'humanitarian' norms and other 'administrative' norms, the expert said, would be useful for identifying limits to the Security Council's power to overturn IHL norms and authorize certain decisions and policies otherwise prohibited under occupation law. Consequently, the expert said, the Security

See, in particular, operative $\$ 5$ of the Resolution, which reads as follows: "[The Security Council] [c]alls upon all concerned to comply fully with their obligations under international law in particular the Geneva Conventions of 1949 and The Hague Regulations of 1907," S/RES/1483(2003).

32 Article $6 \$ 3$ of the Fourth Geneva Convention states: “In the case of occupied territory, the application of the present Convention shall cease one year after the general close of military operations; however, the Occupying Power shall be bound, for the duration of the occupation, to the extent that such Power exercises the functions of government in such territory, by the provisions of the following Articles of the present Convention: 1 to 12, 27, 29 to 34, 47, 49, 51, 52, 53, 59, 61 to 77, 143." 
Council could be entitled only to override administrative norms of occupation law. Thus, it would have the power to grant the occupant a great deal of room to manoeuvre in enforcing a transformative agenda that pursued an objective similar to one promoted by the UN: ensuring international peace and security.

\section{PROLONGED OCCUPATION}

While discussing the legal framework applicable to occupation, many of the experts had pointed out that the norms of occupation law, in particular Article 43 of the Hague Regulations and Article 64 of the Fourth Geneva Convention, had originally been designed to regulate short-term occupations. However, the participants agreed that IHL did not set any limits to the time span of an occupation. It was therefore recognized that nothing under IHL would prevent occupying powers from embarking on a long-term occupation and that occupation law would continue to provide the legal framework applicable in such circumstances.

The experts stressed the point that long-term occupation would nonetheless raise specific legal issues. In particular, they said, prolonged occupation could conflict with the conservationist principle at the heart of occupation law. Although none of the experts disputed the general relevance of occupation law to prolonged occupation, some of them suggested that the interpretation of certain of its provisions should be adjusted to those specific circumstances.

\section{Long-term occupation: A situation justifying more leeway} for the occupying power?

The experts agreed from the outset that prolonged occupation could affect the implementation of occupation law and that it called for special measures. In fact, the duration of the occupation was a factor that could lead to transformations and changes in the occupied territory that would normally not be necessary during short-term occupation. In this regard, a majority of the experts emphasized the need to interpret occupation law flexibly when an occupation persisted. It was almost a given that there would be a need for changes on a far greater scale during protracted occupation, simply because public policies would have to be adjusted in order to keep up with the passage of time. Some experts argued that a freeze on the natural development of an occupied territory would inevitably result in stagnation, which would ultimately be detrimental to the population of that territory.

In such special circumstances, the changing needs of the civilian population would become even more pressing. Thus, decisions related to the social, economic and sometimes political realms should not be indefinitely postponed and must be taken into account in order to maintain as normal a life as possible in the occupied territory. By way of illustration, one of the experts took two examples from the situation in the occupied Palestinian territory - improvements to the electricity network and the construction of highways - to show how prolonged occupation could not but oblige the occupant to intervene for the benefit of the occupied population when the passage of time and changed circumstances so demanded. ${ }^{33}$

The participants were unanimously of the view that the welfare of the local population played a key role and should - along with the preservation of the occupying power's security interests - be established as the main principle guiding the measures and policies undertaken by the occupying power in the administration of the occupied territory. According to some experts, the practical relevance of this guiding principle in prolonged occupation was twofold. As mentioned above, tending to the welfare of the population of the occupied territory implied taking positive actions to make sure that the society did not slide backwards but kept up with the times, as it were. On the other hand, the welfare of the local population was equally important in setting restraints on an occupying power's actions during longterm occupation.

33 The expert specified that the obligation to administer the occupied territory for the benefit of its local population was notably elaborated by the Supreme Court of Israel; see, for instance, HCJ 393/82, Jamiat Askan et al. v. IDF Commander of Judea and Samaria, 37(4) PD, at 791-807 or HCJ 351/80, Jerusalem District Electricity Co. Ltd v. Minister of Energy and Infrastructure et al., 35(2) PD at 690 
Regarding the latter point, the experts agreed that it was vital that the measures undertaken by the occupying power be aimed mainly to benefit the local population - while taking into account the security concerns of the occupying forces. Those measures should in any case not further the occupying State's own interests (for instance, using the assets of the occupied territory to benefit its own population or economy). As explained during the debates, the risk with prolonged occupation was that the occupying power might wish to turn the occupation into a situation it wanted to maintain indefinitely, given the advantages to it of doing so.

After a large majority of the experts had acknowledged that in prolonged occupation the changed circumstances of civil life required the occupying power to take measures for the welfare of the population of the occupied territory, the question arose as to the kinds of measure that would be compatible with the framework set by IHL.

Two experts made the point that it was necessary to distinguish between maintenance and development on the one hand, and "transformation" on the other. One of them said that maintenance, within the meaning of IHL, could - with the passage of time - include changes, investment and development as well. Therefore, prolonged occupation could necessitate transformation but without being "transformative," since its purpose was not to remodel the institutional landscape of the occupied territory. Rather, decisions and policies made by the occupying power would still be legal when taken with a view to ensuring that the occupied territory could keep in touch with the constant evolutions that characterize modern societies. The other expert focused on the distinction between maintenance and development. Maintenance - which he explained as the preservation of a situation - was what an occupying power was obliged to do in a short-term occupation. Development, on the other hand, could be justified over years - as in prolonged occupation - to the extent that conditions had changed in the society and required adjustments.

Another expert, however, cautioned against overemphasizing the importance of the welfare of the local population while determining whether a measure taken by the occupying power would be permissible under IHL. He referred to "borderline cases" where it would not always be easy to find out whether changes had been made for the benefit of the population or for the furtherance of the occupying power's own interests. The expert did not rule out the possibility that the concept of the welfare of the local population could be abused by the occupying power to justify actions that would go beyond the limits set by IHL in short-term occupation.

The experts then went on to discuss the relevance of the conservationist principle in prolonged occupations and the potential for it to conflict with the need to give the occupying power more room to manoeuvre in such situations. One expert, who did not dissent from the overall consensus that the welfare of the local population was an important consideration in the decision-making process, pointed out that establishing prolonged occupation as a general justification for the occupying power's deviation from lex lata would put at risk the principle of preserving the status quo ante, on which occupation law relied. He said that it would be better to accept occupation law as it stood - with its limited room for developing the occupied territory, as implied by the conservationist principle - while recognizing at the same time that there were exceptional circumstances in which transformations were required. He argued that prolonged occupation could qualify as such an exception, one that demanded development rather than maintenance.

In other words, the expert suggested, the conservationist principle - albeit remaining the cornerstone of occupation law - could occasionally be adjusted in situations of long-term occupation and would not prevent the occupying power from taking specific measures otherwise prohibited in short-term occupations, provided they were carried out to benefit the population of the occupied territory.

Two experts went further. They asserted that the importance of the conservationist principle, as well as its impact on occupation law, had decreased. In essence, they contended, the conservationist principle was losing ground. They noted that the four assumptions 
that justified the establishment of the conservationist principle ${ }^{34}$ were no longer valid. Therefore, in situations of prolonged occupation, the case for the conservationist principle had weakened significantly, which permitted a more interventionist approach by the occupying power.

Despite their differences of opinion about the relevance of the conservationist principle, the experts, almost without exception, agreed that there was no indication that IHL allowed a general disregard for occupation law merely because the occupying power had embarked upon a long-term occupation. It was also asserted that there was no indication that the States party to the four Geneva Conventions of 1949 interpreted the relevant provisions of IHL as granting the occupant a blank cheque in such situations. In fact, the experts asserted, the policies and decisions of the occupying power should still reflect respect for the principles contained in the Hague Regulations and the Fourth Geneva Convention, which remain flexible enough to accommodate most of the needs that arise during prolonged occupation and to ensure that the welfare of the population of the occupied territory would be taken into account.

Despite its importance for defining the obligations of the occupied power in prolonged occupation, some of the experts said, the term 'welfare of the population' was vague. They suggested referring to human rights law to flesh out the notion and to analyse how it impinged upon the occupying power's duties under occupation law. These experts referred in particular to the rights to health, education, housing and food, which, they claimed, were only vaguely alluded to or not dealt with at all in the Fourth Geneva Convention. Thus, it was suggested, human rights law could play an important role in substantiating and supplementing the meaning of the term 'welfare of the population.'

In sum, while most of the experts viewed prolonged occupation as a situation in which the occupant may be granted more powers for administering the occupied territory, the discussions also highlighted the need for identifying means to evaluate whether the occupying power's policies were effectively aimed at ensuring the welfare of the local population.

\section{How can it be ensured that the measures adopted}

by the occupying power preserve the well-being

of the local population and are lawful?

Many of the experts asserted that IHL, including occupation law, lacked effective mechanisms for its enforcement. Consequently, occupation law left it to the occupying power to determine whether the changes it sought to introduce during prolonged occupation were permissible and contributed to the welfare of the local population. Practice suggested that whatever criteria were applied, the occupying power usually concluded that the changes effected were lawful. The experts emphasized that this question deserved serious examination: Are the measures taken by an occupying power during prolonged occupation necessary for the purposes of IHL? They proposed three solutions.

\section{a. A litmus test}

One expert put forward a so-called litmus test, according to which the distinction between legitimate and illegitimate concern for the well-being of the local population would hinge on whether the occupying power showed similar concern for the welfare of its own population. Therefore, the lawfulness of the occupying power's decisions or legislation aimed at improving the situation of the local population should be measured against the existence of its equivalent in the territory of the occupying State. Should similar pieces of legislation not be in force in the occupant's own territory, the measures would be considered not to have been introduced effectively for the welfare of the occupied population and thus presumed to be unlawful for the purposes of occupation law.

According to the experts, the assumptions were these: firstly, occupation is necessarily of short duration; secondly, occupiers will always, while administering the occupied territory, preserve the well-being of the population; thirdly, the occupying power will not interfere in the relationship between the government of the occupied territory and its population; and fourthly, the existence of an atmosphere of laissez faire, according to which the government (and consequently the occupying power in situations of occupation) was expected to intervene very little in public affairs. 
The expert also specified that this litmus test worked only in a negative sense since it would help mainly to identify unlawful measures (i.e. those that had no equivalent in the occupying State).

However, some of the participants openly challenged the relevance of this litmus test. They pointed out that the existence of similar legislation in the occupying State did not mean that the measure - if introduced in the occupied territory - would necessarily contribute to the welfare of the local population. What was good for the occupying State's population would not necessarily be good for the local population as well.

One participant who criticized the test said that the occupant - in the exercise of its administrative powers - should take into account as far as possible the specific circumstances and standards in force in the occupied territory, irrespective of the fulfilment of the proposed litmus test. Even if parallel legislation in the occupying State were to exist, local traditions could prevent the occupying power from implementing a specific measure in the occupied territory. To illustrate this point, one expert said that legislation introduced by the occupant in the occupied territory, with a view to granting women the right to vote - which existed on the occupying power's territory - would not be permissible if at odds with local cultural or religious standards. ${ }^{35}$

The proposed test was also challenged on the grounds that it could not be considered a substitute for the relevant norms of occupation law, which remained the basis for assessing the lawfulness of a measure taken by the occupying power. Some of the experts said that the litmus test would not in any case relieve the occupying power of its duty to respect the limits - set out in Article $64 \$ 2$ of the Fourth Geneva Convention ${ }^{36}$ - on enacting new legislation. Consequently, even if a measure taken for the occupied territory had its equivalent in the occupying power's own territory, it would not be lawful under IHL if it was not deemed essential to enable the occupying forces to fulfil their obligations under IHL or to maintain orderly government in the territory.

Another expert also contested the validity of the test on the basis that the occupying power had no sovereign title over the occupied territory and could not legislate there as it did within its own territory. He added that the so-called litmus test could be too easily abused and subjected to bad-faith application for it to be established as a benchmark on the lawfulness under occupation law of measures taken by the occupying power.

\section{b. The involvement of the local population in the occupying}

power's decision-making processes

Some experts said that the longer an occupation lasted, the more the local population should be consulted on decisions about the administration of the occupied territory, except when the security of the occupying power was at stake. In fact, some experts said, the consent of the local population should be the only test used to analyse the intentions behind the occupant's measures. Such consent would be an important indicator in assessing whether a measure taken by the occupying power would effectively be in the best interests of the local population.

Thus, the experts took the view that long-term occupation required the occupying power to take into consideration the will of the local population by

35 However, some experts pointed out that the example provided was a clear demonstration of discrimination, which would violate certain norms of occupation law. Consequently, the occupying power would be under an obligation to rectify the situation and introduce changes aimed at abolishing the discrimination.

36 Article $64 \$ 2$ states that the occupying power may subject the local population to provisions that are essential for enabling the occupant to fulfil its obligations under IHL, for maintaining orderly government of the territory and for ensuring its own security. 
including it in the decision-making process. Nonetheless, they agreed that such involvement should not be of a general nature but should be limited to subjects not touching upon the security and military interests of the occupying forces.

Despite this consensus, the experts found it difficult to identify the most suitable means and methods for involving the local population in the decision-making process. To this end, one expert proposed the creation of a body faithfully representing the various components of the local population: this body would be entitled to collaborate with the occupant on implementing the measures taken. It would be given the task of channelling the will of the local population. The body or its members would act as the spokesperson, so to speak, of the occupied population, and as such would guarantee that the will of population was reflected as far as possible in the occupying power's decisions.

Another expert pointed out that such representation was not absent from IHL, since the Fourth Geneva Convention foresaw, in the context of internment camps, the setting up of internees' committees empowered to represent internees before the detaining authority. ${ }^{37}$ Thus, mutatis mutandis, a mechanism of similar nature could be imagined for a situation of occupation, to ensure that the population was represented before the occupying authority and that it had a role in making decisions concerning the administration of the occupied territory. ${ }^{38}$

Some experts, while recognizing the potential usefulness of such a committee of representatives, nonetheless expressed doubts about the relevance of mechanisms whose effectiveness and proper functioning would rely mainly on the occupying power's good faith and willingness to cooperate with the local population. One expert said that the most effective way to realize the local population's aspirations for involvement in the decision-making process would be to gradually transfer authority from the occupying power to the local government. In this way, the latter would be entitled to run the day-to-day administration of the occupied territory while the former would retain responsibility for security matters.

After acknowledging that the occupying power might resist the involvement of the local population, the experts explored other avenues to determine whether the occupying power's measures were aimed at ensuring the welfare of the local population, focusing in particular on the involvement of external actors.

\section{c. The need for external mechanisms of control}

There was broad agreement among the experts about the need for a supervisory mechanism to oversee the occupying power's decisions, in order to assess the extent to which they were for the benefit of the population and/or in conformity with the law. However, the experts disagreed about the actors best suited to carry out this task. ${ }^{39}$

First, some experts suggested the UN as a candidate. This was challenged by one participant, who declared that the UN lacked the required impartiality and neutrality for such a task, given the difficult relationships observed over time between the organization and occupying powers. Some participants rejected this contention, citing the recent occupation of Iraq by a coalition of States, which showed that the UN was able to cooperate with occupying powers and monitor, to a certain extent, some of their actions.

3 Article 102 of the Fourth Geneva Convention.

38 During the discussions, one expert made a link between the necessity of involving the local population in the decisionmaking process and the occupant's obligation to respect human rights law in occupied territory, in particular the right to selfdetermination. He argued that involving local people in the taking of decisions could be a means of achieving internal selfdetermination. Another expert distinguished between internal self-determination, realization of which becomes increasingly important over time, and external self-determination, which should not be implemented by the occupying power during occupation. Yet another expert disputed the relevance of the concept of self-determination, arguing that it had no place in the administration of the occupied territory and that it was more a jus ad bellum issue than a jus in bello one.

39 Only one expert challenged the need to have a discussion on the importance of having a monitoring mechanism. 
Another expert, without denying the political role the UN could play vis-à-vis long-term occupation, nonetheless wondered whether it could authoritatively apply IHL or evaluate with the required degree of precision the legality, under occupation law, of the decisions or policies introduced by the occupying power. He proposed the ICRC instead, a key organization capable of acting with the required impartiality and neutrality and possessing the necessary legal knowledge to evaluate whether the occupying power's actions were compatible with IHL. He said that it would be better to rely either on the ICRC or on the community of the High Contracting Parties to the Fourth Geneva Convention to scrutinize the actions or the inaction of the occupant in the exercise of its authority. However, some of the experts doubted that the ICRC would be the right organization to act as a monitoring mechanism, in particular because of its working procedures and lack of enforcement capability.

The debate on this issue concluded with a majority of the experts recognizing the importance of having a mechanism monitoring the decisions taken by the occupying power; the experts could not, however, agree about the nature of this mechanism or its working procedures.

\section{Article $6 \$ 3$ of the Fourth Geneva Convention and prolonged occupation}

While discussing the general legal framework applicable to long-term occupation, the experts briefly addressed the relevance and validity of Article $6 \$ 3$ of the Fourth Geneva Convention..$^{40}$

Some of the experts contested the relevance of this Article on the basis that it was out of touch with the tenor and practice of contemporary occupations. They said that it implied consensual cooperation between the occupying power and the ousted government, accompanied by the progressive transfer of power, which was not the case in most recent occupations.

Some experts also questioned the ongoing validity of Article $6 \$ 3$ under the law. They said that this provision had fallen into desuetude until its revival by the ICJ, in its Advisory Opinion on the legality of the construction of a wall in occupied Palestinian territory. Although the experts agreed that the ICJ's statement on this Article was incorrect for the purposes of IHL, ${ }^{41}$ they contended that - as a consequence - its validity could not be completely disregarded and its desuetude not yet established. ${ }^{42}$

However, a few experts warned against exaggerating the importance of the ICJ's statement. They pointed out first, that it was an advisory opinion, in which the ICJ had not provided further elaboration of the issue. Second, the experts said, as a matter of law, Article $6 \$ 3$ did not survive the advent of Article 3(b) of Protocol I of 8 June 1977 additional to the four Geneva Conventions (Additional Protocol I). This was clearly the case for States party to Additional Protocol I, and arguably for all other States if the paragraph was considered to be customary

40 Article $6 \$ 3$ of the Fourth Geneva Convention states: "In the case of occupied territory, the application of the present Convention shall cease one year after the general close of military operations; however, the Occupying Power shall be bound, for the duration of the occupation, to the extent that such Power exercises the functions of government in such territory, by the provisions of the following Articles of the present Convention: 1 to 12, 27, 29 to 34, 47, 49, 51, 52, 53, 59, 61 to 77, 143."

41 The advisory opinion refers incorrectly to the military operations "leading to the occupation" while Article $6 \$ 3$ is broader in scope, insofar as it states that "[i]n the case of occupied territory, the application of the present Convention shall cease one year after the general close of military operations."

42 ICJ, Advisory Opinion on the Legal Consequences of the Construction of a Wall in the Occupied Palestinian Territory, 9 July $2004, \S 125$ : “A distinction is also made in the Fourth Geneva Convention between provisions applying during military operations leading to occupation and those that remain applicable throughout the entire period of occupation. It thus states in Article 6:

'The present Convention shall apply from the outset of any conflict or occupation mentioned in Article 2.

In the territory of Parties to the conflict, the application of the present Convention shall cease on the general close of military operations.

In the case of occupied territory, the application of the present Convention shall cease one year after the general close of military operations; however, the Occupying Power shall be bound, for the duration of the occupation, to the extent that such Power exercises the functions of government in such territory, by the provisions of the following Articles of the present Convention: 1 to $12,27,29$ to $34,47,49,51,52,53,59,61$ to 77,143 .

Protected persons whose release, repatriation or re-establishment may take place after such dates shall meanwhile continue to benefit by the present Convention.'

Since the military operations leading to the occupation of the West Bank in 1967 ended a long time ago, only those Articles of the Fourth Geneva Convention referred to in Article 6, paragraph 3, remain applicable in that occupied territory." 
in nature. In this regard, a majority of the experts took the view that all the provisions of occupation law applied until the termination of an occupation and, consequently, that the rationale behind Article 3 of Additional Protocol I replaced the principle underlying Article $6 \$ 3$.

\section{PART TWO: THE RELEVANCE OF OCCUPATION LAW FOR UN ADMINISTRATION OF TERRITORY 43}

\section{A. THE DE JURE APPLICABILITY OF OCCUPATION LAW TO UN ADMINISTRATION}

1. Can occupation law ever apply de jure to UN administration of territory? The experts began their examination of the relevance of occupation law for UN administrations with a lively discussion of whether this body of law was even applicable to such situations. This preliminary question was triggered by the fact that occupation law had never been applied de jure to UN administration of territory. As one expert pointed out, the involvement of the UN in the administration of Irian Jaya (1962-63), Eastern Slavonia (UNTAES, 1996-1998), East Timor (UNTAET, 1999-2002) and Kosovo (UNMIK, since 1999) never entailed the de jure application of occupation law. Consequently, it was not irrelevant to wonder whether UN administration of territory could ever fulfil the legal criteria required to classify a situation as an occupation.

Two experts strongly supported the de jure inapplicability of occupation law to international administration of territory. They pointed out that the legal authority of the UN operation would negate by itself the possibility of the de jure application of occupation law. While stressing the fact that the source of authority for the international administration emanated from the Security Council's mandate, ${ }^{44}$ they also implied that an ad hoc legal regime would always be sought for governing the UN administration and, consequently, occupation law necessarily displaced. They also pointed out that the de jure applicability of occupation law was also denied by the incongruity between occupation law and the purpose of the UN administration: the political and institutional transformation of the territory concerned. The experts contended that the conjunction of these two elements made it exceedingly improbable that occupation law could apply de jure to UN administration of territory.

However, the other participants, almost without exception, disputed these arguments and proposed counter-arguments. As to the incompatibility of the international administration's purposes with occupation law, they pointed out that the objectives of foreign presence were not included in the well-recognized legal criteria on which the applicability of occupation law relied (Article 42 of the Hague Regulations). Moreover, one participant asserted that the transformative purpose of an occupation per se in no way justified the inapplicability of occupation law, regardless of whether effective control was exercised by a State or by the UN.

In fact, the recent occupation of Iraq showed that occupying powers did not deny their duties under occupation law simply because their motives differed from those traditionally associated with occupiers. One expert said that opposing the applicability of occupation law to UN operations, based on the alleged nature and objective of the operations, disregarded reality, introduced a jus ad bellum argument into a discussion about the applicability of jus in bello, and ignored the strict distinction between these two branches of public international law.

In addition, some experts pointed out that Security Council resolutions had, until now, never displaced IHL or occupation law explicitly. In their view, arguments to discard the de jure applicability of occupation law based on the legal authority granted to UN administration were irrelevant.

The topic was introduced by a presentation given by one expert. See infra Appendix 2 .

44 For these experts, the Security Council's mandate was both an authorization for the UN administration to deploy and the legal regime within which it would operate. 
Thus, the majority of the participants believed that occupation law could apply de jure to UN administrations. Some experts said that occupation law could become the legal framework of reference, especially when the UN operation contained an element of enforcement in its mandate and found itself having to run the entire territory in which it was deployed or parts of it.

Four possible scenarios were then devised. It was proposed that occupation law could apply de jure to UN administration of territory as a result of: 1) UN invasion of a territory, 2) UN intervention in a failed State, 3) the handover of territory by a coalition of States who had taken control of another State, or 4) the withdrawal of the host State's consent to UN presence on its territory.

2. Application of the three-pronged test to the $\mathrm{UN}$ administration of territory While discussing these different possibilities, the experts said that, in any case, the legal criteria inferred from Article 42 of the Hague Regulations should still be fulfilled and effective control also duly established in order to apply occupation law to the situation under scrutiny. The fact that it was the UN administering a territory would not alter the rules of the game. Thus, the criteria for triggering the de jure application of occupation law would be similar to those applicable to more classical forms of occupation; and the three-pronged test elaborated during the first meeting of experts should still be applied.

According to this three-pronged test, adjusted to the particular characteristics of UN administration of territory, such an administration would amount to occupation for the purposes of IHL when the following conditions are fulfilled: 1) the UN's presence on the territory of a State is not consented to, 2) the local government is rendered substantially or completely incapable of exerting its powers by virtue of the UN's presence, and 3) the UN is in a position to exercise authority in place of the local government.

The experts then dealt in more detail with the application of these three legal criteria.

Before addressing the notion of consent, the experts discussed the other two criteria: the necessity that the local government be rendered incapable of exerting its authority and the related ability of the UN organs to exert its powers.

One expert said that these criteria would often not be met since the UN would generally not have exclusive authority over the territory in question, as apparently required by IHL: most of the time, the UN administration would be intervening in support of the local government and therefore would only be sharing, with the local authorities, the exercise of power. This expert took the view that in order to apply occupation law de jure to UN administration, the UN would have to be a full-fledged administrator with an all-inclusive mandate (i.e. to take over administrative, executive, legislative and judiciary powers).

However, this position was contested by some experts, who argued that the criteria drawn from Article 42 of the Hague Regulations did not call for exclusive authority over the occupied territory, but only for overall or ultimate authority, which was deemed quite different. Occupation law did not discard the possibility of a power-sharing arrangement between the occupying power and the occupied authority; it even expressly foresaw it for certain areas, such as education or health-care services. Power sharing did not affect the ultimate authority of the UN administration and did not impinge upon its ability to take and enforce decisions in the occupied territory. ${ }^{45}$ Therefore, it was not an issue influencing the legal classification of the situation.

The experts then discussed whether the UN administration could be an occupying power when it took over only the civil administration of a territory, while the military component of the mission was handled by armed forces distinct from UN organs (for example, armed forces belonging to another international organization, such as NATO, or to a coalition of States who had invaded the territory before handing it over to the UN).

45 See report on the first meeting of experts. 
One expert argued that occupation law would apply only where the international administration received a significant amount of support from affiliated armed forces capable of overcoming local armed resistance. Otherwise, the international administration could not be involved in a belligerent occupation. Other participants responded by noting that a non-consensual international administration, as in the four scenarios proposed previously, would generally be supported by a strong military component and could not therefore be confused with a 'peaceful' occupation.

Many experts were of the view that the complexity of the situation and the multifaceted structure of the international operation would not be sufficient reason for excluding the application of occupation law. As one expert expressly stated, the division of tasks among partners, whose combination of force and actions resulted in effective control over a territory, should not render occupation law inapplicable to the UN administration of territory.

Some experts asserted that in such circumstances, all the partners involved in the international administration of the territory should be classified as occupying powers for the purposes of IHL, provided they performed functions for which respect for occupation law could be relevant. Insofar as the UN would assume roles similar to those ascribed to an occupying power under IHL, the UN would fall squarely within the purview of this functional approach and would be subject to occupation law.

The experts then returned to the criterion related to the absence of consent. The discussions revealed strong differences of opinion among the experts about the interpretation of the notion of consent, as well as about the role that that idea played in the legal classification of the situation.

At least one expert regarded consent as a major hurdle to the de jure applicability of occupation law to UN administration of territory. This expert argued that the UN would generally seek out the consent of the host State and would therefore evade classification as a "hostile" entity in the meaning of Article 42 of the Hague Regulations, which sets out the elements of occupation. Thus, in his view, fulfilment of the 'absence of consent' criteria would generally be missing.

In this regard, it was unanimously agreed that a UN administration present on a territory with the consent of the sovereign could not trigger the de jure application of occupation law. Only the non-consensual presence of a UN administration would spark the de jure application of occupation law, provided the other two legal criteria addressed previously were met.

Two scenarios that might lead to absence of consent to UN administration of territory were brought up. First, it was noted that a UN administration could be deployed in a territory without the consent of the legitimate government $a b$ initio, even if such consent was subsequently provided. Second, there was a possibility of the sovereign revoking its initial consent during the UN operation. Despite the differences between these situations, the participants agreed, both would result in the de jure application of occupation law at the pertinent time. ${ }^{46}$

The experts were sharply divided on the subject of Kosovo, which illustrated how difficult concrete and objective evaluation of the consent criterion could be. The divisions among the experts were particularly obvious with regard to the methods and means of interpreting the notion of consent, and with regard to the identity of the consenter.

In fact, the experts, almost without exception, rejected the view that the UN administration of Kosovo could be compared to an occupation for the purposes of IHL, mainly because of the consensual nature of the UN's presence. However, a few experts argued that the consent of Serbia to the presence of the NATO-led Kosovo Force/United Nations Interim Administration Mission in Kosovo on its territory was either only formal or void ab initio

However, one expert stated that consent once given was irrevocable and that even a formal withdrawal of consent would not turn a UN administration into an occupation, provided the operation still benefited from a clear Security Council resolution justifying its presence on the territory concerned. This was judged by the other experts as confusing jus ad bellum and jus in bello, as well as confusing the legal basis for the UN operation and the legal framework governing the UN administration's actions. 
under Article 52 of the 1969 Vienna Convention on the Law of Treaties, because that consent had been obtained through the illegal use of force. The debates that followed illustrated the complexity of determining whether consent is vitiated or extorted through illegal use or threat of the use of force.

One participant suggested that using the Vienna Convention to determine the validity of consent could be problematic and not useful in practice. He referred in particular to the instances in which UN operations, such as the United Nations Transitional Administration in East Timor, were made possible because of certain threats of the use of force. This expert said that one should not regard some forms of threatened force as necessarily invalidating an agreement given by a sovereign. In this regard, another expert stressed the necessity of distinguishing duress from warning and emphasized the importance of evaluating the legality of the threat or the use of force while interpreting the notion of consent.

Despite these difficulties, some experts asserted that IHL, occupation law in particular, did not constitute a self-contained regime and did not provide for any criteria for evaluating consent. Therefore, the experts said, the issue of consent should be interpreted in the light of current public international law, in particular by reference to the law of treaties; and a specific interpretation of the notion of consent for the purposes of occupation law should not be sought.

However, this position was contested by two experts who argued that the notion of consent had a different meaning for the purposes of IHL, which allowed for a distinct and more relaxed interpretation. One expert said that a distinction should be made between illegal consent for the purposes of treaty law and illegal consent for the purposes of IHL, so that, in effect, even coerced consent within the meaning of Article 52 of the Vienna Convention would be consent, barring application of occupation law. These two experts also argued that the identity of the consenter was irrelevant for the legal classification of the situation. They maintained that consent need not emanate from the legitimate sovereign, but could also be given by the authority actually having effective control over the territory in question. For instance, the experts said, the UN administration in East Timor was not an occupation because Indonesia (which was at the time the occupying power of that territory) had consented to the deployment of both the International Force for East Timor and the United Nations Transitional Administration in East Timor.

This view of the matter was rejected by some experts who said that it could lead to absurd situations. They argued that according to this view, all that was needed to make occupation law abruptly inapplicable would be for the occupying power to consent to the international administration of a territory over which it had previously exerted effective control. In this regard, one expert drew attention to the abuses that could result if this view was put into practice, particularly when the consent was given not to the UN, but to another State. This would allow the latter to evade its responsibilities under occupation law and thus deprive the local inhabitants of the essential protection afforded by IHL.

Eventually, the majority of the experts agreed that consent to the UN administration must be given by the legitimate sovereign - and not by any other entity exerting effective control over the territory concerned, in particular the occupier - in order to thwart the de jure applicability of occupation law.

\section{B. THE RELATIONSHIP BETWEEN OCCUPATION LAW AND THE SECURITY COUNCIL RESOLUTION ESTABLISHING THE INTERNATIONAL ADMINISTRATION}

While discussing the application of the legal criteria for occupation, the experts addressed the influence of the Security Council mandate on the interpretation of consent, as well as on the application of occupation law to UN administration.

1. The impact of the Security Council resolution on the notion of consent One expert said that all discussions about the role of consent in determining the applicability of occupation law to UN administrations were irrelevant, as the most important element of 
the legal equation remained the mandate as delimited in the Security Council resolution, when adopted under Chapter VII of the UN Charter. In fact, for this expert, the only legal basis for UN administration of a territory was not the consent of the concerned sovereign, but the Security Council resolution and the related mandate assigned to the UN. The expert argued that the particularities of UN administration reduced the importance of the notion of consent with regard to occupation, and concluded by saying that even when consent began to waver, the legal framework regulating the UN administration would remain unaltered for as long as the UN's presence was based on the Security Council mandate. ${ }^{47}$

Another expert similarly played down the importance of consent in the occupation equation when UN administration was involved. This expert said that the Security Council - by virtue of its powers under the UN Charter - would be entitled to overrule flawed or even extorted consent and thus turn a belligerent occupation into a pacific occupation not subject to occupation law. However, the Security Council's ability to overrule the absence of consent must be subject to two conditions: the resolution should be adopted under Charter VII of the Charter and the terms of the Security Council resolution overriding the lack of consent should be explicit. ${ }^{48}$

These positions were disputed. One expert doubted that the Security Council could unilaterally end an occupation, not by changing the facts on the ground, but by simply re-classifying a belligerent occupation as an international administration not subject to IHL. Others agreed that such a resolution would be at odds with the core idea that the applicability of IHL depended on the facts on the ground and not on legal classification. These experts, however, said that the Security Council would be legally entitled to re-classify a situation, provided that was explicitly stated in the pertinent resolution.

A majority of the experts then said that the notion of consent could not be completely eliminated from any discussion of occupation, as this criterion was still a prerequisite for and a central element in defining the scope of the UN administration's obligations under public international law, IHL in particular. Some experts also said that the fact that the presence of a UN administration in a territory was sanctioned by a Security Council resolution did not presuppose that the "host" State had given genuine and valid consent and that occupation law's applicability had necessarily been rejected. They drew attention to the fact that the existence of a Security Council resolution validating the UN administration would not exclude the relevance and application of occupation law, in particular because Security Council resolutions establishing a UN administration usually did not include a detailed description of the applicable legal regime.

\section{Supplementing Security Council resolutions with IHL}

Therefore, and with a view to providing UN administrations with a clear legal framework, the experts underscored the necessity of supplementing pertinent Security Council resolutions with additional rules taken from various relevant legal instruments. The experts were of the opinion that the general legal framework applicable to UN administration consisted of two layers: the Security Council resolution and other rules stemming from the relevant instruments of public international law. The latter - including norms of occupation law - were regarded as filling gaps in the former.

One participant put forward two options for helping to define the UN administration's legal framework and to establish the relationship between the Security Council mandate and IHL. The first option would be to start from the presumption that IHL applied to the UN operation and then examine the extent to which the Security Council mandate referred to occupation law. The second option - which was the expert's preference - would reverse the process by first analysing the Security Council resolution - in particular the tasks assigned to the UN administration - and then examining how the mandate conferred upon the

This expert asserted that the notion of consent would not affect the rules governing UN administration since these rules found their source in Security Council resolutions.

48 One expert rejected the necessity of including an explicit operational paragraph in the Security Council resolution aimed at "repairing" the consent. The expert argued that the criterion of absence of consent could even be discarded through an implicit interpretation of the terms of the resolution, provided the resolution contained some indication of the drafters' intentions. 
international administration could accommodate occupation law as a residual body of rules. Some experts took note of the proposal, while others said that the element that would trigger the application of the residual rules was still missing.

Another expert made a slightly different proposal, which he called a "default rule theory." The starting point of this theory was that a UN mandate pursuant to Chapter VII would always prevail over other instruments of international law by virtue of the powers bestowed on the Security Council by the UN Charter. However, a UN mandate would never be detailed enough to permit the precise identification of the rules that would concretely apply to the UN administration: hence, the necessity of determining the default legal regime to be added to the Security Council mandate. The expert said that in order to determine these default rules, one should revert to the legal criteria determining a situation of occupation, in particular the absence of consent. Should the UN administration be deployed with the consent of the host State, the default legal regime would be human rights law. Should the UN administration be deployed without the consent of the sovereign, occupation law would then become the default legal regime complementing the Security Council resolution setting out the UN mandate. ${ }^{49}$

All the participants agreed with this "default rule theory": they thought that it would considerably facilitate delineation of the rules governing UN administration of territory.

Without challenging the unanimity of opinion on the "default rule theory," two experts said that the theory had some weaknesses. They noted, in particular, that difficulties could arise if the Security Council resolution did not grant sufficient authority to the UN administration to take on responsibilities or functions that would be allocated to traditional occupying powers under IHL. Such a situation could lead to questions about the apparent incompatibility between the authority granted to the UN administration under its mandate and the notion of authority within the meaning of Article 42 of the Hague Regulations. Should the former not meet the threshold established by the latter, the applicability of occupation law as the default rule could come into question.

Thus, many experts took the view that occupation law would apply as the default rule, to the extent that the scope of authority exerted by the UN administration amounted to effective control for the purposes of IHL. In this regard, and despite the fact that the notion of effective control should be analysed in the light of the prevailing facts, the terms of the Security Council mandate could be helpful. Those terms could also point to IHL as the relevant legal framework, provided the functions assigned to the UN administration resembled those normally assumed by occupying powers in more classical forms of occupation. ${ }^{50}$

\section{Can the Security Council resolution override occupation law entirely?}

Having defined a general legal framework that could be applicable to UN administrations and having identified more clearly the body of law that could efficiently complement the Security Council mandate, the experts turned their attention to the impact of the Security Council mandate on the content of the default/residual rules.

As it had been agreed that IHL could be a body of law binding upon a UN administration, the question arose as to whether this corpus juris had been derogated from by the Security Council. On this question, the experts, by a wide margin, agreed that the Security Council still retained the legal ability to override occupation law, rendering some of its norms inapplicable to UN administration. However, there were differences of opinion on whether the resolution overruling occupation law should make this explicit.

In this connection, one expert pointed out that the question mainly related to the interpretation of the pertinent Security Council resolution. He said that a presumption existed that

9 That is, provided that the two other criteria of the 'effective control' test have also been met.

50 However, one expert recommended against putting too much emphasis on the details of the mandate in order to draw conclusions about the legal framework applicable to UN administration. This was because of the concept of "mission creep," according to which the goals of a UN mission could substantially change over time through practice on the ground. The expert argued that this use of the terms of the mandate for determining the rules governing a UN administration should always be supplemented by continuous analysis of the prevailing facts. 
the Security Council would respect international law, including occupation law. However, this presumption being rebuttable, the applicability of occupation law could be denied on the basis of an implicit reference in the resolution, provided the resolution contained some indication of the drafters' intention to set aside IHL rules.

Two experts disputed this, saying that the existence of a presumption that the Security Council would conform to IHL rules would, before the application of occupation law could be denied in part or in its entirety, logically require explicit wording to that effect in the resolution. These experts asserted that deviation from occupation law could not be inferred from the standard clause on "all necessary means," often contained in Chapter VII resolutions. In fact, this clause meant only that the Security Council would not hesitate to authorize the use of force when necessary. The other participants agreed that the reference to "all necessary means" in a Security Council resolution could not serve as a basis for denying the applicability of IHL to UN administration.

\section{THE DE FACTO APPLICATION OF OCCUPATION LAW TO UN ADMINISTRATION}

1. The de facto application of occupation law as the most likely scenario During the discussions about the de jure applicability of occupation law to UN administration of territory, some experts had said that this body of law would, generally, be referred to only on a de facto or mutatis mutandis basis. They explained that, given the linchpin of lack of consent and the likelihood that the UN would deploy its operations with the consent of the State affected, the most likely scenario by far was the use of occupation law where it was not legally required, but where its application by analogy could serve useful purposes. This would be the case notably when neither the Security Council resolution nor other bodies of law, such as human rights law, could provide a clear-cut answer to certain situations in which the UN administration found itself. The experts agreed that occupation law would often be able to offer useful and practical guidance to the UN on subjects such as maintenance of public order and safety or management of private and public property.

Some experts also pointed out that the past practice of UN administrations - in particular, the United Nations Transitional Administration in East Timor and the United Nations Interim Administration Mission in Kosovo - showed that occupation law was never applied de jure. This, combined with the UN's reluctance to be considered an occupying power (because of the pejorative connotation of the term), led some experts to state that occupation law would only apply de facto to UN administrations, and thus could be used in circumstances and conditions other than those in which it would normally apply.

In this regard, some participants contended that the mutatis mutandis argument was the only one that could justify the application of occupation law to UN administrations. In fact, they claimed, the customary nature of certain provisions of this body of law had not been established in relation to international administration of territory. These participants particularly disputed any suggestion that customary occupation law applicable to UN administration was identical to customary occupation law applicable to States, especially because of the scarcity of practice in that respect. They concluded that the application of customary occupation law should be limited to situations in which effective control was exercised by States and that this could not yet be extended to international organizations, such as the UN, operating with the consent of the sovereign. ${ }^{51}$ Therefore, they said, there was a gap in the law that could be filled only by de facto reference to and application by analogy of the relevant norms of occupation law.

However, this conclusion was challenged by some participants, who stressed that it would revive the question of whether IHL could apply de jure to the UN per se. These experts regarded the applicability of IHL to UN organs as something that had been settled, and since occupation law was an integral part of IHL, there would be no reason to suppose that it would not legally apply to the UN as such. They also pointed out that the fact that the UN operations in East Timor and Kosovo both applied occupation law de facto suggested the emergence of a UN practice in the area of occupation law, giving support to the argument that norms of customary occupation law that are binding upon international organizations do exist. 
2. Is human rights law always more appropriate than IHL for UN administration of territory?

Three other experts expressed their dissatisfaction with the issue of the de facto application of occupation law to UN administrations and challenged its relevance. They argued that the de facto application of occupation law to UN administration was simply irrelevant. First, they asserted, the de facto theory was at odds with the so-called "default rule theory" established through consensus in the previous working session. The experts said that the default theory would not allow room for the de facto application of occupation law, because the non-fulfilment of the criteria stemming from Article 42 of the Hague Regulations could result only in the application of human rights law as the default rule and would definitively rule out the application of occupation law.

These experts also justified their mistrust of the de facto argument by drawing attention to the potential incongruity of occupation law and international administration, in particular because the former generally presupposed a hostile relationship between the foreign administrator and the local government and population while the latter was often characterized by peaceful cooperation between them. Consequently, they argued, human rights law was better suited to UN administrations than IHL. As further illustration of the point, they pointed out that the NATO-led Kosovo Force operating in Kosovo had opted to comply - as a matter of policy - with a legal framework drawn from human rights law and not from occupation law, thus dismissing the relevance of the latter as a de facto source of reference in such situations.

While sympathizing with these arguments, other experts nonetheless maintained that, unfortunately, human rights law could not provide answers to all the questions raised by international administration and therefore was not necessarily more appropriate for UN administration than IHL, particularly occupation law. These experts stressed the need to adopt a pragmatic and flexible approach, so that the international administration would be able to resort to occupation law by analogy when circumstances so required. ${ }^{52}$ They argued that occupation law could be used either as a matter of policy or only as a source of inspiration for the policies devised and implemented by the international administration. ${ }^{53}$

In support of this analysis, two participants pointed out that occupation law represented the most relevant body of law - besides the Security Council mandate - for regulating actions and decisions taken by UN administrations, because the rules contained in the Hague Regulations and the Fourth Geneva Convention constituted a legal regime aimed precisely at regulating the running of a territory on which the foreign administrator had no sovereign title. They also pointed out that human rights law, by contrast, was created for other purposes and contained formulations that were more open-ended and thus not always suitable for UN administrations. The obvious similarities between situations of occupation and international administration inclined them to designate occupation law as the more effective and suitable body of law complementing the legal framework set out

52 The experts asserted that such an approach would permit norms of occupation law to be adjusted to the specific characteristics of international administration; it would focus on the most relevant norms of this body of law while setting aside those not matching the UN administration's ultimate objectives.

53 While discussing the characteristics of the de facto application of occupation law, the experts advocated two options. The first consisted of applying all or some of the conventional or customary rules of occupation law as a matter of policy, that is, without any legal obligation to do so. The experts said that this option seemed to have been used only by Australia in agreeing to follow occupation law in its operations as the lead State in INTERFET (East Timor) and as a participating State in UNITAF (Somalia), both of which were UN-mandated operations. However, neither UNTAET nor UNMIK agreed, as a matter of policy to apply this body of law to constrain their operations, notably because they wanted to avoid having to take into account potential conflicts between their "duties" under occupation law and the mandate of the Security Council. The second option was that the UN administration would use occupation law only as an inspiration for its policies in the administered territory. Unlike the first option, the second was actively used by UNMIK. Some experts noted that the practice of the UN in Kosovo and East Timor had indeed been to rely on ideas stemming from IHL, particularly occupation law, for certain aspects of its operation, but in a way that did not entail a decision to comply with the rules themselves. In this regard, the UN seemed to have expressed the need to use relevant provisions of IHL as useful guideposts for policy-making without insisting that the rules be followed de jure or de facto. The importance of extracting the rule from the constraints attached to the formal conditions of its applicability was highlighted. Consequently, some experts declared, the role that norms of occupation law could play in UN administration of territory was so important that it justified some disregard for occupation law's usual scope of application. Finally, it was stressed that the UN was already using occupation law as a suitable starting point for developing a normative framework to govern the actions and policies of its administration in Kosovo and that there was no reason to believe that this influence would not continue in similar situations (although the majority of the experts repeated that the Security Council resolution remained the most important legal basis for action). 
by the Security Council resolution. These facts justified the initial introduction of norms of occupation law into the UN administration's mandate in Kosovo, and their subsequent use by analogy.

\section{Other arguments for the de facto application of occupation law}

One expert then identified five other reasons for the de facto application of occupation law: 1) the military personnel forming the armed wing of the international administration are very familiar with the concepts dealt with in occupation law; 2) this framework already exists, which would facilitate its immediate application at the beginning of the international administration; 3) occupation law recognizes the limited resources of the military forces deployed abroad and calibrates the occupier's rights and duties accordingly; 4) occupation law sets limits and imposes restraints on the foreign administration, preventing it from introducing unreasonable changes in the administered territory and 5) occupation law takes into account the tensions between the foreign authority and the suspended sovereignty.

Some experts, persuaded by these reasons, agreed that those involved in elaborating the legal framework governing international administrations should be able to resort to occupation law, which was a very practical and useful tool for dealing with such a grey area of public international law. One of the experts pointed out that practitioners and military lawyers involved in international administration often said that they were never confronted by a legal problem to which they could not find an appropriate answer in occupation law. Consequently, even if occupation law was not deemed formally applicable to UN administrations, it still provided practical solutions to many problems confronted by UN administrations.

The experts stressed occupation law's usefulness in dealing with such specific issues as the maintenance of public order and civil life, the management of public and private property, the implementation of taxes, and the possibility of resorting to requisitions and other security measures while keeping in mind the welfare of the local population. That makes this body of law particularly relevant for international administration of territory. Therefore, the experts concluded, the relevance of occupation law should not be restricted to belligerent occupation but should be extended to pacific occupation and consensual UN administration of territory.

On the basis of these arguments, the experts, almost without exception, supported the de facto application of occupation law, if it worked within the specific circumstances surrounding the establishment and development of the international administration.

\section{Arguments against the de facto application of occupation law}

Despite the majority view on the usefulness of the de facto application of occupation law to UN administration of foreign territory, some participants remained sceptical. They presented six arguments against it.

First, one expert asserted that the protection offered to the civilian population by occupation law would, typically, be less than that provided by human rights law. As one of the objectives that international administrations usually set themselves was the improvement of the human rights situation in the administered territory, the expert regarded the de facto application of occupation law in lieu of human rights law as being misguided.

Another expert pointed out that there was a risk, owing to the leeway given to the occupying power, that some norms of occupation law could be abused and/or used to circumvent stricter norms stemming from human rights law. He cited administrative detention as an example.

The expert also expressed concern about the consequences of applying the de facto theory for UN accountability, a third argument against the de facto application of occupation law to UN administrations. He stressed the point that violations - of occupation law - that lay at the origin of UN policies could not be effectively challenged, because of a lack of established accountability mechanisms for controlling the actions and decisions of the UN 
administration or for offering the victims of violations a right to remedy and reparations. This expert said that such a situation had occurred in Kosovo and turned out to be detrimental to the victims' right to reparations as no forum was available.

Another expert said that de facto application could become very problematic if it resulted in a pick-and-choose approach to norms of occupation law. Should this be the case, some participants declared, the integrity and coherence of IHL would be in danger. They explained that in fact, the UN administration could abuse the situation and choose to apply by analogy only norms conferring rights upon the occupying power while discarding those imposing obligations upon the foreign administration. This would create a very unbalanced situation, at odds with the spirit and premises of occupation law.

A fifth reason for not applying occupation law de facto was provided by a participant who pointed out that the premises on which occupation law rested would often conflict with the ultimate objectives of the Security Council. This participant said that the conservationist principle at the heart of occupation would be a major obstacle in this respect, as the changes that the international administration would have to effect in order to fully implement the Security Council's mandate would often exceed those normally permitted under occupation law. This should militate against the application mutatis mutandis of occupation law to UN administrations.

Finally, one expert pointed out that the de facto application of occupation law could raise important problems vis-à-vis the legal basis of decisions taken by the international administration. This expert asserted that a rule applied de facto could not be invoked as a legal basis for actions or decisions taken by the international administration. He cited norms of occupation law pertaining to internment and said that there was a sharp difference between using such rules as inspiration for policies and using them as a legal basis for detaining people. Other experts concurred that the legal basis for action should be sought elsewhere, in particular in the Security Council resolution, thus justifying the theory according to which occupation law would only be a residual body of law complementing a Security Council resolution.

Some experts, taking note of the differences of opinion during the discussions, said that adopting too dogmatic a position for or against the de facto application of occupation law seemed ill-advised. They said that while good arguments existed on both sides, the usefulness of occupation law would be more likely to depend on: the mandate from the Security Council; the relationship between the UN administrators and the territorial sovereign, and that between the UN and the local population; the prevalence of the rule of law in the territory affected; and other matters of this kind.

The experts also said that it was probably in international administrations that the importance of the interaction between IHL and human rights law could be seen most clearly. One expert who made a distinction between "calm" and "troubled" international administration said that human rights law should be applied if the situation was calm in the administered territory, and occupation law invoked by analogy in case of troubled administration.

Two other experts, referring to the interaction between human rights law and occupation law, proposed that these bodies of law be applied separately and at different phases of the international administration. They argued that occupation law would be more suitable and prove more useful in the initial phases of the international administration; human rights law would gradually replace it once the international administration stabilized and took root. These experts eventually agreed that de facto application of occupation law should remain an option for the international administration and should not be dismissed outright. 


\section{THE INTERRELATIONSHIP BETWEEN \\ THE LAW OF OCCUPATION AND ECONOMIC, SOCIAL AND CULTURAL RIGHTS: THE EXAMPLES OF FOOD AND HEALTH \\ BACKGROUND DOCUMENT BY DR SYLVAIN VITÉ LEGAL ADVISER, ICRC}

\section{INTRODUCTION}

Even though the issue is still a source of controversy, ${ }^{2}$ today there is little question that international human rights law is applicable to situations covered by international humanitarian law, i.e. armed conflicts and military occupations. This position has since been confirmed by a wealth of international practice, particularly that of the International Court of Justice. ${ }^{3}$ It is therefore appropriate to go beyond that preliminary stage to examine the interrelationship between the rules of international humanitarian law and human rights in the areas that are common to both. In the words of the Court itself, there are three facets to that interrelationship: "some rights may be exclusively matters of international humanitarian law; others may be exclusively matters of human rights law; yet others may be matters of both these branches of international law." However, the Court has not specified which rules are characteristic of one or other category.

The aim of this paper is to define those rules by focusing on one of the branches of international humanitarian law, namely that which applies to military occupation. From the perspective of human rights, the focus is on economic, social and cultural rights. These correspond to a specific mode of operation that distinguishes them from civil and political rights. ${ }^{5}$ This paper will first review broadly the general principles of application of economic, social and cultural rights during a period of occupation (A). It will then go on to examine how the two legal regimes under review actually interact in one specific area: the living conditions of the population - particularly as regards food and health (B).

\section{A. THE GENERAL PRINCIPLES GOVERNING THE APPLICATION OF ECONOMIC, SOCIAL AND CULTURAL RIGHTS DURING A PERIOD OF OCCUPATION}

The application of economic, social and cultural rights is a subtle matter. It varies according to the circumstances of each individual case and is required to evolve over time. The nature of those rights is partly programmatic, in the sense that they set objectives that States are obliged to achieve in stages. Their full realization is therefore achieved progressively. However, this flexibility is not such that it deprives the International Covenant on Economic, Social and Cultural Rights (hereafter

The views expressed in this document reflect the author's opinions and not necessarily those of the ICRC.

2 M.J. Dennis, "Application of human rights treaties extraterritorially in times of armed conflict and military occupation," American Journal of International Law, Vol. 99, No. 1, 2005, pp. 119-141.

3 International Court of Justice: Legality of the Threat or Use of Nuclear Weapons, Advisory Opinion, 8 July 1996, General List No. 95, para. 25; Legal Consequences of the Construction of a Wall in the Occupied Palestinian Territory, Advisory Opinion, 9 July 2004, General List No. 131, para. 106; Armed Activities on the Territory of the Congo, Democratic Republic of the Congo v. Uganda, General List No. 116, 19 December 2005, para. 216. See also Permanent Court of Arbitration: Partial Award, Civilians Claim, Ethiopia's Claim 5, 17 December 2004, para. 26.

4 ICJ, Legal Consequences, para. 106; ICJ, Armed Activities, para. 216.

5 See, in particular, P. Alston, G. Quinn, "The nature and scope of States Parties' obligations under the International Covenant on Economic, Social and Cultural Rights," Human Rights Quarterly, Vol. 9, No. 3, May 1987, pp. 156-229; A. Eide, "Economic, social and cultural rights as human rights," in A. Eide, C. Krause, A. Rosas (eds) Economic, Social and Cultural Rights: A Textbook, 2nd ed., Kluwer, 2001, pp. 9-28. 
referred to as the Covenant) of all constraining power. The system of economic, social and cultural rights provides for some minimum obligations of immediate effect that States cannot avoid (1). In addition to the functioning of the structure of human rights, there are some principles of application that derive from the law of occupation (2).

\section{THE PROGRESSIVE REALIZATION OF ECONOMIC, SOCIAL AND CULTURAL RIGHTS}

Article 2, paragraph 1, of the Covenant stipulates that each State Party "undertakes to take steps (...) to the maximum of its available resources, with a view to achieving progressively the full realization of the rights recognized in the present Covenant" (emphasis added). The instrument recognizes that its rules are to be applied over time and that their application may go through different stages by virtue of the very nature of the prescribed obligations. ${ }^{6}$ This flexibility is particularly important during a period of occupation. When hostilities have just ceased, a large number of infrastructures have been destroyed by war and the country is very often still suffering from considerable instability, the occupying power is not in a position to meet all its obligations. First of all, it has to deal with urgent needs. Then, when it has had the opportunity to strengthen its control over the territory in question, the normative content of its obligations becomes more extensive.

That room for manoeuvre is, however, not without restrictions. The progressive realization of economic, social and cultural rights does not mean that States have a right to wait for the most favourable circumstances before meeting their obligations. Such an interpretation would deprive the Covenant of its normative content, as each State would be free to decide the extent of its undertakings. The jurisprudence of the United Nations Committee on Economic, Social and Cultural Rights (hereafter referred to as the Committee) shows that States must adhere to a basic normative threshold, whatever the circumstances.

\section{The obligations which are of immediate effect}

The Committee recalled that "while the Covenant provides for progressive realization and acknowledges the constraints due to the limits of available resources, it also imposes various obligations which are of immediate effect." It distinguished between two normative levels: (a) provisions establishing obligations which are of immediate effect; (b) provisions establishing obligations which are to be realized progressively. States bound by that instrument would then not be able to refer to its programmatic nature in order to delay its application as a whole. It is incumbent upon them to respect the rules requiring immediate application, i.e. the obligations which are "inherently self-executing." ${ }^{\text {D }}$ During periods of occupation, these rules form a normative circle that the authorities in place must take into account as soon as they have effective control of the territory.

Some of the obligations of immediate effect are referred to explicitly in the Covenant. Others need to be identified by means of interpretation. By virtue of Article 2, paragraph 1, the States Parties are "to take steps," that is, to adopt specific measures to promote the full application of that instrument whatever the nature of the obligations concerned. Adopting a passive attitude in that respect would therefore be contrary to their commitments. Although, in some cases, the realization of economic, social and cultural rights may take place over time, States are still obliged to take steps without delay to allow them to achieve the set objectives. ${ }^{9}$ As reminded by the Committee, "[s]uch steps should

6 UN Committee on Economic, Social and Cultural Rights, General Comment No. 3: The Nature of States Parties' Obligations (Art. 2, para. 1, of the Covenant), 14 December 1990, para. 9. See also The Maastricht Guidelines on Violations of Economic, Social and Cultural Rights, UN Doc. E/C.12/2000/13, 2 October 2000, No. 8.

7 General Comment No. 3, para. 1 (emphasis added). See also The Limburg Principles on the Implementation of the International Covenant on Economic, Social and Cultural Rights, UN Doc., E/C.12/2000/13, 2 October 2000, No. 8.

8 General Comment No. 3, para. 5: "Any suggestion that the provisions indicated are inherently non-self-executing would seem to be difficult to sustain" (emphasis added).

9 UN Committee on Economic, Social and Cultural Rights, General Comment No. 3, paras 2 and 9. See also P. Alston, G. Quinn, footnote 4 above, p. 166 
be deliberate, concrete and targeted as clearly as possible towards meeting the obligations recognized in the Covenant." ${ }^{10}$ During periods of occupation, the authorities in place may therefore not refer to the temporary nature of their presence on foreign territory in order to evade these obligations. In this regard, it is worth reminding ourselves that the Administration of the occupation forces in Iraq justified redrafting the labour code of that country by recalling that, as a State party to ILO Conventions 138 and 182, Iraq was obliged to "take affirmative steps towards eliminating child labor."11

\section{The core content of economic, social and cultural rights}

The Committee also recognized that, despite their inherent flexibility, each of the economic, social and cultural rights has an irreducible normative content. Even though the Covenant proves its flexibility by recognizing that some provisions may be implemented progressively, it considers that the States Parties nonetheless have "a minimum core obligation to ensure the satisfaction of, at the very least, minimum essential levels of each of the rights." ${ }^{12}$ Each of the Covenant's provisions thus has a basic normative content that must be guaranteed in all circumstances, irrespective of the country's economic condition, its political situation or its institutional structure. ${ }^{13}$ That applies both in periods of military occupation and in times of peace. This core establishes in a sense the starting point from which the States Parties can plan how to fulfil their obligations progressively. It thus sets a limit to the flexibility allowed by virtue of Article 2, paragraph 1 .

\section{THE PRINCIPLE OF CONTINUITY OF THE LEGAL SYSTEM IN THE LAW OF OCCUPATION}

The application of economic, social and cultural rights during periods of occupation must also take account of the laws governing that kind of situation. In its Advisory Opinion on the Legal Consequences of the Construction of a Wall in the Occupied Palestinian Territory (2004), the International Court of Justice had occasion to recall that Israel, as the Occupying Power, was obliged to uphold the provisions of the Covenant "in the exercise of the powers available to it on this basis." 14 Yet, the content and scope of those powers can only be determined with reference to the law of occupation. The occupant is only authorized to make use of the room for manoeuvre allowed with regard to economic, social and cultural rights within the limits set by occupation law.

In some respects, the application of the Covenant implies a long-term perspective and the existence of the sovereign power to effect far-reaching transformations of societies. For example, the realization of the right to work obliges States to work out development strategies that commit their national economies for a good number of years. ${ }^{15}$ By contrast, the law of occupation offers resistance to changes of that kind. Its aim is to maintain the institutional and legal structures pending a decision on the future status of the territory concerned. Article 43 of the Hague Regulations of 1907 stipulates that the occupant is obliged to "restore, and ensure, as far as possible, public order and safety, while respecting, unless absolutely prevented, the laws in force in the country" (emphasis added). This rule prescribing the continuity of the internal legal system thus sets an upper limit to the realization of economic, social and cultural rights. It prohibits structural reforms that would affect the long-term future of the occupied territory.

\footnotetext{
General Comment No. 3, para. 2.

1 Coalition Provisional Authority, Order No. 89, Amendments to the Labor Code - Law No. 71 of 1987, CPA/ORD/05 May 2004/89 (emphasis added)

12 General Comment No. 3, para. 10 (emphasis added). See also The Maastricht Guidelines, No. 9.

13 See, in particular, A. Chapman, S. Russell (eds), Core Obligations: Building a Framework for Economic, Social and Cultural Rights, Antwerp/Oxford, Intersentia, 2002, 351 pp.

4 ICJ, Legal Consequences, para. 112.

15 Art. 6, para. 2.
} 
This principle is, however, not rigid. As stipulated in Article 43 of the Hague Regulations, the Occupying Powers may depart from it if they are "absolutely prevented" from complying with it. Article 64 of the Fourth Geneva Convention, which takes up and clarifies the rule given in Article 43 of the Hague Regulations, adds that legal amendments can be made when they are "essential" to the realization of three objectives: (a) implementing international humanitarian law; (b) maintaining the orderly government of the territory; and (c) ensuring the security of the Occupying Power and the local administration. ${ }^{16}$ The obligation to respect human rights must be added to these three hypotheses. ${ }^{17}$

The question that then arises is how to reconcile the occupant's obligation to apply human rights - which may at times imply legal reforms - with the principle of the continuity of the internal legal system, which is at the heart of the law of occupation. ${ }^{18}$ The answer to that question calls for the greatest caution and gives an indication of the slippage that could result from adopting too lax a position on this matter. Under cover of fulfilling its international obligations, an occupant could carry out structural transformations in the occupied country without consulting the people concerned. That risk is even greater with regard to economic, social and cultural rights, as the rules stipulated in that area are sometimes imprecise and open to irregular interpretations.

\section{B. THE INTERRELATIONSHIP BETWEEN THE LAW OF OCCUPATION AND ECONOMIC, SOCIAL AND CULTURAL RIGHTS WITH REGARD TO FOOD AND HEALTH}

The risk mentioned above may nonetheless be reduced if a more nuanced approach is pursued. The response actually needs to be adapted in accordance with the rules envisaged. In many ways, the realization of economic, social and cultural rights does not imply reforms that are so radical that they run counter to the law of occupation. The normative balance between occupation law and economic, social and cultural rights cannot therefore be found by studying only the general principles governing the application of the latter in situations of occupation. It needs to be sought on a case-bycase basis by analysing specific rules. That is what will now be attempted - by taking one example, that of the living conditions of the civilian population, with particular regard to food and health.

The legal regime of occupation is mainly emergency law. Its aim is to respond to the immediate needs of civilians in the power of a foreign army. Without neglecting concerns that are linked to the survival of the population, the system of economic, social and cultural rights is geared to the long term. While it establishes obligations that must be fulfilled in all circumstances and thus overlaps with the law of occupation, it also provides for obligations to be realized progressively as the situation in the territory stabilizes. As far as food and health are concerned, it thus complements the minimum rules of occupation.

\section{THE LAW OF OCCUPATION}

The law of occupation contains several provisions that deal with the living conditions of civilians. Generally, it requires the occupant to take "all the measures in his power to restore, and ensure, as far as possible, public order and safety." ${ }^{19}$ More particularly, the Fourth Geneva Convention stipulates that "the Occupying Power has the duty of ensuring

16 Despite the heading of Article 64, which refers to "penal legislation," this applies to the entire domestic legal system. Jean Pictet emphasizes in that respect that "the reason for the Diplomatic Conference making express reference only to respect for penal law was that it had not been sufficiently observed during past conflicts; there is no reason to infer a contrario that the occupation authorities are not also bound to respect the civil law of the country, or even its constitution" (J. Pictet, (ed.) Geneva Convention IV relative to the protection of civilian persons in time of war: Commentary, Geneva, ICRC, 1958, p. 360). See E. Benvenisti, The International Law of Occupation, Princeton/Oxford, Princeton University Press, (2nd ed.), 2004, pp. 100 ff.

17 M. Sassòli, "Legislation and maintenance of public order and civil life by occupying powers," European Journal of International Law, Vol. 16, 2005, p. 676.

18 For a more detailed evaluation of the scope of these two provisions, see S. Vité, "Applicability of the international law of military occupation to the activities of international organizations," International Review of the Red Cross, Vol. 86, No. 853, March 2004, pp. 14 ff. (Full text in French only.)

19 Hague Regulations, Art. 43. 
the food and medical supplies of the population." ${ }^{20}$ Additional Protocol I extends the range of that provision by adding that that obligation also covers "the provision of clothing, bedding, means of shelter, other supplies essential to the survival of the civilian population of the occupied territory and objects necessary for religious worship." ${ }^{21}$ If the Occupying Power is not able to fulfil that obligation, it must draw on external support. It must agree to and facilitate relief work for people in distress. ${ }^{22}$ That obligation is unconditional..$^{23}$

With regard to health, the Occupying Power is also responsible for ensuring the proper functioning of medical establishments and hospitals, as well as medical services, and for guaranteeing health and public hygiene. In particular, it must take all measures necessary to combat contagious diseases and epidemics. ${ }^{24}$

Those rules relative to living conditions during periods of occupation are general and confer discretionary powers on the authorities responsible for enforcing them. While they set certain requirements in terms of food, health, clothing and housing, they do not give precise indications about the objectives that have to be achieved. The very concepts of "satisfactory conditions" or "supplies" can be understood in very different ways. Moreover, conceived as a short-term transitional legal regime, the law of occupation focuses primarily on the duty to assist people in difficulty. When occupation persists, that obligation may well cease to be in line with the needs of the civilian population. In that case, it then ceases to be solely a matter of guaranteeing its survival but, as stipulated in Article 43 of the Hague Regulations of 1907, of restoring and ensuring public order and safety. However, the rules of occupation are not of great use when the implications of that provision need to be understood more precisely.

Given these uncertainties, some clarification can be found in the complementary contribution made by the international law of human rights, in particular the right to adequate food and the right to health. ${ }^{25}$ That contribution is made, on the one hand, by the concretization of minimum rules applicable at all times (core) and, on the other, by the identification of rules that have to be enforced progressively as the occupied territory stabilizes.

\section{THE CORE OF THE RIGHT TO ADEQUATE FOOD AND THE RIGHT TO HEALTH}

From the perspective of human rights law, the right to an adequate standard of living implies that each person has access to the conditions necessary for his or her individual livelihood. According to the terms of the Covenant, that essential minimum includes, in particular, adequate food, clothing and housing as well as the continuous improvement of living conditions. ${ }^{26}$ The Covenant also recognizes "the right of everyone to the enjoyment of the highest attainable standard of physical and mental health." ${ }^{27}$ The definition of the core of each of those rights establishes their minimum applicable content under all circumstances and consequently clarifies the rules applicable during periods of occupation.

The right to adequate food - with all that it implies - includes as an essential requirement the "fundamental right of everyone to be free from hunger." ${ }^{28}$ That rule constitutes its core. The Committee on Economic, Social and Cultural Rights thus confirms that the States Parties

Fourth Geneva Convention, Art. 55, para. 1.

21 Additional Protocol I, Art. 69, para. 1.

22 Fourth Geneva Convention, Art. 59, para. 1. For further details, see Fourth Geneva Convention, Arts 30 and 59, ff. See also R. Kolb, "De l'assistance humanitaire : La Résolution sur l'assistance humanitaire adoptée par l'Institut de droit international lors de sa Session de Bruges en 2003," International Review of the Red Cross, Vol. 856, 2004, pp. $853 \mathrm{ff}$.

4 Fourth Geneva Convention, Art. 56, para. 1; Additional Protocol I, Art. 14, para. 1.

25 Universal Declaration of Human Rights, Art. 25, para. 1; International Covenant on Economic, Social and Cultural Rights, Art. 11; Convention on the Rights of the Child, Art. 27.

26 International Covenant on Economic, Social and Cultural Rights, Art. 11. See A. Eide, footnote 4 above, p. 133. For an example of the application of the law on an adequate standard of living in periods of occupation, see Report of the Special Committee to Investigate Israeli Practices Affecting the Human Rights of the Palestinian People and Other Arabs of the Occupied Territories, A/58/311, 22 August 2003, paras $44 \mathrm{ff}$.

27 International Covenant on Economic, Social and Cultural Rights, Art. 12.

28 Ibid., Art. 11, para. 2. 
have "a core obligation to take the necessary action to mitigate and alleviate hunger (...) even in times of natural or other disasters." ${ }^{29}$ More precisely, it adds that the core content of the right to adequate food is respected when two conditions are met: (a) "the availability of food in a quantity and quality sufficient to satisfy the dietary needs of individuals, free from adverse substances, and acceptable within a given culture"; and (b) "the accessibility of such food in ways that are sustainable and that do not interfere with the enjoyment of other human rights." ${ }^{30}$ The right to adequate food thus goes far beyond the simple matter of the quantity of food available. That food must also meet certain quality criteria. ${ }^{31}$

During periods of occupation, that obligation finds its concrete expression in the duty either to ensure that the territory is provided with essential supplies or to accept and facilitate the deployment of relief operations. Economic, social and cultural rights are thus at one with the approach of international humanitarian law in that they impose an obligation to act or, at least, to not create obstacles. The Committee on Economic, Social and Cultural Rights has pointed to that duality in recalling that the right to adequate food incorporates, on the one hand, the obligation to fulfil, i.e. "to facilitate and (...) to provide," and, on the other, that of not preventing "access to humanitarian food aid in internal conflicts or other emergency situations." 32

The core of the right to adequate food may be violated, for example, when the occupation forces destroy the civilian population's food stocks, when they affect the means of production, especially by placing mines in agricultural areas, by displacing farming or fishing communities, by paralyzing the transport network that allows supplies to be distributed or by blocking access to certain basic services (obligation to respect). ${ }^{33}$ The same applies when the Occupying Power fails to adopt the measures needed to prevent possible third parties from carrying out similar practices (obligation to protect). Finally, that fundamental obligation may require the occupant to adopt certain positive measures (obligation to fulfil). The occupant is, in particular, to set up an effective relief distribution system and to take account of the needs of the most vulnerable persons, particularly children, the elderly and the handicapped. ${ }^{34}$

With regard to health, the minimum normative content consists of elements from the areas of health care and preventive measures. It implies, for example, the obligations to guarantee access without discrimination to medical equipment, medicines and medical services, an adequate supply of safe drinking water and the possibility of obtaining essential medicines as defined by the World Health Organization. ${ }^{35}$ Non-compliance with those obligations cannot be justified "under any circumstances whatsoever." Consequently, these are obligations "which are non-derogable." ${ }^{36}$ In the words of the Committee on Economic, Social and Cultural Rights, other rules must also be considered "of comparable priority." ${ }^{37}$ Those rules include, in particular, the obligation to provide immunization against the major infec-

29 Committee on Economic, Social and Cultural Rights, General Comment No. 12, para. 6.

30 Ibid., para. 8. On this particular point, see R. Künneman, "The right to adequate food: Violations related to its minimum core content," in A. Chapman, S. Russell (eds), Core Obligations: Building a Framework for Economic, Social and Cultural Rights, Antwerp/Oxford, Intersentia, 2002, pp. 161-183.

31 On this point, see General Comment No. 12, para. 7.

32 Committee on Economic, Social and Cultural Rights, General Comment No. 12, paras 15 and 19. Following the invasion of Kuwait in August 1990, 22,000 people took refuge in the Philippine embassy. The Iraqi troops had prohibited supplying those people, thus violating the right to food, as was subsequently confirmed by the United Nations Special Rapporteur called to report on these events; see Report on the Situation of Human Rights in Kuwait under Iraqi Occupation, W. Kälin, Special Rapporteur, E/CN.4/1992/26, 16 January 1992, para. 222. In its Concluding Observations of 2001 addressed to Israel, the Committee had, for example, criticized the government for having turned back international missions to supply civilians living in the occupied territories, particularly those of the ICRC; Concluding Observations, Israel, E/C.12/1/Add.69, 31 August 2001, para. 13.

33 See, for example, Committee on Economic, Social and Cultural Rights, Concluding Observations, Israel, E/C.12/1/Add.90, 26 June 2003.

34 For greater detail, see R. Künneman, footnote 30 above, pp. $177 \mathrm{ff}$.

35 Committee on Economic, Social and Cultural Rights, General Comment No. 14 (2000), The Right to the Highest Attainable Standard of Health (Art. 12 of the International Covenant on Economic, Social and Cultural Rights), E/C.12/2000/4, 11 August 2000, para. 43. See also Report on the International Conference on Primary Health Care, Alma-Ata, 6-12 September 1978, Health for All Series, No. 1, WHO, Geneva, 1978, Chapter 3, para. 50. On this subject, see A. Chapman, "Core obligations related to the right to health," in A. Chapman, S. Russell (eds), Core Obligations: Building a Framework for Economic, Social and Cultural Rights, Antwerp/Oxford, Intersentia, 2002, pp. 185-215.

36 Committee on Economic, Social and Cultural Rights, General Comment No. 14, para. 47.

37 Ibid., para. 44. 
tious diseases, to take measures to prevent, treat and control epidemic and endemic diseases and to provide education and access to information concerning the main health problems..$^{38}$ Those rules also form part of the core right to health.

In the area of health, as in that of food, economic, social and cultural rights therefore tend to make explicit reference to matters that are merely touched on by the law of occupation. ${ }^{39}$

\section{PROGRESSIVE REALIZATION OF THE RIGHT TO ADEQUATE FOOD AND THE RIGHT TO HEALTH}

The contribution made by human rights is nonetheless not merely to provide normative clarification. Apart from those minimum obligations, other obligations call for progressive realization in terms of food and health. On this point, economic, social and cultural rights complement the law of occupation, which remains general when it comes to defining a longterm normative framework. That contribution is all the more helpful when the occupation stabilizes and tends to persist. While assuming that certain immediate measures are adopted to cover the essential content of that right, the Committee also calls for a long-term approach to achieve its full realization progressively. ${ }^{40}$ Once the emergency period is over, it is no longer sufficient for the occupant to distribute food to the civilian population. The system of human rights provides for civilians to have access to the resources and means that enable them to ensure their own livelihood. ${ }^{41}$ To that end, the occupant must establish "measures in regard to all aspects of the food system, including the production, processing, distribution, marketing and consumption of safe food, as well as parallel measures in the fields of health, education, employment and social security." ${ }^{\prime 2}$ In particular, that means that it is obliged to ensure the sustainable management of the natural resources used to produce food. ${ }^{43}$ Also with regard to health, human rights require the authorities to look to the future if the occupation persists. For example, these authorities need to devise a "public health strategy and plan of action." ${ }^{\text {"4 }}$

The reforms intended to ensure adequate living conditions in occupied territories must not, however, go beyond the restraint imposed by the law of occupation. The principle of the continuity of the legal system imposes certain limits in that respect that do not apply to measures adopted by a State on its own territory in peacetime. With regard to food, for example, it is appropriate to carry out a separate examination of the various obligations imposed on the States. Some Covenant prescriptions are admissible with regard to the law of occupation, such as that which consists of "improv[ing] methods of production, conservation and distribution of food by making full use of technical and scientific knowledge, and by disseminating knowledge of the principles of nutrition. ${ }^{345}$ Their implementation does not imply far-reaching changes to the legal and institutional structure of the country. By contrast, other prescriptions, such as those that imply "developing or reforming agrarian systems," risk being problematic in that respect. As far as health is concerned, the obligations provided for by the Covenant do not seem to contravene the principle of the continuity of the legal system. Without making far-reaching changes to the structure of a society, it is possible to guarantee, for example, "the prevention, treatment and control of epidemic, endemic, occupational and other diseases" or "the creation of conditions which would assure to all medical service and medical attention in the event of sickness." ${ }^{37}$

38 Ibid., para. 44.

39 N. Lubell suggests that human rights therefore constitute a lex specialis with regard to health; N. Lubell, "Challenges in applying human rights law to armed conflict," International Review of the Red Cross, Vol. 87, No. 860, December 2005, p. 751. See also H.J. Heintze, "On the relationship between human rights law protection and international humanitarian law," International Review of the Red Cross, Vol. 86, No. 856, December 2004, p. 795.

3 Ibid. On this point, human rights overlap with the law of occupation. See the Hague Regulations of 1907, Art. 55. That provision stipulates that the occupant may only manage property (including the natural resources) and agricultural estates belonging to the occupied State as "administrator and usufructuary." It must therefore "safeguard the capital of these properties."

45 Art. 11, para. 2 (a).

46 Ibid.

47 Convention, Art. 12, para. 2 
The examples of food and of health thus show that the occupant's obligations are not limited to the minimum defined by international humanitarian law. They must be viewed from a perspective which encompasses the complementary contribution made by human rights.

\section{CONCLUSION}

The legal regime of occupation has experienced far-reaching changes since its foundations were established by treaty in 1907 and in 1949. The interaction of international humanitarian law and human rights has resulted in that normative system being broadened and enriched. It has been broadened because human rights law sometimes institutes new types of protection compared with those under humanitarian law. It has been deepened when their content is sufficiently detailed to concretize certain provisions of the Hague Regulations or the Fourth Geneva Convention.

These developments have nonetheless not been uniform. They need to be analysed on a case-by-case basis, i.e. by studying each of the areas governed by those laws during periods of occupation. That analysis first implies a differentiated approach depending on whether economic, social and cultural rights or civilian and political rights are under scrutiny. Each of those two areas involves distinct principles of implementation. ${ }^{48}$ Moreover, even if the focus is solely on economic, social and cultural rights, differences remain.

As far as food or health is concerned, international humanitarian law and human rights largely overlap when the issue in question is meeting the immediate needs of the civilian population. Conversely, when the occupation persists and the situation stabilizes, economic, social and cultural rights prove to be vital to understanding better the scope of the obligations of the foreign Power. They give concrete form to the general obligation to ensure public order and civil life as in Article 43 of the Hague Regulations of 1907. Their relation to the law of occupation is one of complementarity.

The interrelationship between the two bodies of law during periods of occupation cannot therefore be constructed by resorting to one principle that can be applied systematically. It is the outcome of a process of adaptation dictated by the different legal contents of the rules studied. One specific category has been chosen here to illustrate that delicate search for balance. This work could be appropriately continued in the future by applying the analysis to other areas, such as housing, work and education. ${ }^{49}$

48 For a comparative analysis of the two areas during periods of occupation, see R. Kolb, S. Vité, La protection des populations civiles soumises au pouvoir d'une armée étrangère, Brussels, Bruylant, to be published in 2009.

49 See J.T. Horowitz, "The right to education in occupied territories: Making more room for human rights in occupation law," Yearbook of International Humanitarian Law, Vol. 7, 2004, pp. 233-277. 
Governments and international organizations as well as academic commentators have remarked upon the similarities and differences between occupation of territory by States and administration of territory by the United Nations. Although formal administration of territory by the United Nations has been limited to a small number of cases, the possibility of future revival of this practice warrants consideration of the relevance of the law of occupation (hereafter LO) to this phenomenon. This paper attempts to sketch out the major issues in an attempt to guide the experts in their discussion.

\section{THE PHENOMENON OF UN ADMINISTRATION OF TERRITORY}

The decision by States to permit an international organization to administer territory, either pending a determination of its final status or permanently, predates the United Nations, with early examples such as the Saarland from 1920 to 1935 and Danzig from 1919 to 1939. With the demise of plans for UN administration of Trieste and Jerusalem in the 1940s and 1950s, the only example of UN administration until recently was the seven-month operation in 1962-63 in Irian Jaya during the territory's handover from the Netherlands to Indonesia. UN administration since the end of the Cold War has its antecedents in second-generation UN peace-keeping. In these operations, notably in Cambodia and El Salvador, the UN took a major role in the implementation of peace agreements, including through significant (even plenary) authority over civil administration, elections, economic reconstruction, and refugee repatriation. The UN did not formally administer territory, but was rather invited to assist the existing government (even if the UN had certain authorities to overrule it).

The three examples of de jure UN administration, other than West Irian, remain Eastern Slavonia (UNTAES, 1996-1998), East Timor (UNTAET, 1999-2002), and UNMIK/KFOR (1999- present). Each of these operations was authorized by the Security Council under Chapter VII, although in each case the Council's position on the final status of the territory was different - transfer of territory in the case of UNTAES, a referendum that could lead to independence in the case of UNTAET, and complete uncertainty in the case of Kosovo despite recognition in the authorizing resolution of the territorial integrity of Yugoslavia (now Serbia). In each case, the operations were deployed only following the consent of the State (or, in the case of UNTAES, non-State group) with effective control of the territory, although the Kosovo case was less clear than the others. All three operations were "Blue Helmet/Beret" operations, subject to the authority of the Secretary-General, although the Kosovo operation entrusted overall maintenance of stability and security to a delegated force, NATO, which operates KFOR.

\section{APPLICATION OF THE LO DE JURETO UN ADMINISTRATION}

The Hague Regulation Article 42's core threshold for an occupation - "Territory is considered occupied when it is actually placed under the authority of the hostile army [and the] occupation extends only to the territory where such authority has been established and can be exercised" - has been generally understood by States, courts, and scholars as suggesting that occupation begins and lasts as long as three criteria are met: (1) foreign forces are physically present in the territory of a State 
without its consent; (2) the authorities of the latter State lack the capacity to exercise authority in the territory; and (3) the foreign forces have the capacity to exercise authority over the territory.

\section{A. THE QUESTION OF CONSENT}

\section{The majority position: Consent is inconsistent with occupation}

The touchstone of belligerent occupation as reflected in the three-part criteria above - the occupation addressed by the Hague Regulations and the Fourth Geneva Convention - is the lack of consent of the territorial sovereign to the presence of foreign forces. The recognition in the Fourth Geneva Convention of an occupation "even if [it] meets with no armed resistance" (e.g. the occupation of Czechoslovakia in 1938-39) does not mean that occupation can take place with the consent of the territorial sovereign. ${ }^{2}$

\section{Determining initial consent}

The United Nations has, as a matter of practice, obtained consent to all three recent operations. In the case of Eastern Slavonia, the Croatian Serbs agreed to the deployment of UNTAES in a 1995 agreement with the government of Croatia; in Kosovo, Serbia agreed to the deployment of UNMIK and KFOR as a condition for ending the 1999 war; and Indonesia consented to the deployment of both INTERFET and UNTAET. ${ }^{3}$ Cerone and others have argued that the consent of Serbia to KFOR/UNMIK was either only formal or void ab initio under Article 52 of the Vienna Convention on the Law of Treaties as a result of its procurement through the illegal use of force. ${ }^{4}$ The UN and its members have, however, taken a much more pragmatic interpretation and regarded Serbia's consent as genuine as a matter of fact, thereby precluding applicability de jure of the LO. Though the issue is not free of doubt, the latter seems the correct interpretation in light of (a) the Serb attitude in 1999, which was one of reluctant, but genuine, consent, and not the mere signature of the agreement allowing KFOR to deploy in Kosovo; (b) the generally narrow interpretation that States have given to Article 52; and (c) the distinction between illegal consent for purposes of treaty law and illegal consent for purposes of the LO so that, in effect, even illegally obtained consent is still consent that bars the application of the $\mathrm{LO}^{5}$

As a result, the LO would apply de jure at the beginning of an occupation only if, contrary to its practice to date, the UN administered a territory without the initial consent of the sovereign. Given the unwillingness of member States to entrust UN forces with the invasion of a State followed by its occupation, it would seem that two scenarios represent the most likely possibility for an such an initially unconsented UN administration: (a) administration of a State that lacks any government that might consent to the mission; or (b) administration of a State or part of it following the ouster of the government by a State or group of States, acting with or without Security Council approval.

The first of these scenarios is the Somalia possibility, where it is still possible to imagine in the future some sort of UN administration absent governmental consent - although it is likely the UN would seek the consent of others with effective power to ease the operation of the mission. It is worth considering whether such unstructured consent counts for purposes of displacing the LO.

The key dissenting position remains that of Michael Kelly, who argues that the Geneva Conventions also cover 'non-belligerent' very broadly defined, to include what he calls "pacific occupation" or "occupation by agreement." Michael J. Kelley, Restoring and Maintaining Order in Complex Peace Operations: The Search for a Legal Framework (1999), pp. 149-54, 162-67.

3 SC Res. 1037, preamb. para. 4 (UNTAES); SC Res. 1244, preamb. para. 9 (KFOR/UNMIK); SC Res. 1264, preamb. para. 10 (INTERFET); SC Res. 1272 preamb. para. 13 (UNTAET). Indeed, one might argue that, in the case of UNTAES, the consent of the Croatian Serbs was not necessary to displace the LO as Croatia, which had territorial sovereignty over Eastern Slavonia, had consented to the deployment.

4 John Cerone, "Minding the gap: Outlining KFOR accountability in post-conflict Kosovo," 12 EJIL 469 (2001).

5 This does not mean, however, that consent is the same as simple lack of resistance, which, as noted above, can still trigger an occupation, and one might argue that in fact the Serbs simply failed to resist rather than consented. 
The second scenario is the one proposed by some States and commentators for Afghanistan in 2001 or Iraq in 2003 but unacceptable to the United States and its allies. This scenario seems unlikely when it comes to an entire State, but one could imagine States handing over control of part of an occupied territory to the $\mathrm{UN}$, in which case the UN would be an occupier subject to the LO.

\section{The effect of decaying consent}

Although prior UN territorial administrations all proceeded only after the territorial State had consented to the deployment of the forces, the possibility of revocation of consent by interested parties remains a reality. Determining when such consent has been revoked, and the legal and policy consequences of it, has been a challenge for the UN and States since Nasser's revocation of consent to UNEF's deployment in May 1967. But such explicit revocation is, in fact, not the most likely prospect for the UN. Rather, the State that agreed to the operation can withhold cooperation in important ways or encourage those under its control to do so; moreover, dissident elements may also cease to consent as a practical matter to the work of the UN operation.

One legal interpretation of consent that the UN could adopt might be that consent, once given, is irrevocable, and that even formal withdrawal of consent will not turn a UN administration into an occupation. This view, however, has not been the position of the ICRC with respect to State occupation; rather, as noted, it has taken a more pragmatic view and determined that the presence or absence of consent is a matter of fact of the government's current position, not a legal determination based on its signature of an agreement in the past or the validity of that agreement.

Assuming that the presence or absence of consent is a matter of fact and not law, the question arises as to when revocation takes place. The UN's position in the context of peace-keeping operations under Chapter VI - which require the consent of the host State - has traditionally been that revocation needs to be manifest before such an operation would lack the authority to conduct coercive action against uncooperative parties. Thus, for instance, the lack of cooperation of the Khmer Rouge to most of UNTAC was not seen as a legal impediment to coercive action (although it became a political impediment to it). ${ }^{7}$ The standard for determining when lack of consent turns a UN administration into an occupation may not, however, be the same standard as that for determining when Chapter VI authority reaches it limits. Given the significant changes that result when a territory is occupied - i.e. the wide range of duties imposed on occupiers and the rights that come along with them - it would seem that the UN's presence would turn into an occupation only following the sort of revocation of consent that makes the UN truly a belligerent vis-à-vis the State.

\section{B. THE TERRITORIAL CONTROL TEST}

The final two tests for an occupation concern the authority and control of the foreign occupiers vis-à-vis the territorial sovereign. Applying these tests in the case of UN administration breaks down into two questions: (a) Can a UN mission be in a position to exercise governmental authority to the effective exclusion of the territorial sovereign? and (b) Does a UN mission in fact do so? The answer to both of these questions seems to be positive, based on the experience of the three UN administrations since the 1990s. The missions took full advantage of their broad mandates from the Security Council and were in a position to exercise that authority on the ground to the exclusion of Croatian Serb (for UNTAES), Serb (for KFOR/UNMIK) and Indonesian (for UNTAET) authorities. All the forces were

7 This issue matters much less in the context of Chapter VII operations, where consent is not legally required, even if it is typically obtained up front. 
predominantly composed of military contingents. ${ }^{8}$ And although they did not patrol every part of the territory, they appeared to meet the tests for exercise of authority.

This pattern does not, however, mean that all future UN administrations will satisfy the criteria of effective authority over territory. One could imagine that UN forces or civilians deploy in an area, without the consent of the sovereign, and end up administering aspects of the territory without having control over it. This might well have been the situation in parts of Bosnia during that conflict (although the question of consent was also ambiguous at that time). However, if the UN decides to delegate some authority to local officials through a type of vertical power-sharing arrangement, but still retains the ability to reverse their actions, it will remain in control of the territory and thus an occupier.

\section{GENERAL OBJECTIONS TO DE JURE APPLICATION OF THE LO}

Despite the possibility that a UN force might meet the three criteria defining an occupying power, arguments can be made that the LO cannot apply to these situations. One idea is that the legal authority for the force - a resolution of a UN political organ (typically the Security Council) $)^{9}$ - negates the possibility of de jure application of the LO. A second idea is the incongruity between the LO and the purpose (not merely the vehicle) of UN administration, namely the transformation of the political status of such territory. These seem to be the positions of the UN's legal staff. ${ }^{10}$ A third claim is that the composition of the force makes the LO de jure inapplicable. These factors may have played a role in the absence of the LO from the Secretary-General's 1999 directive on the observance of IHL by UN forces.

\section{The purpose of the mission}

The purpose of a UN operation clearly differs from that of the typical occupation (although perhaps not of the atypical ones, such as Iraq). However, it seems difficult to conclude that the difference between the purposes of the LO and of $\mathrm{UN}$ administration makes the former de jure inapplicable. Rather, under IHL, application depends on the objective relationship between the foreign power and the territorial sovereign vis-à-vis the pertinent territory. One should no more expect the LO to be inapplicable because the UN's purpose is to transform a territory than to expect the law to be inapplicable because a State's purpose is to transform the territory it occupies. Assuming the separability of IHL from jus ad bellum, such arguments hold little water. And the Iraq case shows that occupiers have not denied their duties under the LO simply because their motives might differ from that of more classic occupiers. ${ }^{1}$

\section{The legal authority for UN administration}

A more sweeping proposition is that the LO cannot apply because the authority for UN administration emanates from the Security Council. This position has two steps: (a) that the Council legally can displace IHL, including the LO; and (b) that the Council in fact has displaced the LO in UN administrations. The first step seems evident, although some scholars have insisted that the Council cannot override certain IHL norms, and others state that any such derogation must be very explicit. ${ }^{12}$ The only exception to this proposition is the very small number of rules that may constitute jus cogens (such as the ban on torture), which, frankly, the Council will not seek to displace. Assuming the Council

At its maximum strength, UNTAES had 5,000 troops and 450 police officers; recently, KFOR has had approximately 15,000 NATO troops, whereas UNMIK has had approximately 800 international civilian staff; and at its peak UNTAET had approximately 6,400 troops and 2,000 foreign civilians (1,200 of whom were police officers).

9 The West Irian operation was authorized by the General Assembly.

10 Daphna Shraga, "Military occupation and UN transitional administrations: The analogy and its limitations," in M. Kohen (ed.), Promoting Justice, Human Rights and Conflict Resolution Through International Law (2007), pp. 479, 495.

11 See S. Vité , "L’applicabilité du droit international de l'occupation militaire aux activités des organisations internationales," International Review of the Red Cross, Vol. 86, No. 853, March 2004, pp. 9-20.

12 Compare Steven Ratner, "Foreign occupation and international territorial administration: The challenges of convergence," 16 EJIL 695 (2005); Robert Kolb, "Occupation in Iraq since 2003 and the powers of the UN Security Council," International Review of the Red Cross, Vol. 90, No. 869, March 2008, pp. 29-50; Marco Sassoli, "Legislation and maintenance of public order and civil life by occupying powers," 16 EJIL 661 (2005). 
has this capacity, the question of whether it has in fact displaced the LO in the context of UN administration requires a close look at each resolution. Certainly, the Council has never displaced IHL or the LO explicitly, although neither has it stated that the UN mission must comply with the LO or any other part of IHL. (Rather, it has spoken of respect for human rights law.) In the absence of evidence either way, it is reasonable to assume that the Council has not sought to completely displace the LO where it might legally apply. ${ }^{13}$

The more realistic question is whether the Council might choose to displace some of the rules of the LO in the event of a bona fide occupation meeting the three criteria. While the detailed rules of the LO are discussed in Part IV below, it is important at this stage to consider the relationship between the operation's mandate from the Council and the LO. As an initial matter, just as the Council has the authority to displace all of the LO that is not jus cogens, it has the authority to displace some of the rules. At the same time, it is doubtful that the Council will specifically state that a rule of the LO does not apply. In this event, the task for the UN administration is to determine, based on a close reading of both its mandate and the LO, whether the two sources of law require inconsistent actions by the UN administration. If they do not, then the administration must comply with both (again, assuming the threshold of LO applicability is met). But if they clearly require inconsistent action - even if the Council does not say "notwithstanding the law of occupation" or something similar - then the UN administration must comply solely with its mandate under Article 103 of the Charter. ${ }^{14}$ To give the most obvious example, if the Council's mandate requires a fundamental restructuring of the territory's economy or election system, conduct which seems barred by the Hague and Geneva rules for occupiers, then those rules must give way. A different approach might be needed if the Council created a UN administration through a recommendation and not a decision, or if the UN administration were established by the General Assembly.

\section{The nature of the force and administration}

The Security Council could create an international administration by deploying UN personnel who report to the Secretary-General, by authorizing foreign personnel who remain under each State's authority, or, as was done with Kosovo, both. One sweeping argument against the applicability of the LO de jure is that it cannot apply to actions by UN forces, as opposed to States under UN mandate. This is part of a larger argument about the applicability of IHL to UN forces, about which countless commentary has appeared. The debate has become largely academic because the Secretary-General ordered all UN forces to comply with certain rules of IHL - although, as noted, not specifically the LO - and because troop contributors do not appear to be arguing that their forces are not bound by IHL simply because they are part of a UN force. This might suggest that they would similarly not reject the possibility of de jure application of the LO when their troops contribute to a UN administration of territory. On the other hand, States' views on whether their troops have duties under the LO when they participate as blue helmets in the UN administration of territory do not appear to be explicitly stated. ${ }^{15}$

For an opposing view, see Vité, supra, p. 25.

I thus think the tests demanded by Kolb and Sassoli, supra, for displacement of IHL are too strict.

15 With respect to UN-mandated forces, which are not within the scope of the 1999 memorandum, the argument that the LO could not apply to them simply because of the UN mandate seems weak. Although Australia did reject the applicability de jure of the LO to INTERFET in East Timor, the rejection was due to the consent of Indonesia, not the authorizing resolution of the Security Council. Michael J. Kelly, Timothy L.H. McCormack, Paul Muggleton, and Bruce M. Oswald, "Legal aspects of Australia’s involvement in the International Force for East Timor," International Review of the Red Cross, Vol. 83, No. 841, March 2001, pp. 101-139. 


\section{DE FACTO APPLICATION OF THE LO TO UN ADMINISTRATION OF TERRITORIES}

Given the linchpin of lack of consent to occupation and the likelihood that the UN will continue to deploy such missions only with the consent of the State affected, the far more likely scenario is use of the LO where it is not required legally, in two senses: (a) the application as a matter of policy by the UN of all or some of the conventional or customary rules of the LO, without a legal obligation to do so; and (b) the use of the LO as inspiration for policy without actual adherence to its rules.

De facto application of the LO to UN administration has both advantages and disadvantages. On the positive side, (1) the LO offers clear minimal protections for the civilian population that will not typically be mentioned specifically in the UN mandate; (2) the LO offers ideas for UN administrators on important areas of the administration; (3) the LO may address matters that human rights law does not address, e.g. use of public and private property. On the negative side, (1) the protections offered to the civilian population by the LO are typically lower than those provided by human rights law; (2) the LO may prescribe policies that conflict with the mandate provided by the UN; (3) the LO assumes a position of mistrust and confrontation between the occupier and the population, suggesting an ill fit for an operation deployed under very different circumstances and for very different reasons; and (4) a pick-and-choose approach to the LO may undermine its coherence and suggest that certain aspects are more important than others.

A doctrinaire position in favor of or against the de facto application of the LO seems ill-advised. Both positions make good points but the utility of the LO will really depend upon the mandate from the Security Council, the relationship between the UN administrators and the territorial sovereign as well as the population, the state of the rule of law in the territory affected, and other factors. Indeed, when we turn to the practice of international territorial administrators, de facto application has proved an attractive policy.

The first option seems to have been used only by Australia in agreeing to follow the LO in its operations as the lead State in INTERFET (East Timor) and as a participating State in UNITAF (Somalia), both of which were UN-mandated operations. ${ }^{16}$ Of UNTAET, UNMIK and KFOR, none seems to have agreed to apply the LO as a matter of policy to constrain its operations. The Secretary-General's 1999 Memorandum does not explicitly require such adherence (although it is not meant to be an exhaustive listing), and the States contributing to these forces have not seen any advantages to voluntary compliance with the LO. The UN and participating States appear to have considered their duties as flowing exclusively from the Security Council and have not voluntarily sought to apply IHL, although it has been noted that IHL provides important rights to the occupier (e.g. concerning use of force) that should be relied upon de facto. ${ }^{17}$ This strategy has the advantage of enabling the UN to avoid considering potential conflicts between the duties under the LO and the mandate of the Security Council. Such a stance does not mean that the UN force is not, in fact, complying with the LO. It may indeed comply with certain aspects of the LO (e.g. humane treatment of detainees), but not because those rules are part of the LO.

The second option, however, has been actively used by UN missions as well as KFOR. The practice of the UN in Kosovo and East Timor, as well as of KFOR in Kosovo, has been to rely on ideas from IHL regarding aspects of their operation but in a way that does not entail a decision to comply with the rules themselves. This appears to be the case, for instance, with KFOR's detention policies. And the ICRC has made representations to these governing authorities to point out relevant provisions of IHL as useful guideposts for policy without insisting that the rules be followed de jure or even de facto. As Oswald notes, in this sense the law "serves as an appropriate starting point for developing a normative framework," ${ }^{\prime 8}$ although the mandate of the mission from the Security Council is the most important starting point.

16 Shraga, supra, p. 497.

17 See Martin Zwanenburg, "Pieces of the puzzle: Peace operations, occupation and the use of force," 45 Revue de Droit Militaire et de Droit la Guerre, pp. 239-244 (2006)

18 Bruce Oswald, "The law on military occupation: Answering the Challenges of Detention during Contemporary Peace Operations?" 8 Melbourne Journal of International Law, pp. 311-320 (2007) 
In these situations, IHL is one of several sources of law, along with not only the Council's resolution, but international human rights law and domestic law. Indeed, in most situations of international territorial administration, human rights law, rather than international humanitarian law, should be the default rule for the UN to apply (subject to the Council's resolution). A difficult question arises when a mission may apply a rule of IHL more restrictive than one in human rights law. I have suggested that this should take place when the mission faces serious security threats, ${ }^{19}$ but some might argue that IHL should never displace human rights law until it applies de jure.

\section{THE LO RULES MOST IMPLICATED IN UN ADMINISTRATIONS}

Whether the UN complies with the LO de jure or de facto, or simply uses it as a source of inspiration, it is important to consider what rules are most pertinent to its operations. Some of the rules of the LO seem irrelevant to UN administration, as the UN lacks the ability to violate, or interest in violating, them, e.g. the ban on settlement of population (Article 49 of the Fourth Geneva Convention), the ban on forced conscription (Article 51 of the Fourth Geneva Convention), protection of hospitals and medical personnel (Articles 18-22 of the Fourth Geneva Convention), the requirement to allow humanitarian consignments into the territory (Articles 23 and 59 of the Fourth Geneva Convention), or collective punishment (Hague Regulation 50). But others are as relevant to State occupation as to UN administration - whether or not the UN must comply, chooses to comply, or uses them as an inspiration for policy.

\section{A. PROVISIONS ON OVERALL LAW AND ORDER}

Hague Regulation 43, as supplemented by Article 64 of the Fourth Geneva Convention, provides the basic starting point requiring the occupier to restore, and then maintain, law and order over the territory, mandate to amend local laws if (and only if) necessary to perform this function. ${ }^{20}$ The presumption of maintaining local laws to the extent possible is useful to UN administrators. The Security Council did not specifically include such a provision in the resolutions authorizing the three transitional administrations, and early regulations of both UNMIK and UNTAET legislated such presumptions for those territories. At the same time, both of these core rules are phrased at such a high degree of generality that they provide only basic guidance as to which local laws should be superseded by the UN administrators.

Other regulations related to law and order may be more pertinent. Article 51 of the Fourth Geneva Convention gives the occupier rights to compel limited amounts of work, subject to various conditions including employment subject to local law. This authority may be useful in the event of natural disasters in UN-administered territory. And Article 55's obligation to ensure food and medical needs of the population, as well as Article 56's duty to maintain hospitals, are important, as they can ensure that the UN operation does not neglect these basic needs.

\section{B. PROVISIONS ON THE FUNCTIONING OF THE CIVIL ADMINISTRATION}

The LO generally requires the occupying power to make little or no change to the basic civil administration of the territory, subject again to the rules in Hague Regulation 43 and Article 64 of the Fourth Geneva Convention. The most specific provision in this regard is the ban, in Article 54 of the Fourth Geneva Convention, on altering the status of public officials for refusal to act based on their conscience (paragraph 1), without prejudice to the occupier's longstanding right to remove them if it so chooses (paragraph 2). This provision - whose exception swallows up much of the basic rule - is relatively specific, at least compared to the two rules on law and order noted above. Article 54's second paragraph may prove a useful tool to complement and implement the mandate from the Security Council 
when local officials stand in the way - although its invocation by UN officials would perhaps arouse even more hostility than an argument that the power to remove officials is inherent in the Security Council's mandate. In addition, Hague Regulation 55 on use of public buildings would require the UN to use these only as an administrator and keep them in good condition.

\section{PROVISIONS ON INTERNMENT}

UN administrations are likely to find themselves in situations where internment of individuals is an appealing option for addressing security threats to the mission. KFOR, INTERFET, and UNTAET all encountered this need. The LO offers basic provisions in Articles 5 and 78 of the Fourth Geneva Convention (as well as in Articles 41-46 regarding aliens). At the same time, human rights law would seem to require more extensive procedural protection, and some human rights advocates have suggested that human rights law would ban preventive detention entirely. Article 78 would limit UN detentions to "imperative reasons of security," require a "regular procedure," with a right of appeal, and require regular review, preferably every six months. Article 5's denial of communication to spies, saboteurs, or people "under definite suspicion of activity hostile to" the occupier (presumably a smaller class of people than those who can be detained under Article 78) sound severe, but make sense from the point of view of protecting the mission and the population of the territory from clearly dangerous elements. The very detailed rules on internment in Part III, Section IV of the Fourth Geneva Convention (Articles 79-141) provide an important baseline of protection during confinement, although some of the articles, notably those concerning the role of protecting powers, are irrelevant to the UN administration of territory. These rules would be supplemented by those in Article 75 of Additional Protocol I.

\section{PROVISIONS ON PENAL MATTERS}

Articles 64-77 of the Fourth Geneva Convention provide detailed provisions on the arrest and punishment of individuals during an occupation. Security Council mandates for UN administrations have not addressed these questions, and so the LO becomes an important source of legal obligation or policy. These include the presumptive continuation in force of criminal law (Article 64), the use of regular or military courts to try suspects (Articles 64 and 66),reduction from punishment of time served (Article 69), a regular trial with basic due process (Articles 71-73), and conditions of detention (Article 76). Additional protections are found in Article 75(4)-(7) of Additional Protocol I. UN administrations should regard these provisions as a minimum set of procedural safeguards, because human rights law, which the UN has also applied, will typically contain greater protection.

\section{E. PROVISIONS ON FINANCIAL AND PROPERTY MATTERS}

The Hague Regulations and the Geneva Conventions also contain provisions on respecting private property and on fiscal matters, such as the tax system and currency. Like the rules on detention and penal matters, these are not likely to be specifically considered by the Security Council, making the IHL rules quite relevant, either de jure or de facto. Hague Regulation 48 states that any tax collection by the occupier should "as far as is possible" adhere to existing taxation rules. Article 53 of the Fourth Geneva Convention limits seizure of governmental property to certain categories, although it is unclear whether a UN administration will need to do this, as it will be funded by the UN. As for private property, Hague and Geneva law put very strict limits on its seizure and destruction: Hague Article 46 contains an outright ban on confiscation and Article 53 of the Fourth Geneva Convention limits destruction to that "absolutely necessary by private military operations." Hague Article 52 and Article 55 of the Fourth Geneva Convention restrict, but do not prohibit, the occupier's ability to demand requisitions from the population, requiring payment in cash for them. This might be of some assistance if, for some reason, $\mathrm{UN}$ forces or administrators are in need of material that cannot be supplied by the UN itself. 


\section{QUESTION OF INSTITUTIONAL OVERSIGHT AND ACCOUNTABILITY}

One final question is the role of international institutions in ensuring that civilians are properly protected during UN administrations. One can imagine a number of institutions playing a role, not always in coordination. The ICRC, with its expertise in IHL, can provide ideas for compliance with the LO, and indeed gave advice to INTERFET in setting up its detention unit. However, human rights institutions within the mission or elsewhere in the UN system might argue for greater protection and demand changes if they are not met. The ombudsman within UNMIK played this role in Kosovo, although the Office of the United Nations High Commissioner for Refugees or even the Human Rights Council could be active here as well. This competing institutional oversight makes it imperative for the mission to decide how it will allocate the application of human rights law vs humanitarian law to a particular mission.

\section{CONCLUSION}

The foregoing suggests that the UN faces two distinct tasks in determining the relevance of the LO to its administration of territory - whether to apply the law de jure and, whether or not it does so, how to place the LO within the other legal frameworks that will govern its mission - notably the mandate from the Security Council, human rights law, and local law. The UN's flexibility in these matters will be more limited if it determines that the LO applies de jure. Such a determination would seem possible only if (a) the UN and it members agree on the possibility that the LO can apply as a general matter to UN forces or UN-mandated forces; (b) the mission in fact operates ( $a b$ initio or later) without the consent of the territorial State; and (c) the mission has the sort of effective control over the territory required for an occupation. The central factor will be the most complex to determine, but to date, States have not been willing to find the requisite absence of consent, and this seems like the pattern that will continue. If the LO does apply de jure, then the UN will be able to act inconsistently with it but only if the Council intends for it to do so in its mandate.

In the absence of de jure application, the UN's options for applying the LO are wide-ranging and will require a case-by-case examination of the mandate and of the particular rules in the LO, human rights law, and local law that govern the issue at hand. IHL may offer ideas, but so will human rights law, and the latter should be the basic rule. Determining when an IHL rule less protective of civilians ought to displace a rule from human rights law will remain a difficult question.

Finally, some practitioners have suggested the idea of a lex specialis to apply to UN administration of territory, perhaps along the lines of the Secretary-General's 1999 Memorandum. Certainly the complexity of the questions discussed above suggests that clarity is needed in terms of the triggers for and scope of both de jure application and de facto application. It is worth asking, however, given the vastly different possibilities for UN administration, whether such a lex specialis is possible or whether we can at best agree on some very broad principles to govern the UN during the administration of territory. Even the latter would be a significant accomplishment. 


\section{AGENDA AND GUIDING QUESTIONS AIMED AT FRAMING THE DISCUSSIONS}

\section{DAY ONE}

\section{DELIMITING THE RIGHTS AND DUTIES OF AN OCCUPYING POWER}

Working session 1: Article 43 of the Hague Regulations of 1907 (abbreviated as THR for the rest of this section) and Article 64 of the Fourth Geneva Convention (abbreviated as GCIV for the rest of this section) as key provisions for assessing the scope of the occupier's rights and duties

What is the exact scope of the occupier's authority under Article 43 of THR and Article 64 of GCIV? Are these articles permissive or restrictive by nature?

What is the meaning and scope of the obligation to ensure public order and safety, which is incumbent upon the occupying power?

To what extent can the occupying power legislate in occupied territory? What is the meaning of the expression "unless absolutely prevented" contained in Article 43 of THR? How does Article 43 of THR interact with Article $64 \$ 2$ of GCIV?

May the occupier legislate to enhance "civil life" in occupied territory? May the occupier legislate to implement international law in occupied territory, in particular human rights law? May the occupier undertake legislative measures aimed at altering the political and institutional structure of occupied territory? May the occupier legislate in order to further the right to self-determination in occupied territory?

How does Article 43 of THR interact with other norms of occupation law? Can it supersede these norms in certain cases?

Do Article 43 of THR and Article 64 of GCIV entitle the occupier to negotiate international agreements with other States or international organizations on behalf of the occupied territory? Are there restrictions on the means an occupier may use for administering the occupied territory?

Is there a need to ensure reviewability/monitoring of the measures taken by the occupant under Article 43 of THR and Article 64 of GCIV? Who would be responsible for reviewing the occupiers' measures?

\section{Working session 2: The role of international human rights law in occupied territory}

What triggers the application of human rights law in occupied territory? If a form of control is required to apply human rights law in occupied territory, does control under IHL mean a similar type and level of control as under human rights law? What is the nature of the relationship between IHL and human rights law in situations of occupation? What is the influence of human rights law on occupation law? And vice versa?

Is there a right or an obligation under IHL to apply human rights law in occupied territory? Do IHL provisions, in particular Article 43 of THR, entail an obligation to respect and ensure respect for human rights law in occupied territory, as suggested by the ICJ in the case of Democratic Republic of the Congo v. Uganda?' Are human rights obligations applicable from the beginning of the occupation or do they apply only after a certain period of time?

\footnotetext{
ICJ, 19 December 2005, Armed Activities on the Territory of the Congo (Democratic Republic of the Congo v. Uganda), $\$ 178$
} 
If human rights law applies, to what extent must it be respected, protected and fulfilled? Do all human rights obligations apply fully in situations of occupation? In particular, how can economic, social and cultural rights be implemented in occupied territory? How do human rights obligations - which may entail important legal and structural reforms - mesh with the conservationist principle intrinsic to occupation law?

Can human rights law be derogated from in occupied territory? Can the notion of "public emergency which threatens the life of the nation," as contained in Article $4 \$ 1$ of the International Covenant on Civil and Political Rights, be invoked by the occupier? Does the occupier need to derogate from its human rights obligations in order not to apply them in occupied territory?

\section{Working session 3: Transformative occupation}

Does IHL permit or preclude transformative occupation? Does the obligation to administer the occupied territory encompass a power to craft structural reforms, in particular in the institutional and constitutional fields?

Can the status quo ante intrinsic to occupation law always be maintained? Is there any exception to this principle? Is the conservationist principle still relevant in the case of occupation of a decaying/collapsed State? Can transformative occupation be carried out if the subsequent changes do not affect the protection afforded by IHL to the local population? Are the legitimacy and the extent of the reforms that can be permitted linked to whether they find justification in other fields of international law?

What is the contemporary rationale for the conservationist principle, if any? Does it still demarcate the border between the rights of the occupier and a de jure sovereign?

Can the Security Council require or justify transformative occupation? Under what circumstances? Does transformative occupation necessarily require the Security Council's approval?

Can human rights law, in particular the right to self-determination, serve as a basis for pursuing transformative policies in occupied territory? Can the occupier replace one set of institutions by another that is necessary to protect human rights?

Is there any necessity for IHL to evolve so that it accommodates transformative occupation? Is this desirable? How should IHL accommodate this reality? Should it espouse general principles of what reforms are permitted or describe more permissible and impermissible reforms in detail?

\section{Working session 4: Long-term occupation}

Are the implementation and interpretation of Article 43 of THR and Article 64 of GCIV affected by the duration of an occupation? Does long-term occupation oblige the occupier to take steps to promote the development of the occupied territory? Can those obligations be interpreted as imposing upon the occupier an obligation to administer the occupied territory "for the benefit of the occupied population"?

How can the conservationist principle be reconciled with long-term occupation? Since limiting the occupier's powers is indicative of the temporary character of occupation, does protracted occupation mitigate such limitations? Can long-term occupation justify more changes by the occupier in occupied territory? If yes, what would be the criteria for such changes and the limits to them?

Is there any relationship between the implementation of human rights in occupied territory and protracted occupation?

What is the nature of the relationship between Article $6 \$ 3$ of GCIV and long-term occupation? In this regard, what bearing does the 2004 ICJ advisory opinion on the Wall have?2 Did the advisory opinion revive Article $6 \$ 3$ of GCIV? Or is the Article still a legal oddity? 


\section{DAY TWO}

\section{THE RELEVANCE OF OCCUPATION LAW FOR UN ADMINISTRATION OF TERRITORY}

\section{Working session 1: The threshold questions of de jure applicability of occupation law}

Is occupation law applicable de jure to UN administration of territory? Can the UN ever be considered an occupier? Does either the source of authority or purpose of a UN administration per se make occupation law inapplicable de jure to such situations?

Does the traditional criterion for occupation, of lack of consent to the presence of the occupier, apply to UN territorial administration? If so, what sort of indicia for consent ab initio render occupation law inapplicable de jure? How should such consent be determined in territory with no effective government?

Assuming such consent is achieved ab initio, what sort of change in circumstances on the ground would justify the application of occupation law de jure after a UN administration has already started?

Do the general criteria for exercise of effective control of territory apply to UN administrations, especially in light of the large civilian presence? What if the UN mission has no military contingents or relies upon the military presence of other international actors? If foreign forces not part of the UN administration gained control of the territory, who would be bound by occupation law?

\section{Working session 2: Reconciling occupation law with a Security Council mandate}

If a UN operation meets the threshold criteria for de jure application of occupation law, can the Security Council legally override all or part of occupation law? If the latter, which parts?

Are any parts of occupation law jus cogens and would the Security Council have any authority to override them?

Assuming the Security Council has the authority to override occupation law, how specific does the Security Council need to be in its authorizing resolution to do so? Does it need to mention the inapplicability of occupation law or can the mandate of the mission implicitly override certain norms of occupation law?

Are there any other general principles for determining whether occupation law is compatible with the Security Council's mandate?

\section{Working session 3: Application of specific norms of occupation law by UN operations}

Do certain norms of occupation law seem especially helpful to UN administrations even if not applicable de jure? Do certain classes of these norms seem irrelevant?

How specifically should UN administrators adjust norms of occupation law to take into account the goals of the mission or other norms of international law, such as human rights law? Does the usefulness of occupation law change over the course of the mission?

What are the overall costs and benefits to both IHL and the UN's purposes of applying part but not all of occupation law as a matter of policy, or, alternatively, as a source of inspiration for policy?

\section{Working session 4: Application of specific norms of occupation law by UN operations}

Is there any need for a detailed legal regime (through treaties, UN resolutions, or other means) on UN governance of territories that would place the UN's mandate, IHL, human rights law, other international law, and local law in a framework specifying when and how each would govern a particular issue?

Would the UN benefit from a further set of guidelines on the role of occupation law in UN territorial administrations? 


\section{APPENDIX 4 \\ LIST OF PARTICIPANTS}

1. Prof. M. A. Al Wafa, Cairo University

2. Prof. M. Bothe, Johann Wolfgang Goethe-Universität, Frankfurt

3. Ms L. Cameron, University of Geneva

4. Prof. J. Cerone, New England School of Law

5. Col (retd) C. Garraway, Associate Fellow, Chatham House

6. Prof. R. Kolb, University of Geneva

7. Dr B. Oswald, University of Melbourne

8. Prof. A. Paulus, Georg-August University of Göttingen

9. Prof. S. R. Ratner, University of Michigan Law School

10. Prof. A. Roberts, University of Oxford

11. Mr J. Ross, Legal and Policy Director, Human Rights Watch

12. Prof. M. Sassolì, University of Geneva

13. Dr I. Seiderman, Senior Legal and Policy Adviser, International Commission of Jurists

14. Dr C. Shamas, Senior Partner, The Mattin Group, Jerusalem/Ramallah

15. Prof. Y. Shany, Hebrew University of Jerusalem

16. Dr D. Shraga, Principal Legal Officer, Office of Legal Affairs, United Nations

17. Prof. Y. Sandoz, Geneva Academy of IHL and Human Rights, Member of the ICRC

18. Dr P. Spoerri, Director for International Law and Cooperation within the Movement, ICRC

19. Dr K. Dörmann, Head of the Legal Division, ICRC

20. Mr L. Colassis, Deputy Head of the Legal Division, ICRC

21. Dr S. Vité, Legal Adviser, ICRC

22. Dr T. Ferraro, Legal Adviser, ICRC 


\section{THIRD MEETING OF EXPERTS: THE USE OF FORCE IN OCCUPIED TERRITORY 29-30 OCTOBER 2009, GENEVA}

One of the most important challenges in contemporary occupations is ascertaining how and when law enforcement rules, as against the rules governing the conduct of hostilities, apply to the use of force by the occupying power. Under Article 43 of the Hague Regulations, the occupying power has an obligation to provide - as far as possible - security in occupied territory by maintaining public order, quelling riots and disturbances, and enforcing the law against criminal acts. Thus, besides enforcing its military authority, the occupying power is required by occupation law to exercise police powers in the territory under its effective control.

Implementing Article 43 of the Hague Regulations, which has always been regarded as the central provision of occupation law, remains difficult, operationally and legally. As recent occupations have shown, regulating the use of force in response to civil unrest and ongoing armed opposition is not a clear-cut matter. Although the occupier is required to ensure security by means of law enforcement, a great deal of uncertainty remains about the legal regimes applicable in situations where it is difficult to distinguish hostilities from civil unrest or where the occupying power is confronted by both at the same time in parts of, or the entire, occupied territory.

Although they entrust the occupying power with the important task of maintaining public order and safety, and although they also recognize the occupying power's right to carry out military operations in parallel, the Hague Regulations and the Fourth Geneva Convention do not spell out when and how force may be used in occupied territory. In fact, occupation law is silent on the separation and interaction between law enforcement measures and the use of military force under the 'conduct-of-hostilities' model. And it gives no concrete direction for confronting resistance movements and other armed opposition militarily. In fact, occupation law leaves unresolved a number of issues related to the identification of the legal regime(s) governing the use of force in occupied territory. This inevitably permits various interpretations to be made regarding the use of force: how that may be done, in what circumstances and under which body of law. Ultimately, this uncertainty about the legal regime applicable might affect the protection afforded to the local population.

Practice unambiguously shows that the use of force by the occupying power can be based on either of two models. The first relates to law enforcement activities carried out within the framework of Article 43 of the Hague Regulations. This model assumes that the foreign authority has a relatively secure hold on the occupied territory, where it seeks to ensure that the rule of law is upheld. The second model, which applies exclusively to the conduct of hostilities, is based on the premise that organized armed groups or the occupied State's armed forces that remain are still committing violent acts or that they have resumed doing so.

Based on the fundamental distinction between these two models, one could argue that their rules and standards governing the use of force are also inherently dissimilar. The law enforcement model imposes stricter standards on the occupying power by prohibiting it from arbitrarily depriving individuals of their right to life. This means that the occupying power is authorized to use lethal force - while exercising its policing functions - only under very strict circumstances. In fact, under this model, the occupying power may use lethal force only when this is strictly unavoidable in order to protect life and when less extreme means are insufficient for achieving that objective. The second model - which relates to the conduct of hostilities - provides more leeway to the occupying power for using force. During hostilities, occupying forces are normally permitted to attack enemy combatants as well as civilians directly participating in the fighting. The law of armed conflict also does not prohibit - albeit under strictly pre-established conditions - civilian losses to a certain extent, often described broadly as "collateral 
damage."1 In other words, although the use of lethal force can prove to be perfectly compatible with the legal requirements of both models, it should remain the exception in the course of law enforcement activities, while it is inherent to the conduct of hostilities.

The theoretical construct described above does not, however, provide any further guidance for determining which of these models applies in situation of occupation, and this is a significant obstacle. Making that determination is essential with regard to the use of force in occupied territory, because the two models may apply concurrently and end up with quite distinct results. In fact, the occupying power may be engaged in the conduct of hostilities (for instance, against the enemy armed forces that remain or other organized armed groups), but it may also be carrying out, at the same time, law enforcement tasks as required by occupation law (such as quelling spontaneous demonstrations by the civilian population). In such circumstances, the challenge will be to identify when each model applies and when it is necessary to switch from one to the other. One would also have to consider whether the occupying power is capable of taking, or obliged to take, law enforcement measures against members of organized armed groups instead of directly using deadly force under the 'conduct-of-hostilities' model.

An additional challenge arises from the necessity of identifying precisely the rules governing law enforcement in a situation of occupation. One would have to determine whether the rules and standards governing the use of force in law enforcement operations derive from human rights law, IHL or some combination of these two bodies of law.

\section{Main points addressed during the meeting of experts}

\section{PART ONE: DELIMITING THE LEGAL FRAMEWORK APPLICABLE TO THE USE OF FORCE IN OCCUPIED TERRITORY}

After an introductory presentation that identified the main legal issues and some ways of tackling the challenges posed by the subject under scrutiny, the participants got the discussion under way by agreeing about certain facts: occupation law does not provide clear-cut directions for the occupying power on resorting to force, including lethal force, in occupied territory. Neither the Fourth Geneva Convention nor the Hague Regulations directly addresses the issue of policing - with the exception of a broad reference in Article 43 of the latter - or its interrelationship with the conduct of hostilities in occupied territory. Some experts remarked that human rights law, too, was virtually silent on what it required from the occupying power using force against its adversary in situations of armed conflict, including occupation. The participants declared that this absence of real guidance was causing great confusion and leading to conflicting interpretations. As a result, a significant amount of leeway was being granted de facto to occupying powers in the use of force in occupied territories, which could jeopardize the protection afforded by IHL to those affected by the occupation. The participants acknowledged the legal difficulties surrounding the use of force in occupied territory; they noted that the use of force made it necessary to consider the interaction between various legal regimes, as well as between various models (law enforcement and 'conduct-of-hostilities'), and that this was what gave rise to the various difficulties. All this, they said, made further clarification in this regard a necessity. In order to determine more precisely the rules governing the use of force in occupied territory, the experts first considered how to delineate the various legal frameworks applicable.

\section{A. DEFINING THE LEGAL REGIMES APPLICABLE}

The experts identified five different legal sources that could be of relevance for determining the legal framework governing the use of force in occupied territory.

First, the experts agreed, IHL, in particular the rules governing occupation and the conduct of hostilities, would form the first layer of relevant legal provisions. However, some experts pointed out that occupation law (in particular, Article 43 of the Hague Regulations, which outlines the occupier's duties vis-à-vis the maintenance of law and order) would provide only a general 
background against which to examine the use of force. It could not, in the absence of detailed rules that address the issue specifically, serve as the legal framework for policing an occupied territory.

Second, a majority of the experts pointed out the importance of human rights law in relation to the use of force by the occupying power. The question of the extraterritorial applicability of human rights law gave rise to a lively discussion. However, a majority of the participants agreed that human rights law would unavoidably apply in occupied territory, as international jurisprudence, particularly that of the ICJ, showed. ${ }^{2}$ These experts held that application of the relevant human rights law rules was justified, in particular on the basis of the 'State agent authority' and 'effective control' tests. They asserted that effective control for the purposes of occupation law would be, per se, sufficient basis for establishing jurisdiction under human rights law. The experts also drew attention to the distinctive role played by human rights law in this context, as they took the view that IHL was vague about the conditions under which the occupying power should undertake its policing functions in the occupied territory. Some experts considered human rights law to constitute the lex specialis in relation to the law enforcement tasks of the occupying power, while others regarded it as only complementing the relevant provisions of occupation law, in particular Article 43 of the Hague Regulations.

Third, jus ad bellum was cited by one expert as an important set of rules for determining the legal framework that would govern the use of force in occupied territory. This participant declared that, in order to use force in occupied territory, the occupying power had to find an enabling norm. The same participant - who took into account that occupation and its correlative concept of effective control assumed the existence of some degree of stability and that occupation law was silent on the possibility of, and conditions for, the resort to force in occupied territory - asserted that the permission to use force should necessarily stem from jus ad bellum. This assertion was contested by most of the experts, who said that jus ad bellum should be kept strictly separated from jus in bello and consequently was not relevant for the issues addressed within the framework of this meeting. In addition, they declared that the occupying power's authority to use force in the territory under its effective control could not be questioned as it was inherent to the state of occupation, since the latter constituted a form of international armed conflict. These experts then declared that the search for a specific and explicit norm enabling the occupier to use lethal force was thus not necessary. They said that the main question was not whether the occupying power could use force in occupied territory but rather when, and under what conditions and standards.

Fourth, two experts drew attention to the relevance of the occupying power's domestic law: they said that it was the decisive element in determining the armed response to a given threat, even when that threat materialized in occupied territory. They argued that concepts such as self-defence or the escalation of force, as well as other standards governing the use of force, should be sought in the occupying power's domestic law and not in international instruments such as occupation law or human rights law. They stressed that the occupier's domestic law should be part of the use-of-force equation. Another participant, after acknowledging the relevance of the foreign power's domestic law, said that it must not be forgotten that the occupying power could not invoke provisions of its domestic law to justify its failure to meet the obligations of international law applicable in occupied territory, in particular those stemming from occupation law and human rights law when applicable.

Finally, some experts brought up the possibility of the domestic law of the occupied territory regulating the use of force by the occupying power. In particular, some experts asserted that the duty incumbent upon the occupier to respect the laws in force in the occupied territory, contained in Article 43 of the Hague Regulations, would introduce another layer of norms that the occupying power would have to observe when resorting to force (particularly the rules of human rights law incorporated in the occupied territory's domestic legal order). This position was openly challenged by one participant - who was joined by several others - on the grounds that it was based on a misinterpretation of Article 43. In fact, this expert was of the opinion that the idea that Article 43 required the occupied power to comply with the domestic law of the occupied territory was mistaken. He said that the provision merely indicated that the people of the occupied territory should be able, as far as possible, to continue to live under their own legal order. Furthermore, if the domestic law of the occupied territory contained obligations that went beyond the occupier's obligations under international law or placed additional limitations on the use of force, so as to threaten the occupier's security or obstruct the implementation

\footnotetext{
For dissenting opinions on the issue of the extraterritorial application of human rights law, see infra.
} 
of its duty to maintain public order and safety, the occupier would be entitled to abrogate or suspend these domestic measures by virtue of Article $64 \$ 1$ of the Fourth Geneva Convention. As a consequence, these experts rejected the idea that the domestic law of the occupied territory had a role in the legal framework governing the use of force by the occupying power.

Although they found five legal frameworks to be potentially of relevance, most of the experts agreed that IHL and human rights law were the main regimes to take into account while determining the rules governing the use of force in occupied territory.

The experts then drew attention to the necessity of finding ways to define precisely the model - and its correlative rules - that would govern the use of force in occupied territory. They said that this was essential because the standards governing the use of force varied according to the model applicable, the standards in force under the 'conduct-of-hostilities' model being more permissive than those prevailing under the law enforcement model. As some experts pointed out, the policing of a territory involved the use of force in a manner that was fundamentally different from conducting hostilities within the meaning of IHL.

\section{B. THEORIES AND CONDITIONS FOR DETERMINING THE LEGAL MODEL APPLICABLE}

Given the fundamental distinctions between the law enforcement and 'conduct-of-hostilities' models, the experts proceeded to identify various circumstances that could help to define precisely when and how each would apply in occupied territory. Their discussions revealed a basic difference of opinion among the participants: one set supported an approach based on the exclusive application of one model throughout the occupied territory (the so-called 'either/or' theory) while another favoured an approach that permitted simultaneous application of both models.

One expert explained that the 'either/or' approach was based on the premise that a territory was either under the effective control of the occupying forces or in a state of 'hot' armed conflict. In other words, no territory could be an occupied territory in legal terms and the site of hostilities at the same time. Taking this approach resulted in the emergence of two distinct scenarios that necessitated the application of different models.

First, it was suggested that the exclusive application of the law enforcement model would prevail because the effective control exercised by the occupying power would stabilize the situation in the occupied territory. One expert pointed out that the prevalence of the law enforcement model was based on an assumption derived from norms of occupation law. He asserted that Articles 5 and 68 of the Fourth Geneva Convention in particular implied that the occupying power would not be entitled to resort to rules on the conduct of hostilities in situations where individuals in the occupied territory were threatening its security. Rather, these provisions assumed that the persons in question would be captured and tried. Moreover, this expert declared, the strict distinction envisioned by the Hague Regulations between the rules on the conduct of hostilities in their Section II and those on occupation in their Section III implied the primacy of the law enforcement model over the 'conduct-of-hostilities' model in situations of occupation.

This assumption was rejected by other participants, who emphasized that there was no legal basis for inferring the prevalence of the law enforcement model. They declared that it was not possible to limit the legal framework applicable to occupation to human rights law and the sections of the Hague Regulations and the Fourth Geneva Convention dealing with occupied territories. They argued that the range of IHL norms applicable would be much broader and encompassed the rules governing hostilities, provided certain conditions were fulfilled. In this regard, two experts suggested that a number of IHL norms, such as Articles 49\$2, $49 \$ 5$ and 53 of the Fourth Geneva Convention, contemplated the potential application of the 'conduct-of-hostilities' model in occupied territories. Therefore, these provisions confirmed that the drafters of the Fourth Geneva Convention had envisaged the existence of a state of hostilities in occupied territory and the correlative application of specific IHL norms governing such a situation.

Second, it was emphasized that the 'either/or' approach could also lead to the exclusive application of the 'conduct-of-hostilities' model vis-à-vis any use of force in the occupied territory. This option would be 
chosen particularly when the threats emanating from the enemy's armed forces and/or affiliated armed groups had not yet been definitively suppressed. Such a scenario was considered to be particularly advantageous for the occupying power, as it would relieve it from the strictures of law enforcement rules. The 'either/or' approach was clearly rejected by most of the experts, who asserted that the mere fact that occupation might trigger an international armed conflict does not justify per se permanently preferring the 'conduct-of-hostilities' model to the law enforcement model. In fact, the experts said, the occupier's duty under IHL to police the occupied territory would not necessarily disappear with the continuation or the resumption of armed violence there. Any use of force in connection with this policing duty would have to be governed by the law enforcement model rather than that related to the conduct of hostilities.

These experts were of the opinion that no analysis of the legal framework governing the use of force in occupied territory could rely on the 'either/or' theory. They also argued that privileging one model over the other would not provide an effective means of coping with the complexities arising from occupation and the correlative use of force by the occupying power.

In support of this position, some experts pointed out that the situation in occupied territory was usually very complex, as some areas could be the site of hostilities while others could be comparatively calm, a consequence of the occupying power's efforts to restore stability. The recurrent oscillation between periods of hostilities and of calm, or even their coexistence, justified rejecting the excessively dogmatic 'either/or' approach. The exclusive application of the law enforcement model was thus deemed inadequate for dealing with the scale of violence that usually characterized hostilities between the occupying power and the local armed forces and/or affiliated armed groups: situations of this kind would be governed more effectively by the 'conduct-of-hostilities' model and its looser rules on the use of force. The participants also acknowledged that exclusive application of the 'conduct-of-hostilities' model would be impracticable, given the kind of activities that came under the occupier's duty to ensure public order and safety in the occupied territory.

The experts agreed that law enforcement's stricter standards were better suited to regulating all use of force in relation to the policing activities conducted by the occupying power. Therefore, given that they were dealing with situations likely to be complex and many-sided, the experts came to agree about the complementarity of the law enforcement and 'conduct-of-hostilities' models, and about their simultaneous application, in occupations, depending upon the circumstances faced by the occupying power.

Spurred by the developing consensus on the "simultaneous application" option, the experts said that it was necessary to delineate the circumstances in which the two models would operate in occupied territory. ${ }^{3}$ They sought to identify criteria that would both justify the application of one of the two models to a specific action or situation and permit the transition between them. To that end, three different approaches were proposed.

\section{1. "Situation-based" or "sliding scale" approach}

First, some experts expressed support for a so-called "situation-based" or "sliding scale" approach, according to which the choice and application of the model would be based on the situation prevailing at the time the occupying power decided to resort to force. Its proponents claimed that this approach would allow for a smooth transition between the two models: the point of transition would depend on the level of threat faced by the occupying power. It would also permit the occupying power to adjust the use of force to the situation. ${ }^{4}$

This approach was supported by some participants, but criticized by others who challenged the possibility of such a smooth transition between law enforcement and the conduct of hostilities. These experts also asserted that the approach ignored basic differences in the

3 One expert contended that it would always be very difficult to identify precisely the model applicable and the correlative rules. He proposed that key principles be extracted from various applicable bodies of law and used as a set of practical guidelines to be applied by the occupying power when resorting to force. The expert said that this would enable us to move away from the rigidity of the separation of the law enforcement and 'conduct-of-hostilities' models. This proposal was rejected by the other participants because of the fundamental differences between the rules governing law enforcement and those applicable to the conduct of hostilities (see infra).

4 According to its supporters, only the "sliding scale" theory - with its inherent case-by-case approach - took into account the simultaneous application of IHL and human rights law in occupied territory, and the impossibility of establishing that one regime would always prevail over the other as a matter of lex specialis. 
two models and would eventually result in blurring the distinction between IHL and human rights law.

To put the "sliding scale" theory into practice, its supporters said, it was necessary to identify the conditions or factors for determining which model - law enforcement or 'conductof-hostilities' - would prevail in a specific situation. Since IHL was held to be silent on the "conversion factors" that permitted a switch from the law enforcement model to the 'conduct- of-hostilities' one and vice versa, the experts set out to identify some of these factors.

Three experts insisted that the nature of the threat faced by the occupying power should determine the model applicable. In particular, they said, a threat emanating from insurgent groups - organized to a degree that permitted them to conduct military operations against the occupying power - should be dealt with under the 'conduct-of-hostilities' model. These experts argued that it was the only model that would permit the occupying power to quell the threat in question. Thus, taking this approach meant making a choice of model based on the status of individuals within the meaning of IHL. Consequently, the experts proposed that the use of force against combatants, members of organized armed groups and individuals directly participating in hostilities be governed by the rules contained within the 'conduct-of-hostilities' model. ${ }^{5}$

The experts also pointed out that differences in the level of control exerted by the occupant within the occupied territory would have an impact on choosing the model to be applied. The implementation of law-and-order activities would require a significant degree of control over the area or situation under scrutiny. The experts argued that variations in control in the occupied territory, as exemplified by the Oslo agreements between the Palestine Liberation Organization and Israel, would inevitably require the occupying power to reconsider its responses to threats posed by insurgent armed groups. According to some participants, in areas of operation where the occupying power was "firmly in control," application of the law enforcement model was indicated. On the other hand, some experts were of the view that the 'conduct-of-hostilities' model should apply in areas where occupying forces have less control, where it would be very difficult to capture members of enemy forces without exposing the occupying troops to increased risks and where the immediate danger posed by the enemy would be greater.

One participant said that the duration of occupation should also be taken into account, since that could also be influential in determining the normative framework applicable to the use of force in occupied territory. He argued that when the occupation endured, the 'conduct-of-hostilities' model would come to be gradually replaced by the law enforcement model. Because violence between the occupying forces and local armed forces and/or organized insurgent groups should subside with the passage of time, it might be expected that the law enforcement norms associated with more peaceful governance would apply. However, this was challenged by two experts who pointed out that recent instances of protracted occupation showed that hostilities could continue or resume at any time. Therefore, they argued, duration was not a valid "conversion factor."

Some experts also claimed that the nature of the occupation could have an influence in determining the model applicable. They drew a distinction between "calm" and "troubled" occupation and claimed that the law enforcement model should be applied to the former and the 'conduct-of-hostilities' model to the latter. They said that in "calm" occupations, the seriousness and immediacy of the threats faced by the occupying power would usually necessitate the application only of law enforcement standards since it could be assumed that enemy armed forces and/or affiliated armed groups had been disarmed and disbanded. These experts found no reason to apply the 'conduct-of-hostilities' model when no insurgency

However, two experts emphasized that in certain situations it would continue to be impossible for the occupying power to determine whether a particular person belonged to insurgent groups dealt with under the 'conduct-of-hostilities' model. The experts cited a hypothetical example: How should soldiers at a checkpoint respond to persons of unknown status who were driving towards them in a suspicious manner? In such instances, the experts declared, the threat in question should be dealt with in accordance with the 'escalation-of-force' rule, without directly opting for the use of lethal force under the 'conduct-ofhostilities' model. 
existed and when there was no resistance from the armed forces of the local government. They declared that the 'conduct-of-hostilities' model could be used only in cases of "troubled occupation" where the effective control exercised by the occupying forces was still being militarily challenged by local armed forces and/or affiliated armed groups.

The experts then considered a second approach to identifying criteria for determining the model applicable to the use of force.

\section{2. "Mixed model" approach}

One expert proposed a "mixed model" approach, which borrowed from both IHL and human rights law to address the unique situation created by the occupation. ${ }^{6}$ This expert claimed that the "mixed model" approach enabled the reconciliation of IHL and human rights law with regard to the use of force and reflected the idea of cross-interpretation between the two bodies of law. He contended that the occupying forces were permitted to resort to lethal force against fighters provided certain requirements were fulfilled, in particular not using lethal force if less harmful means were available and setting up an ex post facto investigation each time lethal force was used.

Some participants found the "mixed model" approach attractive, but others questioned its viability, claiming that it would not withstand the actualities of the situation. They pointed out that the "mixed model" dispensed with the essential task of distinguishing between the conduct of hostilities and situations of law enforcement or individual self-defence. Furthermore, some of the experts asserted, the "mixed model" approach would lead to a threat-based use of force, which would essentially ignore the fact that IHL required the parties to a conflict to target the enemy on the basis of her or his personal status without assessing whether he or she posed an immediate threat to the occupying forces. As a result, some experts felt that the approach was ineluctably doomed to be opposed by States.

\section{The "jump theory"}

Some experts said that the transition between the law enforcement and 'conduct-of-hostilities' models was not as straightforward as suggested by the "sliding scale" approach. In fact, to shift from the law enforcement to the 'conduct-of-hostilities' model, one would need a "jump" or a "break." According to this position, given their fundamental differences, one could not expect a smooth transition between the law enforcement and 'conduct-of-hostilities' models. Instead, switching to the 'conduct-of-hostilities' model, which enabled the use of force against individuals based solely on their personal status, necessitated the existence of specific conditions that would activate IHL's more permissive rules. One expert, supported by others, said that this "jump" or "break" would materialize through the fulfilment of the criteria used to assess the existence of a non-international armed conflict: the degree of organization among the parties involved and the intensity of the armed confrontation. If these criteria were observed in relation to the confrontation between the occupying forces and organized armed groups not "belonging to" the government of the occupied territory, the occupying forces would be entitled to resort to force under the 'conduct-of-hostilities' model in order to suppress the threat posed by such armed resistance. ${ }^{7}$

Thus, the discussions revealed that the experts were divided about the approach to be chosen. The "mixed model" approach was clearly rejected; but neither the "sliding scale" approach nor the "jump" theory won a clear majority among the experts.

However, the experts agreed that the use of force and the identification of the pertinent normative framework should ultimately be based on the prevailing facts; it should not be constrained by a dogmatic approach to applying the law. In fact, a majority of experts affirmed that the context should always determine which of the two models should be applied. They

This approach was reflected, notably, in a famous decision of the Supreme Court of Israel in December 2006, HCJ 769/02, Public Committee Against Torture in Israel (PCATI) et al. v. Government of Israel et al.

7 The experts interpreted the notion of "belonging to" within the meaning of Article 4.A.2 of the Third Geneva Convention. Therefore, the criteria put forward by the proponents of the so-called "jump theory" would be used only when the nature of the confrontation between the occupying forces and organized armed groups failed to meet the conditions set out in Article 4.A.2 of the Third Geneva Convention, even if the armed groups claimed to be fighting on behalf of the occupied State. 
argued that each model could apply in the appropriate circumstances. In addition, the experts said, even if one model is preferred, the other would be held in reserve, as it were, to be applied when required.

No consensus was reached on which approach to prefer, but eventually a majority emerged about the need - within the framework of the option of applying the two models simultaneously - to establish law enforcement as the default model in relation to the use of force in occupied territory. The experts said that, except when it was clear that the threat to the occupying power came from the armed forces of the occupied territory and/or affiliated armed groups, making the IHL rules on the conduct of hostilities the lex specialis, the application of law enforcement rules and standards should be presumed. Some experts drew a parallel between occupation and a hypothetical situation in the occupying power's own territory that required identification of the conditions in which force could be resorted to. The experts contended that even if occupation did not imply a transfer of sovereign title, the fact that it entailed a temporary transfer of authority and acts of governance, including the maintenance of law and order as required by Article 43 of the Hague Regulations, pointed towards the application of law enforcement as the default rule. One expert also pointed out that the concept of effective control and the underlying idea of stabilization would appear to suggest that "calm" occupation would be the rule and "troubled" occupation the exception, thereby justifying the presumption of application of the law enforcement model.

Regarding the matter from a different perspective, one participant said that the difficulty of distinguishing combatants from "peaceful civilians" in occupied territory and related doubts about the status of individuals potentially subject to the use of lethal force justified per se opting for the application of the law enforcement model. Finally, another expert explained that the decision to apply the law enforcement model could also be made for political purposes, because the application of its stricter standards on the use of force might be better suited to achieving the occupier's objective of winning the 'hearts and minds' of the local population. Faced with these arguments, a majority of the experts concluded that application of the law enforcement model should be presumed in occupied territory. This presumption was nonetheless regarded as rebuttable in favour of the 'conduct-of-hostilities' model if certain conditions were fulfilled.

\section{THE ROLE OF HUMAN RIGHTS LAW IN REGULATING THE USE OF FORCE IN OCCUPIED TERRITORY}

After the discussion about determining the applicable model had concluded, two experts strongly defended the relevance and even the prevalence of the human rights regime on the grounds that it could govern the use of force in all circumstances. They based their argument on the fact that while IHL and human rights law applied simultaneously in occupied territory, the former should not necessarily be considered the lex specialis derogating from the latter in its entirety. In fact, the two experts contended, IHL should be regarded as only a complementary body of law, since human rights law would generally provide adequate and sometimes more precise answers to issues linked with the use of force in occupied territory.

These experts then asserted that a comparison between IHL and human rights law would demonstrate that the differences between them would not result in substantially different outcomes. Although the human rights regime would generally go a bit further in terms of protection - as it was based on a peacetime paradigm - the differences between the two bodies of law in this regard were only a matter of degree. One expert added that these slight differences tended to disappear progressively under the decisions of human rights bodies, in particular the European Court of Human Rights, which were developing a set of human rights applicable in and adjusted to the particularities of armed conflict. The experts argued that therefore the human rights regime would also apply to relationships between belligerents.

The two experts then explained that even though this trend had developed mainly in the context of non-international armed conflict, its rationale could also be transposed to situations of occupation. They said that the prevalence of human rights law was all the more justified by the fact that it could simultaneously govern the activities of law enforcement and military operations, both of which were 
usually carried out by the occupying power while exercising effective control of the foreign territory. The experts then praised the flexibility of human rights law, the rules and standards of which could easily be adjusted to the broad range of situations faced by the occupying power. This flexibility was characterized particularly by the fact that under human rights law the resort to force was assessed in terms of the level of control exerted by the occupying forces over a specific situation and the level of threat they faced. Resort to human rights law would prove particularly useful when the occupying forces were not in a position to establish with certainty whether a hostile act or threat was linked to the armed conflict. ${ }^{8}$

The two experts also said that it was extremely important to do away with the misconception that human rights law would apply only to law enforcement operations because its standards were too strict to govern the conduct of hostilities. For these experts, this was not the case since standards such as necessity or immediacy could readily be interpreted more leniently in light of the circumstances of a given armed conflict, leading to force being used in such a way that its consequences were similar to those resulting from the application of the 'conduct-of- hostilities' model. One of the interesting aspects of human rights law in relation to occupation - also put forward by supporters of the prevalence of this legal regime - was that under it, the use of force would not depend on the status of those against whom the force could be used. This would assist in overcoming the difficulty of distinguishing between fighters and civilians, which is required under the 'conduct-of-hostilities' model, and always difficult to do in situations of occupation.

The experts also drew attention to the additional advantages stemming from the application of the human rights regime in relation to the use of force. They contended that human rights law created obligations complementing those set forth under IHL, notably the systematic submission of reports on military operations, the establishment of a presumption of responsibility for the occupying power when lethal force was used, and the implementation ex post facto of investigations whenever someone was killed in the course of the occupier's operations. In closing, the experts pointed out that the application of the human rights regime each time the occupying power resorted to force would make it possible to import monitoring mechanisms into situations of occupation. This would significantly increase protection for individuals during armed conflict, as it would effectively increase the occupier's accountability, thus filling an important gap in occupation law. ${ }^{9}$

The two experts concluded by saying that the flexibility of human rights provisions pertaining to the use of force would permit their application in almost all situations confronting the occupying power, ranging from enforcing the law against criminal acts such as robbery or drug trafficking to open hostilities pitting the occupying forces against insurgent armed groups. The experts argued that this would in itself justify regarding the human rights regime as the central piece of the legal framework governing the use of force in occupied territory.

These views were vigorously contested by other participants, who went so far as to challenge the overall relevance of human rights law to the issue at hand. They stated emphatically that the extraterritorial reach of human rights law should not be taken for granted as others had suggested. They said that one should not assume, despite the jurisprudence of the European Court of Human Rights, that States would necessarily accept the extraterritorial application of human rights law, particularly when exercising effective control. In fact, some experts said, State practice, notably that of occupying powers - past and present - did not reflect any acceptance of the applicability of human rights law; it did, however, reflect their vigorous resistance to the idea. ${ }^{10}$ Therefore, some participants suggested, it would be wise not to underestimate States' opposition to the application of human rights law in occupied territory. These experts also warned against having an excessively Eurocentric view of the issue of the extraterritorial application of human rights law; they said that it was necessary to take a different approach, one that more faithfully reflected States' positions and occupiers' practice. Playing the devil's advocate, one expert even argued that there was no need to

8 The experts also said that they had proposed applying the human rights regime because it would eliminate the difficulty arising from having to classify, for the purposes of IHL, the nature of the hostilities in occupied territory - in particular, having to assess the intensity of the violence.

9 Indeed, one of the main deficiencies in occupation law is the absence of any mechanism of control and accountability for the measures taken by the occupying power in occupied territory.

10 Two experts pointed out that the lack of consistency in States' practice vis-à-vis the extraterritorial application of human right law was such that it would be difficult to draw any conclusion from it concerning the applicability of human rights law abroad. 
hasten to find justification in treaty law for the application of human rights law in occupied territory, since Article 75 of Additional Protocol I, viewed as a norm of customary law, would provide for the incorporation under IHL of the main principles of human rights law. Another participant pointed out that the application of provisions of human rights law in situations of armed conflict through their inclusion in IHL norms would be decidedly more palatable for States still opposing the extraterritorial reach of human rights law. This proposal was deemed by many present to be a satisfactory way to bridge the gap between those who supported the application of human rights law in occupied territory and those who favoured the exclusive application of IHL.

Some experts also vigorously questioned the emphasis other participants had put on the similarities between the human rights regime and IHL, not only in terms of governing principles but also in terms of practical results. Many of the experts were of the opinion that there still existed sharp differences between IHL and human rights law, in their general rationale and in their core rules. In particular, it was submitted that the logic governing the use of force under a law enforcement model based on human rights law could not be compared to that under a "conduct-of-hostilities" model; they differed significantly owing to the different circumstances their respective norms were intended to address: armed conflicts for IHL and peacetime for human rights law. Furthermore, one expert declared, the two regimes differed in their approach to the use of force: while human rights law regarded the use of force from an individualized perspective, IHL took a broader, collective approach to the use of force in connection with the confrontation between two organized armed groups.

The experts also shed some light on the differences between the rules and standards governing the two models and the two legal regimes. The law enforcement model emphasizes limiting the use of force to situations of absolute necessity. The experts pointed out that lethal force could be intentionally employed only in circumstances where it was strictly unavoidable. They said that the law enforcement model expressed a clear preference and called for capturing rather than killing a suspect, its objective being to limit not only intentional killing but also unintended deprivation of life. As one expert said, the use of force under the law enforcement model could never be regarded as necessary unless it was clear that it was simply not possible to protect the prospective victim by apprehending the suspected perpetrator. The emblematic case justifying the use of force would be one where violence against the person to be protected was so near at hand or inevitable, and time so much of the essence, that the process of attempting to arrest the perpetrator would allow the threat to be realized. Others pointed out that under IHL, the use of lethal force was inherent to warfare and aimed to avoid or limit death, particularly of persons protected against direct attack, while acknowledging that the very nature of armed conflict was such that loss of life could not be avoided.

Another expert attempted to illustrate the differences between the two available models by referring to the issue of proportionality. He reminded his listeners that the aim of the IHL principle of proportionality was to limit incidental damage to protected persons and objects, while recognizing that an operation could be carried out even if such damage was likely, provided that it would not be excessive in relation to the concrete and direct military advantage anticipated. In contrast, the aim of the principle of proportionality under human rights law was to prevent harming everyone other than the person against whom force was being used; however, lethal force should not be used against even that person if there was another, non-lethal way of achieving the aim of the law enforcement operation.

While on the subject of the differences between the two models, one participant rejected the claim that the law enforcement model would provide rules and standards adequate for governing the quelling of threats stemming from insurgent groups in occupied territory. The expert submitted that the position taken by the European Court of Human Rights in the McCann and Isayeva cases, ${ }^{11}$ on the procedures for resorting to force, would not prove sufficient to allow the occupier to undertake efficient military operations. The expert claimed that States exerting effective control over a foreign territory would probably never consider embarking on military operations against the enemy in occupied territory under the law enforcement regime since it would always be more constraining in terms of preparation, execution and ex post facto assessment than IHL in relation to the targeting 
of individuals. The expert concluded by declaring that the human rights regime would certainly not provide all the answers in connection with the issue of using force in occupied territory.

The discussion ended with one expert declaring that the human rights regime suffered from one major flaw: its inapplicability to actions carried out by non-State actors. Therefore, he said, human rights law would fail to cover an important aspect of the use of force in occupied territory: the rules applicable to organized armed groups not belonging to the government of the occupied territory. A majority of the experts then said that human rights law would be relevant only for law enforcement purposes, but could not govern the hostilities involving occupying forces and non-State armed groups in the occupied territory.

\section{THE ROLE OF OCCUPATION LAW IN REGULATING LAW ENFORCEMENT ACTIVITIES}

During the discussions, some participants repeatedly asserted that occupation law provided no detailed rules for defining when and how the occupying power could use force during law enforcement activities. These experts were of the opinion that human rights law was the only relevant corpus juris for law enforcement operations carried out within the framework of the occupying power's obligation to restore and maintain public order and safety as reflected in Article 43 of the Hague Regulations.

Although it found some support among the experts, this view did not attract a consensus. In fact, other participants contended that it was not justified, in particular because it did not give enough credit to IHL. Four experts said that it was necessary to do away with the misconception that occupation law per se could not provide a valuable legal framework regulating the use of force in law enforcement operations, even though they understood that this misconception was based on the mistaken idea that the law enforcement model rested primarily on standards drawn from human rights law. These participants asserted that in fact, the law enforcement model applied in occupied territory, as a matter not of human rights law but of occupation law as stipulated in key provisions of the Hague Regulations and the Fourth Geneva Convention. In fact, they suggested, the combination of Article 43 of the Hague Regulations and Articles 27 and 64 of the Fourth Geneva Convention was the basis of the law enforcement role of the occupier and would constitute a fairly precise legal framework for regulating the use of force in occupied territory. However, while maintaining that the standards governing the use of force in law enforcement were based on occupation law, the four experts also recognized that these standards could be effectively supplemented by those stemming from human rights law. In this regard, some experts said that such an approach would illustrate perfectly the materialization of the concept of lex specialis compleat legi generali which consecrated the complementarity between IHL and human rights law. One participant said that IHL, occupation law in particular, would thus provide the main legal framework; human rights law would complement it with additional standards, such as precaution and proportionality, even though these were implied in Article 43 of the Hague Regulations. Such an approach to law enforcement in occupied territory would be more acceptable to States, insofar as situating law enforcement rules in IHL would permit them to get around difficulties related to the contentious issue of the extraterritorial application of human rights law. ${ }^{12}$

The discussions then turned to the interpretation and application of law enforcement standards in occupied territory. Some experts argued that these standards, stemming from human rights law or occupation law, should be interpreted and applied more liberally when the occupying forces resorted to force during police operations. Their position was based particularly on the fact that the application of law enforcement standards in situations of occupation would differ from that in peacetime. Therefore, these experts argued, standards on the use of force drawn from human rights law could not be transposed as such to police operations undertaken by the occupying power in occupied territory. In fact, the type of violence inherent in situations of occupation would justify adjusting the

However, one expert contested the idea that law enforcement activities in occupied territory would be governed by rules and standards based on occupation law. He challenged his opponents to find anything under occupation law that would endorse the use of force according to law enforcement standards. Since he considered occupation law to be silent on this issue, he felt that the human rights regime alone provided for appropriate and detailed rules pertaining to the use of force in police operations. Another participant added to these views by declaring that rules of engagement on the use of force during law enforcement were usually based on human rights law and not on IHL. 
precaution, proportionality and necessity standards in order to enable the occupying power to do what was required under occupation law: maintain public order and safety in a volatile and hostile environment.

These experts were of the opinion that the context of armed conflict in which the occupier was carrying out law enforcement activities permitted it greater latitude in the use of force than would have been the case in police operations carried out on its own territory. In addition, one expert pointed out, Article $27 \$ 4$ of the Fourth Geneva Convention (part of the law enforcement model based on occupation law) authorized the occupying power to take any security measures that "may be necessary" because of the occupation. The expert said that since the use of force during police operations would necessarily fall under this provision, the result would be substantial flexibility under the law enforcement model in situations of occupation. He suggested that security measures, including the use of force, within the meaning of Article $27 \$ 4$ of the Fourth Geneva Convention were based not on the standard of "strict" or "absolute necessity" required under human rights law, but on the more generous concept of military necessity underlying IHL.

This position was vigorously contested by other experts, who said that any use of force by the occupying power in situations other than the conduct of hostilities remained subject to the law enforcement standards of precaution, proportionality and necessity similar to those deriving from human rights law. Therefore, these participants concluded, the lawfulness of any deprivation of life unrelated to the conduct of hostilities in occupied territory had to be analysed in the light of the same criteria and conditions as in peacetime, ultimately establishing similarity of content between human rights law and IHL in relation to the use of force in law enforcement operations. The experts supporting the similarities in standards pointed out that the application of these standards in occupied territory would probably have results different from what one might expect in peacetime; they added that this was not because of an increased flexibility in the standards, but because the use of force in situations of occupation took place in circumstances that were self-evidently different.

Finally, the experts tried to identify the kinds of activity that would necessarily fall under the law enforcement model in occupied territory. Unfortunately, the participants were unable to reach a consensus on this issue, except in the case of criminal activities clearly unconnected to the occupation and the potential hostilities related to it. In fact, the experts only agreed that the law enforcement model would always prevail when the occupying forces were engaged in police operations aimed at enforcing the law against criminal acts not linked to the armed conflict.

\section{PART TWO: THE APPLICATION OF THE 'CONDUCT-OF-HOSTILITIES' MODEL IN OCCUPIED TERRITORY}

The foregoing discussions revealed agreement among the experts about the possibility that the law enforcement and 'conduct-of-hostilities' models could coexist and be applied simultaneously in occupied territory. Starting from that premise, the participants deemed it essential to identify the factors or criteria that would help to determine when an occupying power would be entitled to switch from the identified default model (e.g. law enforcement) to the 'conduct-of-hostilities' model in order to quell ongoing armed violence in occupied territory.

\section{A. WHEN DOES THE 'CONDUCT-OF-HOSTILITIES' MODEL COME INTO PLAY?}

The experts were convinced that the occupying power was not at liberty to treat every incident in occupied territory as necessarily falling under the 'conduct-of-hostilities' model. In this regard, they asserted that occupation, per se, would not justify the use of the 'conduct-of-hostilities' model without clear proof of organized armed violence - for instance, the continuation of active hostilities linked to the original international armed conflict from which the occupation derived or the resurgence of hostile military operations by organized armed groups more or less connected to the occupied State. The experts thus defined a necessary condition: there must be a verifiable prerequisite for the application of the more permissible 'conduct-of-hostilities' model in occupied territory. They 
were of the opinion that active hostilities must be observable in occupied territory in order for the IHL rules on the conduct of hostilities to become applicable. Without the sort of hostilities that characterize active armed conflict, the occupying power would not be entitled to resort to the 'conduct-of-hostilities' model and its substantive rules. Therefore, the experts agreed, it was necessary to determine when active hostilities could be said to occur in occupied territory.

The experts underlined the importance of conducting an objective assessment of the situation in order to identify the model applicable. They pointed out that the occupying power would not be legally entitled to say that it was conducting a military operation regulated by the laws governing the conduct of hostilities if the situation in question proved to be, because of the nature of those involved and/or the specific circumstances, one of law enforcement. The occupying power would not be authorized to turn a certain action into a military operation - and thus apply the 'conductof-hostilities' model - simply by unilaterally using means and methods of warfare where they are not required by the prevailing circumstances.

One expert said that the occupying forces should be confronted with armed violence of a certain intensity in order to be able to resort to the 'conduct-of-hostilities' model. Others proposed, for the purposes of determining when the 'conduct-of-hostilities' model would apply, that a distinction be made between armed violence linked to the original international armed conflict and that emanating from organized armed groups not affiliated with the occupied State.

\section{The continuation/resumption of fighting between the occupying power} and the occupied State's armed forces and affiliated armed groups

With regard to armed violence connected to the original international armed conflict that led to the occupation, some experts said that the occupying power would be entitled to use the 'conduct-of-hostilities' model when military force was used against the armed forces of the occupied State, affiliated militias or other resistance movements fulfilling the criteria of Article 4(A)(2) of the Third Geneva Convention. The experts held nonetheless that the law governing the conduct of hostilities would apply only if active hostilities persisted or had resumed within the framework of the original international armed conflict. As they emphasized, the threshold for determining the existence of an international armed conflict had always been considered very low under Article 2 common to the four Geneva Conventions. Any degree of armed violence involving the occupying power on one side, and the armed forces and other organized armed groups belonging to the occupied State on the other, would thus justify resort to the IHL rules governing the conduct of hostilities.

Some experts remarked that members of the defeated armed forces and organized armed groups in the occupied territory might decide at some point to take up arms and resume hostilities. Should this happen, the occupying power would be able to use force against them under the 'conduct-of-hostilities' model without waiting for a certain threshold of intensity in the fighting to be reached. In fact, the experts opined, the international aspect of the hostilities and their connection to the original international armed conflict would not require any threshold of intensity to be reached in order to trigger the application of the law governing hostilities. The occupying power would thus be entitled to react immediately and use the 'conduct-of-hostilities' model against the armed forces of the occupied State and the organized armed groups belonging to that State as soon as they took up the fight again.

In connection with the original international armed conflict, two experts said that the 'conduct-of-hostilities' model had a limited temporal scope of application insofar as enemy armed forces could not be targeted under it once they had been completely defeated and/ or effectively laid down their arms. In others words, the occupying power would be entitled to resort to the 'conduct-of-hostilities' model against the armed forces of the occupied State and affiliated organized armed groups until those combatants laid down their arms or showed a lasting disengagement from the permanent combat function they exercised in such organized armed groups. Once they have surrendered completely, the legal status of the armed forces of the occupied territory under IHL (e.g. combatants) would no longer be a sufficient condition justifying per se the use of force against them. Resumption of hostilities by the armed forces of the occupied State and other affiliated groups would nonetheless 
revive application of the 'conduct-of-hostilities' model. Thus, one expert contended, the legal status of the individuals subject to the use of force under the 'conduct-of-hostilities' model should be complemented by the resort to armed violence in which the concerned individuals or groups of individuals are involved.

\section{Fighting between the occupying power and organized armed groups}

Even as they acknowledged the importance of establishing when the 'conduct-of-hostilities' model should apply to the initial international armed conflict occurring in the occupied territory, some experts pointed out that hostilities and other acts of violence directed towards the occupying power would usually emanate from organized armed groups not formally "belonging to" the occupied State within the meaning of IHL. ${ }^{13}$ As a result, the experts agreed to discuss the conditions under which the law governing the conduct of hostilities would become the legal framework of reference in such circumstances.

The experts felt that IHL's response, when such armed groups not belonging to the occupied State carried out hostile activities in occupied territory, was not clear; and that it was necessary to clarify when IHL rules on the conduct of hostilities would begin to apply. In this regard, the experts said, the threshold for determining the existence of a non-international armed conflict within the meaning of Article 3 common to the four Geneva Conventions (common Article 3) provided a very workable test. The experts stressed that any use of force in occupied territory against organized armed groups not "belonging to" the occupied State within the meaning of IHL could fall under the 'conduct-of-hostilities' model only after the criteria of a non-international armed conflict had been fulfilled. The 'conduct-of-hostilities' model would therefore apply only when the groups opposed to the occupying power displayed a form of organization enabling them to conduct concerted military operations and when the violence committed by them reached a certain level of intensity. The use of these criteria was justified by the fact that this kind of confrontation would constitute a "new" armed conflict unconnected to the one that led to the occupation, since the parties challenging the occupying power's effective control would not be identical even if they claimed, as they often do, to fight on behalf or in support of the occupied State.

Some experts argued that the criteria for non-international armed conflict to be applied in such a case could be drawn from or inspired by the jurisprudence of the International Criminal Tribunal for the former Yugoslavia (ICTY). ${ }^{14}$ In fact, decisions handed down by the ICTY established, according to the experts, an appropriate frame of reference for the various criteria defining a non-international armed conflict within the meaning of common Article $3 .{ }^{15}$ The ICTY, while acknowledging that the intensity of the fighting and the participation of organized armed groups were indispensable conditions, defined what could constitute probative indications that those requirements had been met. ${ }^{16}$ The experts agreed that these criteria would be particularly helpful in determining when the occupying power would be authorized to resort to force against organized armed groups not belonging to the occupied State under the 'conduct-of-hostilities' model.

The experts then addressed some of the consequences of using the conditions triggering non-international armed conflict for determining when the occupying power could use force under the 'conduct-of-hostilities' model against organized armed groups not belonging to the occupied State. Some experts suggested that the occupying power could never initiate

13 For a discussion of the concept of "belonging to" a party to the conflict, see infra.

14 See, in particular, ICTY, Prosecutor v. Limaj, Case No. IT-03-66-T, Judgment (Trial Chamber), 30 November 2005; Prosecutor v. Haradinaj, Case No. IT-04-84-T, Judgment (Trial Chamber), 3 April 2008; Prosecutor v. Boskoski, Case No. IT-04-82, Judgment (Trial Chamber), 10 July 2008.

15 It should be noted that the experts unanimously agreed that only the criteria derived from common Article 3 were relevant. One expert in particular stressed that the criteria proposed in Article 1 of Additional Protocol II were not relevant for assessing when the 'conduct-of-hostilities' model would apply in occupied territory.

16 The experts pointed out that the ICTY had identified the following elements for the "intensity" criterion: the number, duration and intensity of individual confrontations; the types of weapons and other military equipment used; the number and calibre of munitions fired; the number of persons and types of forces taking part in the fighting; the number of casualties; the extent of material destruction; the number of civilians fleeing combat zones, etc. To assess the level of organization of the parties to the conflict, the experts said, the Trial Chamber (in the cases mentioned in footnote 14) proposed relying on indicative factors such as the existence of a headquarters; the fact that the group controls a certain territory; the group's access to weapons, other military equipment, recruits and military training; its ability to plan, coordinate and carry out military operations, including troop movements and logistics; and its ability to define a unified military strategy and use military tactics, etc. 
a state of armed conflict against such groups. Instead, it would have to wait for the groups to organize themselves and start hostilities that reach the prescribed degree of intensity; only then could the occupying power use the law governing the conduct of hostilities against these armed groups. Any use of force under the 'conduct-of-hostilities' model that is made before the realization of these two essential conditions would therefore constitute an unlawful attack against civilians unless they directly participate in the ongoing hostilities occurring within the framework of the original international armed conflict. In other words, to justify a response based on the law governing the conduct of hostilities, active hostilities should be the result of military operations instigated by "independent" organized armed groups (that is, groups not linked to the occupied State) that challenge the occupying power; these operations should amount to a non-international armed conflict. In fact, some experts claimed that only this level of threat would justify the use of military force under the 'conduct-of-hostilities' model. ${ }^{17}$

Some participants contested this position, stressing that it would not only lack a solid basis under IHL but would also be completely unrealistic. Others agreed that it would ultimately introduce an artificial distinction between the violence occurring in the international armed conflict linked to the occupation and that taking place in the non-international conflict. In fact, they said, an occupying power would never sit idly by and wait until the organized armed groups' attacks reached the threshold of intensity required for a non-international armed conflict before dealing, under the 'conduct-of-hostilities' model, with such a threat. In this regard, some experts said that the criteria for a non-international armed conflict would be too strict to constitute an appropriate benchmark on which to decide whether the 'conduct-of-hostilities' model applied to the situation at hand.

One expert suggested a compromise between these two positions, by adjusting the criteria for non-international armed conflict derived from common Article 3. He proposed that first, the criterion pertaining to the degree of organization of the armed group should not be changed; then, that the criterion of intensity could be lowered when the armed confrontation occurred between occupying forces and independent armed groups. He made the particular point that such adjustments could be justified by the pre-existence of a state of belligerency associated with the already established occupation. Since the armed confrontation opposing the occupying power to independent armed groups could not be completely unrelated to the occupation - the latter having created the conditions for the existence of the former - one could argue that the requirement of intensity could be less strict than that applicable to an entirely new armed conflict. The expert, joined by other participants, contended that the occupying forces could resort to the 'conduct-of-hostilities' model once such groups were sufficiently organized to carry out concerted military operations and able to strike at short notice.

However, two experts cautioned against tinkering with the traditional criteria for determining the existence of a non-international armed conflict. They were particularly concerned about the introduction of another threshold for non-international armed conflict specifically for occupation. Adding another threshold, they said, would make it even more difficult to identify the legal framework applicable to hostilities in occupied territory. They also said that concerted attacks conducted by organized groups would still be necessary in order to substantiate the degree of organization required by common Article 3. Thus, the requirement of organization would be realized only through military operations against the occupying power. These experts asserted that the criterion of intensity should not be lowered or adjusted for the purposes of occupation. They felt that the law enforcement model offered an adequate and efficient legal framework, one that made it possible to counter the threat posed by armed groups in the process of organizing themselves and not yet involved in concerted acts of violence. The experts stressed the need to do away with the misconception that only the 'conduct-of-hostilities' model would permit resorting to lethal force in such circumstances.

The experts pointed out the importance of the occupying power's inability under the law to create on its own the conditions for directly applying the 'conduct-of-hostilities' model when resorting to force against organized armed groups not belonging to the occupied State. See supra. 
Two other participants, while agreeing that it was permissible to authorize the use of lethal force as a preventive measure, remarked that the planning and methods used under the law enforcement model would not necessarily be adapted for quelling and eradicating the threats emanating from organized armed groups, or armed groups in the process of organizing themselves, operating in a context of belligerency. These experts and some others were of the opinion that threats emanating from such armed groups could be dealt with only by applying the IHL rules on the conduct of hostilities.

Not having reached consensus on this point, the experts moved on to discuss the geographical scope of application of the 'conduct-of-hostilities' model in occupied territory. Most of them felt that the model should not be restricted to the battlefield or where hostilities flared up, but should apply throughout the occupied territory when force was used against the armed forces of the occupied State or against organized armed groups, regardless of whether they were affiliated to the occupied State. In fact, the experts argued, force may be used against these persons under the 'conduct-of-hostilities' model, irrespective of their location in the occupied territory. It should be noted that some of the experts supporting this position stressed that such use of force could, depending on the circumstances, be restrained by military necessity and/or the principle of humanity.

Two experts disputed this broad application of the 'conduct-of-hostilities' model. They said that its application should be limited to the place where the attack occurred and only for the duration of the incident, because any other interpretation would call into question the choice of the law enforcement regime as the default model in occupied territory.

\section{B. THE LEGAL CLASSIFICATION OF HOSTILITIES ON OCCUPIED TERRITORY}

Having discussed in detail the conditions triggering the application of the 'conduct-of-hostilities' model in occupied territory, the experts turned their attention to a related question: How should armed confrontations persisting or developing within the framework of an occupation be classified legally?

The experts dwelt on various scenarios likely to develop in situations of occupation; they distinguished between two kinds of armed confrontation: those connected to the original international armed conflict that led to the occupation and those related to a "new" non-international armed conflict emerging alongside the occupation. The experts were almost unanimous that, for the purposes of IHL, a non-international armed conflict could well occur in conjunction with an occupation. ${ }^{18}$ As a consequence of this assessment, the experts opted for a fragmented approach to relationships between belligerents in situations of occupation and confirmed the possibility of a double legal classification. The occupation per se and the armed confrontation between the occupying forces and the armed forces of the occupied State and affiliated armed groups would constitute an international armed conflict; and the fighting between the occupying power and independent organized armed groups would amount to non-international armed conflict.

Determining what, in this context, constituted the international armed conflict appeared quite easy and the experts quickly reached a consensus on the main aspects of the question. They were unanimous that the hostilities pitting the occupying forces against the armed forces of the occupied State would clearly fall under the definition of international armed conflict. The experts also agreed that armed violence in occupied territory involving the occupying power and militias, volunteers corps and other organized resistance movements "belonging to" the occupied State and fulfilling the criteria set out in Article 4(A)(2) of the Third Geneva Convention should also be construed as an international armed conflict. ${ }^{19}$

The possibility of a non-international armed conflict existing alongside an occupation prompted more discussion.

8 Only one expert disputed the possibility of a non-international armed conflict taking place within the context of occupation. See discussion infra on page 30 .

19 However, one expert pointed out that in present-day occupation, organized armed groups that claimed to fight on behalf of the occupied State rarely met the necessary criteria, thus creating some doubt about how their involvement in hostilities against the occupying forces should be classified legally. 
First, some experts argued that armed violence pitting the occupying power against organized armed groups not connected with the occupied State would be non-international in character because it involved a State (i.e. the occupying power) and a non-State actor. Their arguments were based on the fact that an international armed conflict could exist only between two or more entities having an international legal personality for the purposes of public international law. The experts said that regarded from this perspective, the law governing non-international armed conflict would become a residual body of law applicable to any armed conflict that was not a confrontation between States but one between a State or a coalition of States and one or several non-State actors. In the latter case, the armed confrontation should be characterized as a non-international conflict provided it meets IHL requirements implied by common Article 3. Consequently, the experts argued, any armed conflict opposing the occupying power to non-State actors not belonging to the occupied State should be considered non-international.

Second, the experts dwelt on the meaning and consequences, legally, of the involvement of organized armed groups who are fighting on behalf of the occupied State (or claiming to do so), or beside its armed forces, against the occupying power. The experts considered the nature of the relationship between these organized armed groups and the government of the occupied territory to be of the utmost importance for determining the legal classification of the armed violence opposing these groups to the occupying power.

The discussions focused on the interpretation of the term "belonging to" - in the phrase, belonging to a party to the conflict - as formulated in Article 4(A)(2) of the Third Geneva Convention. In fact, clarifying this notion was deemed essential for the purposes of legal classification because if it is impossible to ascertain whether these organized armed groups "belonged to" the occupied State, they should be regarded as non-State actors whose involvement in the hostilities taking place in occupied territory could be analysed only in light of the paradigm of non-international armed conflict.

For some experts, the term "belonging to" implied a requirement of control, as the rationale of Article 4 of the Third Geneva Convention was that States should be legally responsible for the conduct of the irregular forces they sponsor. In others words, the experts said, determining whether organized armed groups belonged to the occupied State hinged on whether their acts could be attributed to the latter. Should the acts of organized armed groups be attributable to the occupied State for the purposes of public international law, they would be considered to "belong to" that State and would consequently be involved in the international part of the armed conflict.

In this regard, and since IHL did not provide criteria regarding imputability specific to this body of law, some experts suggested that IHL be supplemented by others rules of public international law. They proposed relying on the criteria established by general rules on State responsibility, as reflected in the International Law Commission's Articles on Responsibility of States for Internationally Wrongful Acts. ${ }^{20}$ The experts drew attention to the role played by Article 8, which establishes the responsibility of a State for acts committed by an individual or a group of individuals, whether on the basis of instructions given to them or under the direction or control exerted by that State over them. Should these criteria be fulfilled within the framework of occupation, the individuals or organized armed groups confronting the occupying forces would be recognized as acting as de facto agents of the occupied State and therefore involved in the international armed conflict against the occupying power.

In relation to the criterion of control, some experts mentioned - in addition to the International Law Commission's Articles on State Responsibility - the importance of the ICTY's jurisprudence, particularly the Tadic case, which conceived the "overall control" test for the purposes of classifying situations under IHL. According to this test, it would be sufficient for organized armed groups to be under the overall control of the occupied State for their acts to be attributed to that State. Following the ICTY's jurisprudence, the degree of control required by international law would be deemed to exist when the occupied State played a role in organizing, coordinating or planning the military action of the organized armed group in question. The experts also pointed out that acts committed

20 Articles on Responsibility of States for Internationally Wrongful Acts, adopted by the International Law Commission at its fifty-third session (2001); extract from the Report of the International Law Commission on the work of its fifty-third session, Official Records of the General Assembly, Fifty-sixth Session, Supplement No. 10 (A/56/10), chp.IV.E.1. 
by the group or its members would be regarded as those of de facto organs of the occupied State, even in the absence of any specific instructions from the latter on the commission of each of those acts. In this regard, one expert - joined by several others - drew the conclusion that organized armed groups whose actions could be attributed to the occupied State for the purposes of the law governing State responsibility should be deemed to "belong to" the occupied State and be assimilated to the latter's armed forces.

However, four experts dissented: they were opposed to establishing the concept of control as the criterion for determining if organized armed groups belonged to the occupied State. They said that this criterion, derived from the international law of State responsibility, would be too rigorous for the purposes of determining whether an organized armed group belonged to the occupied State. In fact, one participant said, under the effective/overall control test, almost none of the armed resistance groups during World War II would have fulfilled the requirements of Article 4(A)(2) of the Third Geneva Convention and would have qualified as a party to the international armed conflict raging at the time.

One of these experts suggested softening the test for the purposes of IHL. According to his proposal, the concept of "belonging to" would require only a de facto relationship between the organized armed group and the occupied State, which could be established by a formal declaration, through tacit agreement or even in light of conclusive behaviour making clear for which party the group would fight. Therefore, the expert said, in practice and within the meaning of IHL, in order for an organized armed group to belong to the occupied State, it was essential that it conducted hostilities on behalf of and with the agreement of that party. ${ }^{21}$ In this way, the test for identifying whether an organized armed group belonged to the occupied State could be made looser for the purposes of IHL.

Another expert doubted that one could speak of a new and independent non-international armed conflict when an occupied State had collapsed and organized armed groups claimed to be fighting for the liberation of their land. Since the original international armed conflict and the resulting occupation would necessarily have created the conditions for the occupied government's breakdown and the appearance of armed resistance groups fighting on behalf of the occupied State, ${ }^{22}$ this expert regarded the armed confrontation between those resistance groups and the occupying forces as a continuation of the original international armed conflict. He saw no need to legally reclassify the situation in question and advised against hastily concluding that organized armed groups would not meet the "belonging to" criterion, which, he felt, should be interpreted in quite a loose way.

One expert also pointed out that the criterion of control was not the only legal option for attributing the conduct of organized armed groups to the occupied State. He drew attention to the relevance of Article 9 of the International Law Commission's Articles, which attributed a non-State actor's conduct to the State in which that actor was exercising elements of government authority "in the absence or default of the official authorities." ${ }^{23}$ The expert felt that this warranted discussion. This provision, which took effect only in exceptional circumstances, such as during revolution and armed conflict - and also during military occupation (in particular when the usual forms of authority had been dissolved, were disintegrating, or had been suppressed) - was deemed to owe something to the old idea of the levée en masse, citizens rising up to defend themselves and the nation in the absence of regular forces. In other words, the expert held, invoking the International Law Commission's commentaries to the Articles, the test alluded to in Article 9 of the Commission's Articles implied a form of agency by necessity.

Thus, the expert contended, if the administration (broadly defined) of the occupied State had fallen apart and there was no authority exerting any governmental functions in its stead, a spontaneous

21 One expert asserted that the fighting between organized armed groups and the occupying forces would still be a continuation of the original international armed conflict when those entities could be associated in one way or another with the occupied State. Another expert argued that the claim to be fighting on behalf of the occupied State alone, when not denied by the occupied State, would suffice to fulfil the "belonging to" criterion.

22 One expert felt that, in case the occupied State has collapsed, the armed confrontation opposing the occupying forces to organized armed groups calling themselves the armed forces of the occupied territory could be regarded as international only if such groups are internationally recognized as the legitimate representatives of the failed State.

23 This provision from the International Law Commission's Articles on State Responsibility reads as follows:

"A conduct of a person or group of persons shall be considered an act of a State under international law if the person or group of persons is in fact exercising elements of the governmental authority in the absence or default of the official authorities and in circumstances such as to call for the exercise of those elements of authority." 
resistance movement could fulfil the requirement of belonging to this State, at least until there was time and opportunity to organize a government or similar authority that would assume responsibility for the armed struggle.

The expert also emphasized that Article 9 did not require the occupied State to formally delegate authority to the organized armed group; it appeared to most closely reflect the notion of tacit agreement, cited previously by another expert as being sufficient to establish a State/resistance link under Article 4(A)(2) of the Third Geneva Convention in order to classify the conflict opposing the occupying power to organized armed groups as international.

One expert disputed the possibility that an armed confrontation erupting alongside the occupation could be considered non-international. He pointed out that 'occupation' and 'non-international armed conflict' were mutually exclusive concepts. He drew attention to the intimate legal relationship between occupation and the notion of international armed conflict, the former being a trigger for the latter. Consequently, the expert declared, any armed confrontation, irrespective of the parties involved, would be "internationalized" by the mere fact of having developed within the framework of occupation.

The lone dissenting opinion notwithstanding, the experts reiterated their conclusion: organized armed groups linked to the occupied State, either through the overall control exerted by the latter or as regular members of its armed forces, would be involved in an international armed conflict when fighting the occupying forces; and a confrontation between an occupying power and organized armed groups not belonging to the occupied State should be viewed as detached from the original international armed conflict and construed as a new armed conflict of a non-international character, provided the IHL requirements of organization and intensity are met.

Having discussed the legal nature of armed confrontations in occupied territory, the experts briefly addressed the consequences thereof.

One expert stressed the importance, for the issue of targeting, of the legal classification of hostilities taking place in occupied territory. He held that those fighting for organized armed groups not belonging to the occupied State and opposed to the occupying power would lose their protection from direct attacks on the basis of their membership of such groups only when the group became party to the new non-international conflict. Until the threshold of non-international conflict was reached, these individuals may be targeted by the occupying power only when they take direct part in the hostilities. In other words, the expert argued, in the absence of non-international conflict, fighters not affiliated to the armed forces of the occupied State would benefit from the so-called "revolving door theory" and could be targeted only very briefly - during their preparation for, deployment, execution of and return from hostile acts against the occupying power.

Another expert pointed out that, as a direct consequence of the dichotomy established between international and non-international armed conflict in occupied territory, the occupying forces would not be entitled to launch preventive military operations under the 'conduct-of-hostilities' model against organized armed groups not belonging to the occupied State. In fact, the expert said, as discussed previously, the occupying power would have to wait for the criteria of organization and intensity required by IHL to be met before establishing the necessary situation of non-international armed conflict. Consequently, before the fulfilment of those legal conditions, force could be used against organized groups not belonging to the occupied State only under the law enforcement model, unless these groups take a direct part in the hostilities occurring within the context of the international armed conflict.

One of the experts then shed some light on the consequences, for the legal status of captured persons, of the legal classification of hostilities in occupied territory. He stressed that 'double classification' (i.e. non-international armed conflict alongside the occupation) could lead to a situation in which fighters captured within the framework of the non-international armed conflict could also lay claim to protection under the Fourth Geneva Convention on the basis of being covered by the notion of "protected persons" set out in its Article 4. The expert argued that in such a situation, where the law governing international armed conflict overlaps with that governing noninternational armed conflict, as far as members of an armed group with a continuous fighting 
function are concerned, IHL provisions related to non-international conflict should prevail as a matter of lex specialis. As a result, such fighters captured within the framework of the noninternational armed conflict by the occupying power would benefit only from the protection of common Article 3. This was contested by other experts. The occupation itself created the conditions for the non-international conflict, the experts said, and the members of the organized armed groups not belonging to the occupied State would probably fulfil the conditions set out in Article 4 of the Fourth Geneva Convention. Given this, the experts said, the members of those groups could still benefit from the protection of the Fourth Geneva Convention.

Two other experts pointed out that another important reason for classifying as a non-international armed conflict a confrontation opposing the occupying forces to organized armed groups not belonging to the occupied State was the groups' capacity to comply with the relevant IHL rules. They argued that the law governing non-international armed conflict, particularly because of its limited number of provisions, was better suited to dealing with such situations as it was specifically designed for dealing with armed violence involving non-State actors. In fact, the limited resources of these groups, combined with the absence of the apparatus necessary to implement the law of international armed conflict, would limit their ability to comply with the full set of norms applicable in international armed conflict. Since IHL efficiency was notably based on its effectiveness and the ability of the parties to respect its provisions, choosing the law governing non-international armed conflict as the legal framework applicable to the fighting between the occupying power and organized armed groups was deemed fitting and practical.

\section{DETERMINING THE LEGAL FRAMEWORK GOVERNING THE USE OF FORCE IN “GREY AREAS"}

The last subject considered by the experts was the legal framework applicable to operations that were both a police operation against an individual violating the laws in force in occupied territory (including measures promulgated by the occupying power) and a military operation against a legitimate military target under IHL. The participants were clearly divided on this question. Some claimed that the law enforcement model would prevail in such grey areas; others were clearly inclined to promote the application of the 'conduct-of-hostilities' model as a matter of law. In the end, the majority of experts favoured the prevalence of the 'conduct-of-hostilities' model in such circumstances.

One argument put forward in support of this position was that when the occupying forces were dealing with enemies who had not yet been subdued they would generally interpret any use of force against opposing parties on the basis of the law governing the conduct of hostilities and certainly not on that of the law enforcement model. This was explained largely by the fact that the occupying power would be unlikely to address threats as individualized criminal activities, but would take a much broader approach based on the wider threats posed to its forces. Given that these wider threats would usually originate in organized armed groups, the experts declared, the 'conduct-of-hostilities' model would establish itself as the only one that was relevant in such circumstances. In fact, detecting and dealing with such threats would likely be beyond the occupying power's law enforcement abilities, which would point towards the use of the 'conduct-of-hostilities' model. Therefore, any preparation, planning and execution of military operations in occupied territory designed to counter these wider threats would be approached solely from the IHL and 'conduct-of-hostilities' perspective. In this regard, some experts drew attention to the importance of the ICRC's Interpretive Guidance on the Notion of Direct Participation in Hostilities under IHL for identifying individuals and organized armed groups constituting such wider threats and justifying resort to the 'conduct-of-hostilities' model. ${ }^{24}$

One expert pointed out that the law enforcement and 'conduct-of-hostilities' models could overlap when the occupying power carried out preventive action aimed at countering the ongoing constitution of armed groups. In such instances, the degree of organization reached by hostile individuals posing a threat to the occupier would have a significant bearing on identifying the model applicable. Therefore, force could not always be used within the framework of the law governing the conduct of hostilities when the occupying power was dealing with armed groups not yet fully constituted. Some experts advocated a case-by-case approach in such circumstances; they also stressed the importance 
of gathering intelligence on such groups in order to decide whether the threats emanating from them could be dealt with under the law enforcement model or whether it required the more permissible legal framework provided by the 'conduct-of-hostilities' model. Eventually, the experts agreed that the prevailing facts and the nature of the context would determine the model to be applied to the use of force in occupied territory; they said that this would be even truer in situations of overlap. Therefore, the circumstances in which the threats against the occupying power arose would also be decisive in identifying the model applicable.

However, two experts challenged the prevalence of the 'conduct-of-hostilities' model in situations of overlap. They claimed that there was no legal basis under IHL for treating the law governing the conduct of hostilities as a matter of lex specialis in such circumstances. According to these experts, the provisions of human rights law governing law enforcement operations would provide a sufficiently flexible framework as well as practical solutions for coping with the threats posed by individuals who were simultaneously criminals under the legislation applicable in occupied territory and legitimate targets within the meaning of the law governing the conduct of hostilities. A particular contention of theirs was that human rights law was flexible enough for its norms to be construed within the context of the belligerency inherent to occupation and thus to justify resorting to force based on more relaxed conditions than in peacetime. Consequently, these participants argued, the law enforcement model was more suitable for dealing with this situation of overlap, as it perfectly fitted the reactive mode under which occupying forces would often be operating in occupied territory. The use of force in this reactive approach would be based mainly on the concept of escalation of force, which also characterized the law enforcement regime.

Two other experts proposed a different method for determining the model applicable in situations of overlap. They said that the degree of control the occupying power had over the circumstances surrounding a military operation, as well as its control over the place where that operation would take place, could be useful criteria for determining whether the rules pertaining to law enforcement or those governing the conduct of hostilities would apply as a matter of lex specialis. Control over the circumstances of the operation and over the areas in question would trigger application of the law enforcement model. Therefore, when the occupying forces conducting a specific operation are not excessively concerned about having to deal with other members of the organized armed group, meaning that additional military means would not be required to make the operation a success, the law enforcement model would become applicable. On the other hand, when the occupying forces expect to be militarily challenged by fighters from organized armed groups, then the operation should be carried out within the framework of the 'conduct-of-hostilities' model. This double layer of control (control over the operation within the broader concept of effective control over the occupied territory) was well received by the other experts, except one who challenged the practicality of the proposal. Thus, level of control within the broader concept of effective control over the occupied territory was accepted as an important criterion in situations of overlap and regarded as a workable option for determining the model applicable.

Some experts pointed out that once applicable, the 'conduct-of-hostilities' model would not necessarily sanction a "shoot to kill" policy against persons who were both criminals according to the legislation in place in occupied territory and legitimate targets under IHL. In this regard, some experts asserted that the force to be used against them should never exceed that which was necessary to accomplish the legitimate military objective of achieving their complete submission. It was therefore argued that the principles of military necessity and humanity would play a restraining function with regard to the use of force, in particular when the occupying forces controlled the area and the circumstances in which its military operations were conducted. Another expert remarked that such restraints would become decisive when the occupying forces operated against selected individuals in situations similar to peacetime policing. It follows, therefore, that in areas over which the occupying power had less control or where the insurgents were able to conduct well-structured operations, the principles of military necessity and humanity would be less likely to restrict the use of force against legitimate targets beyond what is already required by the specific provisions of IHL. However, a few experts challenged these views on the restrictive role played by the principles of military necessity and humanity on the grounds that it would not reflect lex lata.

As the meeting drew to a close, the experts took up the question of undercover operations. Some of them held that undercover operations exemplified the intricacies of situations of overlap; they 
pointed out that occupying powers often had recourse to such operations in order to deal with persons whose conduct was covered by both the law enforcement and the 'conduct-of-hostilities' models.

One expert asserted that "undercover operations" was not a concept used under IHL and that carrying out such operations, particularly in occupied territory, was not illegal per se. In fact, he said, IHL contained no specific references to undercover operations; but it also did not specifically forbid the occupying power from resorting to undercover operations in occupied territory. However, attention was drawn to the fact that such operations raised an important issue: the legality of occupying forces' wearing civilian dress during their military operations. It was pointed out that even though IHL did not impose on the occupying forces an explicit duty to wear uniforms at all times, it obliged them to distinguish themselves from the civilian population during an attack and during the military operations preparatory to an attack. Deliberately not wearing uniforms could thus amount to feigning civilian status, which, when done in order to kill, injure or capture an adversary, would constitute perfidy, prohibited under IHL. The experts emphasized the importance of classifying the nature of the operations during which force was resorted to and of determining whether such undercover operations were conducted under the law enforcement or the 'conduct-of-hostilities' model.

Another expert observed that undercover operations had too often been associated with the prohibitions against perfidy and treachery. Consequently, some people were too ready to conclude that undercover operations in occupied territory were unlawful, a position that had no basis under IHL. However, it was argued that labelling the occupying power's activities as undercover operations said very little about whether they conformed to IHL. Rather, it was necessary to examine the circumstances in which these operations take place together with the specific legal standards pertaining to them. Thus, merely referring to something as an undercover operation would not obviate the need to examine the nature and purpose of the acts carried out and the attendant circumstances.

The experts agreed that it could be persuasively argued that activities that qualified as law enforcement - such as 'search-and-arrest' operations - would not, for the purposes of the 'conduct-of-hostilities' model, qualify as military operations, during which combatants were obliged to distinguish themselves. Conducting law enforcement operations in civilian dress thus did not constitute perfidy, as the arrest of a civilian in occupied territory was not tantamount to capturing an enemy. Attention was drawn to the fact that police officers often wear civilian clothes when engaged in activities such as intelligence gathering and 'search-and-arrest' operations. Therefore, there was a good case for arguing that when carrying out such law enforcement missions in occupied territory, the occupying forces could do so in civilian dress, without being required to distinguish themselves and without committing perfidy while doing so.

Some experts also contended that, to be credible, claims that undercover operations were unlawful should be placed within a broad analytical framework governing the relationship between the 'conduct-of-hostilities' and law enforcement models. They considered this to be the crux of the issue, since undercover operations lay at the heart of the separation between the law enforcement and 'conduct-of-hostilities' models and could result not only in the arrest of a civilian in breach of the occupier's legislation in occupied territory, but also in the capture of an enemy.

Faced with this dilemma, one expert praised the flexibility offered by law enforcement with regard to undercover operations. He emphasized that this model would better equip the occupying power to deal with threats posed in occupied territory, as members of its forces would not be obliged to wear uniforms and would have recourse to means and methods otherwise prohibited in the course of military operations connected to the conduct of hostilities. Another participant proposed a less stringent dichotomy between the law enforcement and 'conduct-of-hostilities' models in relation to undercover operations, one that would allow the occupying power to make use of them even when conducting operations connected to the conduct of hostilities. This was contested by other experts. They declared that the current legal framework governing undercover operations remained necessary to prevent the adoption of a pick-and-choose approach, which could lead to a loosening of the conditions under which lethal force could be used, and thus ultimately to a diminution of the protection granted by IHL to the civilian population of the occupied territory. 


\section{THE USE OF FORCE IN OCCUPIED TERRITORY: THE APPLICABLE LEGAL FRAMEWORK BACKGROUND DOCUMENT BY PROF. ANDREAS PAULUS}

\section{INTRODUCTION: THE USE OF FORCE IN OCCUPIED TERRITORY AND THE OVERLAP BETWEEN LEGAL REGIMES}

Fragmentation is one of the most popular words in contemporary international law to describe the relationship between different legal regimes. However, in many respects, the extent of the problem seems to be smaller than often suggested. ${ }^{1}$ As a report of the International Law Commission has shown, most problems of fragmentation can be solved by the application of traditional interpretative tools, from the lex specialis rule to conflict-of-law rules (Article 103, United Nations Charter), and, eventually, hierarchical rules such as jus cogens. ${ }^{2}$ In general, the problem is not so different from other contradictions within a single legal regime that courts and tribunals cope with every day. In the most difficult case, however, namely the existence of two clearly conflicting obligations, the only remaining solution is accommodation and respect for other legal regimes, which minimizes the confrontation as far as possible.

The use of force in occupied territories is one of the areas in which different legal regimes are vying for application, and there is no guarantee that they will always arrive at identical results. The most typical example is probably the rule of proportionality that applies, under the rules on the conduct of hostilities, only to civilians (and civilian objects) not taking part in hostilities and only prohibits the use of excessive force (see Article 51, para. 5 (b), Additional Protocol I), whereas, in human rights law, the direct target of an attack is also protected by the right to life that requires the application of a strict test of proportionality. ${ }^{3}$ The matter becomes even more complicated in view of the relevant rules of the jus ad bellum, as well as by the separation in international humanitarian law of the rules covering civilians not taking part in hostilities, occupation in particular, as contained in the Hague Regulations and in the Fourth Geneva Convention, from the rules on the conduct of hostilities codified in the two Protocols of 8 June 1977 additional to the Geneva Conventions.

This clash of legal regimes is not only a glass bead game, to cite a famous novel by the German-Swiss writer Hermann Hesse, but has a very practical impact on the rules applicable to occupied territory. To give an example that has galvanized international discussion, the practice of targeted killings in the occupied Palestinian territories has led the Israeli Supreme Court to a judgment combining elements from humanitarian law, human rights law, and Israeli administrative law, ${ }^{4}$ whereas the report of the United Nations Fact Finding Mission on the Gaza conflict has based its legal findings alternatively on international humanitarian law and human rights law. ${ }^{5}$

The following remarks do not pretend to conclusively deal with all the questions involved. What I will do instead is look at the normative - and, admittedly, more general and theoretical - question of the applicability of normative regimes and their eventual overlap. As a result, I conclude that each normative regime needs to be looked at separately, and that it may turn out impossible to always find

Similarly, B. Simma, "Universality of international law from the perspective of a practitioner," European Journal of International Law, 20 (2009), pp. 265-297. See, also, M. Bothe, "The historical evolution of international humanitarian law, international human rights law, refugee law and international criminal law" in H. Fischer et al (eds), Krisensicherung und Humanitärer Schutz: Festschrift für Dieter Fleck, Berlin, BWV, 2004, p. 45: fragmentation "involves risks and opportunities."

2 See, in particular, M. Koskenniemi, Fragmentation of International Law: Difficulties Arising from the Diversification and Expansion of International Law. Report of the Study Group of the International Law Commission (2006).

3 See ECHR, McCann v. UK, Judgment of 27 Sept. 1995, Ser. A No. 324, \$\$ 146-50; Akhmadov v. Russia, Judgment of 14 Nov. 2008 (final 6 Jul. 2009), Appl. No. 21586/02, $\$ 92$ (in spite of its acknowledgment in $\$ 97$ that an armed conflict took place in Chechnya).

4 Supreme Court of Israel, Public Committee Against Torture v. Israel, Targeted Killings, HCJ 769/02, 11 Dec. 2005,46 ILM (2007) 375.

5 See Human Rights in Palestine and other Occupied Arab Territories, Report of the United Nations Fact Finding Mission on the Gaza Conflict, Human Rights Council, 12th session, 15 Sept. 2009, Doc. A/HRC/12/48 (advance edited version), paras 1715-33 et passim. 
a lex specialis that would block the application of other relevant bodies of law. Nevertheless, I do not think that it is impossible to find accommodation between the different rules and regimes in practice.

Of course, I also recognize the practical need for clarity. But to pretend that the normative expectations of the international community - a community that includes all international and some domestic actors, from the UN Security Council to the Israeli Supreme Court - could be limited to one single normative regime to the exclusion of all others would be illusionary. In the words of then-President Barak of the Israeli Supreme Court: "The normative system which applies (...) is complex." But this does not mean that it is impossible to bring some order into the applicable rules. In any case, the definition of the standards of behaviour should not be left in the hands of the operational commanders. Rather, they need legal guidance by their lawyers. This is the responsibility we need to fulfil, and I hope that this contribution will be helpful in this regard.

At first, I will deal with the different normative regimes arguably applicable to the use of force in occupied territories. I will then turn to the relationship of the regimes and try to give a tentative answer to the question: Which regime governs the use of force in occupied territory?

\section{NORMATIVE REGIMES APPLICABLE TO THE USE OF FORCE IN OCCUPIED TERRITORY}

While occupation presupposes, in the words of Article 2 of the Hague Regulations, "the authority of the hostile army" over territory "where such authority has been established and can be exercised," the use of military force appears to indicate that such control is absent. However, established authority and the occasional use of force are not contradictory, because occupation takes place in a zone of uncertainty, and in such a situation the establishment of $100 \%$ control appears almost impossible. The question then arises: Which law governs such violence?

Next to the 'law of occupation' as contained, in particular, in Articles 42 - 56 of the Hague Regulations and Articles $47-87$ of the Fourth Geneva Convention and the respective customary law, other potentially legal regimes applicable are the law on the conduct of hostilities, the law on the resort to military force, the jus ad bellum, and, most importantly, human rights law . We will discuss them in turn.

\section{INTERNATIONAL HUMANITARIAN LAW I: OCCUPATION LAW STRICTO SENSU}

The point of departure is to be found, in the law of occupation itself. Article 42 of the Hague Regulations, which applies pursuant to Article 154 of the Fourth Geneva Convention and customary law, provides, under the headline "Military Authority over the Territory of the Hostile State," that "[t]erritory is considered occupied when it is actually placed under the authority of the hostile army. The occupation extends only to the territory where such authority has been established and can be exercised." Article 2 common to the four Geneva Conventions (common Article 2) adds that "[t]he Convention shall also apply to all cases of partial or total occupation of the territory of a High Contracting Party, even if the said occupation meets with no armed resistance."

The latter point is not devoid of importance: for instance, while it is debatable whether the so-called transnational conflicts between States and non-State groups on the territory of another State fall under the rules of international or under those of non-international conflict, ${ }^{7}$ once an occupied power has established itself on the territory of another State, the law of international armed conflict becomes applicable. Of recent conflicts, this is valid, for instance, for the wars in Iraq and Lebanon.

\footnotetext{
Public Committee against Torture v. Israel (“Targeted Killings”), HCJ 769/02, 11 Dec. 2005, para. 18. I have deliberately omitted the passage in between that talks of "the armed conflict between Israel and the terrorist organizations in the area." On this matter, see, recently, A. Paulus and M. Vashakmadze, "Asymmetrical war and the notion of armed conflict: A tentative conceptualization," International Review of the Red Cross, Vol. 91, No. 873, March 2009, pp. 113-115.

7 On this matter, see Paulus and Vashakmadze, "Asymmetrical war and the notion of armed conflict," pp. 99-100 et passim.
} 
The matter is more complicated, however, with regard to the occupied territories and to the "Gaza war" of 2008/9. In the case of the Palestinian territories occupied by Israel, the International Court of Justice (ICJ), in its Wall Opinion, clarified that, while the occupied Palestinian territory may not belong to any other State, the occupation nevertheless falls under common Article 2, para. 1, because the territory was occupied in the wake of an armed conflict between High Contracting Parties, namely Israel and its neighbours. ${ }^{8}$ Whatever one otherwise thinks of the Advisory Opinion, this finding has been widely accepted, ${ }^{9}$ and while the Israeli government has, as far as I know, not formally changed its contrary position, it usually applies the Convention nevertheless, and the Israeli Supreme Court leaves the question open, but bases its decisions on the Fourth Geneva Convention, too; while the character of the Hague Regulations as binding customary law is not disputed by anyone. With regard to Gaza, the matter is much more complicated, because there is no agreement on the question whether Israeli control of airspace and border are sufficient to establish authority under the Hague Regulations. ${ }^{10}$

However, Gaza is only one example of the main problem with regard to the use of force in occupied territory: the question of whether occupation law is the only law applicable. If this were the case, the application of other rules, from those on the conduct of hostilities to self-defence under the jus ad bellum, would be excluded; any justification for the use of force would have to come from occupation law itself, in particular the provisions allowing for security exceptions to the obligations towards the occupied territory (such as Articles 5, $49 \$ 2$, $57 \S 1$, and 62 of the Fourth Geneva Convention, and Article 43 of the Hague Regulations). Of course, the question can be answered differently for each of the other bodies of law. For example, the ICJ has opined that human rights law is applicable to occupied territories, but the jus ad bellum is not. ${ }^{11}$ In general, occupation ends with the loss of control by the occupying power, ${ }^{12}$ which can also happen only in parts of the (formerly) occupied territory. ${ }^{13}$

It is possible to argue that either a territory is occupied, or it is in a state of 'hot' armed conflict so that the law on the conduct of hostilities is applicable. In an armed conflict, there is no control, and where there is control and thus occupation, there is no armed conflict. As Alexander Orakelashvili has put it,

"[t]he law of occupation applies to the areas over which the occupying power exercises effective control. It does not apply to situations where the adversary's army is still capable of fighting, thereby precluding the exclusive control of the would-be occupying power. Therefore, the situation in Palestine cannot be subjected to the law applicable to hostilities if it is governed by the law of belligerent occupation, because no territory can legally be the occupied territory and area of hostilities at the same time."14

Alas, in a situation of continued belligerent occupation and therefore belligerency, matters do not seem to be so clear-cut. First, it may be unclear whether or not sufficient authority exists for an occupation to continue. Gaza is a case in point. To adopt a strict view of the

8 Legal Consequences of the Construction of a Wall in the Occupied Palestinian Territory, Adv. Op., ICJ Rep. 2004, pp. 144-177, paras 95-101. See also H-P. Gasser in D. Fleck (ed.), The Handbook of International Humanitarian Law, 2nd ed., Oxford, Oxford University Press, 2000, p. 275, para. 527.

9 For the reaction of the Israeli Supreme Court, see Mara'abe v. Prime Minister of Israel, HCJ 7957/04, 15 Sept. 2005, para. 14 (noting the acceptance of the humanitarian provisions by the Government of Israel and leaving the question open). See also D. Kretzmer, "The advisory opinion: The light treatment of international humanitarian law," American Journal of International Law, 99 (2005), p. 90, with further references to the Israeli position in note 22.

10 Supreme Court of Israel, Jaber Al-Bassiouni v. Prime Minister, HCJ 9132/07, Judgment, 30 January 2008, para. 12; Yuval Shany, "The law applicable to non-occupied Gaza: A comment on Bassiouni v. Prime Minister of Israel," Hebrew University International Law Research Paper, No. 13-09, 2009, pp. 6-8, available at http://ssrn.com/abstract=1350307 (last visited 25 May 2009), on the one hand, and Y. Dinstein, The International Law of Belligerent Occupation, Cambridge, Cambridge University Press, 2009, paras 661-78, on the other.

11 Legal Consequences, paras 102-13 (applicability of human rights law), para. 139 (non-applicability of Article 51 of the United Nations Charter).

12 Art. 42 para. 2 of the Hague Regulations limits the applicability of occupation law to territory "where such authority has been established and can be exercised."

13 See only Dinstein, Belligerent Occupation, para. $657 \mathrm{ff}$.

14 A. Orakhelashvili, "The Interaction between human rights and humanitarian law: Fragmentation, conflict, parallelism, or convergence?" European Journal of International Law, 19 (2008), pp. 161-164. 
necessity of control for the beginning of an occupation may certainly render a strict separation between hostilities and post-hostilities occupation easier. On the other hand, such a view may lead to a certain reluctance to apply occupation law - in other words, it appears to run counter to the humanitarian purpose of extending its reach. It may thus "squeeze" occupation law between the rules for the conduct of hostilities and applicable human rights law. Thus, I would argue that occupation law needs a more broadly defined "trigger" than complete control. Accordingly, it should be sufficient for the establishment of 'authority' if the occupying power has established general control over the occupied territory (see Art. 42 of the Hague Regulations). In Armed Activities on the Territory of the Congo, the ICJ regarded the exclusion of the territorial State or any other authority as the main criterion for the establishment of the necessary authority by the occupying State, without determining a precise degree of control. ${ }^{15}$ But this also implies that occupation and the use of military force do not necessarily exclude each other. ${ }^{16}$ An American military tribunal seems to have held the same view in the Hostages case. ${ }^{17}$ The phenomenon of a "revolving door" in which control switches from day to night exemplifies such a situation.

\section{INTERNATIONAL HUMANITARIAN LAW II: CONDUCT OF HOSTILITIES}

Accordingly, the applicability of occupation law does not exclude the emergence of an armed conflict with regard to occupied territory. For the existence of such an armed conflict, the criteria of length and intensity should be applied - although the protractedness required by the International Criminal Tribunal for the former Yugoslavia (ICTY) and the Rome Statute indicate that a minimum extension in time is necessary to distinguish between jus in bello - armed conflict as situation - and use of force in self-defence. ${ }^{18} \mathrm{~A}$ certain indeterminacy in this regard appears unavoidable, however. A resort to military means by at least one side may be the best indicator for the existence of an armed conflict.

The problem remains whether conflicts within occupied territories are necessarily also international in character. While many authorities, such as the Israeli Supreme Court, hold this view, ${ }^{19}$ it is by no means a matter of course. ${ }^{20}$ In spite of the submissions of the prosecution to the contrary, the ICTY has held, in its Tadic Merits Appeal judgment, that each armed conflict needs to be analysed separately, and that it is possible for an internal conflict to exist alongside an international one. ${ }^{21}$ The same conclusion seems to follow from the Nicaragua judgment of the ICJ that distinguished between an international conflict between the United States and Nicaragua, on the one hand, and a non-international armed conflict between the armed group of the so-called contras and Nicaragua, on the other. ${ }^{22}$ The situation in the occupied Palestinian territory complicates the matter further because occupation law is applicable here as a consequence of an armed conflict (common Article 2 $\$ 1$ ) and not because of the occupation of the territory of a State Party as such (common Article $2 \$ 2$ ).

15 Armed Activities on the Territory of the Congo (Democratic Republic of the Congo v. Uganda), Judgment of 19 Dec. 2005, para. 173, available at www.icj-cij.org.

16 Similary, Dinstein, Belligerent Occupation, para. 234; F. Hampson, "The relationship between international humanitarian law and human rights law from the perspective of a human rights treaty body," International Review of the Red Cross, Vol. 90 , No. 871 , September 2008,549 at 554 , note 21

17 Hostages trial, (List et al.) (US Military Tribunal, Nuremberg, 1948), 8 LRTWC 34, 56, cited after Dinstein, Belligerent Occupation para. 101.

18 See C. Droege, "Elective affinities? Human rights and humanitarian law," International Review of the Red Cross, Vol. 90, No. 871, September 2008, 501 at 539, Paulus and Vashakmadze, "Asymmetrical war and the notion of armed conflict," at 107 118 (explaining that the temporal element is necessary because armed conflict is a situation, not a moment, and changes the applicable legal regime).

19 See Targeted Killings, para. 18; Physicians for Human Rights v. Israel, HCJ 201/09, Isr. Yb. Hum. Rts. 39 (2009) 406, 411 para. 13; A. Cassese, International Law, 2nd ed., Oxford, Oxford University Press, 2005 at 420; Dinstein, Belligerent Occupation, para. 232.

20 See, also, Question of the Violation of Human Rights in the Occupied Arab Territories, Including Palestine, Report of the human rights inquiry commission established pursuant UN Commission on Human Rights Resolution S-5/1 of 19 October 2000, Doc. E/CN.4/2001/121 (2001), para. 39.

21 ICTY, Prosecutor v. Tadić, Appeals Chamber Judgment (merits), 15 Jul. 1999, IT-94-1-A (Merits Appeal), available at www.icty. org, para. 84 (see the views of prosecution and trial chamber, $i d$. paras $85-86,88-89$ ).

22 ICJ, Nicaragua, para. 219. 
Yoram Dinstein has maintained that by the conclusion of the peace treaty between Israel and Jordan, ${ }^{23}$ the Palestinians became the "other party" to the conflict. ${ }^{24}$ This view is difficult to apply because it requires an analysis of the status of the groups involved that is inherently difficult and controversial - the very difficulty that IHL intends to avoid by establishing factual criteria for an armed conflict. Besides, it is unclear whether a renegade faction such as Hamas can be equated with the PLO as the internationally accepted representative of the Palestinian people, or with the Palestinian Authority to which Israel has devolved, in the Oslo Accords, ${ }^{25}$ some of its authority as occupying power. ${ }^{26}$ Rather, I would suggest identifying the relevant parties to every conflict in occupied territory separately. This would suggest that Israel's conflicts with Hamas and, more controversially, Palestinian elements in the West Bank were of a non-international nature, whereas an eventual conflict with the PLO - that is, the "official" representative of the Palestinian people - as a whole would be international. Be that as it may, it does not follow from this view that every armed conflict in the occupied Palestinian territory between the occupying power and the local population amounts to an international armed conflict. ${ }^{27}$ Article 1, para. 4, of Additional Protocol I suggests that, when the Protocol is applicable, "armed conflicts which peoples are fighting against colonial domination and alien occupation (...) in the exercise of their right of self-determination" fall also under international armed conflict, at least when the insurgents have made a respective declaration under Article $96 \$ 3$. This provision, one of the reasons why many States have not ratified Additional Protocol I, does not reflect customary international law. As to the occupied Palestinian territory, even if one might interpret the "ratification" of Additional Protocol I by the PLO as such a declaration, ${ }^{28}$ Israel is not bound by Additional Protocol I because it has not ratified it. This does not exclude, however, the application of those parts of the Protocol that are considered customary law.

Thus, there is a considerable argument according to which armed conflicts within an occupied territory need to be analysed in the same way as any other armed conflict and can be either international or non-international in character. However, in view of the rising convergence of the substantive rules for international and non-international conflicts, the impact of the international or non-international character of the conflict is limited. ${ }^{29}$ In each case, members of armed groups may attack only combatants, and civilians are not protected from attack while directly participating in hostilities. For the occupying power, the difference would be relevant only with regard to armed groups that claim to fulfil the criteria for combatants (Article $4 \mathrm{~A}$ of the Third Geneva Convention and Article 1 of the Hague Regulations); but in the absence of a High Contracting Party and of the applicability of Article $1 \S 4$ of Additional Protocol I, regular combat seems not to exist where acts are not attributable to any State.

Thus, it is in the humanitarian interest to continue to apply the law of occupation to the civilian population when armed conflict flares up in parts of the occupied territory, while

23 Treaty of Peace between the State of Israel and the Hashemite Kingdom of Jordan, 26 October 1994, 2042 UNTS 351, entry into force 10 Nov. 1994; for the Peace Treaty with Egypt, in which Gaza was left occupied, see Treaty of Peace between the Arab Republic of Egypt and the Government of the State of Israel, 26 March 1979, entry into force 25 April 1979, 1136 UNTS 115.

24 Dinstein, Belligerent Occupation, para. 122.

25 Israel-Palestine Liberation Organization, Declaration of Principles on Interim Self-Government Arrangements, 32 ILM 1525 (1993). For details, see Dinstein, Belligerent Occupation, paras 36-9 with references to the later accords.

26 See D. Kretzmer, “Targeted killing of suspected terrorists: Extra-judicial executions or legitimate means of defence?” European Journal of International Law, 16 (2005), 171 at 210. See Wall Op., Sep. Op. Kooijmans, ICJ Rep. 2004, p. 229-30, paras 35-36.

27 For the delineation between international and non-international armed conflict, see the discussion in Paulus and Vashakmadze, "Asymmetrical war and the notion of armed conflict," pp. 108-119.

28 Letter of 21 June 1989 from the Permanent Observer of Palestine to the United Nations Office in Geneva stating "that the Executive Committee of the Palestine Liberation Organization, entrusted with the functions of the Government of the State of Palestine by decision of the Palestine National Council, decided, on 4 May 1989, to adhere to the Four Geneva Conventions of 12 August 1949 and the two Protocols additional thereto," available at http://www.icrc.org/ihl.nsf/Pays?ReadForm\&c=PS (last visited 10 March 2009). This declaration was, however, probably an attempt at an ordinary ratification rather than a declaration under Art. $96 \$ 3$. For a further example of an attempt to invoke Article $96 \$ 3$, see NDFP Declaration of Undertaking to Apply the Geneva Conventions of 1949 and Protocol I of 1977, available at: www.hartford-hwp.com/archives/54a/036.html (last visited 10 March 2009).

29 M. N. Schmitt, 'Targeting and international humanitarian law in Afghanistan," Israel Yearbook on Human Rights, 39 (2009), 99 at 101: "[T]he IHL norms governing attacks during international armed conflicts, on one hand, and non-international armed conflicts, on the other, have become nearly indistinguishable." See also the submissions by the Government of Israel, in: Targeted Killings, para. 11; Y. Dinstein, 'Concluding remarks on terrorism and Afghanistan," Israel Yearbook on Human Rights, 39 (2009), 315 at 326-7, para. 31; Fleck in D. Fleck, Handbook of International Humanitarian Law, 2nd ed. Oxford, 2008, para. 1204 
in conflict with armed groups, the law on the conduct of hostilities applies. This does not imply, however, that the threshold for an armed conflict is a low one. Just the opposite: occupation law takes the legitimate security interests of the occupying power into account. Nevertheless, it appears unrealistic to expect a clear separation of zones of occupation and zones of hostilities. Indeed, the Fourth Geneva Convention (Articles 13 - 46) contains rules applicable to both situations.

\section{SELF-DEFENCE AND JUS AD BELLUM}

The distinction between jus ad bellum and jus in bello in international law does not need to be repeated. The one - controversial ${ }^{30}$ - exception in the Nuclear Weapons dispositive of the $\mathrm{ICJ}^{31}$ does not concern us here. However, the equally controversial passage in the Wall Opinion remains a central point of contention in this regard. According to the principal judicial organ of the United Nations, Article 51 of the United Nations Charter is not applicable to threats emanating from occupied territories. ${ }^{32}$ It is not the place here to analyse the problem in depth. ${ }^{33}$ However, it appears that matters have not remained there. While accepting the conclusions of the ICJ in general, the UN General Assembly has already reaffirmed, in Resolution 10/15 (2004), that:

"all States have the right and the duty to take actions in conformity with international law and international humanitarian law to counter deadly acts of violence against their civilian population in order to protect the lives of their citizens." ${ }^{34}$

This last-minute amendment paved the way for an overwhelmingly positive vote on the resolution, expressing the sense of many States that the right of States to defend their citizens might not have been adequately reflected in the Advisory Opinion. The ICJ itself left the question open in the next - contentious - proceeding dealing with the use of force, namely in its judgment in the Armed Activities on the Territory of the Congo case, while two Separate Opinions emphasized that they regarded the law as having evolved towards allowing selfdefence against non-State actors. ${ }^{35}$ I cannot but point out that I think that Judges Kooijmans and Simma are right, as were Judges Higgins, Buergenthal, and Owada in the Wall Opinion. I know of hardly any instance where a State has claimed that another must stand idle and 'show the other cheek' while it is attacked by military means, just because the source of that attack was not a State. This would hardly be compatible with the "natural" or "inherent" nature of the right to self-defence as contained in Article 51 of the UN Charter.

This result raises anew the question of the use of force within occupied territories. As the Separate Opinion of Judge Kooijmans in the Wall case shows, it does not follow from his position on the lawfulness of self-defence against non-State actors that he also holds the view that self-defence in occupied territory is permissible. ${ }^{36}$ I must confess that I have difficulty in following the reasoning of the ICJ, however. As Judge (later President) Higgins pointed out in her Separate Opinion, if an armed attack occurs from occupied territory rather than from another State, Article 51 does not contain anything removing the right to

30 See, e.g., Y. Dinstein, War, Aggression and Self-Defence, 4th ed., Cambridge, Cambridge University, 2005 at 16.

31 Legality of the Threat or Use of Nuclear Weapons, Adv. Op., ICJ Rep. 1996, 226, 263, para. 97, 226 (2) (e).

32 Wall Op., ICJ Rep. 2004, p. 194, para. 139; see also Sep. Op. Kooijmans, ICJ Rep. 2004, pp. 229-30, para. 36 (in accordance with this part of the proposition), but see Sep. Op. Higgins, p. 215 para. 34; Decl. Buergenthal, p. 243, para. 6.

33 For two different viewpoints, see, e.g., S. D. Murphy, "Self-defense and the Israeli Wall advisory opinion: An ipse dixit from the ICJ?" American Journal of International Law, 99 (2005), p. 62; I. Scobbie, "Words my mother never taught me: "In Defense of the International Court'," American Journal of International Law, 99 (2005), p. 76.

34 Advisory Opinion of the International Court of Justice Res. ES-10/15, 2. Aug. 2004, preambular para. 16. See also EU Presidency Statement - The ICJ-Resolution: Explanation of Vote (20 July 2004), cited by Scobbie, "In Defense of the International Court," p. 77, note 4, explicitly endorsing the view that Art. 51 was available under the circumstances.

35 Armed Activities on the Territory of the Congo (Democratic Republic of the Congo v. Uganda), Judgment of 19 Dec. 2005 , para. 147; Sep. Op. Kooijmans, para. 28; Sep. Op. Simma, para. 11; regarding Afghanistan, see S. D. Murphy, "The International legality of U.S. military cross-border operations from Afghanistan into Pakistan," Israel Yearbook on Human Rights, 39 (2009), 281 at 303 For a critique of the ICJ position, see Dinstein, War, Aggression and Self-Defence, p. 247 (however, using terminology - 'extraterritorial law enforcement' - that is open to confusion with the 'law enforcement-model' of anti-terrorist activity within States). For a brief analysis of recent practice, see Murphy, 'Self-defense and the Israeli Wall opinion,” pp. 67-70.

36 See Sep. Op. Kooijmans, op. cit., para. 36. 
self-defence of the attacked State, precisely because occupied territory does not belong to the occupying power but is separate from it.

But the reasoning of the ICJ appears incomplete, not necessarily incorrect. What it seems to imply is that as long as an occupation is firmly established, the law of occupation removes any claim under the jus ad bellum, also with regard to occupied territories. The ICJ emphasizes, in paragraph 139, that "Israel exercises control in the Occupied Palestinian Territory and (...) the threat which it [Israel] regards as justifying the construction of the wall originates within, and not outside, that territory." ${ }^{37}$ In other words, its view appears similar to those who argue that occupation and active hostilities mutually exclude each other.

But, for once, the reasons I gave above explaining why such a neat separation seems impossible sometimes with regard to the relationship between an occupation and hostilities, also apply to the question of self-defence: it is a separate argument whether or not an "armed attack" has occurred from occupied territory, and while I tend to think that the threshold for an armed attack is relatively high, it is not impossible for an armed attack to be waged from occupied territories otherwise under the authority of an occupying power. Particularly in "mixed" situations, in which the occupying power has given up some of its power and is then faced with an armed attack, such as in the current situation in Gaza, ${ }^{38}$ self-defence cannot be excluded. Whether the cumulative effect of several smaller attacks amounts to an armed attack is controversial, but should not be rejected a limine when there is an established connection between different attacks. ${ }^{39}$ As a matter of course, any response must meet the criteria for self-defence, in particular necessity and proportionality. ${ }^{40}$ The limitations of the jus in bello remain firmly in place, too, when a "protracted armed conflict" ensues.

\section{HUMAN RIGHTS}

The main area of overlap between legal systems regarding occupation is the application of international humanitarian law and human rights law at the same time. ${ }^{41}$ While the ICJ has emphasized, in its Nuclear Weapons Opinion, that human rights treaties remain applicable in armed conflict if and to the extent that they do not contain an exclusionary rule, international humanitarian law will be lex specialis with regard to the conduct of hostilities. Similarly, in its controversial judgment in the Banković case, the European Court of Human Rights has ruled that shooting at targets from the air is insufficient for establishing the necessary control to establish jurisdiction. ${ }^{42}$ In a situation of occupation, however, the ICJ has clarified, in its Wall Opinion, that human rights treaties remain perfectly applicable extraterritorially as soon as jurisdiction and control are established..$^{43}$ In addition, human rights law may be applicable by way of customary international law ${ }^{44}$ that does not limit its reach to the territory or jurisdiction of a particular State, while its applicability to non-State groups remains controversial..$^{45}$ Human rights law may also be applicable to occupied territories by reference in international humanitarian law or via general clauses contained therein or as part of applicable domestic law (as long as they are not contrary to the law of occupation).

37 For a more extensive analysis, see Scobbie, "In defense of the International Court," pp. 81-85.

38 On the current situation in Gaza, see Isr. Supreme Court, Jaber Al-Bassiouni Ahmed and others v. Prime Minister, Judgment of 28 Jan. 2008, HCJ 9132/07. para. 12; for critique, see Y. Shany, "Binary law meets complex reality: The occupation of Gaza debate (November 1, 2008)," Israel Law Review, 41 (2008), pp. 68-77 (arguing for an intermediate solution), Dinstein, Belligerent Occupation, paras 664-670 (regarding occupation as continuning).

39 See Murphy, “Cross-border operations into Pakistan," p. 301.

40 Legality of the Threat or Use of Nuclear Weapons, Adv. Op., ICJ Rep. 1996, 226, 245; Nicaragua, ICJ Rep. 1986, p. 94, para. 176; for an example from case law, see Oil Platforms, ICJ Rep. 2003, p. 161, 198, para. 76; see Murphy, "Cross-border operations into Pakistan."

41 For overviews, see Droege, “Elective affinities?'; A. Roberts, “Transformative military occupation: Applying the laws of war and human rights," American Journal of International Law, 100 (2006), pp. 590-601; see also M. J. Dennis, "Application of human rights treaties extraterritorially in times of armed conflict and military occupation," American Journal of International Law, 99 (2005), pp. 119-141.

42 Banković et al. v. Belgium et al., Admissibility, [2001-XII], ECHR, 333, paras 70-71.

43 Wall Opinion, ICJ Rep. 2004, p. 136, paras 106-13.

44 See Dinstein, Belligerent Occupation, para. 166. In this vein, see also U.S. Army Operational Handbook of 2008, Ch. 3, p. 39, available at http://www.au.af.mil/au/awc/awcgate/law/oplaw_hdbk.pdf; see also id., p. 44, denying the applicability of human rights treaties.

45 See A. Clapham, Human Rights Obligations of Non-State Actors, Oxford, Oxford University Press, 2006, pp. 272, 284. Clapham's functional approach suffers, however, from a certain lack of legal argument beyond the mere citation of practice. 
In spite of its considerable pedigree, the extraterritorial applicability of human rights treaties remains inherently problematic and controversial, in particular with regard to the conventions that constitute the so-called International Bill of Rights: the Covenants for Civil and Political and Economic, Social and Cultural Rights, respectively. ${ }^{46}$ Article 2, para. 1 of the International Covenant on Civil and Political Rights speaks of an undertaking of States Parties "to respect and to ensure to all individuals within its territory and subject to its jurisdiction the rights recognized in the present Covenant." While the wording suggests a cumulative reading requiring both territory and jurisdiction, ${ }^{47}$ the text also allows for a disjunctive reading that either territory or jurisdiction is sufficient to render the Covenant applicable. ${ }^{48}$

The latter view is held both by the ICJ in its Wall opinion and the Human Rights Committee under the International Covenant on Civil and Political Rights, ${ }^{49}$ and has also been accepted by some regional and domestic courts, such as the European Court of Human Rights (in the case of 'effective control of territory'), ${ }^{50}$ the Israeli Supreme Court (residually) $)^{51}$ and the UK House of Lords, ${ }^{52}$ albeit with some limitations derived from the relevant instruments and case law. It is the very purpose of human rights to fill gaps left by domestic law and to be applicable in situations where nothing else may be. ${ }^{53}$ The position taken by the international organs has thus met with broad approval, in spite of the resistance of the governments of some of the very States whose courts have accepted it. ${ }^{54}$ It is also in line with the derogation clauses of the respective treaties that do not imply any territorial restriction for the minimum obligations applicable in any case. However, the derogation clauses also point to a disadvantage of human rights law: the derogability of some or even most of its provisions in times of armed conflict (Articles 7 and 47 of the Fourth Geneva Convention). ${ }^{55}$

In any event, recent judicial and quasi-judicial practice has consistently held that human rights law is applicable extraterritorially to the extent that "jurisdiction" could be shown to exist. The jurisprudence of the European Court of Human Rights, which was taken up by the UK House of Lords and, to a certain extent, accepted by the UK government in Al-Skeini, ${ }^{56}$ is a case in point. Jurisdiction can be established either by territorial control - including, but not necessarily amounting to, military occupation - or, more controversially, by the exercise of authority or control over individuals by State agents. ${ }^{57}$ However, in line with the Banković judgment, ${ }^{58}$ this would exclude the application of human rights law on the battlefield.

46 International Covenant on Civil and Political Rights, GA Res. 2200A (XXI), 999 UNTS 171; International Covenant on Economic, Social and Cultural Rights, GA Res. 2200 A (XXI), 993 UNTS 3; Covenant on the Elimination of All Forms of Discrimination, GA Res. 34/180, 1249 UNTS 13; Covenant on the Rights of the Child, 1577 UNTS 3; Convention for the Protection of Human Rights and Fundamental Freedoms (ETS No. 5) 213 UNTS 222; African (Banjul) Charter on Human and Peoples' Rights, OAU Docs. CAB/LEG/67/3 rev. 5, 21 ILM 58 (1982); American Convention on Human Rights, O.A.S: Treaty Series No. 36, 1144 UNTS 123.

47 In this vein, Dennis, “Application of human rights treaties extraterritorially," p. 122 (relying on the drafting history); Dinstein, Belligerent Occupation, para. 163.

48 See Wall Opinion, ICJ Rep. 2004, p. 136, paras 109, 111, 112 (with regard to the International Covenant on Economic, Social and Cultural Rights that contains no relevant clause), 114 (with regard to the Convention on The Rights of the Child whose Article 2 speaks only of 'jurisdiction'); See also Armed Activities on the Territory of the Congo, paras 216-7; Human Rights Committee, General Comment No. 31, UN Doc. CCPR/C/21/Rev.1/Add.13, para. 10 (2004) (for the International Covenant on Civil and Political Rights); M. Nowak, U.N. Covenant on Civil and Political Rights: CCPR Commentary, 2nd ed., Kehl, N.P. Engel, 2005, Art. 2 paras 28-9.

49 See General Comment No. 31/80 of 29 March 2004, Nature of the General Legal Obligation Imposed on States Parties to the Covenant, CCPR/C/21/Rev.1/Add.13, 26 May 2004, paras 10-11.

50 Loizidou v. Turkey, (merits), [1996-VI] ECHR. 2216, at 2235-36, para. 56; Cyprus v. Turkey, [2001-V], ECHR., para. 77; for a broader view, see Issa v. Turkey, Appl. No. 31821/96, para. 69 ('effective control' as prerequisite for jurisdiction), 71 (responsibility for agents operating extraterritorially). See also M. Sassòli, "The international legal framework for stability operations: When may international forces attack or detain someone in Afghanistan?” Israel Yearbook on Human Rights, 39 (2009), 177.

51 Targeted Killings, paras 18, 40, (applying human rights at least residually).

52 Al-Skeini v. Secretary of State for Defence, [2007] UKHL 26, paras 79 (Lord Rodger of Earlsferry) (endorsing Banković), 83 (denying effective control in Basra).

53 See Sassòli, "The international legal framework for stability operations," p. 181, (while recognizing that the wording is tending towards the cumulative option, but referring to the object and purpose of human rights protection).

54 For the US and the Israeli positions, see Hampson, "Relationship between international humanitarian law and human rights law," p. 550.

55 Dinstein, Belligerent Occupation, para. 189

56 Al-Skeini et al. v. Secretary of State for Defence, [2007] UKHL 26, para. 3 (Lord Bingham of Cornhill).

57 Drozd and Janousek v. France and Spain, 26 June 1992, ECHR Ser. A, paras 91-96; Issa et al. v. Turkey, ECHR No. 31821/96, para. 71.

58 Banković et al. v. Belgium et al., Admissibility, [2001-XII], ECHR 333, paras 70-71; Alejandre v. Cuba, Inter-Am. Ct. H.R., Case 11.589, Rep. No. 86/99, OEA/Ser.L/V/II.106 Doc. 3 rev. at 586 (1999), para. 25. For criticism of the ECHR approach, see Hampson, "Relationship between international humanitarian law and human rights law," pp. 570-571. 
In Al-Skeini, the House of Lords understood the European Court of Human Rights as excluding the application of the Convention to situations of occupation beyond the territory of member States of the Council of Europe, e.g. in the words of the Court, the "legal space" of the Convention. ${ }^{59}$ (However, this judgment neither explains the most recent case law of the European Court of Human Rights, in which it applied the Convention to an extrajudicial killing by Turkish armed forces on Iraqi territory, ${ }^{60}$ nor deals with human rights law in general, especially treaties with a universal scope, such as the International Covenant on Civil and Political Rights. A better reading of the Strasbourg jurisprudence would appear to include, in line with the Appeals Court in Al-Skeini, ${ }^{61}$ situations of occupation by a State Party in the scope of the Convention, to the extent that the State in question has established control, just as in the other cases of extraterritorial jurisdiction. Whether or not the shooting of the five Iraqis in the case was covered by the Convention- and therefore whether the jurisdiction of the European Court of Human Rights was established - would accordingly be a matter of fact, not a question of applicable law.

Sassòli advocates a "functional" approach" towards the applicability of human rights law respecting the limits of extraterritorial authority and the sovereignty of the territorial State. ${ }^{62}$ The problem with this approach is its lack of clarity, which may well prevent its implementation in practice. As an alternative to such an 'opt-out' approach that applies all human rights in principle, it seems preferable to adopt an 'opt-in' approach that begins with the domestic law of the territorial State and includes its extraterritorial application when the jurisdiction of the State in question is positively established. This would include, however, situations of occupation when the conditions of Article 42 of the Hague Regulations are fulfilled, namely that the occupying power has successfully established its authority.

Thus, in situations of belligerent occupation, both international humanitarian law and human rights law apply cumulatively, in principle. Only in the exceptional case that both regimes arrive at different, mutually exclusive results, ${ }^{63}$ will it be necessary to decide for one of them on the basis of the usual legal principles, from the object and purpose of the two regimes to the lex specialis rule. In this respect, and in particular with regard to Social and Economic Rights, one should also keep in mind that many international human rights norms contain obligations of optimization of the enjoyment of the respective rights subject to considerations of proportionality, whereas the law of occupation consists of "stricter" norms demanding respect and application without considerations of feasibility or proportionality. In short-term occupations following the traditional model, the occupying power may thus be able to balance some of its human rights obligations with security needs, depending on the situation on the ground. However, when occupation lasts longer, and is stabilized, the occupying power must increasingly act like the government of a State. In this case, the relevant human rights instruments and the principle of proportionality require the full range of application of human rights law as in times of peace.

\footnotetext{
Banković, para. 80 .

See Issa, op. cit, paras 69, 71 .

61 Regina (Al-Skeini and others) v. Secretary of State for Defence [2007] Q.B. 140 at 282, paras 123-4 (Brooke LJ); id., p. 300, para. 197 (Sedley, LJ.): '[T]he one thing British troops did have control over, even in the labile situation described in the evidence, was their own use of lethal force." However, the latter view is incompatible with Banković, as LJ Sedley himself recognizes id., p. 301, para. 200.

62 Sassòli, "The international legal framework for stability operations," p. 183

63 According to M. Sassòli and L. M. Olson ("The relationship between international humanitarian and human rights law where it matters: Admissible killings and internment of fighters in non-international armed conflicts," International Review of the Red Cross, Vol. 90, No. 871, September 2008, 599 at 601), such conflict mainly concerns two areas: the permissibility of attacks against the members of armed groups when they do not participate in hostilities and the detention of captured members of armed groups without judicial review. Both are relevant to situations of occupation, too.
} 


\section{USE OF FORCE BY THE OCCUPYING POWER}

In the following, let me turn to the specific norms contained in the applicable regimes and look at their application to situations of occupation and at potential clashes between the applicable regimes.

\section{THE USE OF FORCE AND OCCUPATION LAW}

The main authority of the occupying power to restore and ensure public safety derives from Article 43 of the Hague Regulations that applies alongside the Fourth Geneva Convention according to Article 154 of this Convention and/or customary law. The Convention concretizes, in Article 27 et seq., and limits the power of the occupying power in this regard (see Articles $27,31,33,49,64,71,76,78$, etc.). Some of these provisions explicitly allow for exceptions for security measures of the occupying power (see, e.g., Articles $27 \$ 4$ and 78 of the Convention). In addition to these special provisions, Article 5 of the Convention provides for a general derogation for those protected persons "suspected of or engaged in activities hostile to the security of the State"; however, according to Article $5 \$ 3$, such persons "shall nevertheless be treated with humanity and, in case of trial, shall not be deprived of the rights of fair and regular trial."

While the Convention itself does not specify what it understands by 'humanity,' paragraph 3 makes it clear that the humanitarian provisions of the Convention apply, in principle, also to persons falling under Article 5. Article $5 \$ 2$ suggests that the main area of application is limiting communication with the outer world. ${ }^{64}$

Nowadays, courts seem reluctant to use Article 5 of the Fourth Geneva Convention to justify security measures, but would rather refer to more specific provisions of the Convention. For instance, the Israeli Supreme Court held Israeli internment law on the detention of "unlawful combatants" to be compatible with the Convention under Articles 42 and 43 on internment without direct reference to Article $5 .{ }^{65}$ But it is doubtful that any of these provisions give anything similar to a "licence to kill" rather than capture. In any event, Article 5 appears not to be applicable to armed groups or their members as such, but only to "individuals." Its application by analogy to members of armed groups appears questionable. ${ }^{6}$

In addition, Article 75 of Additional Protocol I, which is considered by most States to be an expression of customary international law independent of the nature of the conflict, ${ }^{67}$ contains a more concrete set of prohibitions mostly derived from human rights law.

\section{THE LAW ON THE CONDUCT OF HOSTILITIES,} IN PARTICULAR “TARGETED KILLINGS”

Membership in armed groups needs to be treated separately under the law on the conduct of hostilities, in particular Article 51, para. 3 of Additional Protocol I and Article 13 of Additional Protocol II. As the Nuclear Weapons Opinion of the ICJ suggests, international humanitarian law is lex specialis over human rights law. ${ }^{68}$ Likewise, the law on the conduct of hostilities supersedes the law of occupation because the latter presupposes control absent

64 In this regard, see also J. S. Pictet (ed.), The Geneva Conventions of 12 August 1949: Commentary, Geneva, International Committee of the Red Cross, 1952-58. p. 56.

65 Plonim v. Israel, Cr.A. (Criminal Appeal) 6659/06, 38 Israel Yb Hum. Rts. (2008) 295, 302, para. 20, 303, para. 24.

66 See Sassòli, “The international legal framework for stability operations,” pp. 197-198.

67 US Supreme Court, Hamdan v. Rumsfeld, 548 U.S. 557, 633, 126 S.Ct. 2749, 2797 (2006) (Stevens, J., plurality op.); ICJ, Armed Activities on the Territory of the Congo (Democratic Republic of the Congo v. Uganda), Sep. Op. Simma, paras 26-28, available at http://www.icj-cij.org/docket/files/116/10465.pdf (last visited 17 Feb. 2009); Council of Europe, Venice Commission of the European Commission for Democracy through Law, Opinion No. 245/2003, at its 57th Plenary Session, Venice, 12 13 December 2003, doc. No. CDL-AD (2003) 18, para. 38; UK Ministry of Defence (ed.), The Manual of the Law of Armed Conflict, Oxford, Oxford University Press, 2004, para. 9.2; see also the scepticism regarding Art. 75 of Additional Protocol I in Hamdan, 548 US 654, 126 S.Ct. 2809 (Kennedy, J. concurring; arguing that this was for the executive branch to decide) See also Arts 4 and 6 of Additional Protocol II extending the basic provisions of Article 75 of Additional Protocol I to noninternational armed conflicts.

68 Legality of the Threat or Use of Nuclear Weapons, Adv. Op., ICJ Rep. 1996, 226, at 240, para. 25. 
in hostilities. However, this does not exclude the continuing applicability of all provisions protecting civilians not directly participating in hostilities.

The most difficult point, however, concerns the status of members of non-State armed groups. They can be treated either as civilians directly participating in hostilities - with or without equating membership and direct participation - or as members of armed groups, which would result in their having the status of "quasi-combatants" unprotected by the rules safeguarding civilians. ${ }^{69}$ This debate relates to the law on the conduct of hostilities and is not at the core of this discussion.

However, the question remains relevant which law is applicable in case of a "new" armed conflict in occupied territory, as arguable in the Gaza case, or in "revolving door" situations in which control over territory changes from day to night. This depends on the question whether or not a "hot" armed conflict is taking place, and whether the acts of the armed group in question are attributable to a State. In case of an armed conflict, the rules of international or non-international armed conflict apply, e.g. combatants and civilians taking direct part in hostilities can be attacked.

As to the question of whether the law on the conduct of hostilities contains a rule requiring, if possible, the capture rather than the killing of a combatant, Practice Directive IX in the Interpretive Guidelines issued by the ICRC contains a requirement of necessity towards combatants, but has remained controversial, to say the least. ${ }^{70}$ According to the Martens Clause, there is no "unlimited freedom of choice of means in (...) weapons." "11 With regard to a situation in which armed conflict and occupation were allegedly both applicable, the Israeli Supreme Court applied an ostensibly domestic principle of proportionality to the practice of targeted killings and concluded that civilians taking a direct part in hostilities should be arrested whenever possible. ${ }^{72}$

However, if and to the extent a situation of armed conflict does not exist, "targeted killings" amount to "extrajudicial killings" unacceptable from a legal point of view. Only when the situation in parts of an occupied territory has crossed the threshold of armed conflict, does killing civilians taking a direct part in hostilities become permissible. Thus, the problem with the judgment of the Israeli Supreme Court in my view is not that it creates new rules on the conduct of hostilities drawn from human rights law, from whichever source, but that it blurs the distinction between a situation of hostilities and one of occupation. While there may be situations where both are present at the same time, this does not amount to permission for battlefield killings in the absence of an armed conflict. As long as a 'well-functioning law enforcement apparatus' exists, an armed conflict does not. In such a situation, targeted killings appear impermissible.

In most cases, a conflict between the regimes will not arise. As we intended to show, the overlap between the law of occupation and the law on the conduct of hostilities is limited. Complete control and hostilities do not sit well with each other. Only when an armed conflict takes place, however, is "shooting-to-kill" permissible under the laws of war. Nevertheless, conflict remains, for instance, with regard to targeted killings of members of an insurgent armed group such as the Taleban attending a secret meeting in Kabul. ${ }^{73}$ Governmental control would point to human rights law excluding targeted killings when an arrest is possible, the armed conflict-situation to a right-to-kill.

69 See Droege, "Elective affinities?" pp. 528-529; similarly Sassòli and Olson, "Relationship between international humanitarian law and human rights law where it matters," p. 607. In the latter regard, see Recommendations No. 1 and 2, Interpretive Guidance on the Notion of Direct Participation in Hostilities under International Humanitarian Law, Adopted by the Assembly of the ICRC on 26 Feb. 2009, International Review of the Red Cross, Vol. 90, No. 872, December 2008, 991, at 995.

1 Legality of the Threat of Use of Nuclear Weapons, ICJ Rep. 1996, p. 257, para. 78; see F. Kalshoven, Belligerent Reprisals, pp. 2056, who seems to contemplate a rudimentary principle of proportionality flowing from it; on the derivation of a principle of necessity from the Martens Clause and other rules of international humanitarian law, see N. Melzer, Targeted Killings in International Law, Oxford, Oxford University Press, 2008, pp. 278-99.

72 Targeted Killings, para. 40; Dinstein, Belligerent Occupation, para. 246

73 Sassòli, “The international legal framework for stability operations," p. 206 
Kretzmer and Sassòli regard the level of control as the decisive criterion. ${ }^{74}$ Accordingly, targeted killings would be permissible only if and to the extent the occupying power has largely lost control, such as in Gaza. In addition, Sassòli suggests that international humanitarian law and human rights law should inform each other as much as possible. ${ }^{75}$ Following the Targeted Killings judgment, ${ }^{76}$ this implies, for instance, conducting an independent investigation after every killing of an alleged fighter.

In my view, however, the example is one of non-exclusivity of the two regimes. Classic international humanitarian law does not prohibit an investigation; rather, it does not demand it. The only relevant question is whether the use of force is itself permissible: it is under international humanitarian law against civilians taking part in hostilities, but not in human rights law in the absence of a direct threat to life. The relevant distinguishing factor appears to be the existence vel non of an armed conflict. If so, international humanitarian law, if applicable, supersedes contrary (!) provisions of human rights law, i.e. allows for killing without a strict proportionality test or for using a looser standard towards the civilian losses incurred. ${ }^{77} \mathrm{On}$ the other hand, to the extent that the occupying power is in control of occupied territory and thus capable of making arrests, proportionality in human rights law requires arrest and allows for killings only in case of immediate danger to life and limb of another person. ${ }^{78}$

In non-international armed conflicts, strict symmetry between the obligations of armed forces and non-State groups may be difficult to achieve. However, I doubt that this question will be relevant in cases of occupation. It is regrettable that non-State groups are unlikely to conform to a great many rules of international humanitarian law. As long as the government controls the territory in question - in other words, as long as the territory is occupied - it appears entirely unrealistic to expect an "arrest-rather-than-kill" approach from non-State groups, in particular because they run into the danger of being regarded as kidnappers.

In any event, as Sassòli and Olson themselves admit, the practicality of flexible solutions is open to question. ${ }^{79}$ It will be the responsibility of the military leadership of the occupying power (and its lawyers) to determine in detail which rules of human rights law to apply in a given situation, subject to the review of domestic and international courts. The more a situation of occupation resembles ordinary government, the more the occupying power will have to follow the same rules as governments in peacetime. However, the more a belligerent occupation reverts back to hostilities, the more the relationship between the fighting forces will be governed by the lex specialis designed for such a situation, namely the law on the conduct of hostilities.

Nevertheless, it remains to be emphasized that as long as the government is in control of territory, occupation law and human rights law are the only applicable legal regimes. The law on the conduct of hostilities should be resorted to only in the presence of a "hot" armed conflict. However, in case one accepts that the required evidence is sufficient to justify a "targeted killing" and the occupying power is not sufficiently in control to apply human rights law in full, it appears nevertheless preferable to enrich international humanitarian law by elements of human rights law. Such a "mixed model" has been proposed by Kretzmer ${ }^{80}$ and, in substance, has been applied by the Israeli Supreme Court. ${ }^{81}$ But it remains to be emphasized that such "mixture" does not dispose of the requirement to ascertain whether the conditions for an armed conflict exist.

The present situation in the West Bank, for example, cannot be described as a "hot" armed conflict that would justify the use of force against alleged terrorists independently from the

74 D. Kretzmer, “Targeted killing of suspected terrorists: Extra-judicial executions or legitimate means of defence?' European Journal of International Law, 16 (2000), 171 at 203; Sassòli, “The international legal framework for stability operations," p. 206; Sassòli and Olson, "Relationship between international humanitarian law and human rights law where it matters," p. 614.

76 Targeted Killings, para. 40.

77 Droege, "Elective affinities?" p. 538: "Where hostilities continue or break out anew, humanitarian law on the conduct of hostilities must prevail over human rights law, which presupposes control for its enforcement."

78 See McCann, paras 146-50; Droege, “Elective affinities?” p. 538; Roberts, “Transformative military occupation,” p. 594.

79 Sassòli and Olson, "Relationship between international humanitarian law and human rights law where it matters," p. 616.

80 Kretzmer, “Targeted killing,” p. 203.

81 Targeted Killings, para. 40 
criteria of human rights law; whereas, during the Gaza war, it seems obvious that the law on hostilities applied to the relationship between Israel and Hamas, excluding the application of human rights law to terrorists or even the civilian population, which remained, in turn, protected by international humanitarian law. On the contrary, whether Basra was, after the coalition war against Iraq, in a situation of armed conflict or occupation, and whether the latter already allowed for the governance of territory in observance of human rights law, may be more doubtful. ${ }^{82}$

\section{HUMAN RIGHTS LAW}

The main difficulty relating to the questions to be discussed concerns the relationship between international humanitarian law and human rights law, to which an easy and clear solution is difficult to come by. As Marco Sassòli has put it: "The limited body of case law is (...) not really conclusive on the question as to what human rights law requires from government authorities using force against fighters, but there is no clear indication that the principles applicable in peacetime do not apply." ${ }^{\circledR 3}$ However, as Sassóli himself has shown, international as well as domestic cases in which fighters (or their relatives) claim to have been wrongly attacked are hard to come by. ${ }^{84}$

Some may argue that either international humanitarian law or human rights law always prevails in case of conflict. ${ }^{85}$ Yoram Dinstein has argued that international humanitarian law should, in general, prevail over human rights law:

"The extraordinary requirements of belligerent occupation strenuously put in doubt the practicality of subjecting it to ordinary human rights (...) Whatever their allure in general (...) they may too often be relegated to irrelevance under conditions of belligerent occupation. International law has no choice but to come up with lex specialis solutions. Only such solutions can be tailored to the specific challenges spawned in occupied territories." ${ }^{\$ 6}$

Others argue in favour of a cumulative approach. In the words of Gaggioli and Kolb:

"In times of armed conflict, human rights law applies simultaneously to international humanitarian law. The latter should not be considered as a lex specialis derogating from human rights law in its entirety. It should rather be considered as a complementary body of law allowing in many cases the strengthening of the general protections offered by human rights law." ${ }^{87}$

However, while such complementarity may be appropriate in cases where the two regimes are not contradictory, it does not provide a solution where the bodies of law diverge.

Finally, and most convincingly, many authors maintain that the relationship between the two bodies of law is complex and that every case needs to be analysed ad hoc, even at the price of lack of precision and clarity. In the words of Adam Roberts, "the precise relevance of human rights law in times of foreign military occupation needs to be carefully examined in any particular instance." ${ }^{\text {8 }}$ Thus, contrary to the US position, international humanitarian law is not a "general" lex specialis necessarily excluding the application of human rights

82 For the proposition that UK forces were not in a position to implement human rights obligations, see Al-Skeini, [2007] UKHL 26 (Lord Rodger of Earlsferry), para. 83; see also the Appeals Court in the same matter, op. cit.; and D. Campanelli, "The law of military occupation put to the test of human rights law," International Review of the Red Cross, Vol. 90, No. 871, September 2008, 653 at 665 (arguing that occupation necessarily implies control).

84 Sassòli and Olson, "Relationship between international humanitarian law and human rights law where it matters," p. 612.

85 See Hampson, 'Relationship between international humanitarian law and human rights law," pp. 559-61.

86 Dinstein, Belligerent Occupation, para. 690; see also Campanelli, “Law of military occupation," p. 656.

87 G. Gaggioli and R. Kolb, "A right to life in armed conflicts? The contribution of the European Court of Human Rights," Israel Yearbook on Human Rights, 37 (2007), 115 at 163.

88 Roberts, "Transformative military occupation," p. 599; similarly Sassòli, "The international legal framework for stability operations," pp. 204-6. 
law, but it is necessary to identify the lex specialis in every situation separately. ${ }^{89}$ Thus, where international humanitarian law is lex specialis - such as during "hot" armed conflict - human rights law is not applicable..$^{90}$ According to Sassòli, the relationship between international humanitarian law and human rights law may amount to a "sliding scale" where the "specificities of the situation" need to be taken into account. ${ }^{91}$ While this is certainly correct, such a pick-and-choose approach with regard to the applicable rules may blur the lines between armed conflict, occupation, and peacetime. It appears preferable to keep the regimes distinct as far as possible.

Thus, in a situation of belligerent occupation, but not "hot" armed conflict, international humanitarian law and human rights law complement each other. The occupying power may, of course, use the provisions of the Hague Regulations or of the Fourth Geneva Convention specific to situations of occupation, including those allowing for security measures, but, in addition, it needs to observe applicable human rights, both customary and conventional. However, the application of human rights law must take into account the specificities of occupation. In particular, those human rights that require a more long-term approach, such as social, economic and cultural rights, ${ }^{92}$ remain, of course, under the condition of the possible.

\section{CONCLUSION: INTERACTION OF INTERNATIONAL HUMANITARIAN LAW AND HUMAN RIGHTS LAW AND THE USE OF FORCE IN OCCUPIED TERRITORIES}

As Adam Roberts has suggested "the law of occupation remains both viable and useful, and has proved reasonably flexible in practice. ${ }^{\text {"9 }}$ The interrelationship of international humanitarian law and human rights law severely tests the flexibility and adaptability of occupation law.

This paper suggests the following provisional responses to the questions asked in paragraphs 2 and 3 of the introductory questionnaire:

The level of control is relevant to the question of the applicability of the law of occupation, the law on the conduct of hostilities, and, finally, to the proportionality analysis to be made under human rights law if applicable. Effective control and a well-functioning law enforcement regime exclude the applicability of norms on the use of force, whether under the jus ad bellum or under the law on the conduct of hostilities. However, the moment effectiveness wanes, an armed attack occurs, and armed conflict is renewed, those two branches of law become applicable again. In addition, the occupying power is obliged to apply human rights law if applicable, but human rights law needs to take account of the degree of control in the application of the proportionality principle and of the relativity of the optimization clauses in some human rights treaties.

In general, human rights law will be superseded by the law of occupation, including Article 43 of the Hague Regulations. If international humanitarian law is applicable - and this is a big "if" with regard to effective occupation - the standards of human rights law will, as a rule, not apply, but may inform the application of international humanitarian law regarding precautions and after-thefact investigations. Thus, international humanitarian law and human rights law may well complement each other, but their different conditions of applicability need to be strenuously observed. Otherwise, all sides are faced with an amalgam of norms that allow for arbitrary pick-and-choose approaches - in other words, that are in danger of not being applied at all.

9 P. Alston et al, "The competence of the UN Human Rights Council and its special procedures in relation to armed conflicts: Extra-judicial executions in the 'War on Terror'," European Journal of International Law, 19 (2008), 183 at 192; in the same vein, see Koskenniemi, Fragmentation of International Law , para. 96. (interpreting the ICJ Nuclear Weapons opinion, p. 240, para. 25)

90 Legal Consequences of the Construction of a Wall in the Occupied Palestinian Territory, Adv. Op., ICJ Rep. 2004, 136, at 144-177, paras 95-101; Nuclear Weapons, p. 240, para. 25. See also Sassòli, "The international legal framework for stability operations," p. 203; Droege, 'Elective affinities?' p. 539.

92 See Article 2, para. 1 of the International Covenant on Economic, Social and Cultural Rights.

93 Roberts, "Transformative military occupation," p. 580. 


\title{
AGENDA AND GUIDING QUESTIONS AIMED AT FRAMING THE DISCUSSIONS
}

\section{DAY ONE}

\author{
Working session 1: Delimiting the legal framework applicable \\ to the use of force in occupied territory
}

To what extent and under what conditions is the occupying power entitled to use force in occupied territory?

What are the legal regimes applicable to the use of force in occupied territory? Does occupation law make any assumptions about the legal regime governing the use of force in occupied territory? Is human rights law (HRL) the legal framework to be used as a matter of course in relation to the maintenance of public order and safety in occupied territory? To what extent must the occupying power comply with HRL standards on the use of force despite the general applicability of international humanitarian law (IHL), including the law governing the conduct of hostilities?

Does the level of control exercised in occupied territory affect the identification of the legal regime and its content? How can one evaluate the transition from the law enforcement model to the "conduct-ofhostilities' regime and vice versa? What are the rules applicable in "grey zones"? Is there any presumption of applicability of one regime over the other in such situations?

\section{Working session 2: The use of force to maintain public order and safety in occupied territory}

What does the maintenance of public order and safety mean for the purposes of IHL, in particular occupation law? Can the maintenance of public order and safety result in the application of IHL rules related to the conduct of hostilities? What are the permissible measures (and means/methods) that an occupying power may employ in order to maintain law and order in occupied territory?

Do the circumstances surrounding the use of force in occupied territory ("calm" occupation vs. occupation subject to armed resistance) determine the default legal regime? Do effective control and the presence of a well-functioning law enforcement apparatus necessarily lead to the precedence of the HRL regime?

What are the relevant legal instruments, provisions and principles in this respect? To what extent, if any, can/must the interpretation and application of the standards of necessity, proportionality and precaution underpinning the law enforcement model be adapted to the specific circumstances of belligerent occupation?

Are the conditions and procedures governing the resort to lethal force in exercise of the occupying power's law enforcement authority in occupied territory different (stricter or more relaxed) than those governing the territorial/domestic use of lethal force in peacetime?

\section{Working session 3: The use of force in activities related to the conduct of hostilities in occupied territory: Conditions for applying the 'conduct-of-hostilities' model}

In what circumstances is the use of force in occupied territory governed by the rules and principles of IHL on the conduct of hostilities?

Does one need to see proof of a resumption of large-scale hostilities in order to apply the 'conduct-ofhostilities' model? If yes, when can it be said that hostilities have broken out anew? What if hostilities are only sporadic? Is the applicability of the 'conduct-of-hostilities' model geographically and temporally limited? 
Can the occupying power, on its own initiative, trigger the applicability of the 'conduct-of-hostilities' model during a "calm" occupation?

To what extent, if any, can/must the interpretation and application of the general rules governing the conduct of hostilities in international armed conflict be adapted to the specific circumstances prevailing in occupied territory?

Working session 4: The use of force in activities related to the conduct of hostilities in occupied territory: Limitations of the 'conduct-of-hostilities' model

Is the use of lethal force in occupied territory against members of organized resistance movements automatically lawful or subject to certain conditions?

In particular, is there an obligation to capture rather than kill the enemy in occupied territory? If the obligation to capture rather than kill is accepted, what are the conditions for its implementation? In other words, to what extent does the risk incurred by the occupying forces through an attempt to capture rather than kill enter the equation? How does the existence of effective control affect this concept of "capture rather than kill" during the conduct of hostilities in occupied territory?

Can the occupying power's general responsibility for the welfare of the population under occupation influence its ability to conduct hostilities in occupied territory?

\section{DAY TWO}

\section{Working session 5: The interaction between the law enforcement and 'conduct-of-hostilities' models in occupied territory}

What is the relevant legal regime governing an operation that is both a police operation against an individual violating the laws in force in occupied territory (including measures promulgated by the occupying power) and a military operation against a legitimate military target under IHL? In this regard, how can one concretely distinguish between policing functions and combat activities in occupied territory? How does the occupying power's right to ensure its own security relate to its obligation to maintain law and order in occupied territory?

What is the legal framework when the law enforcement and 'conduct-of-hostilities' models overlap? In such situations, would it be useful to resort to an approach blending these legal regimes? What are the merits and potential challenges of such blended approaches to controlling the use of force in occupied territory? In the light of the Israeli Supreme Court's "targeted killing" case, can it be said that the HRL regime may be used in occupied territory to reduce the occupying power's freedom to act under IHL?

Does the 'conduct-of-hostilities' model always prevail in situations of overlap as a matter of lex specialis? How can we reconcile law enforcement standards on the use of force with the fact that occupation, as a sub-category of international armed conflict, permits the use of force under IHL governing the conduct of hostilities? Can armed resistance against the occupying power be treated as a matter of law enforcement?

\section{Working session 6: The interaction between the law enforcement and 'conduct-of-hostilities' models in occupied territory (continued)}

What is the legal regime applicable to "undercover operations" in occupied territory? Can a police operation suddenly turn into a military one and vice versa? If so, under what circumstances? What would be the legal framework of reference for such a sequence of actions? Does the prohibition against perfidy under IHL mean that the occupying power cannot resort to undercover operations aimed at capturing, injuring or killing members of organized armed groups in occupied territory? 


\section{APPENDIX 3 \\ LIST OF PARTICIPANTS}

1. Prof. G. Abi-Saab, Graduate Institute of International and Development Studies, Geneva

2. Prof. P.G. Alston, New York University/Special Rapporteur of United Nations

3. Prof. J. Cerone, New England School of Law

4. Prof. L. Doswald Beck, Graduate Institute of International and Development Studies, Geneva/ Geneva Academy of International Humanitarian Law and Human Rights, Geneva

5. Prof. R. Kolb, University of Geneva

6. Dr N. Lubell, Irish Centre for Human Rights, National University of Ireland, Galway

7. Dr B. Oswald, University of Melbourne

8. Prof. A. Paulus, Georg-August University of Göttingen

9. Prof. A. Roberts, University of Oxford

10. Prof. M. Sassolì, University of Geneva

11. Dr I. Seiderman, Senior Legal and Policy Adviser, International Commission of Jurists, Geneva

12. Col D. O. Stewart, Director of the Military Department, International Institute of Humanitarian Law, San Remo

13. Brig. Gen. K. Watkin, Judge Advocate General, Ministry of Defence, Canada

14. Dr M. Zwanenburg, Senior Legal Adviser, Ministry of Defence, The Netherlands

15. Prof. Y. Sandoz, Geneva Academy of International Humanitarian Law and Human Rights, Member of the ICRC

16. Dr P. Spoerri, Director for International Law and Cooperation within the Movement, ICRC

17. Mr L. Colassis, Deputy Head of the Legal Division, ICRC

18. Dr J.F. Queguiner, Head of Unit, Legal Division, ICRC

19. Ms. J. Pejic, Legal Adviser, ICRC

20. Dr S. Vité, Legal Adviser, ICRC

21. Dr T. Ferraro, Legal Adviser, ICRC 


\section{MISSION}

The International Committee of the Red Cross (ICRC) is an impartial, neutral and independent organization whose exclusively humanitarian mission is to protect the lives and dignity of victims of armed conflict and other situations of violence and to provide them with assistance. The ICRC also endeavours to prevent suffering by promoting and strengthening humanitarian law and universal humanitarian principles. Established in 1863, the ICRC is at the origin of the Geneva Conventions and the International Red Cross and Red Crescent Movement. It directs and coordinates the international activities conducted by the Movement in armed conflicts and other situations of violence. 
总 